
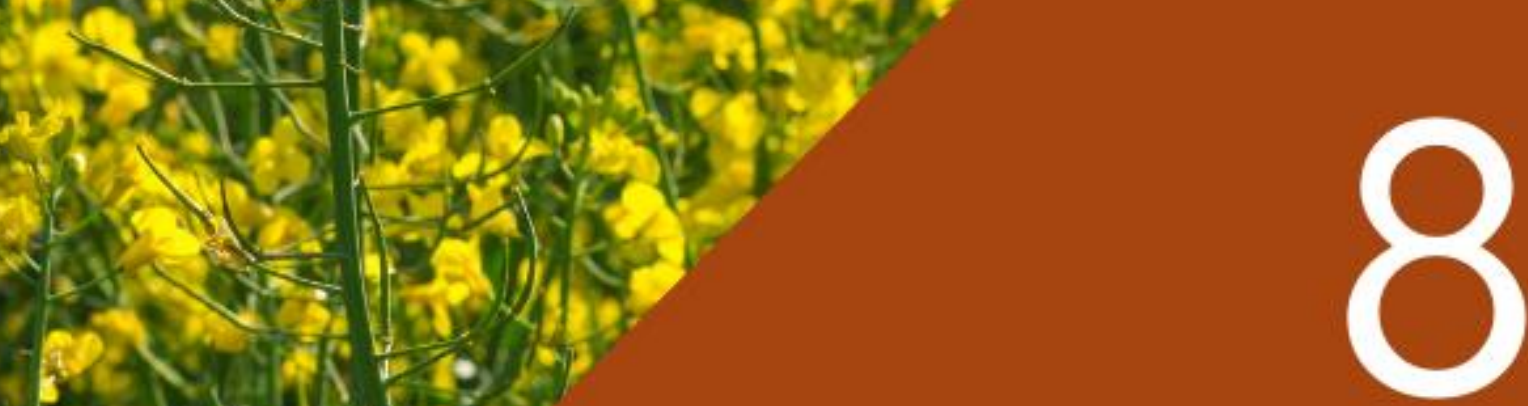

Fabiane dos Santos Toledo

(Organizadora)

Editora Poisson

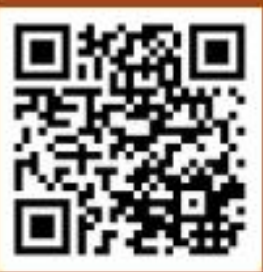


Fabiane dos Santos Toledo

(Organizadora)

\title{
Meio Ambiente em Foco Volume 8
}

\author{
1a Edição
}

Belo Horizonte

Poisson

2019 
Editor Chefe: Dr. Darly Fernando Andrade

\section{Conselho Editorial}

Dr. Antônio Artur de Souza - Universidade Federal de Minas Gerais

Ms. Davilson Eduardo Andrade

Dr. José Eduardo Ferreira Lopes - Universidade Federal de Uberlândia

Dr. Otaviano Francisco Neves - Pontifícia Universidade Católica de Minas Gerais

Dr. Luiz Cláudio de Lima - Universidade FUMEC

Dr. Nelson Ferreira Filho - Faculdades Kennedy

Ms. Valdiney Alves de Oliveira - Universidade Federal de Uberlândia

Dados Internacionais de Catalogação na Publicação (CIP)

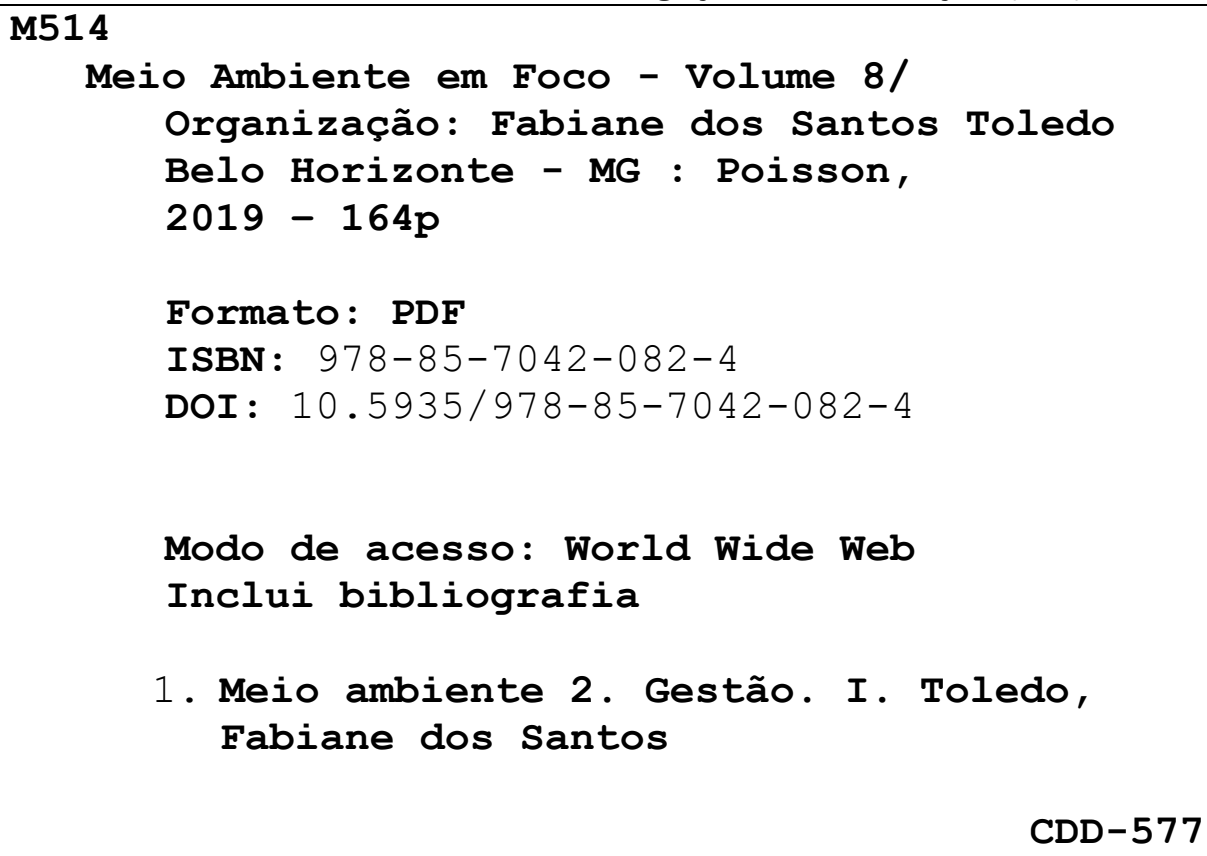

1. Meio ambiente 2. Gestão. I. Toledo, Fabiane dos Santos

O conteúdo dos artigos e seus dados em sua forma, correção e confiabilidade são de responsabilidade exclusiva dos seus respectivos autores.

Baixe outros títulos gratuitamente em www.poisson.com.br 


\section{APRESENTAÇÃO}

Há uma exigência imperiosa em ligarmos as relações humanas com as bases da sustentabilidade para a vida em nosso planeta. Ressignificar, no sentido de atribuir o que se conhece à nossa visão sobre o meio do qual somos integrantes, é um dos caminhos para a percepção ambiental mais eficiente e ativa em prol da educação e da qualidade de vida que constitui a essência de qualquer ser vivo. Para tal, requer-se mudar as perspectivas e alterar os resultados, além das escolhas e dos comportamentos.

Formar entendimento e conectar o ser humano com o meio ambiente apazigua e restaura os valores, as escolhas e as atitudes ambientais, transformando a sociedade e a cultura além das necessidades. É com esse viés que se pode chegar à tomada de consciência e às mudanças significativas

Ao ampliarmos os conhecimentos e levá-los adiante cumprimos com o desafio de coordenar a riqueza ambiental do país de forma mais equitativa e descentralizada, assegurando a reflexão e o debate com justiça socioambiental. Desenvolvendo, portanto, a clareza do papel de cada um nesse processo.

Alinhar ao que o caro leitor espera, surpreendê-lo e estimulá-lo a compartilhar com o maior número de pessoas, desde estudantes, profissionais, a tomadores de decisões, se propaga nas próximas páginas, recheadas de bons conteúdos, comprometimento dos autores e amplas vias de conhecimento.

Aproveite a leitura!

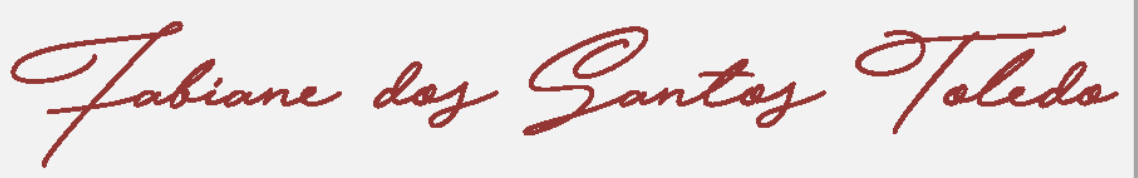




\section{Sumárīo}

Capítulo 1: Disposição final dos resíduos sólidos do município de Jacaraci - Bahia... 08 Adeid Rodrigues Santos Silva, Aline Aguiar Dourado, Andresa Sampaio Santos Soares, Ronny da Silva Duarte, Tácio Luís de Andrade Conceição

Capítulo 2: Análise da gestão e gerenciamento dos Resíduos de Serviços de Saúde (RSS) e seus impactos ambientais: Uma revisão bibliográfica

Graciete da Silva Figueiredo, Ricardo Jorge Amorim de Deus, Simonny do Carmo Simões R. de Deus, Roberto Carlos Figueiredo

Capítulo 3: Programa de gestão de resíduos - Poli USP Recicla

Welson Gonçalves Barbosa Junior, Pedro Paulo Consul Kassardjian, José Carlos Mierzwa

Capítulo 4: Descarte de óleo de cozinha no Ponto de Entrega Voluntário (PEV) da lagoa do Japiim:Diagnóstico de educação ambiental.

Nelcinda Cleto Fernandes, Itaní Sampaio de Oliveira, Cláudio Nahum Alves

Capítulo 5: Oxidação fotocatalítica de etileno: Uma estratégia para a redução do descarte de frutas e hortaliças

Alex Basso, Regina de Fátima Peralta Muniz Moreira, Humberto Jorge José

Capítulo 6: Avaliação da adsorção do corante azul reativo Ci 222 com adsorvente de resíduo sólido industrial seco e ativado quimicamente com $\mathrm{H}_{2} \mathrm{SO}_{4}$

Gabrieli Coelho de Souza Heimoski Ribeiro, Catia Rosana Lange de Aguiar

Capítulo 7: Estimativa de captação da água de chuva do telhado do campus da Faculdade Santo Agostinho em Vitória da Conquista - BA.

Álvaro Magalhães Lessa, Emanuelle dos Santos Lemos, Paulo Sérgio Monteiro Mascarenhas

Capítulo 8: Percepção ambiental hídrica: Eirunepé na calha do Rio Juruá, Amazonas

Delsinei Vieira da Costa, Carlos Henrique Rodrigues Gomes, Katia Viana Cavalcante, Valdiney Ferreira de Almeida, William Vieira de Lima

Capítulo 9: Usos múltiplos dos recursos hídricos em propriedade rural na Bacia Hidrográfica do Rio Tarumã-Açu, Manaus - AM

Solange Batista Damasceno, Elton Alves de Souza Filho, Samara Beatriz da Silva Mendonça Alves 


\section{Sumárīo}

Capítulo 10: Análise de parâmetros microbiológicos da água da represa Jurumirim, Avaré - SP

Bruna Maria da Silva Hamano, Yara Laureano Francisco, Camila Ferreira Bannwart Castro, Mariana Morena de Vieira Santos Greatti, Adrielli Cristina Peres da Silva, Igor Otavio Minatel, Viviane Mattos Pascotto

Capítulo 11: Degradação ambiental do Rio Araçuaí do ponto de vista da memória local 60

Andréia Galvão Soares, Edilson Luiz Cândido

Capítulo 12: Distribuição espacial de doenças relacionadas as condições sanitárias nos bairros Leader e missão em Jacobina Bahia. 68

Renato Alves Ferreira de Jesus, Philipe Souza da Silva, José da Silva Junior, Natafia Deize Nascimento Passos, Débora Rosa Miranda, Marcus Vinicius Silva Santos

Capítulo 13: A saúde como direito de cidadania e a questão das populações tradicionais em áreas ambientalmente protegidas

Rodrigo Ceregatti Franco, Cindy Carolina Benedetti Fedocci, Lucas Pereira da Silva Freitas, Duarcides Ferreira Mariosa

Capítulo 14: Comparação entre métodos para identificação de larvas de geohelmintos na Baía do Pontal, Ilhéus, Bahia. 82

Geovanna Carvalho Cardoso Lima, Marcelo Fernandes da Silva

Capítulo 15: Uma contribuição na análise de viabilidade econômica, social e ambiental no uso do lodo de esgoto na agricultura do Distrito Federal. 87

Marcos de Lara Maia, Gustavo Macedo de Melo Baptista

Capítulo 16: A energia solar fotovoltaica no programa Minha Casa Minha Vida 94

Dione Vitor dos Santos

Capítulo 17: Custos de implantação de uma horta caseira . 102 


\section{Sumário}

Capítulo 18: A leitura em espaços não formais como estratégia pedagógica na educação ambiental*. 108

Quemuel Alves da Silva, José Cavalcante Lacerda Junior, Evelyn Lauria Noronha, Maria Inês Gasparetto Higuchi

Capítulo 19: Interdisciplinaridade no saber: uma proposta de educação e cidadania

Maiara de Souza Nunes Ávila, André Niedersberg de Ávila, Michele Pantoja Duque;, Suziane Araújo Amorim, Aderlany Laranjeira, Jorney Moreira Barbosa

Capítulo 20: Análise dos fragmentos florestais remanescentes em uma paisagem com cultivo de dendê, na bacia hidrográfica do Rio Moju - Amazônia

Thais Gleice Martins Braga, João Ubiratan Moreira dos Santos, Maria de Nazaré Martins Maciel, Paula Fernanda Viegas Pinheiro, Orleno Marques da Silva Junior

Capítulo 21: Arborização do IFMT - campus cuiabá bela vista: Utilizando espécies nativas com potencial para sistemas agroflorestais

Fabiana Farias de Araújo, Gabriele Vitória Queiroz da Costa, Adaiane Catarina Marcondes Jacobina

Capítulo 22: Estoque de C do solo sob cultivo do feijão-caupi em sistema de plantio direto no brejo paraibano

Mary Anne Barbosa de Carvalho, Ewerton da Silva Barbosa, Adailson Pereira de Souza, Helton de Souza Silva, Valeria Borges da Silva, Maria Idaline Pessoa Cavalcanti

Autores: 


\section{Capítulo 1}

Disposição final dos resíduos sólidos do município de Jacaraci - Bahia

\section{Adeid Rodrigues Santos Silva \\ Aline Aguiar Dourado \\ Andresa Sampaio Santos Soares \\ Ronny da Silva Duarte \\ Tácio Luís de Andrade Conceição}

Resumo: 0 resíduo é um dos mais sérios problemas sanitários e ambientais do mundo moderno, visto que sua disposição inadequada causa prejuízos ao meio ambiente. Nesse sentido, este trabalho pretende analisar os impactos da disposição final dos resíduos sólidos urbanos (RSU) do município de Jacaraci - Bahia, destacando a importância da educação ambiental como ferramenta para minimizar as agressões causadas por eles. Para tanto, foi feito um estudo da rotina do lixão municipal, bem como um levantamento bibliográfico do tema abordado, cujos resultados mostraram que os resíduos sólidos urbanos coletados são postos a céu aberto, sem qualquer tipo de tratamento, o que tem ocasionado poluição visual, proliferação de vetores, contaminação do solo, do lençol freático e, também, devido à localização do lixão, a nascente situada no "banheirão" sofre com o chorume, que em períodos de chuvas é escoado. Dessarte, para evitar os danos provocados pela forma inadequada de se depositar o resíduo, a educação ambiental pode ser utilizada e aplicada por toda a população em escolas, empresas e em casa.

Palavras-chave: Resíduo. Poluição. Educação Ambiental. Lixão. 


\section{INTRODUÇÃO}

O Resíduo é um dos mais sérios problemas sanitários e ambientais do mundo moderno. No Brasil, de todos os segmentos que formam o setor de saneamento, essa é a área que sofre com maior intensidade, por não ser priorizada pelas autoridades. Pelo fato de quase $90 \%$ dos detritos serem jogados a céu aberto, há uma dificuldade no controle de epidemias, uma vez que os lixões fornecem condições propícias para a proliferação de vetores de doenças, como moscas, baratas e ratos. 0 dano ambiental também é grande, já que, além da liberação de gases, a decomposição do lixo gera o chorume, líquido que contamina o solo, o ar e os recursos hídricos (RESENDE e VIEIRA, 2004).

É comum definir resíduos sólidos como todo e qualquer resto que provém das atividades diárias do homem na sociedade (LIMA, 2001). Schneider et al (2004) ampliam o conceito, relacionando-o a tudo que é gerado como consequência não desejada de uma atividade humana e, em geral, de qualquer ser vivo, sendo assim, pode-se dizer que os detritos são advindos das ações do ser humano e dos animais domésticos.

Entre as formas de destino ou tratamento mais usuais no Brasil, o acúmulo de resíduos nos lixões é o método que aparece em primeiro lugar, dado vez que esses são jogados a céu aberto em terrenos próximos às áreas urbanas, não havendo a separação por tipo de material ou composição química, favorecendo a precariedade no acondicionamento e a contaminação do ambiente e de pessoas e animais que frequentam o local; o segundo lugar é ocupado pelo método de reciclagem, que é o processo de separação do lixo antes do destino final, havendo a reutilização e redução do que for possível, dessa forma, diminui-se a pressão sobre os aterros sanitários ou outros tipos de destino final; o condicionamento em aterro sanitário é o terceiro método mais encontrado, caracterizado pela deposição controlada de resíduos sólidos no solo e sua posterior cobertura diária, promovendo, assim, desde a degradação natural por via biológica até a mineração da matéria biodegradável, em condição fundamentalmente anaeróbia; por fim, em quarto lugar, está o método de incineração, que é a queima do resíduo transformando-o em cinzas, sendo bastante viável para os casos de lixo hospitalar ou resíduo contaminado (FRANÇA e RUARO 2009).

A destinação final do lixo deve estar vinculada diretamente à preservação do meio ambiente e, para isso, a aplicação da educação ambiental é uma das formas de fazer a humanidade perceber que o tratamento adequado dos resíduos sólidos constitui-se como um dos fundamentos da qualidade ambiental, quando observado que o desequilíbrio do ecossistema é agravado pelo crescimento populacional e o intenso processo de urbanização, aliado ao consumo exagerado dos recursos naturais (FRANÇA e RUARO, 2009).

Toda a sociedade deve exigir dos governantes o despejo correto do resíduo em aterros sanitários com o objetivo de minimizar os danos ambientais e sanitários. Porém, a população, em geral, limita-se apenas a exigir a coleta de lixo, sem se importar com o seu destino final e com as consequências ambientais que possam ocorrer. Isso acontece porque poucas pessoas estão diretamente incomodadas ao se dar um destino adequado aos resíduos (NÓBREGA e CARVALHO, 2002).

Considerando o fato de que a disposição inadequada de toda e qualquer sujeira no meio ambiente é um problema em quase todos os municípios brasileiros e que o município de Jacaraci - BA se encontra nessa situação, o presente trabalho propõe realizar uma análise dos impactos socioambientais que envolvem tal questão na área urbana do município, bem como, destacar a importância da educação ambiental como instrumento para minimizar os impactos desse ato.

\section{MATERIAL E MÉTODOS}

O município de Jacaraci situa-se no sudeste do estado da Bahia (Figura 1), caracterizado pelo domínio das chapadas e serras, ocupando uma área de $1.332,420 \mathrm{~km} 2$. A população estimada pelo Instituto Brasileiro de Geografia e Estatística (IBGE), em 2010, é de 13651 habitantes. 
Figura 1: Localização do município de Jacaraci.

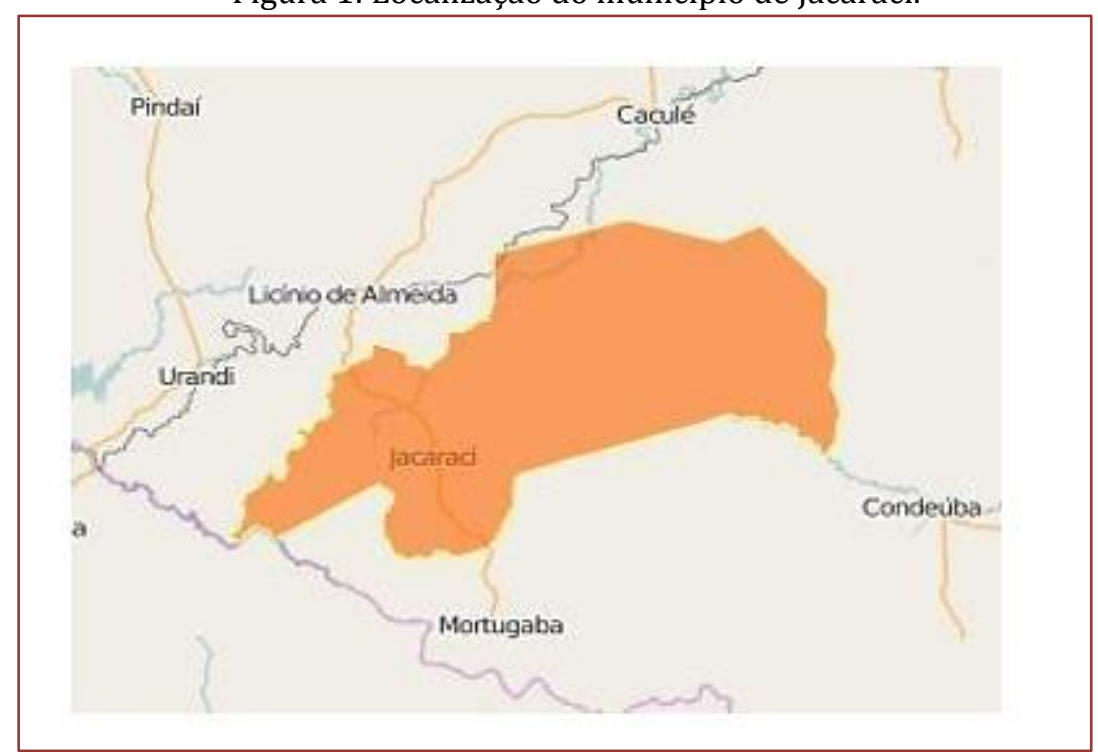

Fonte: IBGE.

A coleta de dados foi realizada no período de fevereiro a março de 2016, por meio de visitas in loco no lixão do município, bem como por meio de pesquisa bibliográfica sobre os problemas que envolvem a disposição inadequada de resíduos sólidos urbanos (RSU). Nessa cidade, a gestão dos RSU é realizada exclusivamente pelo poder público municipal sob a coordenação do Departamento Municipal de Limpeza Urbana.

O lixão de Jacaraci tem $1000 \mathrm{~m}^{2}$ de extensão e sua capacidade para a recepção de resíduos é em média $245718 \mathrm{~kg}$ por mês. Em suas proximidades encontram-se fazendas, sítios e córregos, sendo que foram seguidos os critérios básicos de distância mínima de 300 metros de cursos d'água, de 100 metros de rodovias e estradas e de 500 metros de quaisquer núcleos populacionais.

No período, 17 funcionários da prefeitura de Jacaraci estiveram envolvidos diretamente no sistema de coleta e transporte de lixo, realizado diariamente por garis com caminhões que passam de porta em porta.

A análise das condições do lixão em estudo foi realizada seguindo a metodologia proposta por FRANÇA e RUARO (2009), com modificações, por meio da observação dos seguintes parâmetros:

a) Existência de cercas, cuja função principal é inviabilizar a passagem e a presença de pessoas e animais no local;

b) Proximidades com águas superficiais, levando-se em consideração os agravos da contaminação da água subterrânea e superficial por chorume;

c) Coleta e tratamento de chorume e do biogás, importantes fatores que contribuem para a contaminação do meio ambiente;

d) Presença de catadores ou animais, os quais têm relação direta com a saúde pública na transmissão de doenças.

\section{RESULTADOS E DISCUSSÃO}

Após a análise do despejo dos RSU no município de Jacaraci - BA, notou-se que estes, sendo de diversas origens e natureza, são lançados sem qualquer tipo de controle e depositados pelos caminhões da prefeitura sobre o solo na forma de pilhas. Nessas pilhas foram encontradas sucatas, pneus, produtos eletrônicos, móveis, eletrodomésticos velhos, materiais de origem hospitalar.

O lixão utilizado para destinação final de RSU, que fica a apenas $2 \mathrm{~km}$ do perímetro urbano, possui uma área de livre acesso. Assim sendo, não há um controle de entrada de pessoas e muito menos orientação acerca dos riscos oferecidos pelo local, favorecendo a contaminação biológica ou química através do contato com os resíduos. 
A disposição de RSU de forma descontrolada em lixões é extremamente preocupante, visto que os resíduos a céu aberto geram significativa poluição ambiental e atraem inúmeros vetores de doenças, sendo estes divididos em dois grandes grupos de seres vivos: os macro-vetores (moscas, baratas, ratos, cachorros, urubus) e os microvetores (bactérias, fungos e vírus), que são responsáveis pela transmissão de doenças como leptospirose, dengue, diarreia, febre tifoide, entre outras (PEREIRA \& MELO, 2008).

A cidade de Jacaraci não possui nenhum programa de coleta seletiva. No entanto, verificou-se o interesse do poder público municipal pela instalação desse sistema. Atualmente, os RSU coletados são misturados e jogados no lixão, impedindo a reutilização de materiais que poderiam ser reciclados. Com a implantação da coleta, a cidade contribui com a geração de renda mediante as cooperativas de reciclagem, além de reduzir a quantidade de resíduos que são dispostos no lixão, causando menor impacto ambiental.

Foi observada a presença de material queimado no local, indicando a prática corriqueira da queima do resíduo, principalmente os hospitalares, com o intuito de diminuir o volume dos restos depositados, contudo, essa é uma prática incorreta, conforme a resolução CONAMA 358 de 29 de abril de 2005 (Figura 2).

Figura 2: Material queimado no lixão.

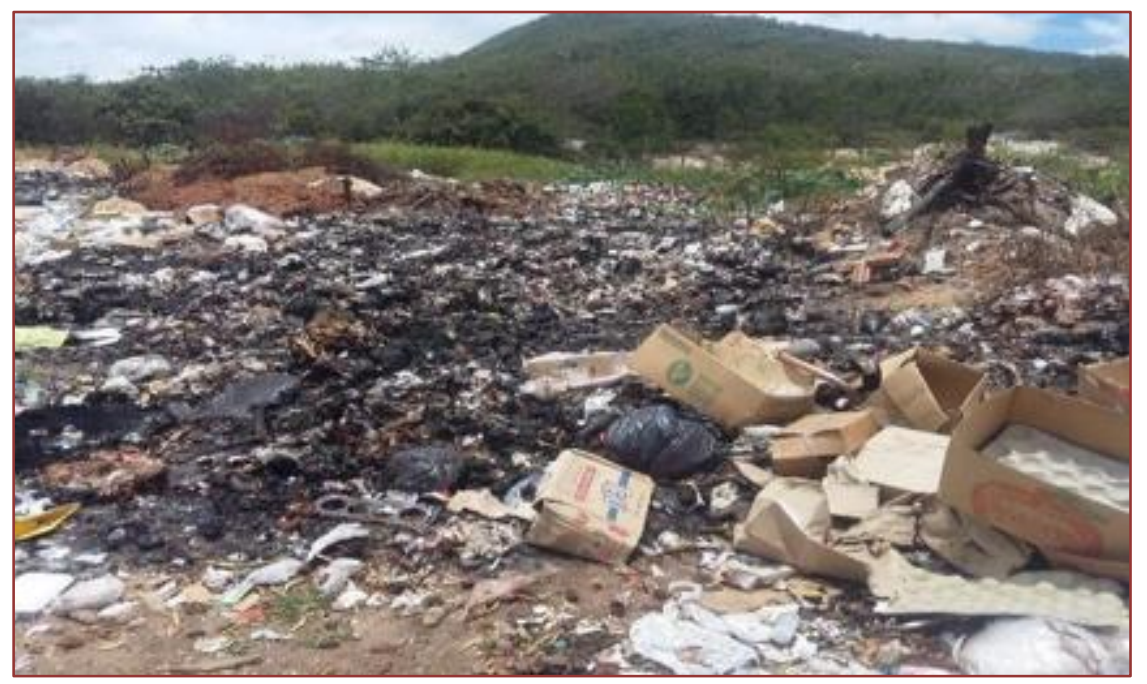

\section{CONCLUSÕES}

A disposição final dos resíduos sólidos urbanos no município de Jacaraci -BA é realizada inadequadamente, gerando diversos transtornos ambientais, sanitários, sociais e econômicos. Por meio da educação ambiental podem ser encontradas soluções para esses problemas.

Sugere-se que sejam realizados novos trabalhos nos lixões das cidades brasileiras, para que se obtenham dados a serem utilizados na conscientização e sensibilização dos moradores sobre os conceitos de educação ambiental, de forma a se reduzir, reutilizar e reciclar os materiais que estão sendo jogados diretamente no lixo.

Além disso, é preciso alertar os gestores municipais sobre as leis e legislações vigentes, mostrando as práticas ambientais corretas e minimizando, assim, os impactos ambientais.

\section{REFERÊNCIAS}

[1] Brasil, Ministério do Meio Ambiente, Conama - Conselho Nacional do Meio Ambiente. Resolução Conama no 316 de 29 de outubro de 2002. Dispõe sobre procedimentos e critérios para o funcionamento de sistemas de tratamento térmico de resíduos, Brasília, 2002.

[2] Brasil, Ministério do Meio Ambiente, Conama - Conselho Nacional do Meio Ambiente. Resolução CONAMA no 358 de 29 de Abril de 2005 tratam dos resíduos sólidos oriundos dos serviços de saúde, Brasília, 2005.

[3] França, R. G.; Ruaro, E. C. R. Diagnóstico da disposição final dos resíduos sólidos urbanos na região da 
Associação dos Municípios do Alto Irani (AMAI), Santa Catarina. Ciência \& Saúde Coletiva, v. 14, n. 6, Rio de Janeiro, 2009.

[4] Ibge, Instituto Brasileiro de Geografia e Estatística, Censo 2010. Primeiros Dados do Censo em 2010.

[5] Lima, Luis Mário Queiroz. Lixo - Tratamento e Biorremediação. Hemus Editora Ltda. São Paulo. 2001.

[6] Nóbrega, M. F.; Carvalho, P. R. S. O Projeto de Coleta Seletiva no Parque Nacional da Tijuca. Engenharia de Produção. In: Encontro Curitiba - PR, 22, 2002.

[7] Pereira, S. S; Melo, J. A. B. Gestão dos resíduos sólidos urbanos em Campina Grande/PB e seus reflexos socioeconômicos. Revista Brasileira de Gestão e Desenvolvimento Regional. v. 4, n. 4, p. 193-217, Taubaté, SP, 2008.

[8] Resende, I. L. M.; Vieira, J. E. Coleta Seletiva: Subsídio para a Associação dos Catadores de Materiais Recicláveis - Quirinópolis - GO. In: Seminário Nacional De Resíduos Sólidos - Projetos Sócio-econômicos, 7., São Paulo, 2004.

[9] Schneider, F. V. Manual de gerenciamento de resíduos sólidos de serviços de saúde. Caxias do Sul: Educs, 2004. 319 p. Acesso em: 07 abr. 2016. 


\section{Capítulo 2}

Análise da gestão e gerenciamento dos Resíduos de Serviços de Saúde (RSS) e seus impactos ambientais: Uma revisão bibliográfica

\section{Graciete da Silva Figueiredo}

Ricardo Jorge Amorim de Deus

Simonny do Carmo Simões R. de Deus

Roberto Carlos Figueiredo

Resumo: Nos ambientes de saúde a ausências de informações acerca dos RSS pode inviabilizar a gestão e o gerenciamento dos serviços de saúde em realizar a avaliação, controle e manejo desses materiais. Nesse sentido, objetiva-se realizar um estudo de revisão bibliográfica para analisar o gerenciamento dos RSS a partir das legislações pertinentes para reduzir os riscos e os impactos ocupacionais, aos usuários e ao meio ambiente. Realizou-se uma abordagem qualitativa e análise exploratória das informações, em seis artigos no período entre 2014 e 2018, nas bases de dados: Scientific Electronic Library Online (SCIELO), Literatura Latino-Americana e do Caribe em Ciências da Saúde (LILACS), Medical Literature Analysis and Retrieval System OnLine (MEDLINE), com descritores: gerenciamento dos serviços de saúde; resíduos dos serviços de saúde; resíduos hospitalares; e saúde e meio ambiente. Observou-se um pequeno crescimento no número de publicações. Conclui-se, que o gerenciamento e o manejo dos RSS nas Instituições de saúde públicas ou privadas, apresentam algumas deficiências, o que potencializa os riscos à saúde pública e à natureza, sendo necessário, além do cumprimento das determinações legais, o investimento na educação ambiental (EA) com relação ao manejo adequado dos RSS, na construção e implantação de políticas para uma gestão adequada e oferecer a educação permanente para gestores e colaboradores internos e externos, por meio de palestras, oficinas e outros.

Palavras-chave: RSS; Manejo; Legislação Ambiental; Educação Ambiental.

1.INTRODUÇ̃̃O 
Os RSS são gerados na assistência médica humana ou animal, provenientes de hospitais, clínicas, laboratórios, drogarias e farmácias, centro de zoonoses, estabelecimentos de ensino e pesquisa na área da saúde, entre outros. São resíduos biológicos, químicos, radioativos, comuns, perfuro cortantes e escarificantes (BRASIL, 2004).

Em 1993, a Associação Brasileira de Normas Técnicas (ABNT) através da Norma Brasileira de Referência (NBR) no 12.808 classificou os RSS. Em seguida o CONAMA na Resolução no 005/1993, propõe nova classificação e o gerenciamento dos RSS, inclusive instituindo a obrigatoriedade de elaboração do Plano de Gerenciamento de Resíduos Sólidos - PGRSS (BRASIL, 1993). Posteriormente, a Agência Nacional de Vigilância Sanitária (ANVISA) e o CONAMA compatibilizaram suas normativas e a Resolução da Diretoria Colegiada (RDC) da ANVISA n ${ }^{\circ}$ 306, de 07 de dezembro de 2004, classifica os RSS e define procedimentos para o manejo dos diferentes grupos (A, B, C, D e E, e subdivide o grupo A em 05 tipos: A1 a A5) e a Resolução do CONAMA n ${ }^{\circ}$ 358, de 29 de abril de 2005 (BRASIL, 2005), dispõe sobre o tratamento e disposição final de tais resíduos. São políticas públicas que visam a proteção da saúde ocupacional, pública e do meio ambiente, ratificadas pela Lei $\mathrm{n}^{\circ}$ 12.305, de 02 de agosto de 2010, que instituiu a Política Nacional de Resíduos Sólidos. Atualmente a RDC no 222 de 29 de março de 2018 da ANVISA define os requisitos de boas práticas de gerenciamento do RSS e entrará em vigor no mês de setembro do ano em curso para revogar a RDC 306/04.

Apesar dos marcos legais norteadores para a gestão dos RSS, esta ainda é um desafio às administrações na saúde, pois é preciso investimentos em estruturas e capacitação, para a redução e tratamento somente da fração necessária (BRASIL, 2006) e a criação de estratégias que garantam o manejo seguro (BRASIL, 2004). Por esse motivo, esta pesquisa busca realizar um estudo de revisão bibliográfica no qual o objetivo é analisar a gestão e o gerenciamento dos RSS nas Instituições de saúde a partir das legislações supracitadas para reduzir os riscos ocupacionais, aos usuários e ao meio ambiente.

\section{METODOLOGIA}

0 presente estudo consta de uma revisão de literatura, com abordagem qualitativa, que abrange a temática gestão e gerenciamento dos RSS. Para Guerra (2014), esse tipo de pesquisa aprofunda os fenômenos estudados, sem a preocupação com números. Trata-se de uma pesquisa bibliográfica que utiliza material já publicado, livros, artigos e internet (SILVA, 2009).

\subsection{AMOSTRAGEM DE DADOS}

A busca dos dados foi realizada no período de janeiro a julho de 2018, na base de dados Scientific Electronic Library Online (SCIELO), Literatura Latino-Americana e do Caribe em Ciências da Saúde (LILACS), Medical Literature Analysis and Retrieval System On-Line (MEDLINE), com os descritores: gerenciamento dos serviços de saúde; resíduos dos serviços de saúde; resíduos hospitalares; e saúde e meio ambiente.

\subsection{TRATAMENTO DE DADOS}

Para a amostragem do estudo utilizou-se os critérios de inclusão como os artigos que abordassem as questões: Gerenciamento dos serviços de saúde; Resíduos dos serviços de saúde; Resíduos hospitalares; Relação saúde e meio ambiente, escritos em língua portuguesa, publicados entre 2014 a 2018 e que estivessem disponíveis integralmente nas bases de dados. E como exclusão os artigos não ou parcialmente relacionados ao tema. Desse modo, a questão norteadora foi: na literatura científica nacional, como ocorre a gestão e o gerenciamento dos RSS, visando à proteção dos trabalhadores, a preservação da saúde pública e do meio ambiente. Sendo que a análise das informações foi realizada por meio de leitura exploratória, seletiva e analítica do material encontrado. 


\section{RESULTADOS E DISCUSSÃO}

Os dados foram analisados a partir de duas unidades temáticas:

\subsection{CARACTERIZAÇÃO DO GERENCIAMENTO DOS RESÍDUOS DE SERVIÇOS DE SAÚDE (GRSS) NO BRASIL}

O gerenciamento de resíduos de serviços de saúde (RSS) é um conjunto de procedimentos técnicos e legais para a gestão de resíduos em qualquer tipo de estabelecimentos de saúde (BRASIL, 2004). Porém essa prática tem ocorrido de maneira inadequada devido falta de infraestrutura, com a ausência de uma estrutura pública e/ou privada responsável pelos resíduos, desde a geração até a sua destinação final, falta de informações, entre outros, (RIZZON et al. 2015, COSTA\& BATISTA, 2016).

Estudos realizados na Região Metropolitana de Belo Horizonte, no estado do Espirito Santo e na região de Fernandópolis no estado de São Paulo evidenciaram diversas falhas no processo de manejo, sendo necessário o treinamento de gestores (OLIVEIRA et al., 2018). Contudo, um achado nas produções científicas mostra um modelo de gestão e gerenciamento adequado no estado de Minas Gerais (SZCZERBOWSKI \& MORAIS, 2017).

Para se obter o conhecimento sobre o manejo dos RSS é essencial o processo de educação permanente, (VITAL; GUIMARÃES, 2018). E que seja estendido a todas as categorias profissionais por meio de palestras visando a responsabilidade ética (RIZZON et al., 2015). Nessa ótica, o processo educativo dos profissionais deve ser encarado como uma prática contínua para motivar os participantes à uma gestão proativa.

\subsection{O MANEJO E A CLASSIFICAÇÃO DOS RSS, RELACIONADOS ÀS NORMAS AMBIENTAIS VIGENTES}

0 manejo de RSS é definido como todas as ações realizadas para gerenciar os resíduos dentro e fora dos estabelecimentos de saúde, tais como: identificação, segregação, acondicionamento, tratamento intermediário, transporte interno, armazenamento temporário, armazenamento externo, tratamento final e disposição final (OLIVEIRA et al., 2018).

No Brasil as Resoluções no 306/ 2004 da ANVISA, e a no 358/2005 do CONAMA transferiram a responsabilidade do manejo e da elaboração do PGRSS para os geradores, mas o manejo ainda não está sendo operacionalizado de forma adequada (COSTA, 2016).

A RDC ANVISA nº306/04 e a Resolução CONAMA no 358/05 classificam os resíduos conforme grupos de risco. Grupo A - Resíduos Biológicos ou Infectantes; Grupo B - Resíduos Químicos ; Grupo C - Resíduos Radiativos; Grupo D - Resíduos Comuns; Grupo E - Resíduos perfurocortantes. Tais grupos exigem formas de gerenciamento específicas em todas as etapas de manejo. Recentemente foi editada a Resolução no 222 de 29/03/2018 da ANVISA, dispondo sobre os critérios das boas práticas de gerenciamento dos RSS para revogar a RDC no 306/2004.

A Associação Brasileira de Normas Técnicas (ABNT) também publicou algumas normas em relação ao controle dos RSS, que podem ser observadas no quadro 1, abaixo:

Quadro 1 - Normas relativas aos RSS (ABNT, 1993a; 1993b; 1993c; 1993d; 1994;1997; 2000; 2001;2004; 2008 )

\begin{tabular}{|c|c|}
\multicolumn{2}{|c|}{ NORMAS } \\
\hline NBR12.808/1993a & Classificação de Resíduos de Serviços de Saúde - RSS, \\
\hline NBR12.810/1993b & Procedimento de Coleta de Resíduos de Serviços de Saúde \\
\hline NBR12.809/1993c & Procedimento de Manuseio dos Resíduos de Serviços de Saúde \\
\hline NBR12.807/1993d & Terminologia dos Resíduos de Serviços de Saúde. \\
\hline NBR 9.190/1994 & Classificação de sacos plásticos para acondicionamento de lixo. \\
\hline NBR13.853/1997 & Caracterização dos coletores perfurocortantes \\
\hline NBR7.500/2000 & Símbolos de Risco e Manuseio para transporte e Armazenagem de Materiais \\
\hline NBR14.652/2001 & Especificação dos requisitos para construção e inspeção de coletores do grupo A \\
\hline NBR10.004//2004 & Classifica os RS quanto aos riscos potenciais ao meio ambiente e à saúde pública. \\
\hline NBR9.191/2008 & Especificação de sacos plásticos para acondicionamento de lixo. \\
\hline
\end{tabular}


De acordo com a RDC n. 306/04 as instituições de saúde devem realizar a capacitação e o treinamento inicial e contínuo às pessoas envolvidas no gerenciamento de resíduos (OLIVEIRA et al., 2018). Portanto, a EA precisa ser um processo permanente na área da saúde.

\section{CONCLUSÕES}

Por meio da literatura pesquisada, conclui-se que o gerenciamento e manejo dos RSS nas instituições de saúde, quer sejam empresas públicas ou privadas, apresentam algumas deficiências, o que aumenta consideravelmente o potencial de risco desses resíduos à saúde pública e à natureza. Para sanar essa situação, não se pode restringir isso apenas ao cumprimento das determinações legais, mas sim ao investimento na EA com relação ao manejo adequado dos RSS, na construção e implantação de políticas para uma gestão adequada e responsabilidade ética, o que leva ao processo de sensibilização dos envolvidos, mitigação dos impactos ambientais e da otimização de custos na área da saúde. Além disso, os resultados demonstram a necessidade de oferecer a educação permanente para gestores e colaboradores internos e externos dos estabelecimentos de saúde, quer seja por meio de palestras, oficinas e outros, para que se promovam mudanças comportamentais sustentáveis nas relações de consumo e de geração RSS.

\section{REFERÊNCIAS}

[1] Brasil, MS, Agencia Nacional de Vigilância Sanitária. RDC no 306/04, de 07 dez 2004. Dispõe sobre o regulamento técnico para o gerenciamento de resíduos de serviços de saúde. Diário Oficial da União 22 dez. 2004.

[2] _ _ Resolução Conama no 5, de 5 de agosto de 1993.

[3] Publicada no DOU no166, de 31 de agosto de 1993, Seção 1, páginas 12996-129981993.

[4] _. MS, Agencia Nacional de Vigilância Sanitária. RDC no 222 de 29 de março de 2018. Diário oficial da União, nํㅡ. 61 .

[5] _ Nacional de Vigilância Sanitária. Gerenciamento dos resíduos de saúde. Tecnologia em serviço de saúde. Editora Anvisa, 1aㅡ edição, Brasília, 2006.

[6] _ C_ Conama.. Resolução no 358/05, de 29 de abril de 2005. Acesso em: 01/07/2018.

[7] Disponível em : http://www.mma.gov.br/port/conama/legiabre.cfm?codlegi=462.

[8] Costa, V. m; Batista, N. J. C. Gerenciamento dos resíduos de serviços de saúde: Uma revisão integrativa. Rev. Saúde em Foco. Teresina, v. 3, n. 1, art. 1, p. 124-145, jan./jun. 2016.

[9] Costa, M. A. B. et al. Resíduos dos serviços de saúde: coleta e tratamento. Singeurb, 25 a 27 de outubro de 2017.

[10] Guerra, E. L. A. Manual de pesquisa qualitativa. EAD. Anima Educação. Centro universitário Una, 2014.

[11] Oliveira, L. P. et al. Fatores associados ao manejo adequado de resíduos de serviços de saúde entre profissionais de enfermagem. Rev baiana enferm, 2018.

[12] Szczerbowski, A. C. Morais, C. R. Manejo de resíduos sólidos em unidade básica de saúde da cidade de estrela do Sul, Minas Gerais, Brasil. Getec, v.6, n.11, p.29-40/2017.

[13] Vital, M. S. B.; Guimarães, P. S. S. Plano de gerenciamento de resíduos de serviços de saúde: descortinando conhecimento dos enfermeiros. Gep News, Maceió, v.1, n.1, p. 167-171, jan./mar. 2018.

[14] Silva, Renata. Metodologia do trabalho Científico. Uniasselvi, Leonardo Da Vinci. - Indaial: Asselvi, p. 50, 2009.

[15] Rizzon, F. et al. Desafio no gerenciamento de resíduos em serviços públicos de saúde. Revista de Gestão em Sistemas de Saúde - RGSS. Vol. 4, N. 1. Janeiro/Junho. 2015. 


\section{Capítulo 3}

\section{Programa de gestão de resíduos - Poli USP Recicla}

\section{Welson Gonçalves Barbosa Junior \\ Pedro Paulo Consul Kassardjian \\ José Carlos Mierzwa}

Resumo - O Programa de Gestão de Resíduos da Escola Politécnica da USP, denominado Poli USP Recicla, foi criado em 2006 com o objetivo de transformar a gestão sustentável de todos os resíduos gerados nas diversas atividades da Poli em uma extensão natural de suas atividades. 0 programa é delineado em consonância com as diretrizes da Escola e busca cumprir na íntegra a legislação vigente, além de trabalhar com o conceito de resíduo mínimo,evitando a confecção de impressos descartáveis e fazendo uso intenso da mídia eletrônica e de placas permanentes. 0 Poli Recicla administra cinco projetos principais: Gestão de Lâmpadas Fluorescentes; Gestão de Pilhas e Baterias; Gestão de Resíduos Laboratoriais; Gestão de Toners/Cartuchos; Coleta Seletiva de Resíduos Não Perigosos. A equipe do Poli Recicla continua com o processo de consolidação e ampliação destes projetos, com envolvimento dos funcionários, docentes e alunos da Escola, além dos funcionários terceirizados da limpeza. 0 programa teve reconhecimento institucional e foi solicitado a auxiliar na implantação dos processos em instituições externas, convidado para apresentações em eventos de gestão ambiental, além de auxiliar outras unidades da USP.

Palavras-chave: Gestão Sustentável. Resíduos. Reciclagem. Destinação final. 


\section{INTRODUÇÃO}

O Programa Poli Recicla integra a Escola Politécnica (Poli) à Superintendência de Gestão Ambiental da USP, que se dedica a promover a gestão sustentável dos resíduos dentro da USP. 0 Programa é gerenciado por um grupo da comunidade politécnica, que inclui alunos, funcionários e professores, mas está aberto à participação da comunidade.

Dado o tamanho da Escola Politécnica, que ocupa um total de nove prédios por onde passam mais de 17000 pessoas por dia, e a complexidade dos resíduos gerados, que incluem desde resíduos típicos de escritório até resíduos perigosos de diferentes laboratórios, fez-se necessária a criação de um programa de gestão de resíduos.

Todos os projetos são amplamente divulgados à comunidade politécnica através de ferramentas de divulgação interna, tais como e-mail (Informativo da Poli), intranet, sites da Poli e do Poli Recicla, jornais do grêmio e dos centros acadêmicos, jornais da USP etc. O processo de implantação de todos os projetos envolveu análise criteriosa de produtos e serviços, assim como treinamento a todos os envolvidos.

O Poli USP Recicla tem como objetivo principal gerir de forma sustentável os resíduos produzidos nas diversas atividades da Escola Politécnica. Neste sentido, a equipe busca trabalhar sempre em colaboração com a comunidade Poli, responsável pela geração e gestão dos resíduos, buscando de forma participativa soluções simples e eficazes dentro da estrutura existente. 0 programa é delineado em consonância com as diretrizes da Escola, buscando cumprir na íntegra a legislação vigente e desenvolver novas soluções mais avançadas.

Para cada projeto gerenciado pelo Poli Recicla existem objetivos específicos:

- Gestão de Lâmpadas Fluorescentes e Mistas: Eliminar por completo o descarte de lâmpadas fluorescentes e mistas em locais inadequados.

- Gestão de Pilhas e Baterias: Destinar corretamente os resíduos de pilhas e baterias gerados pela comunidade politécnica.

- Gestão de Resíduos Laboratoriais: Consolidar um levantamento de todos os resíduos laboratoriais da Escola, identificando os tipos, a quantidade, o estado físico, o estado das embalagens, a periodicidade da geração e sua localização.

- Gestão de Toners/Cartuchos: Garantir que os cartuchos/toners recolhidos na POLI sejam transportados, manuseados e tratados por empresas especializadas.

Coleta Seletiva de Resíduos Não Perigosos: Reduzir continuamente o índice de mistura entre resíduos recicláveis e não recicláveis, garantir a correta destinação do resíduo reciclável para uma cooperativa e treinar os funcionários envolvidos

\section{MATERIAL E MÉTODOS}

Cada projeto do Poli Recicla apresenta uma metodologia com suas particularidades, porém todos apresentam uma mesma estrutura de base. 0 processo de gestão é sempre elaborado pela identificação dos pontos de coleta, treinamentos, aquisição de coletores e contratação de serviço de coleta, descontaminação e destino final dos resíduos por empresa especializada. Os alunos monitores têm a responsabilidade de fiscalizar as condições dos coletores, as quantidades de resíduos acumulados e a disposição destes nos coletores até sua destinação final.

\section{RESULTADOS E DISCUSSÃO}

\subsection{GESTÃO DOS RESÍDUOS PERIGOSOS}

\subsubsection{LÂMPADAS FLUORESCENTES}

Classificadas como resíduo perigoso pela NBR 10.004/2004, as lâmpadas fluorescentes necessitam de tratamento específico. De dezembro de 2010 a dezembro de 2015, foramenviadas para descontaminação 37.901 unidades sendo que 12.789 (41,6\%) não saíram do almoxarifado, sendo provenientes de outras fontes.

O Poli Recicla utiliza três indicadores para medir esse processo: 
(a) A massa de mercúrio que foi recuperada, considerando, segundo a Apliquim Brasil Recicle, que cada lâmpada fluorescente tubular possua, em média, $8 \mathrm{mg}$ de mercúrio metálico.

(b) População com sua água de abastecimento prejudicada, durante uma semana, caso o mercúrio recuperado no indicador (a) fosse lançado diretamente no sistema. Neste caso considerou-se o consumo per capita de 250 litros diários e o padrão de potabilidade para o mercúrio da Portaria MS №518/2004.

(c) Valor gasto com a descontaminação, considerando um custo médio de $\mathrm{R} \$ 0,50$ por lâmpada.

Assim, os valores levantados, até dezembro de 2015 foram:

(a) Recuperação de 301 gramas de mercúrio metálico;

(b) População de 172.165 habitantes;

(c) $\mathrm{R} \$ 20,770,00$ gastos para atingir este grande benefício ao meio ambiente.

\subsubsection{PILHAS E BATERIAS}

Este resíduo também é classificado como perigoso pela ABNT NBR 10.004/2004, ou seja, também necessita de tratamento específico por liberarem ácidos e metais pesados. Durante o ano de 2015 foram coletados $420 \mathrm{~kg}$ de pilhas e baterias. Ao longo de seis anos de projeto, já foram coletadas mais de 4,8 toneladas. Em Outubro de 2012, o Poli Recicla fez uma parceria com o CEDIR/CCE, e desde então o descarte de pilhas tem sido feito por eles, eliminando os custos do processo da Poli-USP.

\subsubsection{RESÍDUOS LABORATORIAIS}

Este resíduo apresenta características que os colocaram na Classe I da NBR 10.004. São elas: inflamabilidade, corrosividade, reatividade, toxicidade e/ou patogenicidade. Em 2015 mantiveram-se os processos de gestão da coleta de resíduos laboratoriais, onde foram programados o descarte correto de 7.5 toneladas de resíduos perigosos que aguardam licitação para serem descartados.

\subsection{GESTÃO DOS RESÍDUOS NÃO PERIGOSOS}

\subsubsection{COLETA SELETIVA NOS PRÉDIOS DA POLI}

A Gestão de Resíduos não perigosos (Classe II pela ABNT NBR 10.004/2004) teve início em 2008. Atualmente, todos os prédios da Escola contam com coletores internos, externos e quadros informativos. Em 2015 foram coletadas mais de 45 toneladas de resíduos de Classe II. Para medição dos resultados desse processo, foi criada a "Semana dos Indicadores" com periodicidade semestral. Portanto, duas vezes ao ano, a equipe do Poli Recicla, durante uma semana retira amostras de diversos coletores para pesar a quantidade de lixo comum entre os recicláveis e a quantidade de resíduo reciclável no meio do lixo comum. Em 2014, encontramos 4,7\% de não recicláveis entre os recicláveis e 8,7\% de recicláveis no lixo comum. Esses números indicam bons resultados, porém constitui um alerta sobre a necessidade de campanhas continuadas junto aos usuários.

\subsubsection{CICLÉIAS - COLETA SELETIVA ABERTA À COMUNIDADE}

Em 2008 o Poli Recicla aderiu à ação do Programa USP Recicla de instalação de pontos de coleta seletiva, dentro do convênio com a Limpurb. Foram instaladas quatro "Cicléias". Deste então, vem sendo registrada a coleta semanal de 10 mil litros de material para triagem e destinação correta.

\subsection{OUTROS RESÍDUOS}

\subsubsection{GESTÃO DE TONERS E CARTUCHOS USADOS OU VENCIDOS}

Toners e cartuchos de impressão usados ou vencidos devem ser descartados de maneira adequada, pois podem contaminar o meio ambiente. 0 material utilizado nos departamentos da Escola Politécnica é encaminhado ao Poli Recicla, que faz a devolução aos fabricantes, caracterizando um processo pioneiro de Logística Reversa. Esta logística é realizada desde 2009, tendo sido devolvidas, desde o início do 
programa, aproximadamente, 3.88100 unidades.

\subsubsection{GESTÃO DE RESÍDUOS DE CONSTRUÇÃO CIVIL}

Em 2012, foi sugerido pelo Poli Recicla e acatado pelos gestores de contrato do Serviço de Manutenção e Obras da Poli a inclusão de um adendo nos contratos com os prestadores de serviços de obras no sentido de contemplar nesses contratos a gestão de resíduos de construção civil para atender os critérios exigidos nas legislações vigentes. Desde então, continuamos na tentativa de conscientização de todas as prestadoras da obrigatoriedade desse serviço e na capacitação dos funcionários para lidar com possíveis adversidades. Visando tal capacitação e a difusão do nosso protocolo de gestão de resíduos de obra, criamos uma cartilha de Gestão de Resíduos de Obras para melhor instruir a todos que precisem realizar tal operação.

\subsection{DOAÇõES DE CANECAS DURÁVEIS}

Em 2012, o Poli Recicla continuou a distribuir canecas duráveis para serem utilizadas nos restaurantes universitários a fim de reduzir a utilização de copos descartáveis. No ato da retirada da caneca, o interessado recebe breves informações sobre o programa do Poli Recicla e assina uma folha de controle.

\subsection{TREINAMENTOS, PALESTRAS E REUNIÕES}

Em 2015 foi realizado o XI Treinamento "Gestão de Resíduos Não Perigosos" para equipe de limpeza, com grande adesão de participantes e com significativa melhoria nas práticas da gestão de resíduos por todos os envolvidos. A intenção do treinamento é atualizar os funcionários de novos procedimentos e dá-los informação suficiente de modo a gerar autonomia nas suas decisões de trabalho, deixando de depender de instrução e supervisão periódica de instâncias superiores. Nesta edição compareceram 96 funcionários, caracterizando uma adesão de $94 \%$, como pode ser visto na tabela a seguir

No final de ano, a equipe do Poli Recicla reuniu zeladores, administradores e gestores dos prédios, além de secretários(as), assistentes e diretores(as) para apresentar os novos processos, os indicadores dos processos já conhecidos, recolher sugestões, críticas, ideias e traçar objetivos e metas para o ano seguinte. Com este trabalho buscamos integrar o nosso trabalho com o cotidiano da Escola Politécnica.

\subsection{DIVULGAÇÃo}

Em 2012, finalizou-se a migração do site do Poli Recicla para o novo domínio do servidor do site da Escola Politécnica. Assim, a equipe do Poli Recicla foi capacitada para realizar de forma autônoma suas publicações, auxiliando a cumprir a meta de não realizar divulgações impressas. Além disso, será nesta nova plataforma que o Sistema de Gestão de Resíduos Laboratoriais será desenvolvido a partir do modelo já existente.

\subsection{ATENDIMENTO AO PÚBLICO}

O Poli Recicla continua a realizar de modo satisfatório e com crescente demanda, os atendimentos às solicitações externas, realizadas pelos mais diversos públicos sobre diferentes assuntos. Além de ser procurado pelo público externo, ocorreram diversas solicitações internas para disseminar suas boas práticas na gestão de resíduos.

\subsection{PROGRAMA DE EDUCAÇÃO AMBIENTAL}

No segundo semestre de 2012, a equipe do Poli Recicla desenvolveu um plano de trabalho para realizar um programa de educação ambiental em instituições públicas de ensino em comunidades carentes. 0 projeto aconteceu durante todo o ano de 2013 na E.E Prof. Renato de Arruda Penteado onde foram disseminadas boas práticas de gestão de resíduos em classes menos favorecidas da sociedade e capacitamos jovens a serem multiplicadores do conhecimento em suas comunidades. 


\section{CONCLUSÕES}

Após pouco mais de nove anos de atividades, o Poli Recicla avançou na sua consolidação e tornou-se referência de gestão de resíduos para diversas universidades brasileiras, sendo constantemente requisitado para auxiliar na implantação de gestões de resíduos em outras entidades.

A estratégia de centrar esforços na criação de infraestrutura para a gestão, associada a treinamento dos profissionais afetados pela nova forma de trabalho, revelou-se eficaz, como demonstram os resultados do programa de coleta. Mas o Poli Recicla não pretende parar por aí. Para garantir que haja uma melhoria contínua, é necessário que sempre ocorram outros treinamentos para manter todos os envolvidos atualizados.

O gerenciamento de resíduos sólidos, mais que uma responsabilidade legal, é uma necessidade social e ambiental premente. A Escola Politécnica como educadora e formadora de opinião deve capacitar seus alunos, futuros profissionais no mercado de trabalho, a desenvolverem suas atividades de forma mais limpa e ambientalmente sustentável. A Escola deve, antes de tudo, servir de exemplo.

\section{AGRADECIMENTOS}

Agradecemos aos funcionários, professores, diretoria da Escola Politécnica e a toda equipe do Poli USP Recicla que apoia e se dedica ao projeto diariamente.

\section{REFERÊNCIAS}

[1] Abnt. NBR 10.004/2004. Classificação de resíduos sólidos. Elaborada em 1987, revisada em 2004.

[2] Portaria MS №518/2004. Procedimentos e responsabilidades relativos ao controle e vigilância da qualidade da água para consumo humano e seu padrão de potabilidade. 


\section{Capítulo 4}

Descarte de óleo de cozinha no Ponto de Entrega Voluntário (PEV) da Lagoa do Japiim - Diagnóstico de Educação Ambiental

\section{Nelcinda Cleto Fernandes \\ Itaní Sampaio de Oliveira}

\section{Cláudio Nahum Alves}

Resumo: A degradação do meio ambiente provocada pelo descarte incorreto de resíduos tem alertado sobre a necessidade de reciclagem desses resíduos utilizando, assim, a logística reversa. Dessa forma, objetiva-se realizar o diagnóstico de funcionamento do Ponto de Entrega Voluntário - PEV localizado na Lagoa do Japiim, conforme o descarte de óleo de cozinha realizado pela população, principalmente, pelos moradores da Zona Sul da cidade de Manaus. Para isso foi utilizado o estudo de caso com aplicação da técnica 5W2H e, como metodologia auxiliar, a elaboração de folder para a divulgação do serviço público. Os resultados mostram que deve haver a implantação de um programa de gestão continuada, a fim de atuar de forma preventiva e corretiva, para promover o funcionamento ininterrupto do sistema surgindo, assim, a necessidade de ampla divulgação dos serviços disponíveis e programas de educação ambiental constantes na comunidade.

Palavras Chave: Reciclagem. Resíduos. Meio ambiente.

ARTIGO PUBLICADO NO 15 CONGRESSO NACIONAL DE MEIO AMBIENTE, EM POÇOS DE CALDAS/MG 


\section{INTRODUÇÃO}

O descarte de óleo de cozinha usado tem sido um tema em discussão pelas comunidades técnica e científica, com a intenção de desenvolver alternativas de reaproveitamento desse resíduo, que promova a preservação do meio ambiente, a economia local, o bem-estar social, o conforto e a qualidade de vida.

Assim, torna-se necessária a utilização da logística reversa, pois, permite a redução de custos para a indústria, devido à aquisição desses insumos, tendo em vista que os resíduos retornam para a cadeia produtiva, como, por exemplo, o que ocorre com o óleo de cozinha, que é utilizado nos alimentos e, quando descartados adequadamente podem ser destinados à produção de sabão em barra e detergentes.

Por isso, considerando que o Ponto de Entrega Voluntária da Lagoa do Japiim é o único, dos quatro existentes na cidade de Manaus, a coletar óleo de cozinha, para atender uma demanda de aproximadamente dois milhões de habitantes objetiva-se avaliar como está ocorrendo o descarte desse resíduo, comumente utilizado no dia-a-dia das pessoas e altamente poluidor, a fim de diagnosticar o funcionamento do PEV e a educação ambiental dos usuários.

\section{METODOLOGIA}

Para diagnóstico do funcionamento do PEV da Lagoa do Japiim utilizou-se do estudo de caso, em uma abordagem descritiva, segundo Gil (2009) e, como metodologia auxiliar foi utilizada a pesquisa-ação, como forma de resolver os problemas vivenciados com maior eficiência e com base em uma ação transformadora (THIOLLENT, 2011) utilizando-se, assim, a técnica 5W2H para mapear processos e encontrar soluções para os problemas identificados. Além disso, foi realizada a confecção de folders, de acordo com Paula e Carvalho (2014), para, além da divulgação do PEV atuar, também, como instrumento educacional, a fim de elucidar questões envolvendo o descarte do óleo de cozinha.

\section{RESULTADOS E DISCUSSÃO}

Como resultado dessa pesquisa foi confeccionado um modelo de folder (Figuras 1 e 2) disponibilizado para a divulgação do PEV e a ser distribuído nas ações sobre educação ambiental.

Figura 1: Parte frontal do folder.

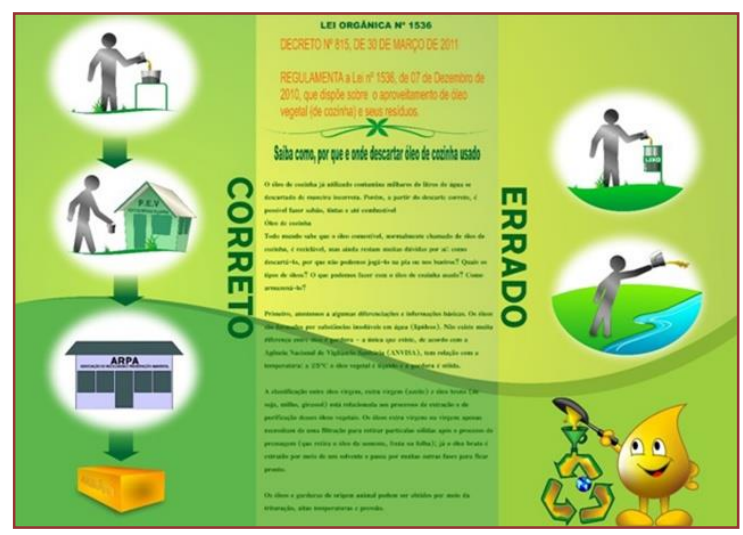

Fonte: Autores (2018).
Figura 2: Verso do folder.

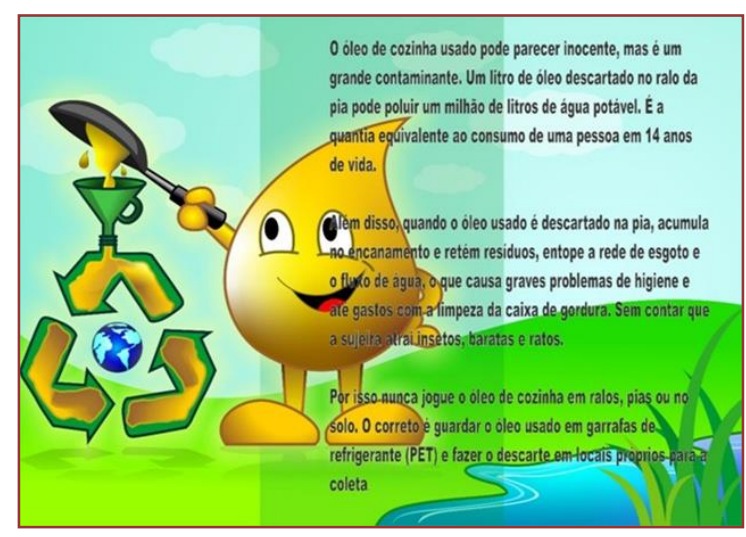

Fonte: Autores (2018).

Na parte frontal do folder foram abordadas as legislações pertinentes citando a Lei Orgânica ${ }^{\circ} 1.536$ de 07/12/2010 e o Decreto ${ }^{\circ} 815$ de 30/03/2011, ambos sobre o aproveitamento de óleo vegetal e seus resíduos, bem como a elucidação sobre as formas de descarte de resíduos. No verso do folder estão relatadas as consequências do descarte incorreto do óleo de cozinha, os impactos que ocasiona na natureza e a forma adequada de armazená-lo, sempre utilizando como animação uma gota de óleo em forma de personagem, com intuito de atingir, principalmente, as crianças.

Os resultados obtidos com a aplicação da técnica de gestão 5W2H mostram que, através de planejamento, manutenção e divulgação do PEV é possível aperfeiçoar o funcionamento do mesmo, por um custo 
acessível para o órgão gestor (Prefeitura Municipal de Manaus - PMM), no valor de R \$1.000,00 mensais (Tabela 1), visto não haver manutenção constante do ponto sendo sugerida a realização das seguintes etapas: Inspeção mensal; Manutenção preventiva; Implantação de coletores; e Realização de ações ambientais.

Tabela 1: Implantação do 5W2H no PEV

\begin{tabular}{|c|c|c|c|c|c|c|}
\hline WHAT? & WHO? & WHERE? & WHEN? & WHY? & HOW? & $\begin{array}{l}\text { HOW } \\
\text { MUCH? }\end{array}$ \\
\hline O QUE? & QUEM? & ONDE? & QUANDO? & PORQUE? & COMO? & $\begin{array}{l}\text { QUANTO } \\
\text { CUSTA? }\end{array}$ \\
\hline Inspeção & PMM & PEV & $\begin{array}{c}\text { Uma vez por } \\
\text { mês }\end{array}$ & $\begin{array}{l}\text { Prestação de } \\
\text { contas }\end{array}$ & $\begin{array}{l}\text { Gestão do } \\
\text { PEV }\end{array}$ & - \\
\hline Manutenção & PMM & PEV & $\begin{array}{c}\text { Duas vezes } \\
\text { por mês }\end{array}$ & $\begin{array}{l}\text { Higiene do } \\
\text { local }\end{array}$ & $\begin{array}{c}\text { Limpeza e } \\
\text { material }\end{array}$ & $\mathrm{R} \$ 600,00$ \\
\hline $\begin{array}{l}\text { Implantação } \\
\text { de coletores }\end{array}$ & PMM & $\begin{array}{l}\text { Outros } \\
\text { pontos } \\
\text { dcidade }\end{array}$ & $\begin{array}{l}\text { Sempre que } \\
\text { necessário }\end{array}$ & Acessibilidade & $\begin{array}{l}\text { Em pontos } \\
\text { estratégicos }\end{array}$ & $\mathrm{R} \$ 400,00$ \\
\hline $\begin{array}{c}\text { Ações } \\
\text { ambientais }\end{array}$ & $\begin{array}{c}\text { PMM, } \\
\text { Comunidade }\end{array}$ & Cidade & $\begin{array}{c}\text { Uma vez por } \\
\text { mês }\end{array}$ & Sensibilização & Campanhas & - \\
\hline
\end{tabular}

\section{CONCLUSÕES}

É possível gerir o descarte de óleo de cozinha, de maneira eficiente e com baixo custo, visto que os PEVs atuam na fase intermediária do processo - do recebimento à redistribuição - e, assim, armazenam por pouco tempo os resíduos no local. Mas, para que essa cadeia seja otimizada é necessária a divulgação e tomada de ações, que favoreçam o uso contínuo do espaço pela população.

Além disso, outras ferramentas de igual eficiência devem ser implementadas, como a utilização rotineira de coletores itinerantes, que possam atingir toda a extensão territorial da cidade de Manaus e favorecer as populações mais distantes, que possuem dificuldade de locomoção, a fim de consolidar o desenvolvimento sustentável na cidade de Manaus.

\section{REFERÊNCIAS}

[1] Câmara Municipal de Manaus. Lei Orgânica n 1.536 de 07 de dezembro de 2010. Dispõe sobre medida de reaproveitamento de óleo vegetal (cozinha) e seus resíduos e dá outras providências. Disponível em: http://www.cmm.am.gov.br. Acesso em 21/10/2017.

[2] Gil, Antonio Carlos. Como elaborar Projetos de Pesquisa. 4ㅡㅡㄹ Edição. São Paulo: Atlas, 2009.

[3] Thiollent, Michel. Metodologia da pesquisa-ação. 18ª Edição. São Paulo: Cortez, 2011.

[4] Paula, Maria Anunciada Nery Rodrigues de; Carvalho, Aurean de Paula. O gênero textual folder a serviço da educação ambiental. Revista Eletrônica em Gestão, Educação e Tecnologia Ambiental - Reget. v. 18, n. 2, Maio-ago., 2014.

[5] Prefeitura municipal de Manaus. Decreto Lei ${ }^{\circ} 815$ de 30 de março de 2011. Regulamenta a Lei $\mathrm{n}^{\circ} 1.536$ de 07 de dezembro de 2010, que dispõe sobre o reaproveitamento de óleo vegetal (cozinha) e seus resíduos. Disponível em: https://leismunicipais.com.br/prefeitura/am/manaus. Acesso em 21/10/2017. 


\section{Capítulo 5}

\section{Oxidação fotocatalítica de etileno: Uma estratégia para a redução do descarte de frutas e hortaliças}

\section{Alex Basso \\ Regina de Fátima Peralta Muniz Moreira \\ Humberto Jorge José}

Resumo: 0 etileno é um fitormônio que promove a maturação de frutos climatéricos. Quando presente em ambientes de transporte e armazenamento de frutas e hortaliças, o etileno pode ocasionar a aceleração da maturação e senescência causando o descarte destes produtos. 0 objetivo deste estudo foi avaliar o uso do processo de oxidação fotocatalítica na eliminação de etileno. Para tanto, tomates cereja (S. lycopersicum L.), utilizados como uma fruta modelo, foram inseridos em um recipiente hermeticamente fechado com circulação de ar através de um reator fotocatalítico, e a concentração de etileno e dióxido de carbono foi monitorada. Os reagentes e os produtos da reação foram identificados e quantificados utilizando um cromatógrafo gasoso acoplado a um espectrômetro de massas. 0 reator fotocatalítico mostrou-se eficiente para eliminação de etileno produzido por tomates cereja.

Palavras-chave: Processos oxidativos avançados. Segurança alimentar. Eteno. Espectrometria de massas. 


\section{INTRODUÇÃO}

O Atualmente, aproximadamente $45 \%$ do total de frutas e hortaliças produzidas mundialmente, ou seja aproximadamente 1,18 bilhão de toneladas, são descartadas anualmente durante o período de pós colheita devido à má conservação destes produtos (FAO, 2017). 0 uso de tecnologias que minimizem as perdas relacionadas a pós colheita, é amplamente investigado por ser uma questão de segurança alimentar principalmente devido à grande população mundial e a disponibilidade limitada de recursos naturais (FAO, 2017).

Uma forma de conservar a sua qualidade, e assim prolongar o tempo de prateleira dos produtos hortícolas e, consequentemente reduzir as perdas é eliminar o etileno de ambientes de armazenamento e transporte de frutas e hortaliças (KELLER et al., 2013; YE et al., 2015).

$\mathrm{O}$ etileno, $\mathrm{C}_{2} \mathrm{H}_{4}$, é um gás que atua como hormônio em plantas e produtos vegetais. É comumente conhecido por ser produzido por produtos vegetais como, por exemplo, por frutas climatéricas. Mas, o etileno também é gerado por fontes antropogênicas como, por exemplo, durante a combustão incompleta de hidrocarbonetos em motores de combustão interna ou aquecedores. Também pode ser gerado na combustão de carvão, óleo, gás natural e biomassa. Pode ser também encontrado em fumaça de cigarro, em vazamento de gases naturais, etc (GENARD, 2005; KELLER et al., 2013).

Em frutos climatéricos, como por exemplo o tomate cereja, a alta taxa de produção de etileno realizada pelo fruto ou a adição de etileno por outra fonte existente no ambiente de armazenamento e transporte e, consequentemente o contato deste gás com os frutos, promove uma série de processos fisiológicos que culminam na maturação acelerada, senescência e outros alterações que resultam na redução da qualidade destes frutos e consequentemente inviabilizando a sua comercialização.

Os valores de taxa de produção de etileno variam muito dependendo do tipo de fruto, desde valores abaixo de 0,1 até valores acima de $100 \mu \mathrm{L} \mathrm{kg}^{-1} \mathrm{~h}^{-1}$. A sensibilidade do tomate ao etileno também varia muito, partindo de concentrações de 0,01 até 5 ppmv de etileno. Estes valores já propiciam efeitos nos frutos, que geralmente culminam no descarte do mesmo (KELLER et al., 2013).

Com o intuito de controlar os problemas causados pela presença do etileno na pós-colheita de frutas e hortaliças, diversas tecnologias são amplamente utilizadas. Por exemplo: o armazenamento sob refrigeração, o uso de ventilação forçada, a utilização de adsorventes de etileno, a conservação em atmosfera controlada, a aplicação de coberturas comestíveis, etc., mas, estas técnicas podem resultar em um alto custo e até se tornarem inviáveis em muitos casos. Outras considerações, como por exemplo, no uso de luz UV-C para remover o etileno ocorre a formação de ozônio, gás tóxico que pode ocasionar danos na aparência de frutos e também ocasionar danos à saúde humana (DE CHIARA et al., 2015; KELLER et al., 2013; LOURENÇO et al., 2017; NIELSEN et al., 2015). Neste sentido, o desenvolvimento de um sistema de controle de etileno que opere a temperatura ambiente, com baixo custo, que não gere produtos indesejados, como o ozônio, e que não cause danos diretos aos produtos a serem conservados é um desafio atual nesta área.

A reação de fotocatálise ocorre na superfície de materiais semicondutores como o $\mathrm{TiO}_{2}$ que quando irradiado por uma radiação com comprimento de onda suficiente para ativação do fotocatalisador, resulta na transferência de um elétron da banda de valência para a banda de condução, gerando o par elétron $\left(\mathrm{e}^{-}\right)$ - lacuna $\left(\mathrm{h}^{+}\right)$, posteriormente uma serie de reações de redução e oxidação resultam na oxidação de etileno, formando dióxido de carbono $\left(\mathrm{CO}_{2}\right)$ e água (KELLER et al., 2013), de acordo com a equação (1).

$$
\mathrm{C}_{2} \mathrm{H}_{4}+3 \mathrm{O}_{2} \rightarrow 2 \mathrm{CO}_{2}+2 \mathrm{H}_{2} \mathrm{O} \quad \text { (Equação 1) }
$$

A utilização de uma tecnologia com baixos potencial poluidor e custo de implantação, e que seja eficiente como a fotocatálise, um processo oxidativo avançado que utiliza um catalisador que é ativado por luz (BASSO et al., 2018; MOREIRA et al., 2016), pode ser uma técnica promissora para o controle de etileno de ambientes de armazenamento e transporte de frutas e hortaliças.

O objetivo deste estudo foi avaliar a eficiência do uso da fotocatálise na eliminação de etileno produzido por frutas, usando como modelo tomates cereja (S. lycopersicum L.). 


\section{METODOLOGIA}

\subsection{OXIDAÇÃO FOTOCATALÍTICA DE ETILENO PRODUZIDO POR TOMATES}

Duas amostras de $500 \mathrm{~g}$ de tomate cereja cada foram colocadas em recipientes de vidro hermeticamente fechados. 0 volume de cada recipiente era de 3,25 litros. Um dos recipientes foi mantido fechado e o outro foi ligado ao reator fotocatalítico por uma tubulação (Figura 1 e 2).

Uma bomba de circulação de ar, com vazão volumétrica de $30 \mathrm{ml}$ por minuto foi utilizada para recircular o ar do recipiente através do reator fotocatalítico desenvolvido para eliminação de etileno. Foi utilizado um filme de fotocatalisador de aproximadamente 3,26 a $10^{-7} \mathrm{~m}$ de espessura e um valor de intensidade luminosa de $5 \mathrm{~W} \cdot \mathrm{m}^{-2}$. Estes valores foram previamente calculados levando em consideração a taxa de produção de etileno pela fruta e a taxa de oxidação fotocatalítica obtida. (BASSO et. al., 2017). Testes preliminares foram realizados para garantir o pleno funcionamento do sistema de circulação de ar, onde não foi observado vazamento de gás do sistema. Os tomates foram mantidos a temperatura ambiente $\left(25^{\circ} \mathrm{C}\right)$ durante 310 minutos.

Foram coletadas amostras de gases $(100 \mu \mathrm{l}$ cada) do interior do recipiente através de um septo de silicone posicionado na parte superior do recipiente. As amostras do gás do interior dos recipientes foram coletadas a cada 10 minutos por um período total de 310 minutos, usando uma seringa com um volume de $250 \mu \mathrm{L}$, e a concentração de etileno e dióxido de carbono foi determinada logo após a coleta utilizando o mesmo equipamento.

Valores de taxa de produção de etileno foram calculadas levando em conta o volume do recipiente utilizados, a concentração de etileno presente no interior do compartimento em contato com os tomates e a massa de fruta (tomate cereja), os resultados foram expressos em $\mu \mathrm{L}$ de etileno por kg de tomate por hora ( $\mu \mathrm{L} . \mathrm{kg} . \mathrm{h}^{-1}$ ) e os valores de concentração volumétrica de etileno e de dióxido de carbono foram expressos em partes por milhão (ppmv). Foi avaliada a taxa de produção de etileno e a eficiência na eliminação de etileno via oxidação fotocatalítica. Os experimentos foram realizados em duplicata e o valor médio obtido apresentado.

Figura 2 - Foto do aparato experimental usado para as reações de oxidação fotocatalítica de etileno

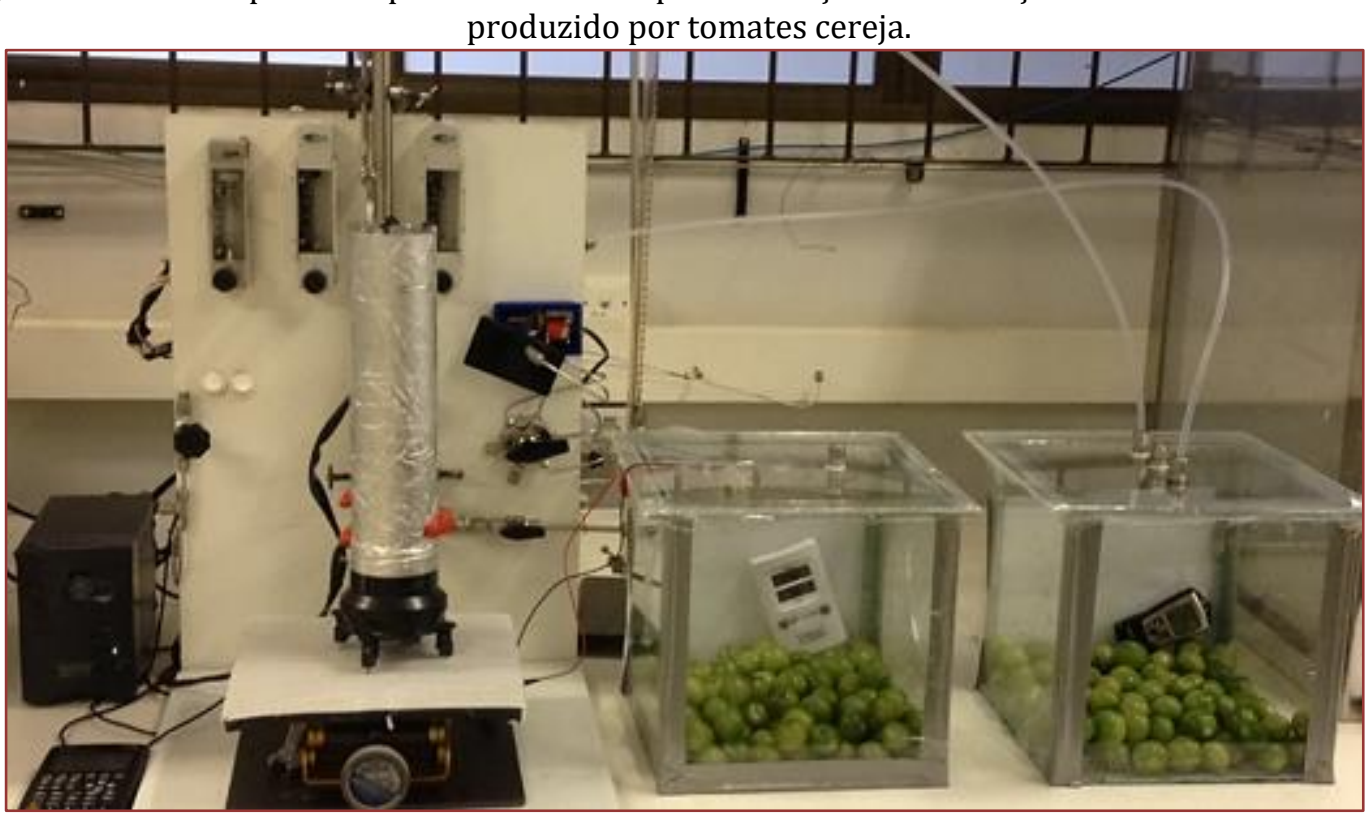

\subsection{AMOSTRAGEM E ANÁLISE DOS GASES}

Amostras de gases na entrada e saída do reator foram coletadas manualmente usando uma seringa tipo gastight de $250 \mathrm{~mL}$ (1725RN, Hamilton). A coleta dos gases foi realizada em tempos regulares e a análise dos gases foi realizada imediatamente após a coleta. 
Para determinação da concentração de gases foi utilizado um cromatógrafo gasoso acoplado a um espectrofotômetro de massas (GC/QP 2010 Plus, Shimadzu). No cromatógrafo foi utilizado uma coluna capilar do tipo camada porosa aberta tubular (PLOT), com 30 metros de comprimento, diâmetro interno de $0,32 \mathrm{~mm}$ e espessura de filme de $15 \mu \mathrm{m}$. A coluna capilar é composta por polímero divinilbenzeno, o qual atua como fase estacionária (Supel-Q-Plot, Supelco). Esta coluna foi utilizada por ser capaz de separar $\operatorname{Ar}\left(\mathrm{O}_{2}+\mathrm{N}_{2}\right)$ de dióxido de carbono e de etileno na mesma amostra, e à temperatura ambiente, facilitando assim a realização de experimentos que necessitem a detecção e quantificação de dióxido de carbono e de etileno simultaneamente.

A temperatura de operação do cromatógrafo gasoso foi mantida constante a $28^{\circ} \mathrm{C}$, e a temperatura do injetor a $120^{\circ} \mathrm{C}$. 0 injetor foi ajustado para operar no modo Split na razão de 1:10 utilizando o gás Hélio (99,99\% pureza, White Martins) como gás de arraste a uma vazão volumétrica constante de 1,33 $\mathrm{mL} \cdot \mathrm{min}^{-1}$. Os parâmetros do espectrômetro de massas foram: temperatura da interface $250^{\circ} \mathrm{C}$, energia de ionização $70 \mathrm{eV}$.

Inicialmente foram realizadas análises de aquisição dados através da busca e identificação de íons utilizando o modo de análise em varredura (SCAN) no intervalo de 10 a $200 \mathrm{~m} / \mathrm{z}$ (relação massa/carga do íon), para detecção de todos compostos presentes nas amostras. Nesta etapa, após obtido o cromatograma da análise de SCAN foi realizada uma busca utilizando a base de dados da biblioteca NIST, sendo identificados os picos referentes ao dióxido de carbono (tempo de retenção 1,4 minutos) e de etileno (tempo de retenção 1,75 minutos). Posteriormente, para identificação e quantificação de etileno e dióxido de carbono, foram monitorados os íons 28 e 44 respectivamente (nos respectivos tempos de retenção de cada composto) utilizando o modo de monitoramento de íon seletivo (SIM) que permite um aumento da sensibilidade do equipamento (BATTISTI et.al.,2016; HARRIS, 2012).

Os valores de concentração volumétrica de etileno e dióxido de carbono foram quantificados usando um padrão de calibração externo. O limite inferior de quantificação para o método utilizado era de aproximadamente $50 \mathrm{ppb}$ para etileno e dióxido de carbono, valores calculados de acordo com metodologia proposta por Harris (2012). 0 tempo total de cada análise era de dois minutos.

A metodologia de análise, a escolha da coluna cromatográfica, assim como o desenvolvimento do método cromatográfico foram realizados no Laboratório de Energia e Meio Ambiente da Universidade Federal de Santa Catarina. Para tanto foram otimizados os parâmetros de operação do cromatógrafo gasoso assim como os do espectrômetro de massas (BASSO et al., 2018; SCARATTI et al., 2018).

\section{RESULTADOS}

A Tabela 1 mostra os valores de concentração volumétrica de etileno dentro do recipiente com e sem circulação de ar através do reator fotocatalítico.

Tabela 1 - Concentração volumétrica de etileno e de dióxido de carbono com e sem (Controle) circulação de gás através do reator fotocatalítico (Fotocatálise), em função do tempo. Valores para 500g de tomates; volume do recipiente 3,2 litros. nd= não detectado.

\begin{tabular}{|c|c|c|c|c|}
\hline \multirow[t]{2}{*}{ Tempo } & \multicolumn{2}{|c|}{ Etileno (ppmv) } & \multicolumn{2}{|c|}{ Dióxido de Carbono (\%) } \\
\hline & Fotocatálise & Controle & Fotocatálise & Controle \\
\hline 0 & nd & nd & $0,4 \pm 0,1$ & $0,4 \pm 0,1$ \\
\hline $1 \mathrm{~h}$ & nd & $1,19 \pm 0,1$ & $0,49 \pm 0,1$ & $0,54 \pm 0,1$ \\
\hline $2 \mathrm{~h}$ & nd & $2,44 \pm 0,1$ & $0,86 \pm 0,1$ & $0,98 \pm 0,1$ \\
\hline $3 \mathrm{~h}$ & nd & $3,52 \pm 0,1$ & $1,21 \pm 0,1$ & $1,34 \pm 0,1$ \\
\hline $4 \mathrm{~h}$ & nd & $4,42 \pm 0,1$ & $1,65 \pm 0,1$ & $1,81 \pm 0,1$ \\
\hline $5 \mathrm{~h}$ & nd & $6,00 \pm 0,1$ & $1,81 \pm 0,1$ & $2,02 \pm 0,1$ \\
\hline
\end{tabular}

Nos testes realizados, a produção de etileno observada para tomates cereja foi de aproximadamente 7,08 $\pm 0,11 \mu \mathrm{L} . \mathrm{kg} \cdot \mathrm{h}^{-1}$ a $25 \pm 2{ }^{\circ} \mathrm{C}$. Esses resultados estão de acordo com a literatura, onde o tomate é classificado com uma mediana taxa de produção de etileno (FAGUNDES et al., 2015; KELLER et al., 2013).

Como se verifica da tabela 1 , não foi detectado etileno no reator fotocatalítico durante a reação. Por outro lado, foi detectado etileno no recipiente de controle em valores de até $6 \pm 0,1 \mathrm{ppmv}$.

A concentração volumétrica de dióxido de carbono no reator de fotocatálise foi pouco menor do que no 
recipiente de controle, possivelmente devido à redução na taxa de respiração do fruto, como consequência da ausência do etileno.

Devido a boa performance observada neste estudo preliminar da utilização da fotocatálise na oxidação de etileno, mais estudos serão realizados com o objetivo de avaliar o efeito do aumento de escala, bem como os parâmetros de qualidade dos frutos submetidos à eliminação de etileno via fotocatálise.

\section{CONCLUSÕES}

0 processo de oxidação fotocatalítica de etileno utilizando a fotocatálise pode ser utilizado para a manutenção de valores de concentração volumétrica de etileno próximo a zero, e assim prolongar o tempo de vida de prateleira de frutas, como por exemplo o tomate cereja, reduzindo assim o desperdício de alimentos ocasionado pela maturação acelerada dos frutos em contato com o etileno.

\section{REFERÊNCIAS}

[1] Basso, Alex., Soares, D., Moreira, R. F. P. M., Jose, H. J. Oxidação fotocatalítica de eteno em um reator tubular espiral de fluxo contínuo. IN: $19^{\circ}$ Congresso Brasileiro de Catálise e IX Congresso Mercosul de Catálise, 2017. Ouro Preto.

[2] Basso, Alex; de Fátima Peralta Muniz Moreira, Regina; José, Humberto Jorge. Effect of operational conditions on photocatalytic ethylene degradation applied to control tomato ripening. Journal of Photochemistry and Photobiology A-Chemistry, v. 367, p. 294-301, 2018.

[3] Basso, Alex; Battisti, Andrei Pavei; Moreira, Regina de Fátima Peralta Muniz; José, Humberto Jorge. Photocatalytic effect of addition of $\mathrm{TiO}_{2}$ to acrylic-based paint for passive toluene degradation. Environmental Technology, v. 9, p. 1-36, 2018.

[4] Battisti, A. P., Basso, Alex., Bustos, Y. N. L., Moreira, R. F. P. M., Jose, H. J. Desenvolvimento e avaliação de uma tinta fotocatalítica para degradação de tolueno gasoso. IN: III Simpósio sobre Sistemas Sustentáveis, 2016, Porto Alegre.

[5] De Chiara, M. L. V. et al. Photocatalytic degradation of ethylene on mesoporous $\mathrm{TiO}_{2} / \mathrm{SiO}_{2}$ nanocomposites: Effects on the ripening of mature green tomatoes. Biosystems Engineering, v. 132, p. 61-70, abr. 2015

[6] Fagundes, C. et al. Effect of active modified atmosphere and cold storage on the postharvest quality of cherry tomatoes. Postharvest Biology and Technology, v. 109, p. 73-81, nov. 2015.

[7] Fao. Food Loss and Waste Facts. Disponível em: <www.fao.org/save-food>. Acesso em: 11 ago. 2017.

[8] Genard, M. Ethy. A Theory of Fruit Climacteric Ethylene Emission. Plant Physiology, v. 139, n. 1, p. 531-545, 1 set. 2005.

[9] Harris, C. D. Análise Química Quantutativa. 8. ed. Rio de Janeiro: LTC, 2012.

[10] Keller, N. et al. Ethylene Removal and Fresh Product Storage: A Challenge at the Frontiers of Chemistry. Toward an Approach by Photocatalytic Oxidation. Chemical Reviews, v. 113, n. 7, p. 5029-5070, 10 jul. 2013.

[11] Lourenço, R. E. R. S. et al. Photodegradation of ethylene by use of TiO2 sol-gel on polypropylene and on glass for application in the postharvest of papaya fruit. Environmental Science and Pollution Research, v. 24, n. 7, p. 60476054, 12 mar. 2017.

[12] Moreira, R. F. P. M. ; Tenorio, M. R. ; Basso, Alex ; Jose, H. J. . Degradação fotocatalítica de efluentes líquidos da indústria de pescados utilizando fotocatálise heterogênea. IN: XXI Congresso Brasileiro de Engenharia Química, 2016, Fortaleza.

[13] Nielsen, M. G. et al. Removal of low concentration contaminant species using photocatalysis: Elimination of ethene to sub-ppm levels with and without water vapor present. Chemical Engineering Journal, v. 262, p. 648-657, fev. 2015.

[14] Scaratti, G ; Basso, Alex ; Landers, R ; Alvarez, P. J. J. ; Puma, Gianluca LI ; Moreira, Regina F. P. M. . Treatment Of Aqueous Solutions Of 1,4-Dioxane By Ozonation And Catalytic Ozonation With Copper Oxide (Cuo). Environmental Technology. P. 1-45, 2018.

[15] Ye, S. Y. et al. Photoelectrocatalytic decomposition of ethylene using $\mathrm{TiO}_{2} /$ activated carbon fiber electrode with applied pulsed direct current square-wave potential. Applied Surface Science, 2015 


\section{Capítulo 6}

Avaliação da adsorção do corante azul reativo Ci 222 com adsorvente de resíduo sólido industrial seco $e$ ativado quimicamente com $\mathrm{H}_{2} \mathrm{SO}_{4}$

\section{Gabrieli Coelho de Souza Heimoski Ribeiro}

\section{Catia Rosana Lange de Aguiar}

Resumo: 0 atendimento ao tripé sustentabilidade é uma preocupação constante, tanto pelas indústrias quanto pela sociedade em geral. 0 uso de materiais que até então eram considerados resíduos é cada vez mais uma realidade. 0 presente estudo demonstra a potencialidade de utilização do resíduo gerado na estação de tratamento de efluentes de uma indústria têxtil, neste caso, lodo de filtro prensa. Este material quando empregado como adsorvente do corante azul reativo CI 222 mostrou-se eficiente e promissor, uma vez que removeu aproximadamente $99 \%$ do corante em solução. Foram estudados também os modelos cinéticos e de isotermas e observou-se que o modelo cinético de pseudo segunda ordem e a isoterma de Langmuir regem o processo. Estes resultados indicam que o estudo com este material é de grande importância pois corrobora com melhores qualidades de efluentes tratados, bem com a redução de resíduos sólidos destinados para aterros.

Palavras-chave: Corantes; Resíduos Sólidos, Adsorção. 


\section{INTRODUÇÃO}

0 racional uso de água em indústrias têxteis vem sendo estudado por diversos pesquisadores, que objetivam manter a sustentabilidade ambiental bem como reduzir custos para a indústria. A indústria têxtil brasileira constitui uma atividade tradicional, tendo sido peça fundamental no desenvolvimento da política industrial, bem como de diversas outras atividades industriais no Brasil, que fornecem insumos direta ou indiretamente à indústria têxtil.

Pensando nas práticas de sustentabilidade, Manley et al. (2008), dizem que a química verde é o projeto, desenvolvimento, implementação de produtos químicos e processos para reduzir ou eliminar o uso e a geração de substâncias perigosas para a saúde humana e o meio ambiente.

A indústria têxtil é caracterizada por uma diversidade de tecnologias e processos de fabricação, utilizando variadas matérias-primas, fibras de origem animal e vegetal, fibras sintéticas, corantes, pigmentos e produtos químicos e um elevado consumo de água.

Na indústria têxtil, a etapa de beneficiamento é a que gera efluentes líquidos, os quais possuem certa concentração de corantes que podem causar impactos ao meio ambiente. De acordo com Vajnhandl et al. (2014), os processos de tingimento chegam a consumir mais de 100 litros de água por quilo de material processado, considerando-se todas as etapas de beneficiamento, sendo que $80 \%$ deste volume costuma ser descartado como efluente. Os efluentes têxteis possuem altas concentrações de sais, sólidos suspensos e principalmente cor (BLANCO et al., 2014) e estes efluentes têxteis geralmente são tratados por processos físico químicos, com coagulação e floculação, e biológicos, com degradação aeróbica e anaeróbica (Kim et al., 2015).

Segundo estudos de Reis et al. (2017), a adsorção pode ser compreendida como uma operação unitária de transferência de massa do tipo sólido-fluido, na qual se objetiva avaliar a capacidade de sólidos em concentrar em sua superfície determinadas substâncias contidas em soluções líquidas ou gasosas, variando de acordo com a massa de adsorvente utilizada e área superficial do mesmo. De acordo com Dotto et al. (2015), o método de adsorção se destaca, pois tem baixo custo de implementação e operação, alta eficiência, mínimo uso de energia, e simplicidade de operação.

Ressaltam-se, também, adsorventes oriundos de resíduos da própria indústria, como o lodo de esgoto sanitário proveniente das estações de tratamento de efluentes (PEREIRA; GIACOMONI; SOUZA, 2017). 0 potencial de valorização desse resíduo decorre pelo fato de ser um material inutilizado pela fábrica e, por ser gerado em grande volume, as empresas gastam muito para depositá-los em aterros específicos. Partindo desta premissa, o presente estudo apresenta opções de utilização de resíduos sólidos industriais em aplicações nobres, como a remoção de corantes residuais de efluentes têxteis.

\subsection{BJETIVO}

Avaliar o mecanismo de adsorção do corante azul reativo CI 222 com adsorvente obtido de lodo de filtro prensa seco a $60{ }^{\circ} \mathrm{C}$ e ativado com $\mathrm{H}_{2} \mathrm{SO}_{4}$.

\section{METODOLOGIA}

\subsection{OBTENÇÃO DOS ADSORVENTES}

Para a obtenção dos adsorventes aplicados no estudo, foi coletado o lodo desaguado do filtro prensa (LFP) na empresa Fiobras Ltda, localizada no município de Indaial - SC.

Uma fração de 40 gramas do lodo foi encaminhada para secagem. A mostra foi seca durante 24 horas em estufa em temperatura de $60^{\circ} \mathrm{C}$, triturada e acondicionada em dessecador.

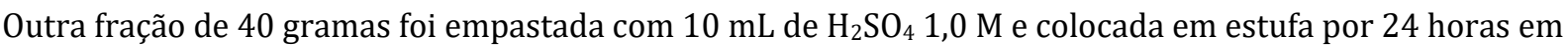
temperatura de $110{ }^{\circ} \mathrm{C}$. Após este tempo, a amostra foi colocada em estufa por 15 minutos em temperatura de $450^{\circ} \mathrm{C}$. Após este tempo a amostra foi lavada com água destilada até $\mathrm{pH}$ neutro, seca em temperatura de $60^{\circ} \mathrm{C}$ e então acondicionada em dessecador. 


\subsection{PROCESSOS DE ADSORÇÃO}

Para a determinação da eficiência de adsorção, foi utilizado o corante azul reativo CI 222 e os testes foram realizados em pH com valores iniciais de 5, 7 e 9, onde o pH da solução de corante a ser adsorvido foi corrigido empregando soluções de hidróxido de sódio e ácido acético. Os adsorventes utilizados foram o LFP seco a $60^{\circ} \mathrm{C}$ e o LFP ativado com $\mathrm{H}_{2} \mathrm{SO}_{4}$.

Inicialmente utilizou-se uma concentração de corante de $30 \mathrm{mg} / \mathrm{L}$ e adicionou-se $0,3 \mathrm{~g}$ do adsorvente no erlenmeyer o que representa uma concentração de $3 \mathrm{~g} / \mathrm{L}$ de adsorvente. Estando a solução pronta, as mesmas foram posicionadas em shaker durante 24 horas, sob rotação de $110 \mathrm{rpm}$. As amostras finais, retiradas após 24 horas, bem como as amostras iniciais foram analisadas em espectrofotômetro da marca Bel Photonics, modelo UV-M51, com comprimento de onda de $614 \mathrm{~nm}$, onde foi efetuada a leitura de absorbância das amostras. Para a determinação das concentrações foi efetuada uma curva de calibração para o corante. Os valores de absorbância da solução final obtidos aplicando essa metodologia foram utilizados para determinar a eficiência de remoção comparando-os com a solução inicial.

A capacidade de adsorção de cada um dos adsorventes foi calculada aplicando as equações 1 e 2 que descrevem, respectivamente, a concentração de corante no adsorvente e a eficiência de remoção.

$$
\begin{aligned}
& q e=[(\mathrm{Co}-\mathrm{Ce}) \mathrm{V}] / \mathrm{m} \\
& R \%=[(\mathrm{Co}-\mathrm{Cf}) / \mathrm{Co}] 100
\end{aligned}
$$

\section{Equação 1}

Equação 2

Onde, $\mathrm{q}_{\mathrm{e}}=$ concentração de corante no adsorvente no equilíbrio $(\mathrm{mg} / \mathrm{g}), \mathrm{C}_{\mathrm{o}}=$ concentração inicial de corante em solução $(\mathrm{mg} / \mathrm{L}), \mathrm{C}_{\mathrm{e}}=$ concentração de corante na solução no equilíbrio $(\mathrm{mg} / \mathrm{L}), \mathrm{V}=$ volume em $\mathrm{L}, \mathrm{m}=$ massa em $\mathrm{g}, \mathrm{C}_{\mathrm{f}}=$ concentração final de corante na solução $(\mathrm{mg} / \mathrm{L}), \mathrm{R}=$ eficiência de remoção de corante (\%).

Após a determinação do melhor resultado de eficiência para cada um dos adsorventes, foi selecionado o adsorvente LFP seco a $60^{\circ}$, com processo de adsorção em pH 7,0 para determinar a cinética e a isoterma de adsorção. Este adsorvente foi selecionado devido ao melhor resultado de eficiência de adsorção para o respectivo corante e devido a não necessidade de ativação química, o que corrobora com a redução de impactos ambientais, provenientes dos resíduos da ativação com o $\mathrm{H}_{2} \mathrm{SO}_{4}$.

Os processos de adsorção seguiram conforme a metodologia descrita para a determinação da eficiência, onde foram coletadas amostras de hora em hora até o final de 6 horas, onde o sistema já apresentou equilíbrio.

Para a determinação da cinética, foram empregados os modelos de pseudo primeira ordem e pseudo segunda ordem, de acordo com as equações 3 e 4, respectivamente.

$$
\begin{gathered}
\log _{10}\left(q_{e}-q_{t}\right)=\log _{10} q_{e}-k_{1} t / 2,303 \\
\frac{t}{q_{t}}=\frac{1}{k_{2} q_{e}^{2}}+\frac{1}{q_{e}} t
\end{gathered}
$$

Equação 3

Equação 4

Para a determinação das isotermas, as amostras consideradas para o cálculo foram as iniciais e finais, após 6 horas de adsorção. As concentrações de corante iniciais foram de 10, 20, 30 e $40 \mathrm{mg} / \mathrm{L}$. Foram aplicadas as equações da isoterma de Langmuir e da isoterma de Freundlich, conforme equações 5 e 6 , respectivamente.

$$
\begin{array}{cr}
\frac{\mathrm{C}_{\mathrm{e}}}{\mathrm{q}_{\mathrm{e}}}=\frac{1}{\mathrm{~K}_{\mathrm{L}}}+\mathrm{q}_{\mathrm{m}} \mathrm{C}_{\mathrm{e}} & \text { Equação 5 } \\
\operatorname{lnq}_{\mathrm{e}}=\ln _{\mathrm{F}}+\frac{1}{\mathrm{n}_{\mathrm{F}}} \ln _{\mathrm{e}} & \text { Equação 6 }
\end{array}
$$

onde, $\mathrm{q}_{\mathrm{e}}=$ concentração de corante no adsorvente no equilíbrio (mg/g), $\mathrm{q}_{\mathrm{t}}=$ concentração de corante no adsorvente no tempo $\mathrm{t}(\mathrm{mg} / \mathrm{g}), \mathrm{k} 1=$ constante de velocidade de adsorção $\left(\mathrm{min}^{-1}\right), \mathrm{k}_{2}=$ constante de 
velocidade de pseudo-segunda-ordem ( $\left.\mathrm{g} \mathrm{mg}^{-1} \mathrm{~min}^{-1}\right), \mathrm{K}_{\mathrm{L}}=$ constante de Langmuir, $\mathrm{q}_{\mathrm{m}}=$. quantidade máxima de soluto adsorvido para a formação de uma monocamada completa $\left(\mathrm{mg} \mathrm{g}^{-1}\right)$, $\mathrm{k}_{\mathrm{f}}$ e $\mathrm{n}_{\mathrm{f}}=$ constantes de Freundlich.

\section{RESULTADOS E DISCUSSÃO}

\subsection{EFICIÊNCIA DE ADSORÇÃO}

Após realização do processo de adsorção com os dois adsorventes em estudo, foram calculadas as eficiências de adsorção para todos os pH e estes resultados podem ser observados na figura 1.

Figura 1. Eficiência de adsorção do corante azul reativo CI 222 com lodo de filtro prensa seco a $60^{\circ} \mathrm{C}$ e ativado com $\mathrm{H}_{2} \mathrm{SO}_{4}$

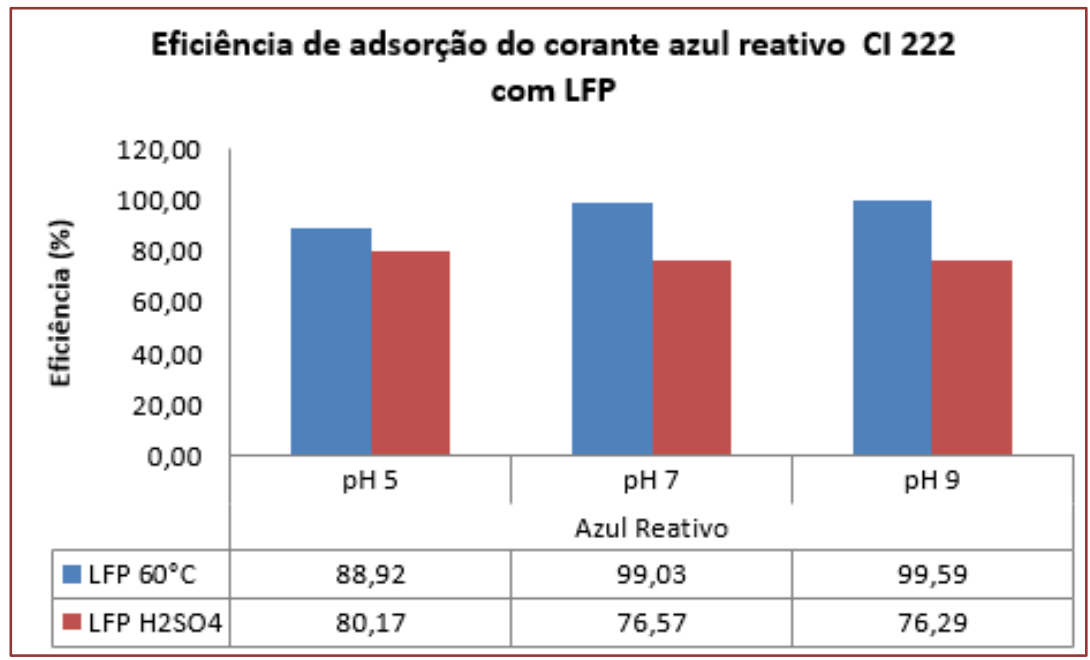

Observando a figura 1, é possível afirmar que o LFP é um excelente adsorvente para aplicação em remoção do corante azul reativo CI 222 de soluções aquosas. Uma excelente constatação é de que o LFP somente seco em temperatura de $60^{\circ} \mathrm{C}$ adsorve quase todo o corante em solução, não sendo necessário nenhum processo de ativação adicional ao adsorvente, já que a amostra modificada quimicamente $\operatorname{com} \mathrm{H}_{2} \mathrm{SO}_{4}$ apresentou remoção máxima de $80,17 \%$ do respectivo corante. Este resultado é promissor pois além de demonstrar a capacidade de uso do resíduo em questão, permite o uso com apenas um processo de secagem, não sendo necessário o uso de químicos, o que poderia inviabilizar a produção do adsorvente.

Como o resultado com o LFP seco a $60^{\circ} \mathrm{C}$ foi superior ao LFP modificado com $\mathrm{H}_{2} \mathrm{SO}_{4}$, a avaliação da cinética e das isotermas foi realizada com o adsorvente LFP seco a $60^{\circ} \mathrm{C}$.

\subsection{CINÉTICA DE ADSORÇÃO}

0 processo de adsorção do corante azul reativo CI 222 com o adsorvente LFP seco a $60{ }^{\circ} \mathrm{C}$ é regido pela cinética de pseudo segunda ordem, como pode ser observado na Figura 2. 
Figura 2. Cinética de pseudo primeira ordem (a) e Cinética de pseudo segunda ordem (b)

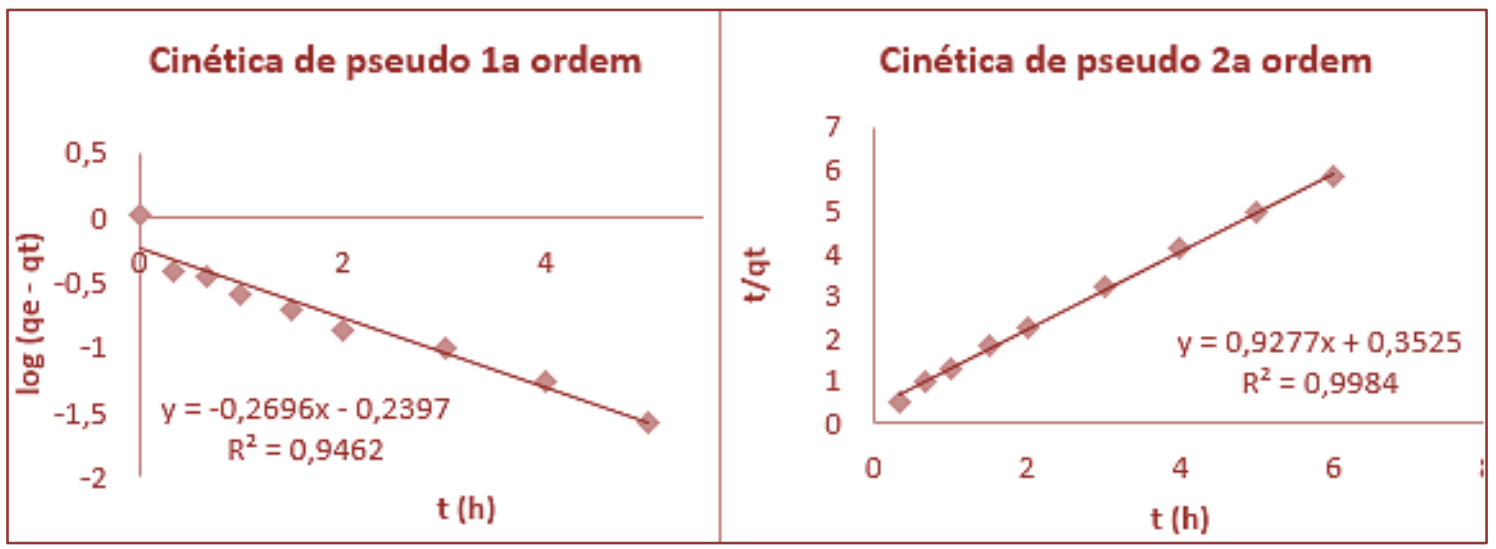

0 modelo matemático da cinética de pseudo segunda ordem considera que a etapa limitante do processo é a adsorção no sólido, com $\mathrm{k}_{2}=2,44 \mathrm{~g} \mathrm{mg}^{-1} \mathrm{~min}^{-1}$ envolvendo atrações eletrostáticas a partir da troca ou compartilhamento de elétrons entre o adsorvente e adsorvato. Sabe-se que o corante reativo é aniônico e esta característica pode ter favorecido este comportamento. Quando avaliada a constante de velocidade de adsorção no modelo de cinética de pesudo primeira orden, obteve-se o valor de $\mathrm{k}_{1}=0,6208 \mathrm{~min}^{-1}$.

\subsection{ISOTERMA DE ADSORÇÃO}

Após a determinação da cinética de tingimento, foram plotadas as isotermas de Langmuir e de Freundlich para o processo de adsorção em estudo, que podem ser analisadas na Figura 3.

Figura 3. Isotermas de adsorção de Langmuir (a) e Freundlich (b)

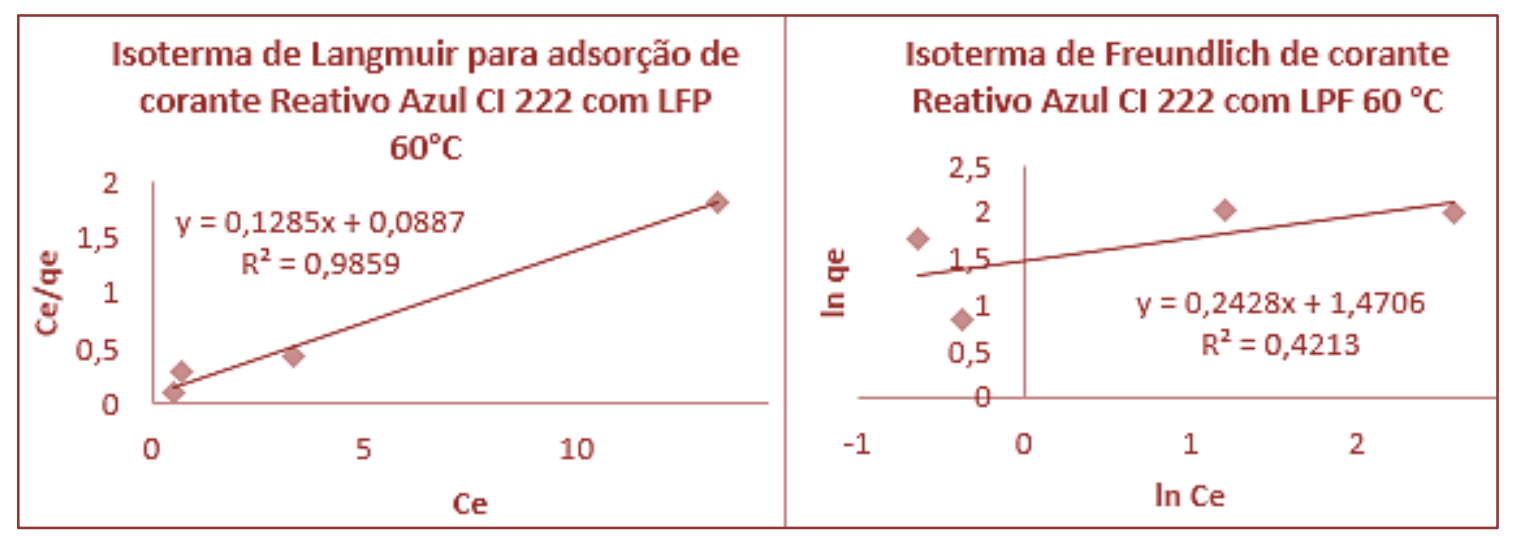

Observando as duas curvas, é possível afirmar por meio do resultado do ajuste de $\mathrm{R}^{2}$ que o modelo da isoterma de Langmuir é o que melhor se ajusta ao processo de adsorção com o corante e o adsorvente em estudo, onde a constante de Langmuir $\mathrm{K}_{1}=11,27$ e a quantidade máxima de soluto adsorvido para a formação de uma monocamada completa qm = 0,1285 mg/g. De acordo com Crini (2008), a teoria de Langmuir assume que a adsorção ocorre em sítios específicos e homogêneos na superfície do adsorvente, e cada sítio é responsável pela adsorção de apenas uma molécula de corante, não podendo ocorrer nenhuma adsorção adicional (apud DOTTO et al., 2011). 


\section{CONCLUSÃO}

Este estudo apresentou a potencialidade de utilização de um resíduo sólido produzido em uma indústria têxtil como adsorvente para remoção de corante de efluente, também de indústria têxtil. 0 processo de remoção do corante reativo azul CI 222 com o lodo filtro prensa mostrou-se eficiente e promissor. 0 adsorvente removeu aproximadamente $99 \%$ do corante em solução aquosa tendo sido apenas seco em temperatura relativamente baixa, indicando um processo limpo e seguro. 0 modelo de cinética de pseudo segunda ordem e o modelo da isoterma de Langmuir foram os modelos cinético e isotérmico com melhor ajuste ao processo de adsorção. Considerando os resultados obtidos, estes materiais devem ser estudados de forma mais aprofundada, tendo em vista ganhos como melhoria da qualidade do efluente tratado, redução de resíduos sólidos depositados em aterros industriais e redução de custos.

\section{REFERÊNCIAS}

[1] Blanco, J. et al. Photo-Fenton and sequencing batch reactor coupled to photo-fenton processes for textile wastewater reclamation: Feasibility of reuse in dyeing processes. Chemical Engineering Journal, v. 240, p. 469-475, 2014.

[2] Dotto, G. L.; Vieira, M. L.; Gonçalves, J. O.; Pinto, L. A. A. Remoção dos corantes azul brilhante, amarelo crepúsculo e amarelo tartrazina de soluções aquosas utilizando carvão ativado, terra ativada, terra diatomácea, quitiona e quitosana: estudos de equilíbrio e termodinâmica. Química Nova, v. 34, n. 7, p. 1193 - 1199, 2011.

[3] Kim, M. H.; Hwang, C.-H.; Kang, S. Bin; Kim, S.; Park, S. W.; Yun, Y.-S.; Won, S. W. Removal of hydrolyzed Reactive Black 5 from aqueous solution using a polyethylenimine-polyvinyl chloride composite fiber. Chemical Engineering Journal, v. 280, p. 18-25, nov. 2015.

[4] Manley, J. B. Anastas, P. T. CUE, B.W. Frontiers in Green Chemistry: meeting the grand challenges for sustainability in R\&D and manufacturing, Journal of Cleaner Production. 16, p. 743-750, 2008

[5] Pereira, I. C.; Giacomoni, M.; Souza, F. B. Reaproveitamento do lodo de esgoto sanitário como adsorventes de baixo custo para remoção de corante. 8o Fórum Internacional de Resíduos Sólidos, Curitiba, v. 1, n. 1, p.1-10, jun. 2017.

[6] Reis, M. A. et al. Avaliação da adsorção do corante violeta cristal empregando bagaço de malte como biosorvente. Anais do Congresso Regional de Iniciação Científica e Tecnológica em engenharia, p. 1-4, Ijuí, 2017.

[7] Vajnhandl, S.; VAHL, J. V. The status of water reuse in European textile sector. Journal of Environmental Management. V. 141, p. 29-35, 2014. 


\section{Capítulo 7}

Estimativa de captação da água de chuva do telhado do campus da faculdade Santo Agostinho em Vitória da Conquista - BA

Álvaro Magalhães Lessa

Emanuelle dos Santos Lemos

Paulo Sérgio Monteiro Mascarenhas

Resumo: As preocupações em relação à conservação e preservação da água são grandes, mas, a capacidade do ser humano em criar alternativas também é, e estas quando utilizadas fará com que a água seja mais bem distribuída mundialmente sem escassear. Um destes métodos é o reaproveitamento da água por reuso ou por água da chuva. 0 objetivo principal desse estudo é estimar o volume de água da chuva que poderia ser aproveitado do escoamento do telhado da Faculdade Santo Agostinho, a fim de reutilizar essa água para fins não potáveis, como uso em jardins, descargas, limpeza, entre outros, reduzindo-se assim, significativamente, os gastos da instituição com as contas de água. Os resultados apontam que existe a possibilidade de uma economia nos gastos com água pela instituição com a utilização da água capturada da chuva. Denotando uma preocupação e cuidado com o meio ambiente e a sustentabilidade ambiental.

Palavras chave: Água da chuva; Reaproveitamento; Sustentabilidade ambiental. 


\section{INTRODUÇÃO}

O risco de escassez de água vem sendo uma preocupação atual e assolando a população mundial. Atualmente, milhões de pessoas sofrem com a falta de água limpa suficiente para suprir suas necessidades básicas diárias, como beber, cozinhar, tomar banho, entre tantas outras utilidades que esse bem tem. Deve-se atentar não só para o consumo excessivo, mas também ao desperdício e às práticas utilizadas em casa e no trabalho. Ainda não houve uma mudança de hábito preponderante e que pudesse resultar numa expressiva redução de consumo de água, capaz de diminuir o problema de escassez (MARINOSKI, 2008).

De acordo com Fundo das Nações Unidas para a Infância (UNICEF) e da Organização Mundial da Saúde (OMS) revelam que quase metade da população mundial (2,6 bilhões de pessoas) não conta com serviço de saneamento básico e que uma em cada seis pessoas (cerca de 1,1 bilhão de pessoas) ainda não possui sistema de abastecimento de água adequado.

Dentro desse contexto surgiram vários estudos e ideias para solucionar, ou ao menos amenizar os problemas com a água. Uma delas é a captação para aproveitamento das águas pluviais para fins não potáveis, que por outro lado também proporcionaria a redução dos riscos de enchentes em regiões que possuem solos altamente impermeabilizados. A captação e aproveitamento da água da chuva é uma alternativa economicamente viável de substituição de fontes que pode atender demandas tanto potáveis quanto não potáveis (VIEIRA, 2002).

Uma forma comum de reaproveitamento de água a partir da chuva é o uso de cisternas para comportar a água e filtros para retirar os detritos até chegar ao sistema de bombeamento que a leve até a caixa d'água ou de forma mais simples utilizando o processo de limpeza por decantação sem utilizar aparelhagem e/ou pressão. Importante salientar que a água da chuva não é recomendada para ingestão e nem mesmo para banho, deve apenas ser utilizada para lavagens de carros, roupas, louças, regar jardins, utilizar em descargas, etc. (ABNT, 2007).

\section{REFERÊNCIAL TEÓRICO}

Segundo Moreira (2001), a importância da água é explicada pelo fato dela ser essencial ao ser humano, ao desenvolvimento econômico e à preservação do meio ambiente.

0 acesso à água doce é um dos problemas ambientais, econômicos e de saúde mais graves que afetam os países em desenvolvimento, incluindo o Brasil. A falta de água e sua poluição causam problemas graves de saúde pública, limitam o desenvolvimento econômico e agrícola e prejudicam os ecossistemas.

A manutenção de estoques de água potável para consumo humano (na agricultura, nas casas e na indústria) e para o equilíbrio dos ecossistemas é um desafio crescente para muitas sociedades. A alocação dos recursos hídricos para esses diferentes usos também se tem tornado bastante complexa. Algumas estimativas demonstram que no ano 2025, quando a população mundial provavelmente ter atingido a cifra de 8 bilhões de pessoas, toda a água acessível no mundo para consumo será necessária para atender às necessidades de produção agrícola, uso doméstico e industrial e para o atendimento das necessidades dos ecossistemas (Watson, 1998, p. 43).

A cidade Vitória da Conquista - BA possui uma população de 343.230 habitantes (IBGE, 2016), porém a Empresa Baiana de Águas e Saneamento - EMBASA não tem ampliado o fornecimento de água na mesma proporção do crescimento urbano. No ano de 2016 a cidade passa pelo quarto racionamento da sua história que desde 2012 com a baixa do volume de chuvas e o aporte populacional tem causado necessidade de racionar o abastecimento de água. Tendo em vista o fato da barragem de Água Fria II que abastece a cidade apresentar maior evaporação e menor captação devido aos longos períodos de estiagem na região.

A seca que atinge a Bahia, considerada a mais rigorosa dos últimos 50 anos, fez com que 228 prefeituras decretassem situação de emergência e provocou o cancelamento da festa de São João em ao menos três cidades. A celebração junina, a mais importante do ano no Estado, é realizada tradicionalmente em todos os 417 municípios baianos. A cidade de Vitória da Conquista, no sudeste da Bahia, passa pelo terceiro ano consecutivo de estiagem. Por causa da situação, ações foram programadas pelo governo do estado para evitar o racionamento de água no município e em outras cidades da região. Entre elas, estão a utilização de carros-pipa por meio do Programa (BRASIL, 2016). 
Mediante esse cenário faz-se necessário ações que visem alternativas para que a população das áreas atingidas possa ter água de qualidade e em quantidade suficiente para desempenhar suas funções diárias. Para suprir essa necessidade o uso de fontes alternativas de água é a solução mais viável. Dentre estas fontes destaca-se a captação das águas pluviais de telhados.

Alternativa essa que é detentora de duas principais qualidades, a de utilizar a água retida da chuva como forma de preservar a água potável. Mas também como uma maneira atenuadora de evitar os picos de enchentes. Essa já é uma forma milenar de utilização da água pelo homem, mas vem despontando como uma opção interessante. A utilização da água de chuva advém de mais de 2.000 anos onde a população já captava a água para utilização na agricultura, para seus animais e para fins domésticos (TOMAZ, 2003).

Rapoport (2004), a água de reuso é uma opção correta do ponto de vista ambiental, já que contribui para diminuição da captação e consequente redução nas vazões de lançamento de efluentes. Entretanto, para que possa ser utilizada deve-se levar em conta a questão da saúde pública. Existem padrões para reuso em alguns países do mundo que fazem do reuso de água, uma prática habitual. Entretanto, aqui no Brasil, estas práticas são preliminares.

\section{METODOLOGIA}

Para atingir os objetivos deste estudo foram coletos dados no site do INMET (www.inmet.gov.br) da distribuição do índice pluviométrico ao longo dos meses de setembro de 2014 a dezembro de 2015 na cidade de Vitória da Conquista - Bahia e selecionada imagem de satélite através programa Google Earth referente à área do Campus da FASAVIC. Esta imagem foi então transferida para o software AutoCAD 2016 Versão Estudantil, ajustada sua escala e calculada a área do telhado. Com os dados obtidos foi calculado o volume de água que poderia ter sido captado transformando os índices pluviométricos mensais em metros cúbicos e multiplicando este pela área do telhado. De acordo com os dados de consumo de água fornecidos pela instituição no período foram estimados impactos econômicos dessa captação em relação ao desperdício de água potável. Também foram feitas análises econômicas referentes à redução do custo no qual a instituição seria beneficiada.

\section{RESULTADOS E DISCUSSÃO}

A Faculdade consumiu entre setembro de 2014 a dezembro de 2015 um total de $660,67 \mathrm{~m}^{3}$ de água com um custo de $\mathrm{R} \$ 16.155,72$. Neste mesmo período teria sido possível captar $792,14 \mathrm{~m}^{3}$, que seria equivalente a $\mathrm{R} \$ 19.064,93$, isso somente em parte do telhado da instituição, ou seja, com o uso de captação de água da chuva pelo telhado, a faculdade poderia até se tornar autônoma, através da instalação de um sistema para captação da água, e não teria gastos com este recurso durante o ano, exceto o volume de água tratada destinada aos bebedouros. Este valor de mais de 16 mil reais poderia ser então repassado para os alunos em forma de viagens para projetos de extensão e/ou softwares na área de informática e outros vários usos possíveis.

\section{CONCLUSÃO}

O estudo mostra indícios de que é possível o armazenamento de água de chuva dos telhados para utilização para limpezas e irrigação de jardins, representando economia e conscientização para o aproveitamento hídrico. Também é notável a quantidade de água que pode ser aproveitada, trazendo uma economia que paga os custos do projeto em pouco tempo. Com o projeto realizado se contata que existe a possibilidade de uma política pública voltada para a gestão hídrica sustentável que favorece não somente ao meio ambiente, mas a saúde financeira das empresas e instituições, sejam elas públicas ou privadas que adotem a prática. 


\section{REFERENCIAS}

[1] Abnt. Associação Brasileira de Normas Técnicas. NBR: 15527: água de chuva: aproveitamento de coberturas em áreas urbanas para fins não potáveis: requisitos. São Paulo: [s. n.], 2007.

[2] Brasil. Ministério da Agricultura Pecuária e do Abastecimento. Disponível em: http://www.inmet.gov.br/portal/. Último acesso em outubro de 2016.
[3] Ibge.
Disponível
em:

http://www.cidades.ibge.gov.br/xtras/perfil.php?lang=\&codmun=293330\&search=bahia|vitoria-daconquista|infograficos:-informacoes-completas.> Último acesso em 20/06/2016.

[4] Marinoski, A. K. Ghisi, E. Aproveitamento de água pluvial para usos não potáveis em instituição de ensino: estudo de caso em Florianópolis-SC. Ambiente Construído, Porto Alegre, v. 8, n. 2, p. 67-84, 2008.

[5] Moreira, R. M. Alocação de recursos hídricos em regiões semi-áridas. Dissertação de Mestrado em Ciências em Engenharia Civil - Universidade Federal do Rio de Janeiro, COPPE, 2001.

[6] Rapoport, B. Águas cinzas: caracterização, avaliação financeira e tratamento para reuso domiciliar e condominial. Dissertação de Mestrado - Escola Nacional de Saúde Pública do Rio de Janeiro, 2004.

[7] Tomaz, P. Conservação da água. São Paulo Parma. 1998.

[8] Watson, Robert T. et al. Protecting our Planet, Securing Our Future: Linkages among global environmental issues and huma needs, publicação do Pnuma - Programa das Nações Unidas para o Meio Ambiente, Banco Mundial/Nasa, novembro de 1998.

[9] Vieira, Paulo Freire e Weber, Jaques (orgs) Gestão de Recursos Naturais Renováveis e Desenvolvimento. São Paulo: Cortez Editora, 2002. 


\section{Capítulo 8}

Percepção ambiental hídrica: Eirunepé na calha do rio Juruá, Amazonas

\section{Delsinei Vieira da Costa}

Carlos Henrique Rodrigues Gomes

Katia Viana Cavalcante

Valdiney Ferreira de Almeida

William Vieira de Lima

Resumo: No Brasil, as políticas públicas voltadas aos recursos hídricos têm sido formuladas de modo a promover uma gestão compartilhada das águas, sendo a Política Nacional de Recursos Hídricos o principal marco jurídico-institucional nesse campo. 0 objetivo do trabalho foi identificar como ocorre a governança da água na cidade de Eirunepé, de forma a contribuir com o debate teórico metodológico sobre o uso de recursos hídricos em cidades da Amazônia, uma vez que no imaginário das populações locais este é um bem que não irá faltar, devido à existência e abundância de grandes rios na região. Além disso, buscou-se diagnosticar a percepção da população sobre questões relacionadas à gestão das águas no município. Com o objetivo de compreender as interrelações no ambiente, a pesquisa apoiou-se na abordagem teórica da complexidade sistêmica. Para isso, foram aplicadas entrevistas, que permitiram perceber o conhecimento dos moradores no que concerne às questões ambientais, principalmente relacionadas à administração dos recursos hídricos locais.

Palavras Chave: Percepção Ambiental; Recursos Hídricos; Eirunepé. 


\section{INTRODUÇÃO}

A degradação dos recursos hídricos é um dos temas mais caros ao debate ambiental contemporâneo. A problemática relacionada à água compreende um vasto campo de tensões e conflitos que envolvem múltiplos atores e interesses setoriais pelo uso desse recurso natural. No Brasil, as políticas públicas voltadas aos recursos hídricos têm sido formuladas de modo a promover uma gestão compartilhada das águas, sendo a Política Nacional de Recursos Hídricos o principal marco jurídico-institucional nesse campo.

O padrão de estruturação urbana que se estabeleceu na cidade de Eirunepé provocou uma significativa degradação de seus recursos hídricos, com a ocupação intensiva e irregular de áreas próximas a igarapés e ao rio. A contaminação, a diminuição da cobertura vegetal, a ocupação e a ausência de rede coletora e de tratamento de esgotos, são fatores que podem provocar alterações no ciclo da água. Uma situação exemplar desse fenômeno é a dimensão assumida pela transformação das enchentes em inundações, problema que vem tornando-se recorrente no espaço urbano da cidade. Neste contexto, buscou-se identificar como ocorre a governança da água na cidade de Eirunepé, de forma a contribuir com o debate teórico metodológico sobre o uso de recursos hídricos em cidades da Amazônia, uma vez que no imaginário das populações locais este é um bem que não irá faltar, devido à existência e abundância de grandes rios na região. Além disso, buscou-se diagnosticar a percepção da população sobre questões relacionadas à gestão das águas no município. A abordagem aqui desenvolvida tem como foco analítico o conceito de governança, que se baseia na premissa de ser resultado da ação de múltiplos atores, dentre os quais o Estado que, sem dúvida, é o mais importante. Configura-se assim o exercício deliberado e contínuo de desenvolvimento de práticas cujo foco analítico está na noção de poder social que media as relações entre estado, sociedade civil, de forma a ampliar os mecanismos de democracia participativa. 0 tema "governança das águas" insere-se nas novas tendências da gestão de políticas públicas, principalmente quando se considera a possibilidade de incentivar novos atores sociais com intuito de promover melhoria na gestão e avançar na democratização desses processos.

A abordagem da governança ambiental possui história recente, fortalecida a partir de meados da década de 1980, e refere-se a formas de governar os recursos naturais envolvendo diferentes atores - governo, empresariado e o espectro ampliado da sociedade civil. 0 sistema de governança permite repensar as formas de gestão. Os elementos que o compõem são: fator político, o fator credibilidade e a dimensão ambiental. A literatura sobre o tema enfatiza a governança da água, como a realizada por meio da participação, envolvimento e negociação de multiatores (multi-stakeholders), da descentralização, transferindo poder para o governo local (empowerment), da unidade de gestão por bacia hidrográfica, por exemplo, e de mecanismos para resolução dos conflitos (Solanes e Jouralev, 2006; Castro, 2007).

A água é um elemento natural essencial à vida no planeta, um recurso limitado e que possui papel significativo no desenvolvimento econômico e social de uma região. Contudo, é observada sua contaminação em áreas urbanas e rurais, pois há uma concepção errônea por parte das populações de que as reservas de água são infinitas, principalmente por aqueles que a obtém com facilidade. Na Conferência de Estocolmo em 1972 o tema da escassez e contaminação de águas passou a vigorar dentre as problemáticas ambientais. Outras reuniões sucessivas ocorreram, sendo relevante World Water Concil (Conselho Mundial da Água), de 1996, a Convenção sobre Cursos de Águas Internacionais, de 1997 e, a Conferência das Nações Unidas para o Meio Ambiente e Desenvolvimento, ou ECO - 92, realizada no Rio de Janeiro. 0 documento oficial desse último evento trouxe capítulos que expressam as preocupações com questões relacionadas à água, e em 2013 foi consolidado pela UNESCO o Ano Internacional de Cooperação pela Água.

A compreensão da gestão pública das águas no Brasil foi marcada por uma mudança de paradigma. Em 1934 foi criado, o Código das Águas (Decreto 24.643, de 10/07/1934), marco regulatório que possibilitou a expansão do setor de energia hidroelétrica no país. A administração da água, segundo o Código, ocorreu de forma centralizada nos governos federal e estadual e esteve focada na gestão quantitativa, na concessão de uso para geração de energia e, posteriormente, para irrigação de projetos públicos (FIGUEIRÊDO, 2008). Todavia, em virtude dos amplos debates ambientais sobre a situação de desperdício e contaminação da água, ocorreu uma mudança no pensamento, em que não mais se concebia uma gestão dos recursos hídricos centralizada, mas uma gestão integrada e participativa.

A Constituição de 1988 seguida da Política Nacional de Meio Ambiente, assinala ao poder público e à coletividade o dever de proteger os recursos ambientais, dentre eles a água, reconhecendo que a educação ambiental é um instrumento valioso para participação da comunidade na defesa destes recursos.

Entretanto, apesar destas ações, as populações locais ainda participam da gestão de recursos hídricos de 
forma pontual e restrita, o que interfere na evolução da ação da sociedade civil na gestão ambiental, revelando a falta de hábito da população em participar de processos decisórios, embora a participação seja legalmente assegurada. Lima (2003) argumenta que essa situação ocorre em virtude da desarticulação em relação ao funcionamento burocrático das discussões públicas, bem como do não envolvimento do cidadão comum (que não é técnico nem profissional da área). Nesse sentido, é necessário envolver as populações locais e consultá-las, haja vista a gestão das águas inferirem em seu cotidiano, sendo influenciado pelas decisões tomadas.

Apesar de toda a legislação proposta, muito pouco se tem feito em termos de ações para minimizar os problemas ambientais, dentre eles um dos mais relevantes é o da contaminação das águas e sua escassez, de forma que o envolvimento das populações locais nos processos de tomada de decisões nas questões de gerenciamento de recursos hídricos é de vital importância.

A percepção ambiental é um processo mental de interação do indivíduo com o espaço ocorrendo a partir dos estímulos externos, por meio dos sentidos e mecanismos cognitivos (motivações, necessidades, conhecimento prévio, julgamento e expectativas) (DEL RIO e OLIVEIRA, 1999).

Ao observar as interfaces do ser humano com o ambiente, Tuan (1980 p.05) considera a percepção como resposta dos sentidos aos estímulos externos e como atividade proposital na qual certos fenômenos são claramente registrados enquanto outros retrocedem para a sombra e são bloqueados. Portanto, o percebido tem valor para as pessoas por estar intimamente ligado aos interesses, às necessidades e às experiências vividas.

Destarte, a experiência é conceitualizada a partir de um sistema estrutural de crenças, pessoais e socioculturais, uma vez que os indivíduos desenvolvem a topofília (relação com os lugares ou ambiente físico) bem como ações de topocídio, (destruição das paisagens naturais ou culturais). Esses conceitos apresentam grande significado para o futuro das questões ambientais, pois os seres humanos têm contribuído com danos muitas vezes irreversíveis. Entretanto, as ações de topo- reabilitação (restauração ou reabilitação dos conjuntos ambientais) vêm proporcionando a melhoria na qualidade de vida do planeta. (ROCHA, 2003).

A investigação da percepção nas relações ser humano-ambiente contribui para a utilização menos impactante dos recursos ambientais, possibilitando o estabelecimento de relações mais harmônicas entre o homem e o meio (LIMA, 2003). Deste modo, estudar a percepção e a relação que as populações locais têm com seu entorno, permite compreender seu nível de abstração e comprometimento com questões relacionadas ao meio ambiente

\section{DESENVOLVIMENTO}

O presente estudo utilizou-se de uma abordagem qualitativa que vislumbrou conhecer a percepção da governança da água na zona urbana do município de Eirunepé-AM (Figura 1). 0 município está inserido na região norte do Estado, distante da capital amazonense em linha reta cerca de $1.160 \mathrm{~km}$ e tem as seguintes coordenadas de localização geográfica: $06^{\circ} 39^{\prime} 37^{\prime \prime} \mathrm{S}$ de Latitude e a 6952'25”W de Longitude, com uma área estimada em $16.079 \mathrm{~km}^{2}$, a $130 \mathrm{~m}$ acima do nível do mar.

Com o objetivo de compreender as inter-relações no ambiente, a pesquisa apoiou-se na abordagem teórica da complexidade sistêmica, elucidada por Morin (2003, p 44), constituindo assim, a base lógica da pesquisa. Essa fase foi ancorada em variáveis de pesquisa exploratória, que para Gil $(1999$, p. 43) são desenvolvidas com o objetivo de proporcionar visão geral, de tipo aproximativo, acerca de determinado fato.

Deste modo, escolhemos a técnica de entrevistas por oferecer vantagem no levantamento de dados tais como: conhecer a atitude, preferência e opinião do entrevistado sobre determinado assunto; eficiência na obtenção de dados que dizem respeito ao comportamento humano; os dados obtidos podem ser classificados e quantificados, entre outras. Nesse sentido foram aplicadas entrevistas aos gestores da secretaria municipal de educação e saúde; ao gestor da companhia de saneamento básico - Cosama; ao pároco da igreja católica (devido a campanha da fraternidade 2017 abordar a temática ambiental) ao coordenador administrativo e professores do Instituo Federal do Amazonas - Ifam, a vinte (20) famílias residentes na cidade distribuídas por setor conforme a figura abaixo, escolhidas aleatoriamente e que se disponibilizassem para as entrevistas, sendo entrevistadas um total de cinco famílias por setor. 
Figura 1 - Imagem do Google Earth da cidade de Eirunepé. Setores de coleta das entrevistas.

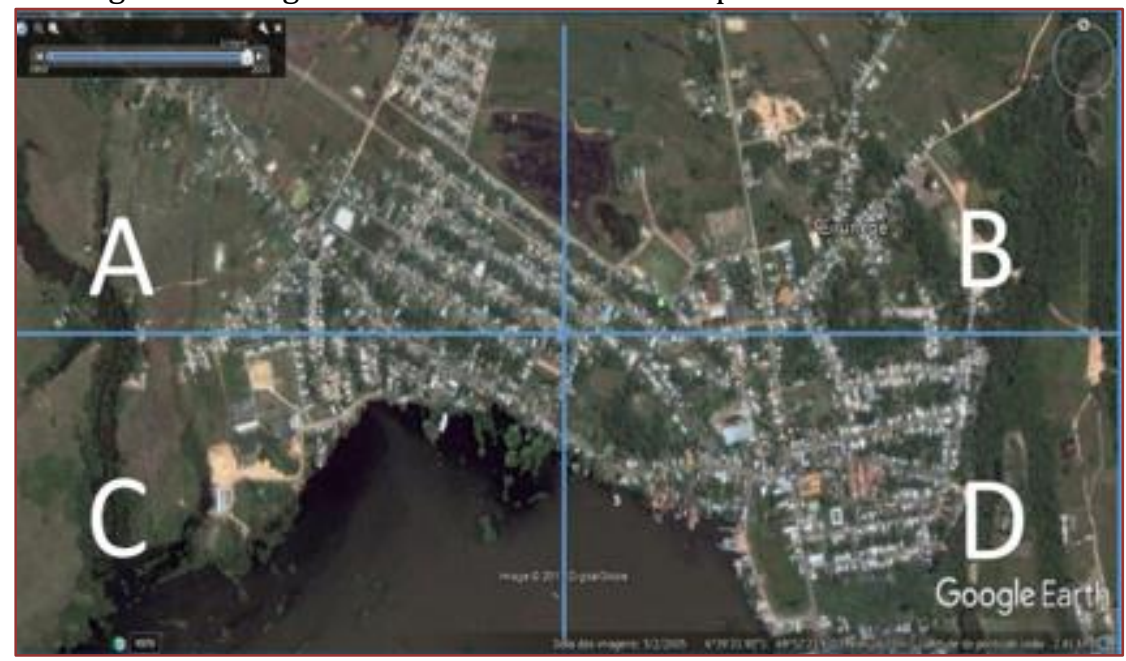

Fonte: Imagem do Google Earth trabalhada no Lab. Cartografia do IFAM maio/2017.

Em toda a cidade de Eirunepé como em outras cidades da calha do Rio Juruá, entre os usuários da água fornecida pela Companhia de Saneamento do Amazonas (Cosama) há um sentimento de rejeição quanto a aceitabilidade da água distribuída pela companhia de saneamento básico. Alguns moradores preferem utilizar outras fontes de recursos hídricos, como poços artesianos particulares, explorando o lençol freático de maneira inadequada e, em muitos casos sem autorização.

Mesmo com o especialista explanando sobre o caso de contaminação de poços artesianos a Cosama tem atendido a um público de 4.727 ligações. A pesquisa apontou que uma das causas da rejeição da água da captação superficial por parte dos usuários está relacionada à cor da água do Rio Juruá, que, por transportar sedimentos à jusante da sua nascente, demonstra a coloração barrenta.

De acordo com informações do agente da Cosama do município de Eirunepé-AM, a empresa está atuando na cidade a mais de 30 anos e mantém dois sistemas de abastecimentos de água - Captação Superficial e o de Captação Subterrânea, esses dois processos são dependentes e complementares.

A captação superficial utiliza bombas de $40 \mathrm{cv}$, instaladas em uma balsa flutuante localizada à margem esquerda do Rio Juruá. A localização da balsa depende do nível das águas do rio sendo deslocada de acordo com a vazão do Lago dos Portugueses, acompanhando o pulso anual da água do Rio Juruá e como estratégia para evitar que o motor bomba sugue dejetos trazidos pela correnteza do rio e advindos do Lago.

Segundo Informações da laboratorista da Cosama em Eirunepé, responsável pelas análises bacteriológica, físico-química, nas amostragens de coleta e distribuição, na capitação e na ponta de rede, a captação superficial passa por vários processos para que se atinja a potabilidade adequada ao consumo humano: processo de equilibração de ph, processo de floculação, processo de decantação, processo da filtração e processo da cloração. Os resultados das amostras de água têm atendido rigorosamente aos padrões estipulados pela Agência Nacional de Vigilância Sanitária (ANVISA) na Portaria 2.914 de 12 de dezembro de 2011, a qual descreve a obrigatoriedade do processo de tratamento de água para o consumo humano.

0 agente da Cosama informou ainda que não existe informativos a população sobre o processo de tratamento da água que é distribuída pela Companhia às suas residências.

Outro órgão que participar da gestão das águas no município é a Secretaria de Saúde do município mediante o setor de fiscalização da qualidade da água dos poços artesianos particulares da cidade de Eirunepé - VIGIÁGUA.

O setor possui um cadastro dos poços existentes na cidade, tanto os de uso individual (para uma residência) como os de uso coletivo (para várias residências). No ano de 2015 havia 350 poços, em 2016 são registrados 400 poços particulares, muitos deles perfurados sem autorização. Até o mês de maio havia ocorrido um acréscimo de $30 \%$ na abertura de novos poços particulares, contribuindo para o número elevado de poços contaminados. Esta contaminação se dá pela perfuração em locais inapropriados, próximos a fossas sépticas, e também dependendo do pulso das águas do Rio Juruá, pois no período 
enchente o nível de contaminação da água dos poços rasos é ainda maior que os níveis encontrados em período da seca.

Os registros de analise da qualidade da água de poços apontam que em 2015 90\% da captação subterrânea estavam contaminadas com coliformes totais e fecais. No entanto, após intensificação das campanhas de fiscalização da infraestrutura e das campanhas informativas sobre aplicação de hipoclorito na dosagem recomenda pela ANVISA (Portaria $\mathrm{n}^{\underline{0}}$ 2.914/2011), ocorreu um declínio nesse percentual para o ano de 2016, ficando entorno de 60\% das captações com contaminação.

As campanhas informativas são realizadas via rádio e visita da equipe de fiscalização nas residências para avaliar a qualidade da água. Sendo abordadas as seguintes recomendações: Realizar limpeza e desinfecção dos reservatórios com frequência mínima de 06 (seis) meses; Realizar sistematicamente a desinfecção da água, com hipoclorito de sódio, conforme recomendado pela ANVISA; Realizar limpeza e desinfecção das cubas e torneiras dos bebedouros semanalmente, assim como dos garrafões de água, todas às vezes antes de substituí-los; Suspender imediatamente a utilização da água para consumo humano e adotar medidas necessárias à normatização do parâmetro. As escolas estaduais e municipais existentes na cidade de Eirunepé utilizam captação subterrânea como fonte de água. Entretanto não possuem informativos e ou campanhas educativas sobre o uso e cuidado com o recurso. A Coordenadora Estadual de Ensino da Secretaria de Estado de Educação do Amazonas (Seduc) informou que utiliza poços artesianos, pois não há confiança da sociedade de Eirunepé na água fornecida pela Cosama, tanto na qualidade como na continuação de fornecimento, devido a várias interrupções do sistema de abastecimento. Durante as visitas nas escolas detectamos desperdício de água nos banheiros e nos bebedouros.

O ano de 2017 tem na Campanha da Fraternidade, o tema "Biomas Brasileiros e Defesa da Vida", todavia as igrejas e os grupos católicos não realizam ações práticas que promovam a difusão e/ou diálogos sobre temas ambientais como os recursos hídricos. Na igreja também existe poço artesiano.

Na pesquisa com as famílias, detectou-se que $60 \%$ dos entrevistados possuem apenas o ensino fundamental incompleto e $40 \%$ possuem o ensino médio, comprovando a baixa escolaridade dos moradores.

A partir das observações in loco, percebeu-se que a maioria dos poços, encontra-se em condições não recomendadas pela Agencia Nacional de Águas - ANA, pois esse tipo de poço artesiano deve ser coberto para que se evite a entrada de água contaminada da superfície (que pode torná-la imprópria para o consumo humano), e a queda de objetos e animais em geral. No que diz respeito ao tratamento da água com o hipoclorito, os moradores afirmaram que fazem uma vez ao ano, outros afirmaram não fazerem uso. 0 tratamento é apontado por sanitaristas como de fundamental importância para a limpeza da água a ser consumida, o produto é distribuído pela secretaria de saúde do município.

As famílias entrevistadas consideram a água de suma importância para a existência humana, sendo comuns algumas afirmações a seguir: "A água é $o$ liquido precioso" (residente do setor A); "Sem água $a$ gente não pode viver" (residente do setor B); "Á água é indispensável na vida de todos os seres humanos" (residente do setor D). A partir das afirmações, percebe-se que os moradores possuem uma relação de dependência a água, usando-a para o consumo doméstico, para lazer, mas observa-se que $100 \%$ das famílias desconhecem o significado dos termos Recursos Hídricos e Gestão de Recursos Hídricos, de modo que era latente a falta de informação sobre uso, captação e tratamento, qualidade da água.

Os entrevistados se consideram bem informados sobre questões relacionadas ao meio ambiente. Aqueles que não se achavam bem informados deram as seguintes explicações: "Nunca estudei sobre isso" (residente do setor C); "Faltam informações sobre o assunto" (residente do setor D).

Mesmo se considerando bem informados, os moradores consideram importante receberem mais informações, segundo pode ser visualizada nas seguintes afirmações: "Se as pessoas fossem melhor informadas cuidariam melhor da água "(residente setor D); “A gente quando sabe de um assunto pode ensinar outros" (residente setor $\mathrm{C}$ ).

Sobre quais as melhores formas de receber informações sobre questões ambientais, houve divergência entre os que preferirem palestras, folhetos e aqueles que optaram pela televisão.

Do ponto de vista ambiental, a gestão dos recursos hídricos na cidade de Eirunepé é considerada crítica, resultado de um conjunto de fatores que envolvem desde a ocupação irregular das margens do rio, dos lagos e dos igarapés, a precariedade dos serviços prestados e até mesmo a omissão do poder público, seja em razão da ausência de planos eficazes, seja em decorrência de uma ação fiscalizadora quase sempre inadequada e impotente. A reversão desse quadro de degradação urbano-ambiental do uso do recurso 
hídrico é bastante complexa e demanda o fortalecimento de ações relacionadas à construção social da governança para articular agendas, canais de participação e parcerias de sujeitos e potencialidades em torno de uma governança participativa o envolvimento das populações locais nos processos de tomada de decisões nas questões de gerenciamento de recursos hídricos.

\section{CONCLUSÕES}

Possível perceber a importância da visão sistêmica e, para a construção da governança local dos recursos hídricos, suas relações e conseguindo uma visão holística da realidade. 0 desenvolvimento sustentável tem como princípio a ideia de uma rede de agentes e elementos que interagem e geram consequências para toda a sociedade. Portanto, a visão e o enfoque sistêmico estão alinhados com a ideia da sustentabilidade, servindo como alicerce para a compreensão de toda a complexidade que envolve o planeta.

Nota-se a importância dos estudos processuais para o gerenciamento de recursos hídricos, de modo a torna-se imprescindível estudos sistêmicos que analisem os diversos elementos importantes para a governança dos recursos hídricos nos municípios da Amazônia.

A percepção ambiental sobre os recursos hídricos na cidade de Eirunepé mostrou que existe uma relação forte entre os residentes e os recursos hídricos locais, no entanto uma relação de desconfiança da população com a companhia de saneamento básico.

Observou-se ainda, que mesmo havendo disponibilização de duas fontes hídricas de abastecimento (poços, rios), ainda há problemas de falta de água para o consumo. Esse fato é preocupante, pois a grande demanda de água e sua baixa disponibilidade geram a proliferação de poços clandestinos, o que compromete as condições do lençol freático de vida das populações locais.

Percebeu-se também que, não há divulgação e/ou campanhas locais sobre o uso o tratamento do abastecimento de água na cidade.

\section{REFERÊNCIAS}

[1] Castro, J. E. (2007). Water governance in the twentieth-first century. Ambient. soc. Campinas, v. 10, n. 2.

[2] Del Rio, V., Oliveira, L. (Eds.) (1999). Percepção ambiental: a experiência brasileira. (2ª ed.). São Carlos: Studio Nobel.

[3] Figueiredo, M.C.B.; Vieira, V. P. P. B.; Mota, S.; Rosa, M. F.; Araújo, L. F. P.; Girão, Ê.;

[4] Ducan, B. L. (2008) Monitoramento comunitário da qualidade da água: uma ferramenta para a gestão participativa dos recursos hídricos no semi-árido. Revista de Gestão de Água da América Latina - REGA. Porto Alegre, v.5, n.1, p.51-60, jan./jun.

[5] Gil, Antônio Carlos. (1999). Métodos e técnica de pesquisa social. São Paulo: Atlas S.A.

[6] Lima, R. T. Percepção ambiental e participação pública na gestão dos recursos hídricos: perfil dos moradores da cidade de São Carlos, SP (Bacia Hidrográfica do Rio Monjolinho). Dissertação de Mestrado em Engenharia Ambiental. Escola de Engenharia, USP, 2003.94 p

[7] Rocha, L. B. (2003). Fenomenologia, semiótica e Geografia da Percepção: Alternativas para analisar o Espaço Geográfico. Revista da Casa da Geografia de Sobral, Sobral, v.4/7, p.67-79.

[8] Tuan, Y. F. Topofilia: um estudo da percepção, atitudes e valores do meio ambiente. São Paulo: Difel, 1980.

[9] Santos, A. C; Nunes, O. O; Figueiredo, M. L. F. A percepção da população das comunidades de Torrões sobre a qualidade da água dos poços Amazonas. Caminhos de Geografia. Uberlândia, v.9, n.28, p.243-261, dez. 2008.

[10] Solanes, M. e Jouralev, A. (2006). Water governance for development and sustainability. Serie Recursos Naturales e Infraestrutura. Santiago, Comisión Económica para América Latina y el Caribe (Cepal). 


\section{Capítulo 9}

Usos múltiplos dos recursos hídricos em propriedade rural na Bacia Hidrográfica do Rio Tarumã-Açu, Manaus - Am

Solange Batista Damasceno

Elton Alves de Souza Filho

Samara Beatriz da Silva Mendonça Alves

Resumo: 0 trabalho tem como pressuposto os múltiplos usos que o grupo familiar de uma residência no ramal do Pau-rosa, km 21 da BR 174 em Manaus-AM, faz com os recursos hídricos. A utilização da água para a balneabilidade, dessedentação humana, utilização da água em fertirrigação do pomar após tratamento em biodigestor e afazeres domésticos diversos. Além da sensililização familiar, a replicação da prática sustentável de utilização racional da água aos moradores do entorno da propriedade modelo.

Palavras Chave: Usos Múltiplos, Tarumã-Açu, Manaus, Amazonas. 


\section{INTRODUÇÃO}

As práticas sociais em um contexto marcado pela degradação permanente do meio ambiente e do seu ecossistema, envolve a necessária articulação com educação ambiental. Uma vez que as práticas sociais degradadoras são condizentes com a ausência da sensibilização ambiental, no mesmo instante que é perceptível a prática dos atores que estão engajados no universo educativo. A educação ambiental potencializa conhecimento, capacitação profissional e a comunidade, tanto acadêmica quanto a que de alguma forma convivem nesse universo beneficiam-se das mais diversas formas, seja na qualidade de vida e bem estar social, seja na qualidade ambiental.

Partindo do princípio que a maior parte da população brasileira vive em cidades, observa-se a crescente degradação das condições de vida, refletindo uma crise ambiental. Isto nos remete a uma necessária reflexão sobre os desafios para mudar as formas de pensar e agir em torno da questão ambiental numa perspectiva contemporânea. Leff (2001) fala sobre a impossibilidade de resolver os crescentes e complexos problemas ambientais e reverter suas causas sem que ocorra uma mudança radical nos sistemas de conhecimento, dos valores e dos comportamentos gerados pela dinâmica de racionalidade existente, fundada no aspecto econômico do desenvolvimento.

A prática de sustentabilidade estabelecida pela comunidade rural, refletida no cuidado com a natureza e ao bem estar dos que ali moram, se dar geralmente pelo respeito a quem abriga, oferece seus bens naturais, mas que reage e possui sua interdependência.

A forma pela qual o grupo familiar da residência localizada no ramal do Pau-rosa, km 21 da BR 174 em Manaus-AM, faz uso dos recursos hídricos é exatamente o princípio do que foi estabelecido na legislação de gestão dos recursos hídricos, uso comum à todos de forma que sejam partícipes do processo, usufruto e conservação dos mananciais de forma sustentável.

No contexto do qual a Lei $\mathrm{n}^{\circ}$ 9.433/97 descreve que as políticas de gestão de recursos hídricos devem ser implantadas sem dissociação dos aspectos de quantidade e qualidade, pois se faz necessário priorizar a qualidade da água ainda que haja abundância. A Lei $\mathrm{n}^{\circ} 9.433 / 97 \mathrm{em}$ seu capitulo $1^{\circ} \mathrm{e}$ inciso IV descreve que a gestão dos recursos hídricos deve sempre proporcionar o uso múltiplo das águas para irrigação, uso doméstico, pesca, pecuária, indústrias, entre outros usos ou seja, o manejo dos recursos hídricos deve prever uma quantidade racional e integrada entre os diversos atores que a utilizam. É necessário que haja equilíbrio entre o quanto se utiliza (quantidade), a forma que se utiliza (usos múltiplos) e o nível de qualidade para utilização por cada forma de uso (qualidade das águas).

Independentemente do quantitativo que se deva ter em disponibilidade para o uso direto ou indireto da água se faz necessário entender que este é um bem natural limitado, dotado de valor econômico e uso comum, sendo, portanto responsabilidade de todos a sua conservação no seu estado natural.

Dentro deste contexto é visto que a cidade de Manaus, capital do estado do Amazonas, apesar de possuir abundância de recursos hídricos em virtude de estar localizada na maior bacia de água doce do mundo, a bacia Amazônica e está as margens de grandes rios como Solimões, Negro e Amazonas, e ainda possuir um recurso subterrâneo estratégico, o aquífero Alter do Chão, apresenta um quadro de grande pressão sobre os recursos hídricos em sua zona urbana, pois grandes quantidades de resíduos sólidos, efluentes domésticos e efluentes industriais são lançados sob os mananciais superficiais sem tratamento prévio adequado.

0 crescimento desordenado da cidade de Manaus e a baixa efetividade das politicas de saneamento ambiental são fatores primordiais para o quadro de degradação dos corpos hídricos urbanos e periurbano da capital, o que contribuem significadamente na estatística em que coloca o Amazonas como uma das menores taxas de coleta e tratamento de esgoto do país.

A capital do estado do Amazonas possui bacias hidrográficas urbanas e periurbanas de médio a grande porte, como São Raimundo, Tarumã-Açu, Educandos, Puraquequara e muitas sub-bacias. A bacia do Tarumã-Açu, por exemplo, possui área geográfica urbana, de transição e rural, onde apresenta trechos de degradação e contaminação de suas águas. 0 trecho rural da bacia apresenta baixos impactos antrópicos, principalmente no que se trata de qualidade das águas nas sub-bacias, devido ainda possuir área de floresta bem conservada.

No presente estudo foram identificadas quatro práticas de uso dos recursos hídricos em uma propriedade particular situada no km 21 da BR 174, Ramal do Pau-Rosa, zona rural de Manaus, área de abrangência da bacia hidrográfica do Tarumã-Açu. As práticas de uso sustentável dos recursos hídricos estão voltadas 
para balneabilidade, dessedentação humana, utilização da água em fertirrigação do pomar após tratamento em biodigestor e afazeres domésticos diversos.

Foram realizadas análise dos parâmetros físico-químicos, $\mathrm{pH}$, condutividade elétrica, alcalinidade, oxigênio dissolvido, alcalinidade, turbidez e demanda bioquímica de oxigênio (DBO) visando avaliar a qualidade das águas utilizadas conforme os usos previstos na legislação CONAMA n³57/2005 e Portaria 2.914/2011, no que diz respeito a balneabilidade e potabilidade para fins de consumo humano.

\section{2.ÁREA DE ESTUDO}

A Bacia Hidrográfica do Tarumã-Açu, está localizada nas zonas Norte e Oeste do Município de Manaus, sendo um tributário da margem esquerda do Rio Negro. Possui uma especificidade singular por sua malha hídrica está toda no município de Manaus, da nascente a foz, obtendo-se o quantitativo de 133.756,40 hectares correspondendo $16 \%$ da área territorial do município de Manaus.

A área da propriedade particular ao qual o estudo se refere está situada no km 21 da BR-174, zona rural do município de Manaus, localizada no ramal do Pau-Rosa, área de abrangência da bacia do Tarumã-Açu figura 1, local onde foram identificadas as quatro práticas de uso sustentável dos recursos hídricos, balneabilidade, dessedentação humana, utilização da água em fertirrigação do pomar após tratamento em biodigestor e afazeres domésticos diversos.

Figura 1 - Mapa de identificação da área de estudo na zona rural de Manaus-AM. Em vermelho consta a estrada de acesso ao Ramal do Pau-Rosa pela estrada BR-174.

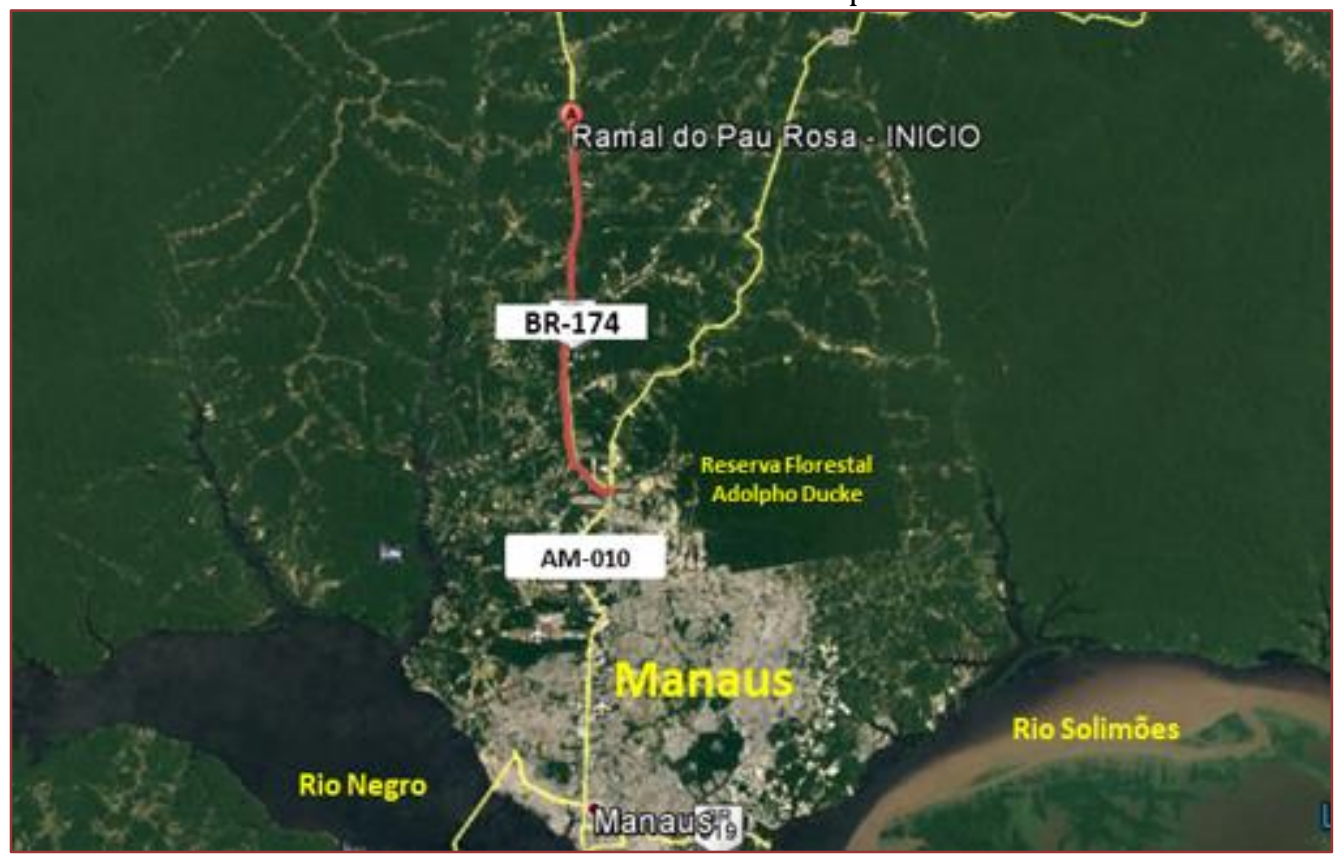

\section{MATERIAL E MÉTODOS}

0 local de estudo foi identificado em visita à casa de um morador da zona rural de Manaus-AM, denominado de A, no qual o grupo familiar utiliza a localidade apenas nos finais de semana e feriados, com frequência de aproximadamente 5 pessoas por vez.

Na moradia da propriedade, de características ecológicas onde o reaproveitamento de resíduos florestais é uma prática cultural da família, detectaram-se os múltiplos usos da água, figura 2. 
Figura 2. A - Captação de água para dessedentação humana; B - Balneabilidade em canal do igarapé. C Fertirrigação após tratamento em biodigestor.

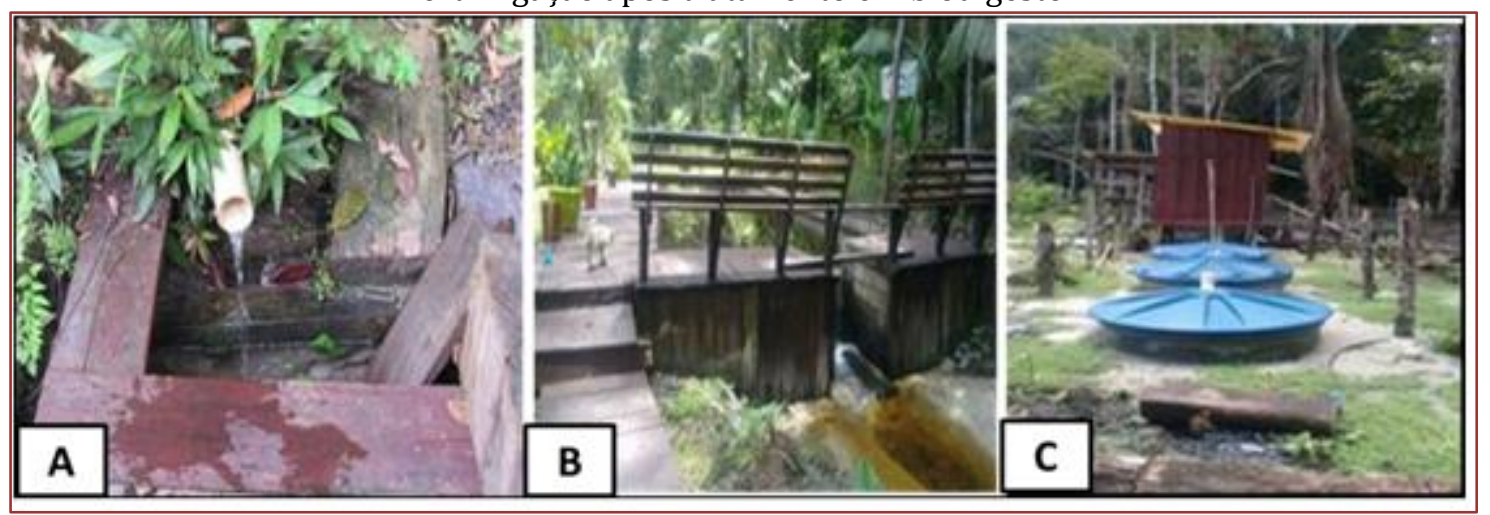

No caso A, os moradores aproveitam a percolação natural, por gravidade, da água do talude que faz limite da propriedade no qual foi inserido um cano de PVC de $50 \mathrm{~mm}$ onde ocorre o escoamento. No local é captada a água para dessedentação da família e utilização para alimentação.

No caso B, o morador utiliza o canal do igarapé para balneabilidade, neste foi construído uma espécie de piscina natural com madeira local e um barramento na extremidade para que nos finais de semana a comporta é fechada e a piscina enche, sendo portanto esvaziada durante o percurso da semana. 0 morador relata que não há nenhum tipo de tratamento da água na piscina natural.

No caso C, segundo relato do morador, com o intuito de não contaminar o igarapé com os dejetos da propriedade do qual faz uso, buscou uma tecnologia de tratamento de esgoto domiciliar para propriedade rural, no qual foi instalada com recursos financeiros próprios. 0 sistema de tratamento é composto por três caixas de mil litros cada uma, que são interligadas por tubulação. Na primeira caixa hermeticamente fechada, onde são recepcionados os dejetos é colocado a cada trinta dias $10 \mathrm{~kg}$ de esterco bovino para o início do tratamento através da metabolização da matéria orgânica por fungos e bactérias presentes no esterco. 0 esterco animal neste processo possui a finalidade de acelerar o processo de degradação da matéria orgânica do efluente gerado com liberação de gás metano e gás carbônico através de suspiro na parte superior da segunda e terceira caixa da fossa biodigestor.

A segunda caixa onde ocorre a depuração e tratamento secundário do processo, nesta possui um suspiro na horizontal por onde saem os gases. Na terceira caixa, já pode ser observada apenas o líquido com coloração escura e sem odor, de onde é retirada a água para realização da fertirrigação do pomar da propriedade no período de baixa pluviosidade local.

O quarto uso de água observado na propriedade é o captação de água do leito do igarapé próximo da moradia ecológica, ou seja, do mesmo igarapé onde é utilizado também para balneabilidade. A água é utilizada para as diversas atividades domésticas, como torneiras internas, lavagem de louças e alimentos, descarga dos banheiros e chuveiros, entre outras.

Constatou-se, portanto que em nenhum dos quatro tipos de uso da água é realizado tratamento prévio e controle de qualidade, então para aferir tais parâmetros e propor medidas de controle foi realizado análise de água em todos os pontos onde é retirada a água para usufruto com os seguintes parâmetros: $\mathrm{pH}$, condutividade elétrica, alcalinidade, oxigênio dissolvido, demanda bioquímica de oxigênio e turbidez.

\section{RESULTADOS E DISCUSSÕES}

Foi realizada análise de qualidade da água nos pontos onde o recurso hídrico é utilizado para consumo humano na propriedade apenas dos parâmetros físico-químicos para averiguação se estavam de acordo com a legislação pertinente, Resolução CONAMA n³57/2005 e Portaria n 2.914 de 2011 - Ministério da Saúde, tabela 1. 
Tabela 1 - Análise de Qualidade de Água nos pontos da propriedade.

\begin{tabular}{c|c|c|c|c|c|c|} 
Pontos & $\begin{array}{c}\mathrm{pH} \\
\text { (N/A) }\end{array}$ & $\begin{array}{c}\text { Condutividade } \\
\text { Elétrica (uS/cm) }\end{array}$ & \multicolumn{2}{c|}{$\begin{array}{c}\text { Olcalinidade (mg/L) } \\
\text { Dissolvido } \\
(\mathrm{mg} / \mathrm{L})\end{array}$} & DBO (mg/L) & $\begin{array}{c}\text { Turbidez } \\
\text { (NTU) }\end{array}$ \\
\hline P1 & 4,69 & 14,70 & 1,22 & 6,71 & 6,49 & 0,78 \\
\hline P2 & 5,35 & 7,30 & 1,83 & 8,76 & 7,72 & 4,16 \\
\hline P3 & 8,40 & - & 4,88 & 0,00 & - & 46,02 \\
\hline P4 & 5,97 & 10,59 & 4,27 & 7,05 & 4,77 & 1,56 \\
\hline
\end{tabular}

Fonte: DAMASCENO, 2017

Ao analisar os resultados obtidos, averiguamos que parâmetro como $\mathrm{pH}$ quase todos os pontos coletados, estão dentro do limite estabelecido na Portaria 2.914/2011, porém o P1 pode ser classificado na característica de límpido, de acordo com o limite estabelecido, estando portanto em estado ótimo de conservação.

Quando se avalia o parâmetro Turbidez verifica-se que o P1, P2 e P4, estão atendendo a Portaria 2.914/2011, porém o P3 não atende o que prescreve a legislação.

Na análise do Oxigênio Dissolvido para os quatro ponto se averiguou que, apenas no P3 a água está sem oxigenação em função de permanecer confinada na terceira caixa do biodigestor onde fica armazenada para a dispersão por fertirrigação. Os demais pontos P1, P2 e P4 estão dentro que prescreve o CONAMA $357 / 2005$.

No que se refere ao DBO, verifica-se que para P1 e P2 estão acima do estimado como valor máximo mediante o CONAMA 357/2005 e para P3 não foi registrado em função de não ter registro na água analisada.

Para a Alcalinidade da água nos pontos de coletas, todos os quatro pontos aparecem com águas alcalinas, com maior destaque para o P3 e P4.

No parâmetro Condutividade Elétrica o ponto P1 se destacou com maior índice e para P3 não aparece registro em função da água após tratamento das duas caixas anteriores do biodigestor não ter tido contato com outros materiais pelo fato de permanecer confinada.

As análises realizadas para averiguação se estavam de acordo com a legislação pertinente, Resolução CONAMA n³57/2005 e Portaria nº 2.914 de 2011 - Ministério da Saúde

\section{CONCLUSÕES}

A partir dos resultados obtidos nos pontos de coleta e avaliação dos usos múltiplos da água na propriedade rural da bacia do Tarumã-Açu, verifica-se que para os pontos P1 e P2 face aos parâmetros analisados em consonância com a legislação 2.914/2011 do Ministério da Saúde a água não se encontra apropriada para fins de consumo humano. Portanto não é recomendado seu consumo sem o devido tratamento, de acordo com os critérios de potabilidade. Todavia recomenda-se análise dos parâmetros bacteriológicos para a observância dos critérios de potabilidade e utilização para utilização nas atividades domésticas.

Para a avaliação dos pontos P3 e P4 pode-se enquadra-los de acordo com o CONAMA 357/2005 e CONAMA 430/2011 em classe 2. Todavia se faz necessário análise mais aprofundada para avaliar outros parâmetros não contemplados e enquadrá-los mediante a legislação e usos preponderantes na área.

Em virtude deste trabalho não ter realizado análise dos parâmetros bacteriológicos, não foi possível classificar a água do igarapé utilizada para fins de recreação, conforme CONAMA 274/2000.

No que concerne ao resultado do P3 verificou-se que houve mudança das características da água mediante os parâmetros físico-químicos. As alterações provenientes dos processos bioquímicos e químicos ocorridos na fossa biodigestora ocasionados em virtude do consumo de oxigênio pelas bactérias presentes no esterco animal em contato com a matéria orgânica gerada a partir dos dejetos domésticos, o oxigênio dissolvido foi consumido no processo e o pH passou à básico. Como a água é utilizada para fins de fertirrigação no pomar, não há problemas quanto ao uso. Mas, caso seja o descarte voltado para o igarapé, deverá utilizar outros tipos de tratamento auxiliares e formas de reoxigenação da água, uma vez que a água da caixa 3 da fossa biodigestora encontrava-se com oxigênio zero. 
Os parâmetros analisados neste trabalho foram o marco para se avaliar a importância que a investigação possui frente à qualidade da água que se têm e o destino que se dá a ela a partir dos mais diversos usos que são praticados por cada indivíduo na sociedade. Este trabalho avaliou isoladamente uma propriedade rural, ao qual se observou a prática sustentável de usufruto da água em uma propriedade particular.

A prática do grupo familiar na utilização da água pode-se inferir que é reflexo da educação ambiental recebida em algum momento através dos diversos atores educacionais, especialmente no que se refere a economia da água, a reciclagem dos materiais de forma produtiva e enriquecedora e ainda o aproveitamento do potencial da natureza a partir da gravidade e percolação natural.

E ainda a prática do grupo familiar em transferir aos moradores à montante da sua propriedade as tecnologias usadas de conservação natural do curso d'água e modos diversos de usufruto dos recursos hídricos, podemos considerar que é uma prática de gestão bacia, ou seja, uso coletivo da água. 0 que podemos considerar a partir da desta experiência é que os moradores já possuem na sua cultura local esta prática, cabendo, portanto aos órgãos intervenientes, gestor e implementador da Política de gestão da água, bem como ao Comitê de Bacia do rio Tarumã-Açu subsidiá-los com os conhecimentos técnicos voltados à gestão de bacia.

O trabalho de orientação e de sensibilização ambiental da comunidade do entorno da propriedade, objeto deste trabalho, bem como da bacia do Tarumã-Açu como um todo deve ser realizado amplamente, aproveitando o potencial que os moradores já possuem, as experiências vividas na natureza e as relações sociais que lhes são peculiares.

\section{REFERÊNCIA}

[1] Agência Nacional de Águas. Panorama da Qualidade das Águas Superficiais no Brasil. Agência Nacional de Águas, Superintendência de Planejamento de Recursos Hídricos. Brasília: Ana, SPR, p.176. 2005.

[2] Brasil. Ministério do Meio Ambiente. Lei Federal 9.433, 08.01.97, que institui a Política e o Sistema Nacional de Recursos Hídricos, in: Política Nacional de Recursos Hídricos, 2ª edição, Secretaria Nacional de Recursos Hídricos, Brasília-DF. 1997.

[3] Brasil. Ministério da Saúde. Portaria n.o 2.914, de 12 de Dezembro de 2011. Dispõe sobre normas de potabilidade de água para o consumo humano. Brasília: SVS, 2011.

[4] Brasil. Resolução Conama 357, de 17 de março de 2005. Conselho Nacional de Meio Ambiente. 2005.

[5] Brasil. Resolução Conama 430, de 13 de maio de 2011. Conselho Nacional de Meio Ambiente. 2011.

[6] Campos, Z.E.S. Parâmetros físico-químicos em igarapé de água clara e preta ao longo da rodovia BR-174 entre Manaus e Presidente Figueiredo - AM. Dissertação de Mestrado, em Biologia Tropical e Recursos Naturais, Instituto Nacional de Pesquisas da Amazônia, Manaus, Amazonas. 54 pp. 1994.

[7] Coelho, S. C.; Mucci, J. L. N. In: Pelicioni, M. C. F.; Philippi JR., A. Educação Ambiental: Desenvolvimento de Cursos e Projetos. São Paulo: Signus, 2000.

[8] Silva, M.S.R.; Ramos, J.P.; Pinto, A.G..N. Metais de Transição nos Sedimentos de Igarapés de Manaus-AM. Acta Limnologica Brasiliensis, v.11, p.89-100. 1999.

[9] Sioli, H.; Klinge, H. Solos, Tipos de Vegetação e Águas na Amazônia. Boletim geográfico. v.79, p. 23-39. 1962. 


\title{
Capítulo 10
}

\section{Análise de parâmetros microbiológicos da água da Represa Jurumirim, Avaré - SP}

\author{
Bruna Maria da Silva Hamano \\ Yara Laureano Francisco \\ Camila Ferreira Bannwart Castro \\ Mariana Morena de Vieira Santos Greatti \\ Adrielli Cristina Peres da Silva \\ Igor Otavio Minatel \\ Viviane Mattos Pascotto
}

Resumo: A água é vital para a vida dos seres humanos, fauna e flora, porém, também serve como veículo de transmissão de várias doenças causadas por micro-organismos. Existem poucas regiões no mundo que apresentam áreas livres de contaminação e poluição da água. A Represa Jurumirim que é situada na região de Avaré-SP, é um importante atrativo turístico, muito utilizado para balneabilidade e classificada como área despoluída e com ótima qualidade da água. 0 presente estudo avaliou os parâmetros microbiológicos da água da represa com o intuito de verificar os níveis de coliformes fecais e coliformes termotolerantes. Foram coletadas 18 amostras da água da represa jurumirim, em 3 pontos diferentes pré-estabelecidos e 44\% dessas amostras apresentaram contaminação por coliformes termotolerantes. A represa Jurumirim foi considerada própria para lazer e recreação, uma vez que as amostras analisadas não ultrapassaram o limite de concentração de bactérias, no entanto, há necessidade do desenvolvimento de políticas públicas preventivas direcionadas para a preservação dessas águas, no intuito de conscientizar a população quanto a importância da represa Jurumirim para a promoção saúde e prevenção de doenças, além do desenvolvimento socioeconômico regional e contínuas análises para esse monitoramento.

Palavras-chave: Análise Microbiológica de Água; Represa Jurumirim; Bactérias Termotolerantes. 


\section{INTRODUÇÃO}

A água é indispensável para os seres humanos, tanto quanto para as plantas e animais. Sendo assim, sua qualidade é de grande importância para a promoção da saúde da população. 0 acesso à mesma é de forma segura e essencial para que haja a sobrevivência e o desenvolvimento socioeconômico da sociedade (RIOS, 2009). Os processos de deterioração da qualidade tiveram início desde que as pessoas começaram a se reunir nas cidades. Contudo, os impactos do homem no meio aquático e na qualidade da água foram bastante localizados e limitados até o início da revolução industrial (BOGARDI et al., 2012).

Mais da metade da população mundial vive, atualmente, em áreas urbanas e este número deverá aumentar no futuro. Em virtude da rápida urbanização, há uma demanda crescente por recursos hídricos em cidades que estão se expandindo e pela preservação destes recursos (UNWWAP, 2010). Nas últimas décadas, com o crescimento cada vez mais acelerado da economia, o problema tornou-se tão grande e complexo que a gestão da qualidade da água deve ser considerada como um problema moderno que requer novas abordagens. Os principais fatores que afetam a qualidade da água de rios e lagos são decorrentes de características das áreas as quais os leitos de água estão expostos. Fatores como esgoto doméstico tratado de forma inadequada e controle inadequado dos efluentes industriais estão diretamente associados às características econômicas e de administração pública de cada região. Entretanto, inúmeros fatores são decorrentes do avanço da agropecuária (desmatamento, agricultura migratória sem controle e práticas agrícolas deficientes) e do planejamento urbano ineficiente (destruição das bacias de captação e localização errônea de unidades industriais) (REDMAN; JONES, 2010).

Poucas regiões no mundo ainda estão livres de problemas como a perda de potenciais fontes de água doce, redução da qualidade da água e poluição das fontes de superfície e subterrâneas. Desta forma, é comum atualmente os ecossistemas aquáticos serem perturbados, e as fontes vivas de água doce ameaçadas. Os mananciais urbanos são úteis para abastecer a população e satisfazer suas necessidades, sendo o uso mais nobre da água, destinado ao consumo doméstico, porém o manancial deve possuir quantidade e qualidade adequadas para satisfazer os diversos usos (AMARAL et al., 2003; TUCCI, 2006).

A água serve de veículo para a transmissão de uma variedade de doenças causadas por micro-organismos. A microbiologia sanitária trata de controle desse problema enfocando particularmente nas enfermidades decorrentes da contaminação fecal e estas doenças são resultantes da ingestão de água e alimentos contaminados ou de água poluída utilizada para irrigação, pesca e recreação (ROITMAM;TRAVASSOS; AZEVEDO,1987 apud LOPES SOBRINHO et al., 2015).

A Organização Mundial de Saúde (OMS) divide as doenças de veiculação hídrica em dois grupos: doenças de transmissão hídrica e doenças de origem hídrica. As primeiras são caracterizadas pela presença de micro-organismos patogênicos veiculados pela água, tais como: vírus, fungos, protozoários e bactérias, acometendo geralmente o trato gastrintestinal. Já as doenças de origem hídrica são caracterizadas pela presença de substâncias químicas na água, acima das concentrações permitidas (CETESB, 1997 apud FERNADES et al., 2017).

0 melhor método de assegurar água adequada para consumo consiste em formas de proteção, evitando-se a contaminação das fontes hídricas com dejetos animais e humanos, os quais podem conter grande variedade de bactérias, vírus, protozoários e helmintos (DAHI,1992). Entre os micro-organismos patogênicos detectados comumente em água contaminada estão as bactérias pertencentes aos gêneros Shigella sp, Salmonella typhi, Salmonella parathyphi A e B, Campylobacter, Escherichia coli enterotóxica, Yersinia enterocolítica; agentes virais como o vírus da hepatite A, e protozoários como Crystosporidium sp., Giardia lambia e Entamoeba histolytica (TUNDISI; TUNDISI, 2005).

No que se refere ao uso para lazer e recreação de contato primário, ou seja, em águas destinadas à balneabilidade, a principal variável considerada é a microbiológica. Assim, a concentração de coliformes totais e de termotolerantes são usados como indicadores de contaminação e risco à saúde dos banhistas (DIAS; ROMERO, 2014). Coliformes totais são bacilos gram-negativos, aeróbios ou anaeróbios facultativos, não formadores de esporos, oxidase-negativos, capazes de desenvolver na presença de sais biliares ou agentes tensoativos que fermentam a lactose com produção de ácido, gás e aldeído a $35,0 \pm 0,5^{\circ} \mathrm{C}$ em 24 48 horas, e que podem apresentar atividade da enzima $\beta$ - galactosidase. A maioria das bactérias deste grupo pertence aos gêneros Escherichia, Citrobacter, Klebsiella e Enterobacter, embora vários outros gêneros e espécies pertençam ao grupo. Os coliformes termotolerantes são um subgrupo das bactérias do grupo coliforme que fermentam a lactose, tendo como principal representante a Escherichia coli, de origem exclusivamente fecal e considerado o mais específico indicador de contaminação fecal (FUNASA, 2013). 
A represa Jurumirim é alimentada pelo rio Paranapanema, tem 100 quilômetros de comprimento e 3 quilômetros de largura em alguns pontos, sendo o principal atrativo turístico da região sudoeste do estado de São Paulo. Ao seu redor existem loteamentos com aproximadamente 650 casas dentre as quais residem populações fixas e segundas residências. É importante destacar o fato de que, inicialmente, a água da represa de Jurumirim somente era utilizada para a geração de energia elétrica, sendo, portanto, considerado unicamente como um recurso energético. Contudo, com a formação do lago do reservatório, este local também passou a ser utilizado para atividades de recreação e turismo no município de Avaré (CAROLINO, 2006).

Considerando os problemas de saúde associados a fontes de água contaminada, o objetivo do presente estudo foi verificar os parâmetros microbiológicos e consequente qualidade da água da Represa Jurumirim, situada na região Sudoeste do estado de São Paulo.

\section{METODOLOGIA}

\subsection{COLETA DE AMOSTRAS}

As amostras foram coletadas na Represa Jurumirim, situada na região Sudoeste do estado de São Paulo. 0 município escolhido para a realização da coleta das amostras de água é a Estância turística de Avaré, que apresenta intensa atividade turística. Dezenas de empreendimentos estão localizados às margens da represa, como hotéis e loteamentos de segunda residência.

Ao todo foram coletadas 18 amostras da água da represa Jurumirim, em 3 pontos diferentes préestabelecidos (Figura 1).

Figura 1: Imagem de Satélite, mostrando a Represa Jurumirim e marcadores indicando os pontos de coleta

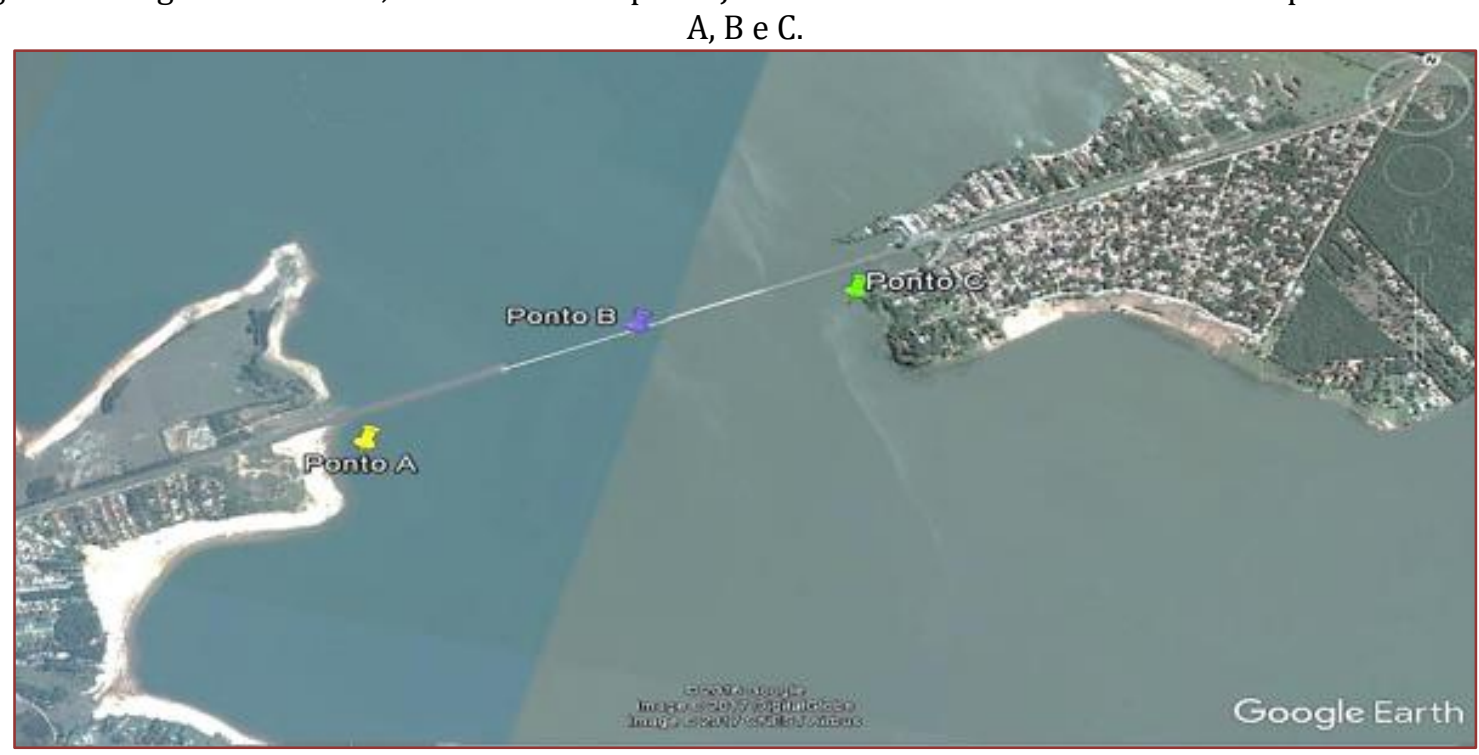

Fonte: Google Earth

Os pontos de coleta foram definidos com o intuito de obter amostras representativas dos locais mais utilizados pelos banhistas (ponto A, conhecido como "Prainha"), de uma região central da represa (ponto $\mathrm{B}$, área central da ponte que interliga os pontos $\mathrm{A}$ e C) e de uma área destinada para camping (ponto C).

Para o cálculo de amostragem, uma das metodologias aplicadas é baseada na replicação dos procedimentos de amostragem ou partes deles (réplica de amostras), sendo esse o método mais adequado para fins ambientais, pois considera que os analitos investigados podem variar em função do tempo e do espaço (EURACHEM, 2007). De acordo com a Agência Nacional de Vigilância Sanitária, (ANVISA), em análises que representam uma região pequena, uma duplicata de cada amostra já é considerada representativa para análise e classificação da qualidade da água para lazer e recreação. Então, para realizar uma análise sólida e verídica, foram coletadas duas amostras de cada ponto do local (A, B e C) em dias diferentes: 30 de abril, 02 e 08 de maio de 2017, obedecendo as previsões do Instituto Nacional de 
Meteorologia e o movimento de pessoas, pois estes poderiam interferir na quantidade de microorganismos e na qualidade da água.

As amostras foram coletadas em frascos esterilizados (30 $\mathrm{ml}$ cada), mergulhados a uma profundidade de aproximadamente $20 \mathrm{~cm}$. Nos pontos A e C, a água foi coletada adentrando-se no rio e afastando-se da margem, pelo menos, três metros. No ponto B, as coletas foram feitas sobre a ponte. Para facilitar a coleta desse ponto, foi confeccionado um artefato que permitisse a imersão dos frascos de coleta. Utilizou-se uma sacola em trama de rede, que continha os dois frascos estéreis, o qual foi atrelado à rede com um barbante, próximo à extremidade do fundo. Na outra extremidade do mesmo frasco (gargalo), amarrou-se, também com barbante, um objeto com massa superior a do frasco de vidro, possibilitando assim que o frasco afundasse e coletasse águas mais profundas e não superficiais. Os barbantes possuíam comprimento suficiente para que, quando lançados de cima da ponte, pudessem tocar e afundar na água (Figura 2A).

Sobre a ponte foi suspenso o frasco amarrado por dois barbantes, juntamente com a rede e o peso. Durante a descida até a água, o frasco destampado ficou suspenso pelo barbante que foi amarrado na extremidade do fundo, ficando assim com a abertura virada para baixo, onde se encontrava a pedra. Soltou-se o barbante até que o frasco mergulhasse no rio. Somente após o frasco afundar com o auxílio da pedra, é que o outro barbante atrelado próximo ao gargalo e à pedra foi então puxado, fazendo com que o frasco virasse sua abertura para cima e ocorresse então seu enchimento pela água. Após isso, era suspenso pelo barbante que se prendeu na parte superior do frasco, até alcançar a ponte novamente (Figura 2B).

Figura 2: Procedimentos para coleta de amostras no ponto B (sobre a ponte). A: Sacola de Trama de Rede; B: Descida dos tubos de cima da ponte.

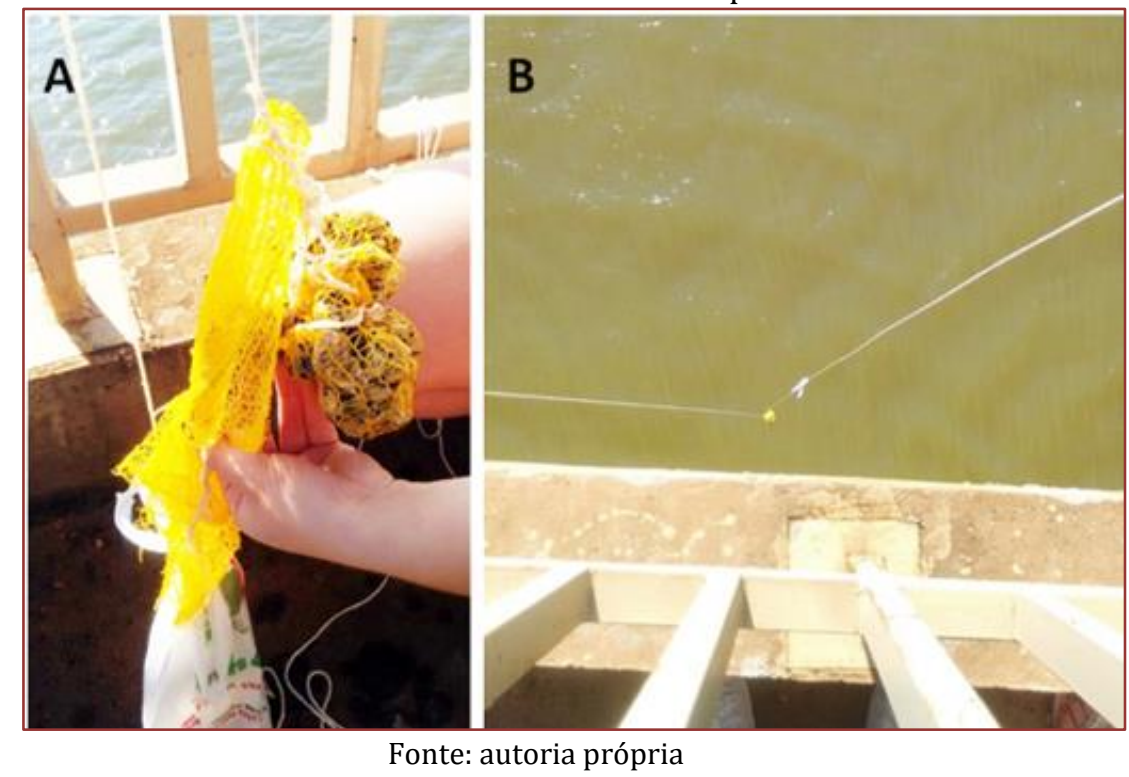

A primeira coleta foi realizada entre as 18:00h e as 18:40h do dia 30/04. A segunda no período da tarde entre $14: 25 \mathrm{~h}$ e $15: 45 \mathrm{~h}$ no dia $02 / 05$, já a terceira coleta ocorreu no período da manhã entre $9: 27 \mathrm{~h}$ e 10:49h no dia 08/05. Segundo as previsões durante os dias de coleta, a média máxima de temperatura em Avaré-SP foi de $27^{\circ} \mathrm{C}$ e a média mínima de $14^{\circ} \mathrm{C}$.

Logo após a coleta, as amostras foram devidamente identificadas com local, horário da coleta e assim transportadas em recipiente isotérmico com gelo até o Laboratório de Microbiologia do Centro Universitário Sudoeste Paulista (UniFSP), localizado em Avaré, SP.

\subsection{ANÁLISES LABORATORIAIS}

As amostras foram transferidas para tubos Falcon estéreis (10 mL cada) e centrifugadas. Do volume total de $10 \mathrm{~mL}$, descartou-se $7 \mathrm{~mL}$ e as amostras concentradas foram utilizadas para análise microbiológica. Após centrifugação, $10 \mu \mathrm{L}$ do concentrado foi adicionado a tubos contendo $10 \mathrm{~mL}$ de caldo Triptona de Soja com Lauril e Lactose, além de tubo de Durham invertido para visualizar a produção de gás. Estes tubos foram incubados a $37^{\circ} \mathrm{C}$ e $45^{\circ} \mathrm{C}$ por $48 \mathrm{~h}$, para verificar a presença de coliformes fecais e termotolerantes. A acidificação, com ou sem produção de gás, à partir da fermentação da lactose no meio 
de cultura empregado no experimento, é prova presuntiva positiva para a presença de bactérias do grupo coliforme. No fim das 48 horas os tubos que não apresentaram gás e turbidez foram considerados negativos e os que apresentaram, foram considerados positivos.

Para teste confirmativo, as amostras positivas, foram então semeadas em placas contendo ágar Verdebrilhante, a $37^{\circ} \mathrm{C}$ por $48 \mathrm{~h}$. As colônias isoladas foram submetidas a identificação através da confecção de lâminas coradas pelo método de Gram e semeadas em tubos contendo meio de Rugai.

\section{RESULTADOS E DISCUSSÃO}

\subsection{PORCENTAGEM DE CONTAMINAÇÃO POR COLIFORMES TERMOTOLERANTES}

Os resultados do presente trabalho demonstraram que 44,44\% das amostras coletadas apresentaram contaminação por coliformes termotolerantes (Figura 3) e em 37,5\% dessas amostras, foi possível à identificação da espécie Escherichia coli.

Figura 3: Porcentagem de coliformes termotolerantes encontrados em água coletada da Represa Jurumirim ( $\mathrm{n}=18$ amostras).

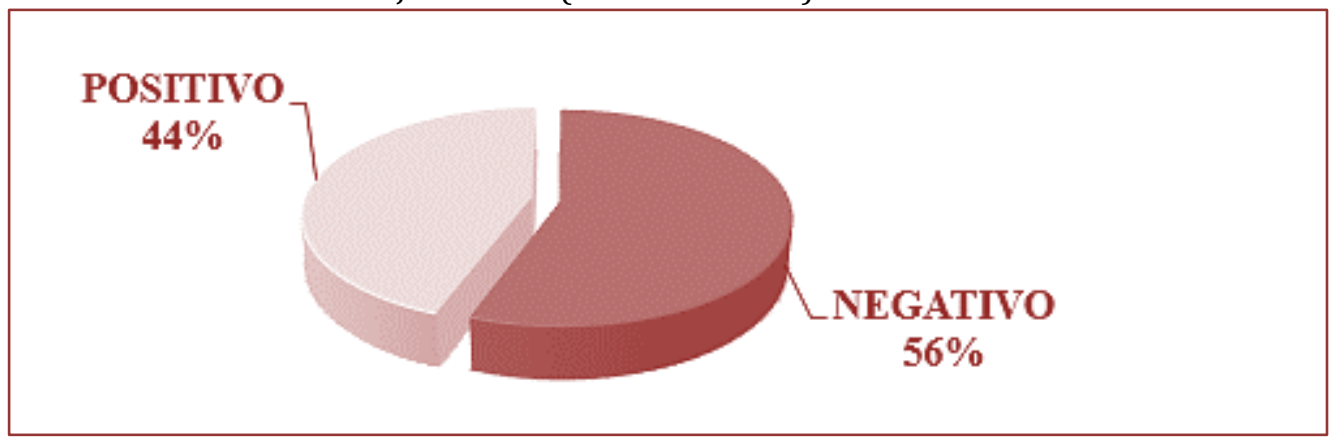

\subsection{COLIFORMES TERMOTOLERANTES EM CADA PONTO DE AMOSTRAGEM}

O ambiente é a base dos recursos naturais e sua proteção é primordial para o sucesso do turismo a longo prazo. A capacidade da localidade em absorver a quantidade de visitantes é elemento-chave do planejamento do turismo sustentável (OLIVEIRA, 2005).

A figura 4 demonstra que, das amostras coletadas em cada ponto em dias diferentes $(n=6)$, houve contaminação por coliformes termotolerantes em 4 delas no ponto A; 5 amostras no ponto B e 3 amostras do ponto C, apontando, então, a importância de realizar os testes laboratoriais para esse local.

Figura 4: Quantidade de amostras positivas e negativas para coliformes termotolerantes encontrados em água coletada da Represa Jurumirim em cada ponto da coleta ( $\mathrm{n}=6$ amostras/ ponto).

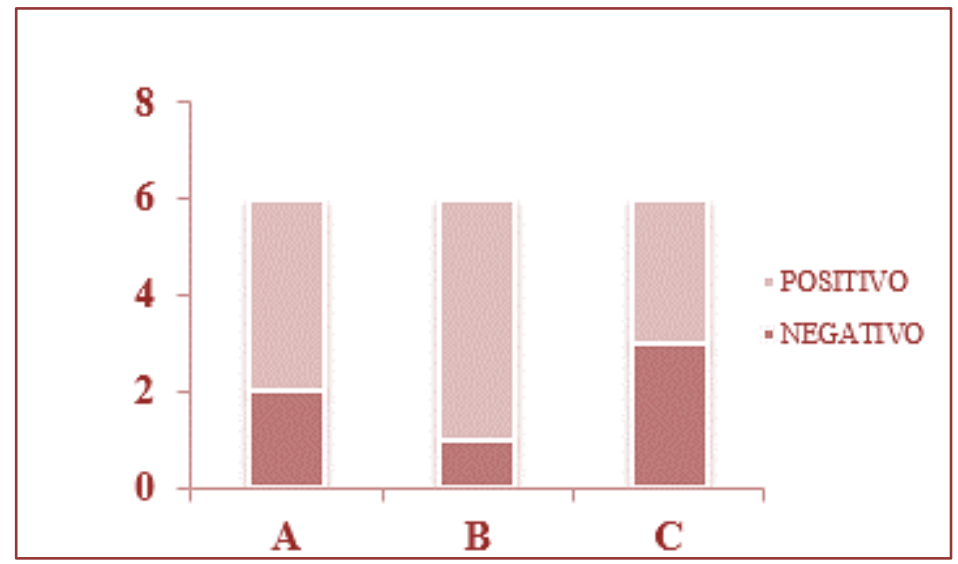




\subsection{TIPOS DE COLIFORMES TERMOTOLERANTES IDENTIFICADOS}

O ponto A apresentou contaminação por Enterobacter sacarose positiva em duas amostras. No ponto B, foi encontrada a bactéria Escherichia coli sacarose positiva em 33,33\% das amostras. E no ponto C constatouse a presença de Shigella sp, e E. coli sacarose positiva em amostras de dias diferentes (Figura 5).

Figura 5: Identificação dos coliformes termotolerantes encontrados em água coletada da Represa Jurumirim em diferentes pontos.

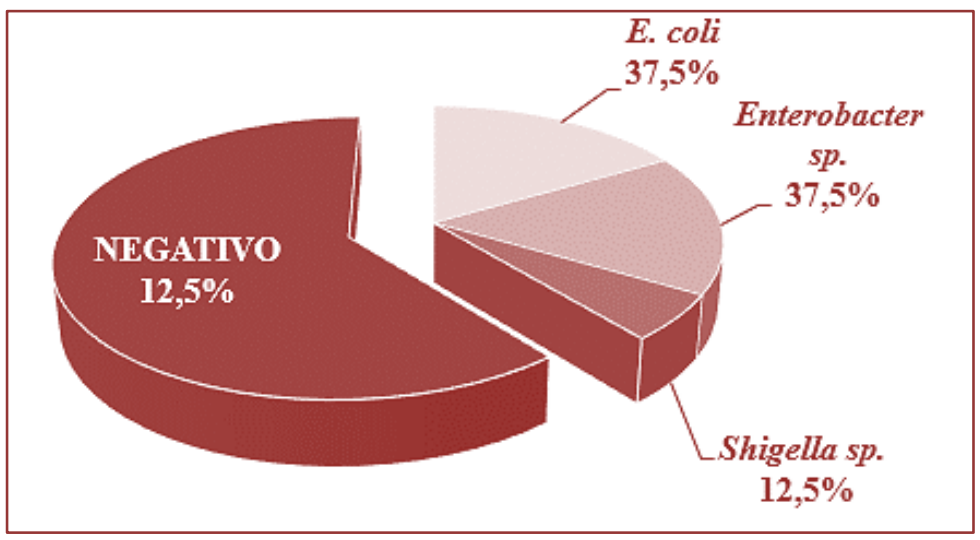

A Resolução CONAMA nº 274/2000 que define os critérios para a balneabilidade em águas brasileiras, considera que a saúde e o bem-estar humano podem ser afetados pelas condições de balneabilidade e, desta forma, estabelece padrões de qualidade ambiental. 0 órgão classifica as águas doces, salobras e salinas destinadas à recreação nas categorias própria e imprópria. Sendo as consideradas próprias, subdivididas quanto a qualidade em: excelente, muito boa e satisfatória. Esta classificação ocorre de acordo com a quantidade de coliformes termotolerantes ou E.coli ou enterococos encontrados em $80 \%$ de um conjunto de amostras obtidas.

Portanto, diante dos resultados obtidos das análises e levando em consideração a resolução citada acima e outros trabalhos semelhantes, podemos classificar a água da Represa Jurumirim como própria para balneabilidade e de qualidade muito boa, por apresentar positividade para coliformes termotolerantes em menos de 50\% de suas amostras. Esses dados reiteram a importância de realizar análise de água de locais cujo frequência da população é alta, uma vez que as doenças de veiculação hídrica são causadas principalmente por micro-organismos patogênicos de origem entérica, animal ou humana, transmitidas basicamente pela rota fecal-oral, ou seja, são excretados nas fezes de indivíduos infectados e ingeridos na forma de água ou alimento contaminado por água poluída com fezes (GRABOW, 1996).

Segundo dados da OMS, 80\% das doenças que ocorrem nos países em desenvolvimento são ocasionadas pela contaminação da água. Estima-se que, aproximadamente, doze milhões de pessoas morrem, anualmente, em todo o mundo, por problemas relacionados à qualidade da água. No Brasil, os registros do Sistema Único de Saúde (SUS) mostram que 80\% das internações hospitalares do país são devidas às doenças de veiculação hídrica (WHO, 2010). Trabalhos mostram que o rio Itanhém, rio que percorre as proximidades de Teixeira de Freitas, apresentaram contaminação por coliformes termotolerantes, pois vem sofrendo impacto em suas águas em decorrência da entrada de efluentes, oriundos do município, que não recebem tratamento (CUNHA et al., 2012).

Durante a última década, problemas de escassez e de poluição da água têm exigido dos governos e da sociedade em geral uma maior atenção para o assunto (MEJIA et al., 2012).

A Represa Jurumirim, por ser um atrativo turístico, pode-se supor que a deterioração de um recurso importante como a água ocorre principalmente em razão da falta de consciência ambiental dos turistas e da população local; da falta de um sistema de saneamento básico; do consumo elevado de energia dos hotéis, da deficiência ou inexistência de uma gestão ambiental. Deste modo, se estes problemas não forem solucionados, a atividade turística poderá trazer sérios prejuízos do ponto de vista social e ambiental (CAROLINO, 2006). 


\section{CONCLUSÃO}

A represa Jurumirim foi considerada própria para lazer e recreação, uma vez que as amostras analisadas não ultrapassaram o limite de concentração de bactérias, no entanto, as análises laboratoriais indicam que a represa vem sofrendo um pequeno impacto negativo em suas águas devido a presença de bactérias do grupo coliformes termotolerantes encontrada em algumas amostras. Portanto, há necessidade do desenvolvimento de políticas públicas preventivas direcionadas para a preservação dessas águas, no intuito de conscientizar a população quanto a importância da represa Jurumirim para a promoção saúde e prevenção de doenças, além do desenvolvimento socioeconômico regional e contínuas análises para esse monitoramento.

\section{REFERÊNCIAS}

[1] Amaral, l.. A., et al. Água de consumo humano como fator de risco à saúde em propriedades rurais. Rev. Saúde Pública, v.37, n.4, pp.510-514, 2003.

[2] Bogardi J. J., et al. Water security for a planet under pressure: interconnected challenges of a changing world call for sustainable solutions. Current Opinion in Environmental Sustainability. v. 4, n. 1, p. 35-43, 2012.

[3] Brasil. Conselho Nacional do Meio Ambiente (Conama). Resolução N.274, de 29 de Novembro de 2000. p.7071. Disponível em: http://www.mma.gov.br/port/conama/legiabre.cfm?codlegi=272. Acesso: 02/05/2017.

[4] Brasil. Ministério da Saúde - Agência Nacional de Vigilância Sanitária (Anvisa). Portaria N.518, de 25 de Março de 2004. Disponível em: http://bvsms.saude.gov.br/bvs/publicacoes/portaria_518_2004.pdf. Acesso em: 24/06/2017.

[5] Carolino, E. F. Alterações dos recursos energéticos decorrentes das atividades turísticas no Município de Avaré-SP. (Tese de doutorado) - Universidade Estadual Paulista, Faculdade de Ciências Agronômicas, 2006. Disponível em: http://hdl.handle.net/11449/101765

[6] Cetesb (Companhia Estadual de Tecnologia e Saneamento Ambiental). Controle da qualidade da água para consumo humano: bases conceituais e operacionais. São Paulo: CETESB, 1997.

[7] Cunha, A. H. et al. Análise microbiológica da água do rio Itanhém em Teixeira de Freitas BA. Revista Biociências. v.16, n. 2, 2010.

[8] Dahi, E. Water Supply in Developing Countries: Problems and Solutions. Lyngby: Eds. Technical, University of Denmark. 1992.

[9] D’aguila, P. S., et al. Avaliação da qualidade de água para abastecimento público do Município de Nova Iguaçu. Cad. Saúde Pública. v..16, n..3 Rio de Janeiro. 2000.

[10] Dias, G. M.; Romero, D. C. G. Atividades de lazer e recreação em praias fluviais no município de Rosana (SP). In: Anais do Congresso Nacional de Meio Ambiente de Poços de Caldas, Poços de Caldas-MG, 2014, p. 1-6.

[11] Eurachem/ Citac Eurolab, Nordtest and the RSC Analytical Methods Committee. Measurement uncertainty arising from sampling: A guide to methods and approaches. Ed 1, 2007.

[12] Fernandes. A. C. G. et al. Análises Descritivas e Microbiológicas das Águas Minerais Envasadas e Comercializadas na Região Metropolitana de Recife-PE. Ciência e Natureza, v. 39, n.02, p.272-284, 2017.

[13] Funasa - Fundação Nacional de Saúde. Manual prático de análise de água. 4⿳ạa ed. - Brasília: Funasa, 2013. 150 p.

[14] Grabow, W.O.K Waterborne diseases: Update on water quality assessment and control. Water AS. v. 22, p. 193-202, 1996.

[15] Lopes Sobrinho, O. P. et al. Análise microbiológica das águas do Rio Itapecuru no perímetro urbano do município de Codó, no Maranhão. Revista Ibero-Americana de Ciências Ambientais, Aquidabã, v.6, n.1, 2015.

[16] Mejía, A. et al. Agua potable y saneamento en América Latina y el Caribe: metas realistas y soluciones sostenibles. Caracas: Development Bank of Latin America (CAF- Banco de Dessarollo de America Latina), 2012. Disponível em: <publicaciones.caf.com/media/17238/libro_agua_esp.pdf>.

[17] Oliveira, A. Turismo e desenvolvimento: planejamento e organização. São Paulo: Atlas, 2005.

[18] Redman, C. L.; Jones, N. S. The environmental, social, and health dimensions of urban expansion. Popul. Environ. v. 26, p. 505-520, 2005.

[19] Rios, L.C.A. Avaliação do nível de contaminação do rio Itapecuru na zona urbana de Caxias, MA. Monografia (Graduação), Cesc/Uema. Caxias-MA, 2009. 
[20] Roitmam, I.R.;Travassos,L.R.;Azevedo,J.L. Tratamento de Microbiologia Ed. Manole Ltda. São Paulo, 1987 p. 85.

[21] Tucci, C. E. M. Água no meio urbano. In: REBOUÇAS, A. C.; BRAGA, B.; TUNDISI, J. G. Águas Doces no Brasil: Capital Ecológico, Uso e Conservação. 3. ed. São Paulo: Escrituras, 2006. cap. 12, p. 399-432.

[22] Tundisi, J.G. Tundisi, T.M.A.; Água. São Paulo. Publifolha. 2005.120p.

[23] Unwwap - United Nations World Water Assessment Programme. Water for Sustainable Urban Human Settlements Briefing Note; United Nations Human Settlements Programme (Un-Habitat): Perugia, Italy, 2010.

[24] World Health Organizadion.- Water Global Annual Assessment of Sanitaion and Drinking - Water. GLAAS 2010. Targeting Resources for Better Results; 2010. 


\section{Capítulo 11}

\section{Degradação ambiental do Rio Araçuaí do ponto de vista da memória local}

\section{Andréia Galvão Soares \\ Edilson Luiz Cândido}

Resumo - Neste artigo é evidenciada a degradação ambiental sofrida pelo rio Araçuaí, na área urbana do Município de Araçuaí. Onde se coletou através de entrevistas com ribeirinhos urbanos, dados referentes ao conhecimento temporal em relação a questões ambientais referentes o trecho urbano do o rio Araçuaí. Também foi realizada analise a degradação ambiental do rio Araçuaí de modo visual in loco. Nota-se que os moradores ribeirinhos situados no Bairro Alto Santuário guardam lembranças de uma época onde o rio Araçuaí representava lazer e alternativas econômicas. Com tudo, infelizmente é perceptível a tristeza nos relatos que indicam a atual situação do rio, que não é mais segura para as atividades de lazer e laborais, como refrescar em suas águas e ou lavagem de vestes. Visualmente, o impacto relatado pelos moradores entrevistados é evidenciado por deposito de resíduos sólidos, animais domésticos, ausência de vegetação ciliar e rede de esgoto a céu aberto. Águas de tonalidade verde escura evidencia a proliferação de algas, alimentadas por dejetos orgânicos.

Palavras-chave: Percepção Ambiental. Recursos Hídricos. Poluição Ambiental. Ribeirinhos. 


\section{INTRODUÇÃO}

O município de Araçuaí está localizado no Nordeste de Minas Gerais, no Médio Jequitinhonha, a uma distância de 678 km de Belo Horizonte. De acordo com informações disponíveis na página eletrônica da PMA (Prefeitura Municipal de Araçuaí, 2015), sua emancipação política ocorreu no dia 21 de Setembro de 1871, por força da Lei no 1870 . Possui uma área de $2.326 \mathrm{~km}^{2}$, tendo também cerca de 70 Comunidades Rurais.

A história deste município nos aponta importantes conexões com o rio Araçuaí, principal afluente da margem direita do rio Jequitinhonha, de acordo com (Diniz et al 2015). Seu próprio nome tem origem nessa relação. Conforme a PMA (2015), Calhau era o nome do arraial que nos anos de 1830 começou a formar-se na planície entre a chapada do Piauí e a do Candonga, onde o instável Calhauzinho faz barra no caudaloso rio Araçuaí, ficando o arraial na margem direita de ambos. Chama-se calhau o cascalho de pedras lisas e arredondadas pela correnteza da água dos córregos. Com este cascalho estão ainda calçadas algumas ruelas da zona velha da cidade que bem possível àquele "luxo" deve seu primeiro nome. Mas seja como for, ainda hoje usam o nome "Calhau", embora que já em 1857, quando o mesmo lugar foi criado vila, tivesse mudado seu nome para Arassuahy, que com a moda da ortografia virou Arassuaí, e ultimamente Araçuaí.

Segundo Diniz et al (2015), o rio Araçuaí, possui extensão de $250 \mathrm{~km}$ e área total de $16.343 \mathrm{~km}^{2}$. De acordo Ernani (2015), o rio Araçuaí é um rio grande que passa por 19 municípios e abastece 23, sendo cerca de 500 mil pessoas no Vale do Jequitinhonha que de maneira ou de outra precisam do rio Araçuaí para sobreviver. É responsável pela prática das principais atividades econômicas da região, como a agropecuária e a pesca, inclusive o rio é utilizado para o abastecimento de toda população da cidade.

Por outro lado, atualmente, como destaca Hernani (2015), vemos muito esgoto sendo jogado diretamente no rio, e nas suas margens, sem nenhum tratamento, afetando as espécies de peixes existentes e ocasionando um mal cheiro muito forte. Há também um vasto desmatamento de suas matas ciliares ao seu entorno. Além disso, salienta o autor, nos últimos 60 anos a linda praia que existia abaixo da ponte do rio Araçuaí foi substituída por um rio sem praias, totalmente degradado e com esgoto sendo jogado constantemente nele e também no córrego calhauzinho que deságua no mesmo. Desse modo, a degradação assola todo o rio.

Segundo Braga et al (2008), a água é fundamental à vida humana e à manutenção da biodiversidade terrestre e aquática, ela impulsiona os ciclos biogeoquímicos e o funcionamento dos ecossistemas. A água tem, também, um papel econômico de grande relevância, uma vez que seus usos múltiplos- produção de alimentos, abastecimento publico, geração de hidroeletricidade, navegação e desenvolvimento industrial fomentam as economias locais, regionais e nacionais.

Nesse sentindo a má utilização da água do rio Araçuaí contribui para sua série de problemas, afetando toda população que se abastece do mesmo. Assim, o presente trabalho se propõe a investigar as possíveis alterações ao longo dos anos referentes ao rio Araçuaí por meio da percepção dos moradores da memória local.

\section{MATERIAL E MÉTODOS}

\section{1 ÁREA DE ESTUDO}

A pesquisa foi realizada no rio Araçuaí em área urbana do município de Araçuaí MG, conforme a figura 1. Onde se coletou através de entrevistas com questionário semiestruturado, dados referentes ao conhecimento temporal em relação a questões ambientais referentes o trecho urbano do rio Araçuaí. Foram 22 (vinte e duas) entrevistas no total, coletadas entre junho a agosto de 2015. O bairro escolhido foi o Alto Santuário, justificando sua proximidade as margens do rio. A imagem a seguir, ilustra o local da pesquisa. 


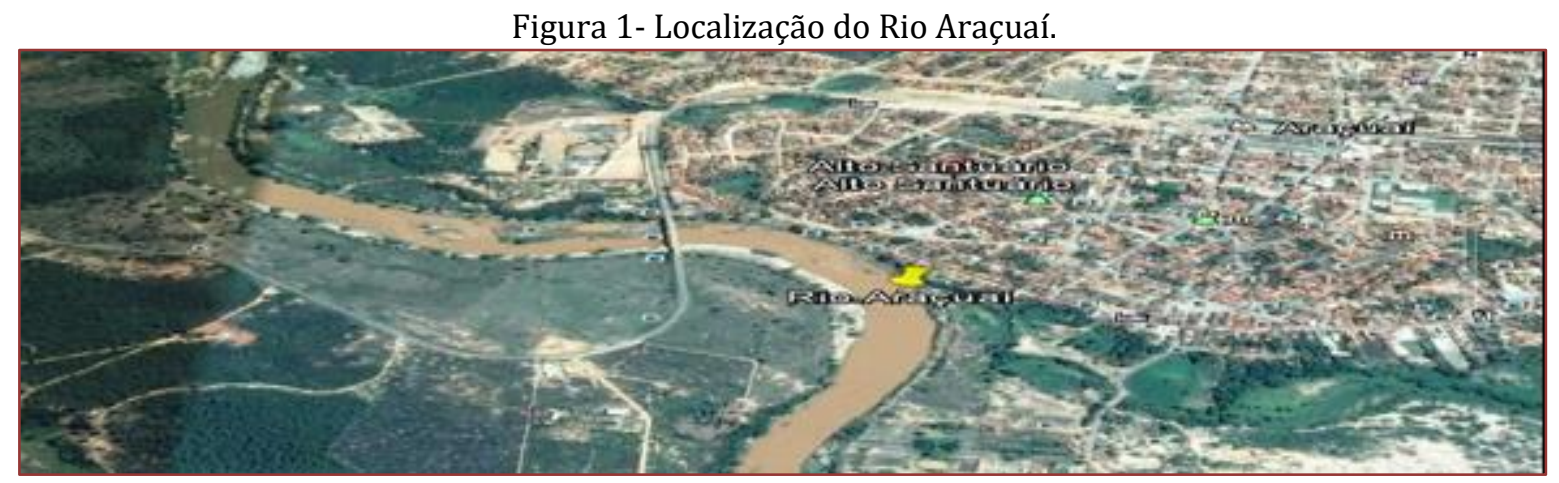

Fonte: adaptado de Google Earth, 2015.

\section{OBTENÇÃO E ANÁLISE DE DADOS}

Visto que o intuito da presente pesquisa foi levantar pontos de vistas de moradores (Percepção) em relação à degradação do rio Araçuaí, observamos que dentro das Ciências Sociais, a "Pesquisa Qualitativa" pode ser fracionada num em "Estudo de caso" no qual, segundo Neves (1996), tal tipo de pesquisa não busca enumerar ou medir eventos e geralmente não emprega instrumental estático para análise dos dados, enfatizando que o objetivo é amplo e tem uma perspectiva diferenciada da "Pesquisa Quantitativa".

0 modo que os entrevistados foram selecionados no presente estudo se deu através do Snowball ("Bola de Neve"), onde se escolhe os entrevistados citam outros com o conhecimento sobre o assunto a ser pesquisado.

Através de uma visita preliminar no bairro Alto Santuário, perguntamos os moradores qual a moradora que mora no bairro há mais tempo, e nos foi indicado Dona Zefa que através dela foi nos indicando outras pessoas.

Segundo Wha (1994), citado por Baldin e Munhoz (2011), o sistema "Bola de Neve" trata-se de uma pesquisa com amostra não probabilística utilizada em pesquisas sociais onde os participantes iniciais de um estudo indicam novos participantes que por sua vez indicam novos participantes e assim sucessivamente, até que seja alcançado o objetivo proposto (o "ponto de saturação"). O "ponto de saturação" é atingido quando os novos entrevistados passam a repetir os conteúdos já obtidos em entrevistas anteriores, sem acrescentar novas informações relevantes à pesquisa.

Para discutir os dados, optou-se por abordagens descritivas com tabelas e gráficos. Onde se codificou dados de interesse ao tema da pesquisa com discussão generalizada.

\section{RESULTADOS E DISCUSSÃO}

Através da "bola de neve", onde moradores mais antigos do bairro direcionavam as próximas entrevistas a outros moradores, observou-se que $50 \%$ dos moradores tinham mais de setenta anos e o restante dos entrevistados apresentaram idades entre 30 a 60 anos. Salienta-se que $100 \%$ dos entrevistados eram do sexo feminino, situação que pode ser explicada pelo horário de coleta de dados, matutino, onde os homens deveriam estar em seus afazeres profissionais. A tabela 1 a seguir demonstra a idade dos entrevistados.

Tabela 1- Idade dos entrevistados.

\begin{tabular}{|c|c|}
\hline Idade & $\mathrm{N}^{\circ}$ de entrevistados \\
\hline 30 a 40 anos & 03 \\
\hline 50 a 60 anos & 08 \\
\hline 70 a 80 anos & 11 \\
\hline
\end{tabular}

A tabela 2 demonstra o tempo de residências dos entrevistados no bairro Alto Santuário. É visto que o tempo de moradia naquele bairro, margens ao rio Araçuaí, varia de 20 a 70 anos. Tempo que demonstra certa confiabilidade nos dados coletados no que tange o acompanhamento histórico de degradação do rio Araçuaí na área urbana do município. 
Tabela 2 - Tempo de residência.

\begin{tabular}{|c|c|}
\hline Tempo de residência & $\mathrm{N}^{\circ}$ \\
\hline 20 a 30 anos & 10 \\
\hline 40 a 50 anos & 09 \\
\hline 60 a 70 anos & 03 \\
\hline
\end{tabular}

A tabela 3 a seguir apresenta os dados obtidos em relação ao questionamento sobre o uso do rio no passado. Podemos observar que foram citados $23,91 \%$ usava o rio para tomar banho, 9,78\% usava para fazer piquenique e $8,69 \%$ praticava a pesca. Viu-se que a população também lavava suas roupas, onde foi citada tal pratica por $22,82 \%$ dos entrevistados. Entres outras utilizações citadas em menor proporção. A Figura 2 representa a utilização de tomar banho no rio anos atrás.

Tabela 3- Dados sobre o uso do rio Araçuaí há 20 anos.

\begin{tabular}{|c|c|c|}
\multicolumn{1}{c|}{ Citações } & \multicolumn{2}{c|}{$\mathrm{N}^{\circ}$} \\
\hline Lavar roupas & 21 & $22,82 \%$ \\
\hline Lavar vasilhas & 13 & $13,04 \%$ \\
\hline Água p/ consumo & 19 & $20,65 \%$ \\
\hline Tomar banho & 22 & $23,91 \%$ \\
\hline Pesca & 8 & $8,69 \%$ \\
\hline Piquenique & 9 & $9,78 \%$ \\
\hline
\end{tabular}

Figura 2 - Ponte sobre o rio Araçuaí.

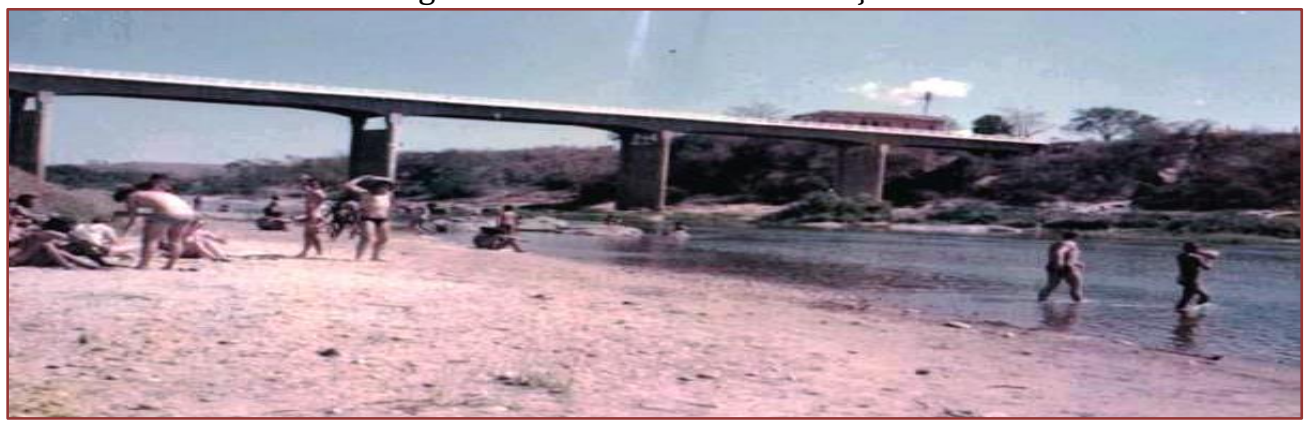

Fonte: HERNANI, 2015.

No gráfico 1 abaixo, demonstra as citações sobre o uso atual do rio Araçuaí. Os entrevistados fizeram 32 citações, onde $68,75 \%$ (22) das citações apontaram que o rio Araçuaí está poluído, impossibilitando de praticar qualquer atividade de lazer. Entretanto, ainda houve citações sobre a utilização no abastecimento de água na cidade, $21,25 \%(22)$.

Gráfico 1 - Quais são os principais usos do rio Araçuaí hoje?

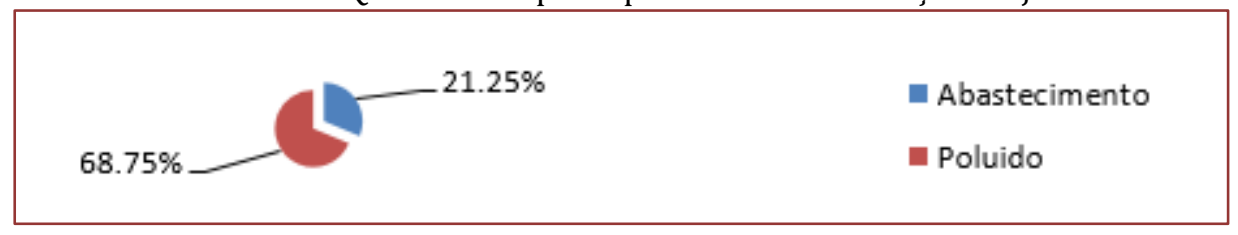

Em consulta a COPASA no dia 24/09/2015 nos foi informado que o abastecimento de água do município de Araçuaí é proveniente do próprio rio Araçuaí, onde o tratamento de água passa por vários processos de despoluição e o mesmo processo é feito com o esgoto antes de ser lançado ao rio - conforme afirmou o funcionário responsável pelo setor de tratamento de água.

Uma "senhora" lavadeira, 79 anos, moradora do bairro Santuário lavava roupa e tomava banho desde os seus sete anos de idade. Hoje ela não frequenta ir ao rio mais. "O rio hoje está com pouca água e muito poluída." - lamenta. "Hoje não dá pra tomar banho e nem lavar roupa por causa da sujeira"- lamenta. 
No gráfico 2 abaixo, demonstra as citações sobre a diferença do rio Araçuaí á vinte anos atrás e hoje. Houve 32 citações, onde 62,5 \% (22) das citações apontaram que o rio Araçuaí está muito poluído, devido o lançamento de esgotos e resíduos sólidos de toda espécie despejados ali diariamente. Contudo houve $37,5 \%$ (12) citações onde apontaram que o rio Araçuaí no passado era caudaloso possuía uma água limpa, nas suas margens havia praia e mata ciliares as pessoas frequentava o rio com grande frequência comparado hoje que não frequentam mais.

Gráfico 2- Quais as principais diferenças entre o rio Araçuaí á 20 anos e hoje?

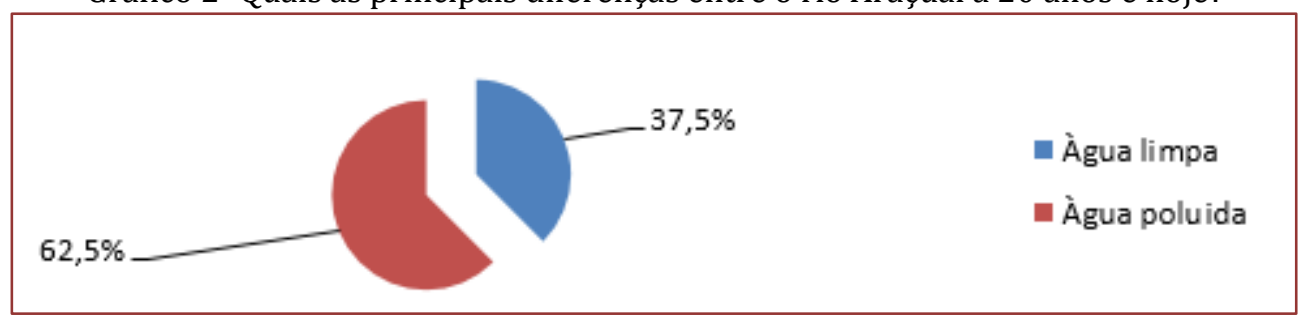

Quando foi questionado sobre o que contribuiu para essa mudança do rio Araçuaí hoje, observou-se que das 22 citações 63,63\% dos entrevistados reconhece a situação da poluição do rio Araçuaí, citando como causas lançamento de esgotos dos matadouros e dos curtumes e de resíduos sólidos. Entretanto, os outros $36,36 \%$, além de apontar essas mesmas causas, se indignam com essa condição do rio e a apresentam como um problema que mereça prioridade de atenção do poder público.

Vasconcelos (1997), convergindo com essas citações, já afirmava que quem anda pelas margens do rio Araçuaí poderia observar facilmente a poluição provocada pelos esgotos e resíduos sólidos lançados diariamente. Assim, observa-se que o problema é antigo e vem agravando com o crescimento desordenado das cidades por ele banhadas, principalmente Araçuaí. Aliado aos esgotos e resíduos sólidos, a extração de areia, animais mortos e o sangue jorrado pelo esgoto do matadouro municipal, ajudam a compor um grave quadro de degradação de uma das mais belas paisagens e riqueza natural do município.

\section{IMPACTO AMBIENTAL NO RIO ARAÇUAÍ EM UMA ANALISE PRELIMINAR E VISUAL}

Devido às pressões da ocupação humana e dos diferentes usos do solo e do recurso hídrico formaram a paisagem, em grande parte, inúmeras áreas degradadas e fragmentadas.

Em uma visita pré-agendada no dia 28-10-2015 observou-se que a área de estudo apresenta impactos ambientais. Conforme figura 3 é visto uma supressão principalmente das encostas que apresentam vestígios de mata ciliar associado a um processo de degradação, ao longo do trecho urbano do rio Araçuaí.

A importância e utilidade das matas ciliares são inquestionáveis ao meio ambiente, nela é encontrada uma grande diversidade de animais e plantas.

Segundo Paz e Farias (2008) as matas ciliares exercem importante papel na proteção dos cursos d'água contra o assoreamento e a contaminação com defensivos agrícolas, além de, em muitos casos se constituírem nos únicos remanescentes florestais das propriedades rurais sendo, portanto, essenciais para a conservação também da fauna. 
Figura 3 - Ausencia de mata ciliar as margens do rio Araçuaí.

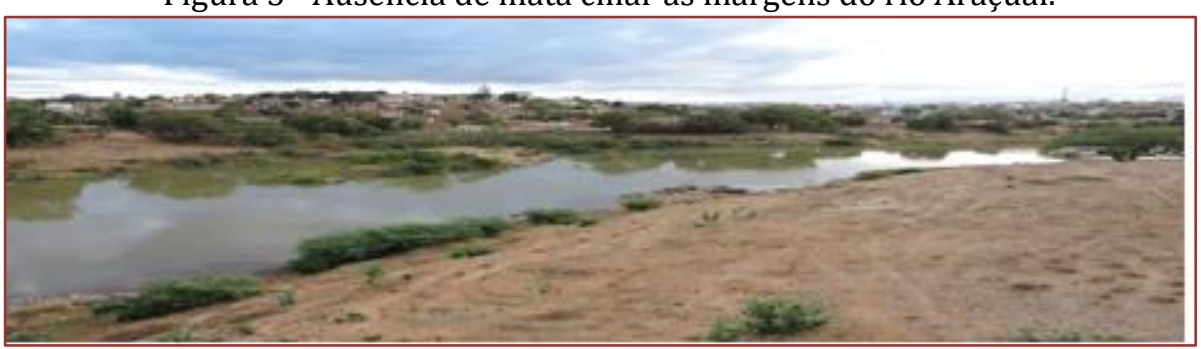

Fonte própria, 2015

Os rios sempre foram à fonte de desenvolvimento de alguns povos, uma vez que, vários deles se instalaram as margens de rios para beneficiar-se de suas águas. 0 rio Araçuai, tem residências próximas as suas margens, uma vez que esses moradores utilizam as suas águas para algumas atividades domésticas, conforme na figura 4. Por consequência foram encontrados grande quantidade de residuos sólidos em todo percurso das margens do rio Araçuaí como pode ser visto também na figura 5.

Figuras 4 e 5 - Morador lavando tripa de porco nas águas do rio Araçuaí e descarte de resíduos sólidos as margens do rio Araçuaí.

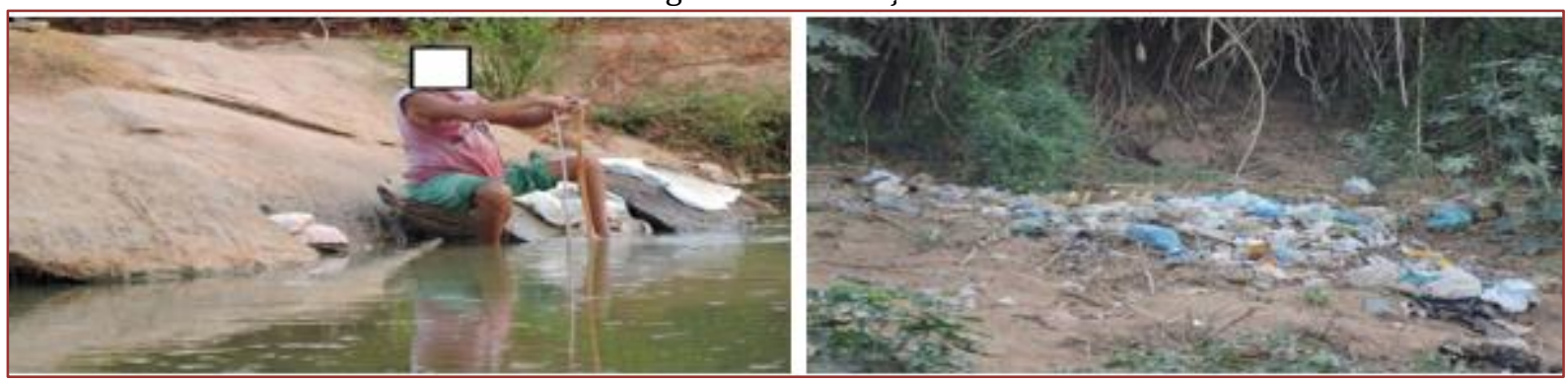

Fonte: própria, 2015.

Na figura 6, é demonstrado o lançamento de esgoto doméstico no rio Araçuaí advindas das residências localizadas as suas margens, causando efeitos negativos para a saúde ambiental e prejudicando a manutenção das condições básicas de qualidade d'água para seus diversos usos.

Observou-se presença de animais no percurso do rio Araçuaí estes que trasmitem doenças para a população ribeirinha e contamina água. Além disso desgata o solo porque o gado anda pisoteando o solo o compactando e dificultando assim a regeneração de espécies vegetais que protegem o solo.

Figura 6 - Lançamento de esgoto doméstico nas águas do rio Araçuaí.

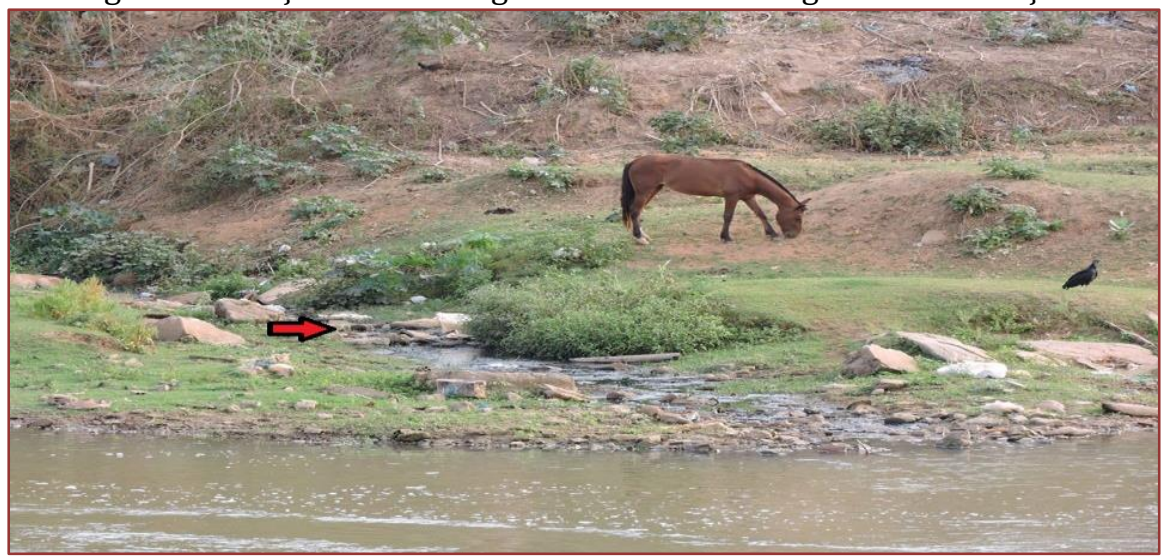

Fonte: própria, 2015. 


\section{CONCLUSÕES}

O município de Araçuaí MG tem sua história incrustada ao rio Araçuaí que leva seu nome, algo que não é levado em conta em relação à preservação do leito do Rio.

Nota-se que os moradores ribeirinhos situados no Bairro Alto Santuário guardam lembranças de uma época onde o rio Araçuaí representava lazer e alternativas econômicas. Com tudo, infelizmente é perceptível a tristeza nos relatos que indicam a atual situação do rio, que não é mais segura para as atividades de lazer e laborais, como refrescar em suas águas e ou lavagem de vestes.

Visualmente, o impacto relatado pelos moradores entrevistados é evidenciado por deposito de resíduos sólidos, animais domésticos, ausência de vegetação ciliar e rede de esgoto a céu aberto. Águas de tonalidade verde escura evidencia a proliferação de algas, alimentadas por dejetos orgânicos.

De forma conclusiva, pode se destacar a necessidade de atividades ambientais no local. Onde a Educação Ambiental com a população Ribeirinha poderá ajudar a preservação no futuro.

0 passado do rio Araçuaí não pode ser esquecido, pois é a memória do município que também está em jogo. Algo que o poder público não pode negligenciar, em seu dever na proteção deste patrimônio natural da cidade, que é o rio Araçuaí.

\section{REFERÊNCIAS}

[1] Baldim, N; Munhoz, E. M. B. Snowball (Bola de Neve): Uma técnica metodológica para pesquisa em Educação Ambiental comunitária. Anais X Congresso Nacional de Educação - Educere- I Seminário Internacional de Representações sociais, subjetividade - SIRSSE. Pontífica Universidade Católica do Paraná - Curitiba, 7 a 10 de novembro - 2011.

[2] Braga, B. P. F. et al. Pacto federativo e gestão das águas. Dossiê Água - Estudos Avançados, São Paulo, v. 22, n. 63, p. $17-42,2008$.

[3] Braga, B. P. F. et al. O desafio do desenvolvimento sustentável. São Paulo, 2. ed., p. 73-123, 2005.

[4] Brasil. Ministério de Minas e Energia. Projeto de fontes de abastecimento por água subterrâneo do Vale de Jequitinhonha. Disponível em: <http://www.cprm.gov.br/rehi/atlas/jequitinhonha/relatorios/003.pdf>. Acesso em: 05 mai. 2015.

[5] Brasil. Lei no 12.305/10 Política Nacional dos Resíduos Sólidos. Disponível em: <http://www.mma.gov.br/Politica-de-residuos-sólidos>. Acesso: 09 nov. 2015.

[6] Carvalho, R. A.; Oliveira, M. C. V. Princípios básicos de saneamento do meio. São Paulo. 3. ed. Editora SENAC. São Paulo, 2003.

[7] Conama - Conselho Nacional do Meio Ambiente. Resolução CONAMA 01, de 23 de janeiro de 1986. Dispõe sobre procedimentos relativos a Estudo de Impacto Ambiental. Disponível em: <http://www.mma.gov.br/port/conama/res/res86/res0186.html>. Acesso em: 05 mai. 2015.

[8] Derisio, J. C. Introdução ao Controle de Poluição Ambiental. 3. ed., São Paulo: Signus Editora, 2007.

[9] Diniz, H. N.; Pereira, P. R. B.; Pereira, S. Y.; Gutjahr, M. R.;Torrigo, M. 1998. Utilização de curvas de depleção de rios para estimativa de parâmetros hidrodinâmicos de aqüíferos freáticos: exemplo da bacia do rio Capivari, CentroSul do Estado de São Paulo.

[10] Ernani J. de M. M. Esgoto e lixo estão acabando de matar o rio Araçuaí. Disponível em: <http://kiaunoticias.com/2015/01/esgoto-e-lixo-estao-acabando-de-matar-o-rio-aracuai>. Acesso em: 24 abr. 2015.

[11] Farias, M. S.; Lima, V. L. A. Recurso Hídricos. In: ROCHA et al. Manejo Ecológico Integrado de bacias hidrográficas no semiárido brasileiro. Campina Grande: Epgraf, 2011.332 p.

[12] Fernandes, R. T. et al. Degradação Ambiental e Indicadores Socioecômicos do Município de Vitória do Mearim, Maranhão. Disponível em: <http://www.lemos.pro.br/admin/artcientifico/124027599249ed1c1852df2.pdf>. Acesso em: 09 abr. 2015.

[13] Google Earht. Disponível em: <https://www.google.com.br/intl/pt-BR/earth/>. Acesso em: 28 out. 2015.

[14] Machado, C. J. S. Gestão das águas doces. Editora inter ciência. 2004. Rio de Janeiro. 372 p.

[15] Neves, J. L. Pesquisa Qualitativa - Caractéristicas, Usos e Possibilidades. Cadernos de pesquisa em Administração, São Paulo, v. 1, n. 3, 2 sem., 1996.

[16] Paz, R. J; Farias, T. (Organizadores). Gestão de áreas protegidas: processos e casos particulares. João Pessoa: Universitária/UFPB, 2008. 
[17] Prefeitura Municipal de Araçuaí. a cidade: história. Disponível em: <http://aracuai.mg.gov.br/site/cidade/economia>. Acesso em: 18 abr. 2015.

[18] Santana, D. P. Manejo Integrado de bacias Hidrográficas. Documentos EMBRAPA. Sete Lagoas, MG, 2003. Disponível em: <http://www.cnpms.embrapa.br/publicacoes/publica/2003/documento/Doc_30.pdf>. Acesso em: 05 mai. 2105.

[19] Vasconcelos, S. Fantasma da poluição Ronda o Rio Araçuaí. Gaveta de Araçuaí. 11-1997. Disponível na Biblioteca de Araçuaí. 


\section{Capítulo 12}

Distribuição espacial de doenças relacionadas as condições sanitárias nos bairros Leader e missão em Jacobina Bahia

\section{Renato Alves Ferreira de Jesus}

Philipe Souza da Silva

José da Silva Junior

Natafia Deize Nascimento Passos

Débora Rosa Miranda

Marcus Vinicius Silva Santos

Resumo: 0 presente estudo teve como objetivo identificar e espacializar os pontos considerados fatores de risco para a proliferação das doenças dengue e calazar transmitidos por dípteros, nos bairros Leader e Missão, em Jacobina-BA, além de avaliar os principais fatores que também podem contribuir para a incidência de doenças nos dois bairros. Para obtenção das informações foram utilizados questionários em entrevistas e registo de coordenadas através de aparelho GPS. As foram lançadas no software Google Earth, possibilitando a espacialização e posterior interpretação dos resultados Os resultados obtidos possibilitaram observar que os pontos identificados possuem elementos semelhantes, principalmente por se tratar de esgoto a céu aberto, residências abandonadas, terrenos baldios. A espacialização dos dados mostrou-se ser uma ferramenta importante para uma visão sistemática da problemática na área de estudo. Dessa maneira, sugere-se medidas políticas mais enérgicas no que compete ao saneamento básico e ao controle de terrenos baldios, contribuindo assim para a redução da incidência de doenças transmitidas por dípteros.

Palavras-chave: Saneamento básico. Proliferação de vetores. Espacialização. Jacobina. 


\section{INTRODUÇÃO}

O saneamento básico, segundo a Organização Mundial de Saúde (OMS), é o gerenciamento ou controle dos fatores físicos que podem exercer efeitos nocivos ao homem, prejudicando seu bem-estar físico, mental e social. Seguindo esta vertente, a Lei Ordinária N. 11.445 estabelece as diretrizes básicas nacionais para o saneamento, citando: "conjunto de serviços, infraestruturas e instalações operacionais de: abastecimento de água potável, esgotamento sanitário, limpeza urbana, manejo de resíduos sólidos e, drenagem e manejo das águas pluviais" (BRASIL, 2007). Esta Lei ainda define o saneamento básico como um serviço que deve ser de acesso universal. Assim sendo, para alcançar este objetivo, faz-se necessário o planejamento de metas para curto, médio e longo prazo.

Apesar da importância do saneamento básico, dados mostram que somente 55\% dos municípios brasileiros estão conectados à rede geral de coleta de esgoto, sendo que apenas um terço deles realiza o tratamento adequado, enquanto os demais liberam os efluentes diretamente em corpos hídricos próximos (IBGE, 2010).

A falta de saneamento é causa direta de muitas doenças e mortes em todo o mundo. Os países mais pobres são os mais atingidos pela falta de serviços básicos, como água tratada, esgoto encanado e destinação correta do lixo, o que acaba interferindo na qualidade e expectativa de vida da população e no seu respectivo desenvolvimento. Números apontam que todos os anos, em torno de 3,5 milhões de pessoas morrem por falta de acesso à água potável e a condições mínimas de saneamento (IBGE, 2010).

0 município de Jacobina-BA apresenta alguns bairros que sofrem da precariedade de esgotamento sanitário, além de terrenos e moradias abandonadas, como observado nos bairros Leader e Missão (Figura 1). Desta forma, o objetivo deste trabalho foi avaliar as condições sanitárias nestes dois bairros, espacializando os pontos considerados fatores de riscos para disseminação de doenças transmitidas por dípteros, relacionando à questões sociais.

Figura 1. Localização dos bairros Leader e Missão em Jacobina, Bahia.

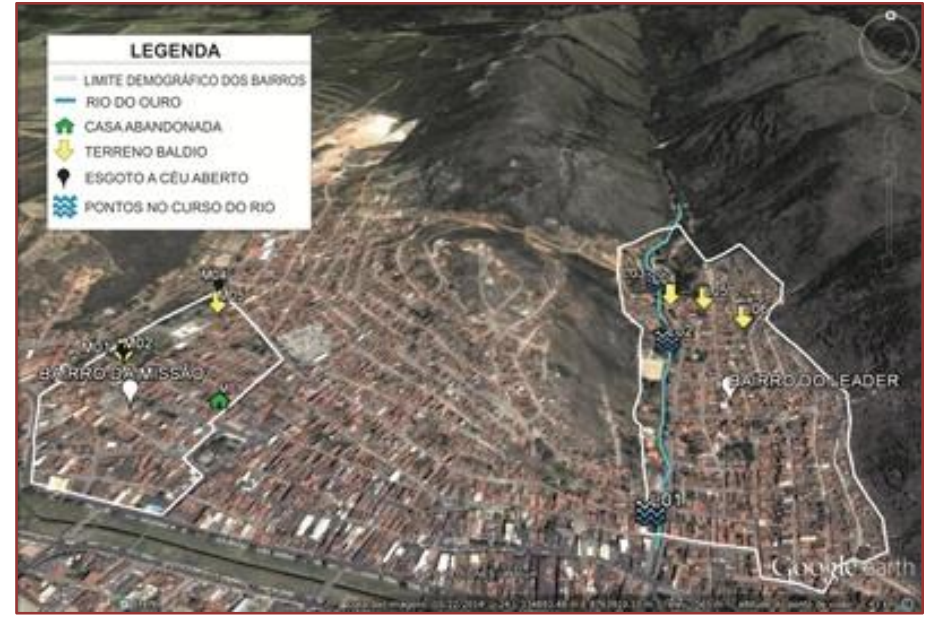

\section{MATERIAL E MÉTODOS}

A pesquisa foi realizada nos meses de outubro e novembro de 2014. Inicialmente foram levantados dados junto à Secretaria Municipal de Saúde do município de Jacobina-BA, por meio de relatórios registrados no SINAN (Sistema de Informação de Agravos de Notificação) das principais doenças que afetam as populações nas UBS (Unidade básica de saúde) dos bairros Missão e Leader, para análise preliminar de casos de doenças transmitidas por dípteros, sendo consideradas neste estudo as doenças dengue e calazar. Foram realizadas visitas nas áreas de estudo, onde observou-se as condições sanitárias, tais como acúmulo de entulho, esgoto e drenagem de rede pluvial desprotegida, ruas vulneráveis a formação de poças d'água, e construções ou terrenos abandonados. Os pontos considerados de riscos foram georreferenciados através equipamento GPS, modelo GPSMAP 78 da Garmim. Os dados coletados em campo, quando lançados no software Google Earth, possibilita a espacialização e posterior interpretação dos resultados de um SIG (FACINCANI, 2011; FREITAS et al., 2013). Para obtenção de dados preliminares que permitissem a visualização da ocorrência de doenças e os fatores sociais mais intimamente relacionados, foram aplicados 
questionários a um morador de cada uma das de 50 (cinquenta) residências visitadas em cada bairro, selecionadas aleatoriamente. 0 entrevistado, quando em concordância para participação, deveria preencher o Termo de Consentimento Livre e Esclarecido, garantindo-lhe o anonimato e a possibilidade de desistência em qualquer etapa da pesquisa.

A aplicação de questionários teve como finalidade conhecer o contexto social, econômico e higiênico sanitário da população local, à fim de possibilitar uma análise comparativa entre questões sociais com os demais fatores contribuintes para a incidência das doenças. Para tal, foram avaliados os seguintes dados: conhecimento acerca das doenças dengue e calazar, fatores socioeconômicos, e medidas de prevenção adotadas pelos participantes e pelo órgão de saúde competente.

\section{RESULTADOS E DISCUSSÃO}

No bairro do Leader foram espacializados 6 (seis) pontos, identificados como fatores de riscos para a proliferação de vetores de doenças, conforme Figura 2. Esse número apresenta relevância, levando em consideração que tais pontos apresentam características físicas propensas à incidência de doenças. 0 bairro é recortado pelo o rio do Ouro, que recebe efluentes líquidos, resíduos orgânicos, resíduos sólidos e outros elementos que contribuem para a redução do seu fluxo, e posterior aparecimento de insetos transmissores de doenças, que se utilizam da água estagnada para reprodução. Para Mendonça (2006), os rios, ao longo da historia têm servido de receptores para lançamentos de esgotos urbanos, lixos e de efluentes agroindustriais sem o devido tratamento. Neste bairro foram identificados ainda, terrenos baldios e ambientes com presença de resíduos sólidos potencialmente prejudiciais a saúde humana, de modo que, constituem uma fonte de alimento, água e abrigo para inúmeros vetores veiculadores de agentes etiológicos em hospedeiros susceptíveis (PROSAB, 2006).

Figura 2. Pontos de risco para proliferação de vetores de doenças no bairro Leader.

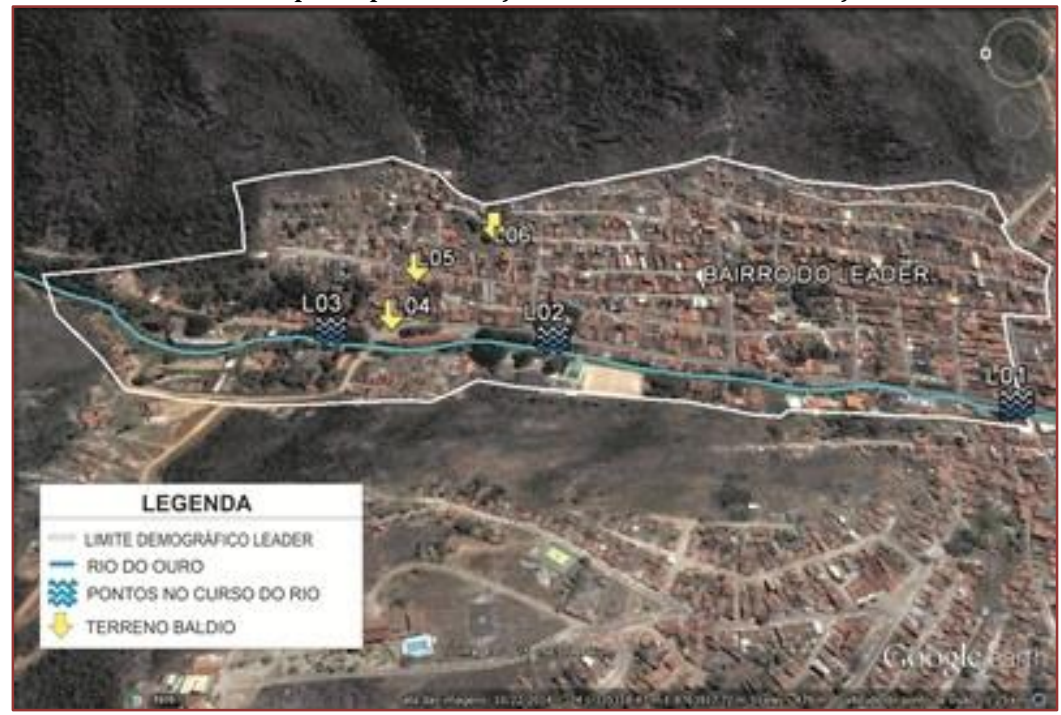

No bairro da Missão identificou-se 5 (cinco) pontos de risco no que tange à problemática do presente trabalho, conforme Figura 3. Neste contexto, os pontos exibem similaridade com os relatados no bairro do Leader, pois, sugerem condições propícias para a proliferação das doenças, sobretudo, por se tratar de residências abandonadas, terrenos baldios, e esgoto a céu aberto. 
Figura 3. Pontos de risco para proliferação de vetores de doenças no bairro Missão.

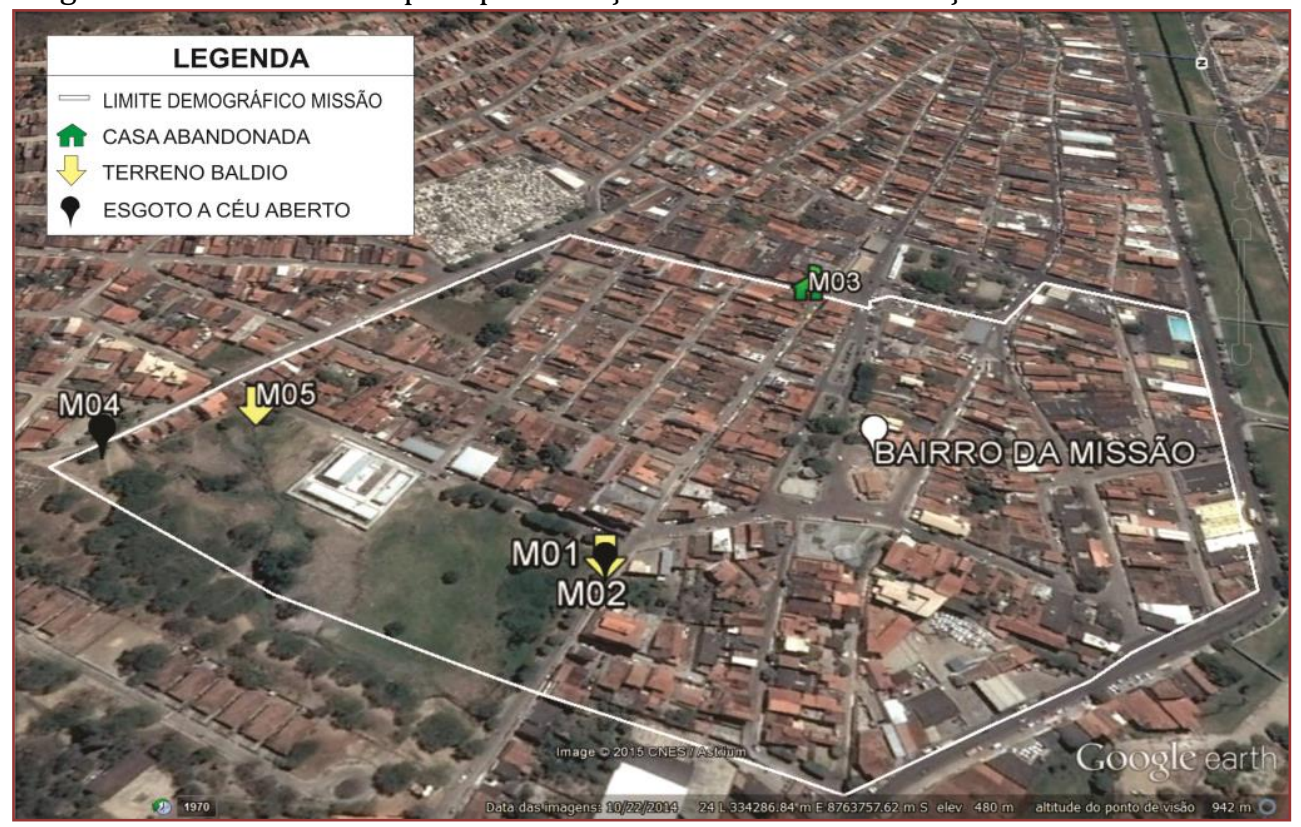

As condições observadas são propicias para a transmissão de doenças relacionadas aos dípteros, principalmente a dengue e o calazar. Segundo Tauil (2006), estas duas doenças estão entre as mais importantes que os controles de doença devem se ater. Entretanto, nem todos os programas utilizam medidas de controle vetorial, mas apenas levantamento de números de casos de dengue e calazar.

Em relação a aplicação dos questionários, foi verificado inicialmente se alguém da residência pesquisada já havia contraído dengue ou calazar. Os resultados são apresentados na Figura 4:

Figura 4. Resultado da pergunta "você ou alguém em sua residência já adquiriu as doenças dengue ou calazar?".

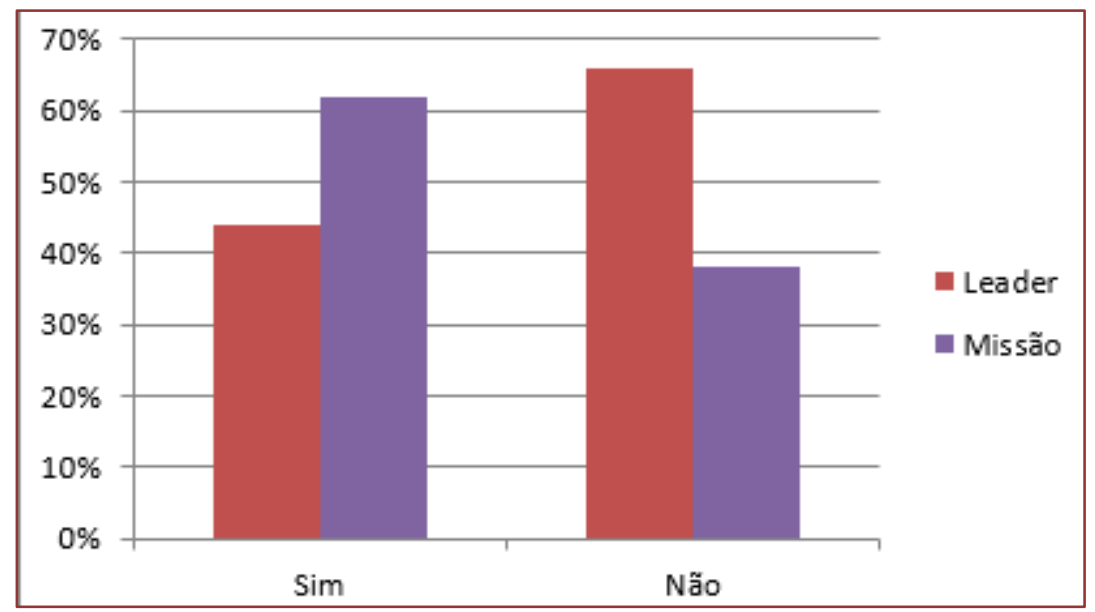

No bairro Leader, 44\% dos participantes afirmaram que algum morador de sua residência já adquiriu uma das doenças na residência, enquanto que $66 \%$ declararam que nunca foi adquirida nenhuma das doenças supracitadas. No bairro da Missão, 62\% afirmaram já terem adquirido as doenças, enquanto 38\% responderam que não. Com relação ao sexo dos moradores que já tiveram uma dessas doenças, no bairro Leader $41 \%$ pertenciam ao sexo masculino e $66 \%$ ao sexo feminino, enquanto que no bairro Missão $35.5 \%$ eram do sexo masculino e $64.5 \%$ do sexo feminino. Aqui neste estudo, prevaleceu a doença em pessoas do sexo feminino, assim como apontado por Ribeiro et al. (2006), em um estudo acerca da incidência da dengue no município de São Sebastião, estado de São Paulo. Vasconcelos et al. (1993) sugerem que esta 
diferença esteja relacionada à maior permanência da mulher no interior ou ao redor da residência, quando em comparação aos homens.

Quando perguntado se há adoção de medidas que minimizem a incidência das doenças dengue e calazar, a maior parte dos participantes que afirmaram adotar alguma medida pertenciam ao bairro Missão, conforme Figura 5.

Figura 5. Comparação entre os bairros Leader Missão sobre a realização de medidas de prevenção das doenças dengue e calazar.

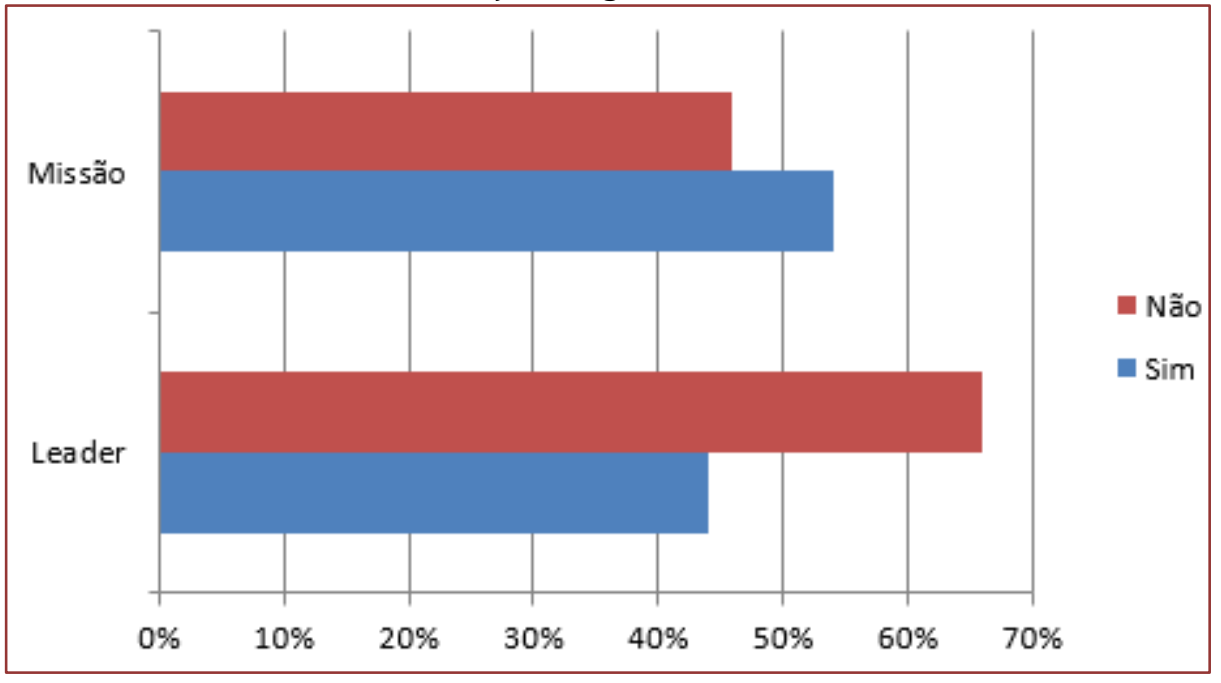

No bairro Leader, 44\% dos participantes afirmaram que realizam alguma ação de prevenção em suas residências, enquanto 66\% afirmaram não realizar. No bairro Missão, 54\% declararam que fazem ações de prevenção, enquanto $46 \%$ não o fazem. Tal fato pode estar relacionado ao menor acesso à informação dos habitantes do bairro Leader, já que, de acordo com Tauil (2002), a informação é o ponto de partida para desencadear ações de controle e prevenção de doenças. Os dados revelam uma insuficiente participação da população de ambos os bairros, que em geral possui pouco conhecimento sobre o ciclo de vida dos vetores (NOGUEIRA et al., 2009) Desta forma, o desenvolvimento de ações para disseminar informações e conhecimentos sobre as doenças seria uma ferramenta importante que contribuiria para a diminuição de focos de tais doenças.

\section{CONCLUSÕES}

A espacialização dos pontos considerados precários ou vulneráveis à proliferação dos vetores da dengue e do calazar mostrou-se uma ferramenta importante para se determinar os ambientes que direita ou indiretamente oferecem maiores riscos à saúde dos moradores, pela possibilidade de uma visão sistêmica acerca da problemática estudada.

Hoje, além das ações de prevenção e assistência, considera-se cada vez mais importante atuar sobre os fatores determinantes da saúde (GUIMARÃES et al., 2007). Diante dos resultados obtidos, salienta-se que para reduzir a ocorrência dessas doenças, é fundamental que a população tenha acesso as condições mínimas de saneamento, com água e esgoto tratado corretamente, e educação para a promoção de hábitos saudáveis de higiene.

A concretização de sistemas de saneamento básico, como a rede de esgotamento sanitário na cidade, fiscalização de terrenos baldios e casas abandonadas apresentaria um grande passo de cidadania e responsabilidade, assim como contribuiria efetivamente para o que se entende por desenvolvimento social no contexto estudado. 


\section{REFERÊNCIAS}

[1] Associação Brasileira de Normas Técnicas. NBR 6028: resumos. Rio de Janeiro, 2003. 3 p.

[2] Brasil. LEI № 11.445, DE 5 DE JANEIRO DE 2007. Diretrizes básicas nacionais para o saneamento básico. Disponível em: <http://www.planalto.gov.br/ccivil_03/_ato2007-2010/2007/lei/l11445.htm> Acesso em 10 dez 2014.

[3] Brasil. Ministério da Saúde. Secretaria Municipal de Saúde - SEMUSA. Jacobina, 2015.

[4] Facincani, Claudinei. A utilização do Google Earth na disciplina de geografia: Cuiabá - MT, Ed. UAB; p. 02 - 28 : 2011.

[5] Freitas, A. S. F; Silva, R. R; Fernandes, M. C. Google Earth e alfabetização cartográfica: Uma metodologia possível no ensino fundamental. In: Anais XVI Simpósio Brasileiro de Sensoriamento Remoto - SBSR, Foz do Iguaçu, PR, Brasil, 13 a 18 de abril de 2013: INPE; p 2569 - 2574.

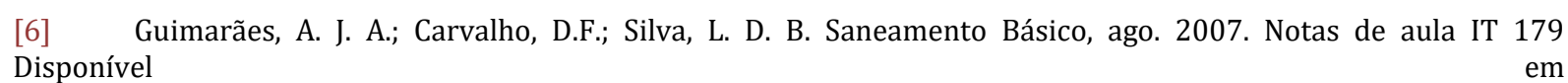
Disponível http://www.ufrrj.br/institutos/it/deng/leonardo/downloads/APOSTILA/Apostila\%20IT\%20179/Cap\%204\%20part e\%20 3.pdf. Acesso em $10 \mathrm{dez} 2014$.

[7] Ibge. Pesquisa de saneamento básico. 2010. Disponível em: <http:// www.ibge.gov.br/home/estatistica/populacao/condicaodevida/pnsb2008/PNSB_2008.pdf>. Acesso em: 09 dez 2014.

[8] Mendonça, F. Diagnóstico e análise ambiental de microbacia hidrográfica: proposição metodológica na perspectiva do zoneamento, planejamento e gestão ambiental. Revista RA' E GA O Espaço Geográfico em Análise. n.03, ano III. Curitiba: Ed. UFPR, 1999.

[9] Nogueira, R. M. R.; Nazareno, C. F.; Schatzmayr, H. G. Flaviviroses: dengue, febre amarela e outras doenças. In: Marcondes, C. B. (Org.). Doenças transmitidas e causadas por artrópodes. São Paulo: Atheneu, 2009.

[10] Oms Organização Mundial da Saúde. Disponível em: <http://www.who.int/eportuguese/publications/pt/> Acesso em 09 dez 2014.

[11] Prosab. Tratamento, Recuperação e Disposição Integrados de Resíduos Urbanos, Com Ênfase na Proteção dos Corpos D’Água. Florianópolis, 2006.

[12] Ribeiro, A. F. et al. Associação entre incidência de dengue e variáveis climáticas. In: Revista Saúde Pública, São Paulo, v. 40, n. 4, p. 671-676, 2006.

[13] Tauil, Pedro Luiz - Aspectos de controle do dengue no Brasil. In: 2002.

[14] Tauil, Pedro Luiz - Perspectivas de controle de doenças transmitidas por vetores no Brasil. In: Revista da Sociedade Brasileira de Medicina Tropical, p. 275-277, Mai-Jun, 2006.

[15] Vasconcelos, P. F. C. Epidemia de febre clássica de dengue causada pelo sorotipo 2 em Araguaína, Tocantins, Brasil. Rev. Inst Med Trop São Paulo. 1993; 35:141-8. 


\title{
Capítulo 13
}

\section{A saúde como direito de cidadania e a questão das populações tradicionais em áreas ambientalmente protegidas}

\author{
Rodrigo Ceregatti Franco \\ Cindy Carolina Benedetti Fedocci \\ Lucas Pereira da Silva Freitas \\ Duarcides Ferreira Mariosa
}

Resumo: Fundamentado nas experiências e no conjunto de estudos publicados pelos pesquisadores do Grupo de Pesquisa Biotupé, que atua na Reserva de Desenvolvimento do Tupé, Manaus, Amazonas, desde 2001, o presente texto tem por objetivo apresentar um estudo de reflexão teórica, de base documental, apoiado na leitura de documentos selecionados por sua relevância e importância para a compreensão do conceito de direito à saúde, quando problematizado à luz de questões envolvendo povos e populações tradicionais em áreas ambientalmente protegidas. Se no espaço urbano a proximidade entre as pessoas, a concentração de recursos humanos, materiais e financeiros, e a velocidade e intensidade da troca de informações permitem que o direito de acesso à saúde seja efetivado em melhores condições, qualidade e quantidade que em espaços rurais, áreas de floresta ou em reservas ambientais, por sua vez, em áreas isoladas, de difícil equilíbrio biótico, geológico ou hidrológico, povos e populações tradicionais mostram-se vulneráveis em um amplo espectro de garantias sociais e direitos constitucionais, particularmente no que se refere ao direito de acesso à saúde. Na contiguidade de espaços compartilhados por grupos populacionais tradicionais e não tradicionais, especialmente em áreas protegidas periurbanas, como a da Reserva de Desenvolvimento Sustentável do Tupé em relação a Manaus, as situações de vulnerabilidade e de impacto socioambiental se apresentam com grande intensidade e persistência. Ao enfatizar a incompatibilidade existente em áreas protegidas entre preservar os modos de existência de povos e populações tradicionais, e garantir o acesso integral à saúde como direito de cidadania, 0 artigo não propõe uma solução, mas diante da precariedade dos equipamentos e serviços oferecidos na área da reserva, indaga sobre uma realidade que deveria se estruturar de outro modo, isto é, na confluência dos objetivos de preservação, sustentabilidade e qualidade de vida, valorizando o conhecimento local, mas também proporcionando o acesso destas pessoas aos direitos de cidadania, especialmente o de acesso à saúde.

Palavras Chave: Direito à Saúde; Sustentabilidade; Povos Tradicionais.

Esta é uma versão atualizada do trabalho originalmente apresentado no V SICASA, conforme: FRANCO, R. C.; FEDOCCI, C. C. B.; FREITAS, L. P. S.; MARIOSA, D. F.. SAÚDE COMO DIREITO DE CIDADANIA PARA OS POVOS E POPULAÇÕES TRADICIONAIS. In: V Seminário Internacional em Ciências do Ambiente e Sustentabilidade na Amazônia, 2018, Manaus - AM. Anais do Seminário Internacional de Ciências do Ambiente e Sustentabilidade na Amazônia. Recife-PE: Even3, 2018. p. 01-11 


\section{INTRODUÇÃO}

As reflexões e os encaminhamentos propostos neste texto fundamentam-se nos estudos realizados pelo Grupo de Pesquisa Biotupé. 0 Biotupé é formado por pesquisadores, professores e estudantes, com as mais diversas formações acadêmicas, institucionalmente apoiados pelo Instituto Nacional de Pesquisas da Amazônia (INPA), e que desde 2001 desenvolvem projetos científicos na Reserva de Desenvolvimento Sustentável do Tupé (REDES do Tupé).

Localizada na Amazônia brasileira, à margem esquerda do Rio Negro, a REDES do Tupé é uma área de proteção ambiental inscrita na zona rural de Manaus, oficialmente criada pelo Decreto Municipal $n^{\circ}$. 8044, de 25 de agosto de 2005. Com cerca de 12.000 hectares de área, mesmo territorialmente espaçosa são poucos os moradores fixos no perímetro da reserva. Algo em torno de 1800 pessoas, distribuídas em seis núcleos comunitários, sendo cinco de comunidades ribeirinhas (Tatulândia, São João do Tupé, Julião, Livramento e Agrovila), e uma de assentamento rural (Central). Por força da legislação que ali vigora, morar e viver em uma área de preservação ambiental tem, para essas pessoas, imperativos diferentes dos que se aplicam às populações situadas em áreas não protegidas.

A lei no 9985/2000, que regulamenta o art. 225, § 10, incisos I, II, III e VII da Constituição Federal e institui o Sistema Nacional de Unidades de Conservação da Natureza, no Art. 20 indica que uma Unidade de Conservação do tipo "Reserva de Desenvolvimento Sustentável" é uma área natural que abriga populações tradicionais, cuja existência baseia-se em sistemas sustentáveis de exploração dos recursos naturais, desenvolvidos ao longo de gerações e adaptados às condições ecológicas locais, e que desempenham um papel fundamental na proteção da natureza e na manutenção da diversidade biológica (BRASIL. MINISTÉRIO DO MEIO AMBIENTE, 2000). Neste contexto, a Reserva de Desenvolvimento Sustentável do Tupé - REDES do Tupé, conforme o Decreto Municipal nº 8044 que a criou, tem como objetivo, além de preservar o ambiente natural, garantir as condições e os meios necessários para a reprodução, melhoria da qualidade de vida de seus moradores e dos modos de exploração dos recursos naturais trazidos pelas populações tradicionais, valorizando, conservando e aperfeiçoando o conhecimento e as técnicas de manejo dos recursos naturais por elas desenvolvidos (MANAUS, 2005).

Entre as muitas possibilidades e definições encontradas na literatura, Rinaldo Arruda (1999, p. 92) referese às populações tradicionais como "grupos humanos culturalmente diferenciados que historicamente reproduzem seu modo de vida, de forma mais ou menos isolada", adotando "modos de cooperação social e formas específicas de relações com a natureza, caracterizados tradicionalmente pelo manejo sustentado do meio ambiente". Esta definição, continua o autor, abrange tanto os "povos indígenas quanto os segmentos da população nacional que desenvolveram modos particulares de existência, adaptados a nichos ecológicos específicos". Exemplos de populações tradicionais são, assim, "as comunidades caiçaras, os sitiantes e roceiros tradicionais, comunidades quilombolas, comunidades ribeirinhas, os pescadores artesanais, os grupos extrativistas e indígenas". Já entre as populações não-tradicionais, estariam, para o autor, "os fazendeiros, veranistas, comerciantes, servidores públicos, empresários, empregados, donos de empresas de beneficiamento de palmito ou outros recursos, madeireiros, etc." que, embora muitas vezes vivendo no mesmo espaço protegido que as populações tradicionais, não recebem o amparo legal para suas atividades, direitos específicos a recursos da biodiversidade, ou possibilidade de uso e reforço do conhecimento e dos saberes locais.

\subsection{BJETIVO GERAL}

Grupos vulneráveis são os contingentes populacionais de uma sociedade que se encontram enfraquecidos, incapacitados ou mesmo impossibilitados de atender por si mesmos suas necessidades, ou de fruir das conquistas sociais e dos benefícios de cidadania que o Estado deve garantir, indistintamente, a todos os seus cidadãos (AYRES et al., 2006; DE LANGE et al., 2010). Na contiguidade de espaços compartilhados por grupos populacionais tradicionais e não tradicionais, especialmente em áreas protegidas periurbanas, como a da REDES do Tupé em relação a Manaus, situações de vulnerabilidade se apresentam com grande intensidade e persistência. Nesta comunicação, mediante recursos epistemológicos, conceituais e metodológicos das Ciências Sociais e das Ciências Sociais Aplicadas, reflete-se teoricamente sobre o direito à saúde como um direito humano fundamental, delimitando as discussões sobre a sustentabilidade de tal direito quando aplicado a povos tradicionais e/ou populações vulneráveis residentes em áreas ambientalmente protegidas. 


\subsection{BJETIVOS ESPECÍFICOS}

Três momentos distintos sustentam essa reflexão teórica: o direito à saúde como direito fundamental de cidadania; o direito à saúde sob a perspectiva do ciclo de vida das políticas públicas e as possíveis condições de sustentabilidade desta política; e a saúde como direito de cidadania para os povos e populações tradicionais em áreas ambientalmente protegidas.

\section{METODOLOGIA}

Trata-se de um estudo de reflexão teórica, de base documental, apoiado na leitura de documentos selecionados por sua relevância e importância para a compreensão do conceito de direito de acesso à saúde, quando problematizado à luz de questões envolvendo a vulnerabilidade dos povos e populações tradicionais, e nos estudos realizados pelo Grupo de Pesquisa Biotupé. Para maior clareza da exposição o texto foi dividido em três partes. Inicia-se com as reflexões acerca da saúde enquanto um direito de cidadania e sua efetivação a partir do Sistema Único de Saúde. Estando este inserido no modelo econômico vigente, pensa-se, a partir de leituras no campo da sustentabilidade, a garantia de sua efetivação. Apresenta-se, em seguida, as condições de acesso à saúde para os povos e populações tradicionais na REDES do Tupé para, então, discutir o papel dos profissionais das Ciências Sociais e do Serviço Social em garantir sua efetividade não apenas centrada no cuidado com o corpo, mas na atenção ao indivíduo. Por fim, para se pensar a garantia do direito à saúde em comunidades cuja reprodução da vida social difere dos valores propagados pelo modelo ocidental, propõe-se uma reflexão acerca de conceito de curadoria enquanto perpetuação dos saberes historicamente constituídos, visando a manutenção das tradições e da vida local, sendo papel do SUS a efetivação do acesso ao direito integral à saúde, preconizado pela Constituição de 1988 e pela Declaração Universal dos Direitos Humanos de 1948.

\section{A SAÚDE COMO DIREITO E SUSTENTABILIDADE}

O Estado brasileiro está constitucionalmente organizado de forma republicana e democrática. Sob a perspectiva republicana vigora o princípio da isonomia legal. Ninguém, qualquer que seja sua condição ou status econômico, cultural e social, pode estar fora, acima ou abaixo do que prescreve o ordenamento jurídico. Na perspectiva democrática, por sua vez, a legitimidade resulta do consenso estabelecido entre grupos, classes ou posições, cujo status econômico, cultural ou social encontra-se diferenciado ou hierarquicamente desigual em relação ao acesso e desfrute dos recursos socialmente produzidos (FIUZA; COSTA, 2007). Para resolver esta situação aparentemente contraditória, o conjunto de direitos de cidadania, ou seja, aqueles que permitem acesso às liberdades de natureza civil e política e aos recursos econômicos e sociais necessários e disponíveis à população, estão assegurados no texto constitucional e socialmente reconhecidos a partir de políticas públicas e/ou sociais específicas nas ações e práticas de governo (DI GIOVANNI, 2008).

Dentre os recursos econômicos e sociais cujo acesso é garantido constitucionalmente no Brasil, está o direito à saúde. 0 direito à saúde consta da Constituição de 1988 que, seguindo orientação propugnada pela Organização Mundial da Saúde (OMS), propõe em seu Art. 196, que "a saúde é direito de todos e dever do Estado, garantido mediante políticas sociais e econômicas que visem à redução do risco de doença e de outros agravos e ao acesso universal e igualitário às ações e serviços para sua promoção, proteção e recuperação" (BRASIL, 2014). 0 texto da Constituição de 1988, nos termos de Estado Democrático de Direito, compreende questões ligada à cidadania, dignidade e soberania popular, com destaque para o significado de saúde enquanto condições de trabalho, moradia, educação, lazer e acesso à serviços, em geral, escassas em áreas longínquas dos grandes centros urbanos (BRITO-SILVA; BEZERRA; TANAKA, 2012). Assim, a garantia do direito à saúde estende-se, também, na garantia de outros direitos, tais como à privacidade, à igualdade, à liberdade, o direito à vida, ao ambiente, à moradia, à educação e assistência social, entre outros tratados no texto da Lei.

Na confluência, dinamismo e interação dos domínios ambiental, econômico e social aflora a necessidade de debater conceitualmente a noção de sustentabilidade processual da saúde (JACOBI, 2003).

A primeira questão quando diferentes setores sociais tratam sobre a extensão dos direitos à saúde é seu custo econômico. Como saúde é um bem cuja manutenção demanda investimentos contínuos e de alto valor, têm-se discursos que insistem na privatização dos serviços, sua redução ou delimitação sociodemográfica, o que dificultaria, sob diferentes formas, o acesso para os econômica e ambientalmente mais frágeis (DA SILVA, 2012). 
Quanto às dimensões social e ambiental da sustentabilidade da saúde, diante das questões emergentes na atualidade, Amélia Cohn propõe uma discussão para o campo da saúde que se debruce sobre "a nova lógica de relação entre o público e o privado [...], e sua articulação com o processo de acumulação do capital na contemporaneidade"(COHN, 2013, p. 234). A seu ver, a contraposição entre escassez de recursos e desenvolvimento pode ser mitigada ao se adotar uma postura sustentável frente ao problema analisado. Todavia, a garantia do direito à saúde aplicada à realidade de povos tradicionais em áreas isoladas ou de difícil acesso apresenta diversas questões próprias, particularmente as que se referem, de um lado, ao alto custo da estrutura operacional a ser disponibilizada e, de outro, aos direitos de acesso à saúde a que fazem jus (MEDEIROS, 2006). Estudando-se a realização desta demanda a partir de ações estadocêntricas, tem-se no Sistema Único de Saúde - SUS - um importante instrumento para o processamento dos problemas relativos à saúde da população brasileira (SECCHI, 2010).

Regulamentada na Lei no 8.080, de 19 de setembro de 1990, a Lei Orgânica do SUS teve entre os seus principais desafios garantir o direito à saúde a partir de uma herança nacional em que o Estado provedor de saúde era confundido com o Estado produtor de serviços públicos estatais de saúde (NORONHA; LIMA; MACHADO, 2008). Anterior à Constituição de 1988, o acesso aos serviços de saúde era restrito ao trabalhador formal, de "cidadania regulada"; e a política de saúde elaborada por tecnocratas, preocupados com a organização e o financiamento dos serviços ao invés de sua garantia e especificidade em relação às necessidades da população, ou saber se eram coerentes com a diversidade geográfica cultural e étnica, típica da situação brasileira (GUIZARDI et al., 2014). Com isso, a implantação do SUS efetivou a saúde como direito do cidadão e dever do Estado, contemplado pela realização de atendimentos que vão desde a Atenção Básica de Saúde, oferecida nas Unidades Básicas de Saúde - UBS -, até os atendimentos de alta complexidade, realizados em unidades hospitalares especialmente construídas para este fim, e ações de prevenção aos agravos, controle e fiscalização de medicamentos e monitoramento epidemiológico (PAIM; SILVA, 2010).

O SUS é entendido como uma conquista popular, de herança das reformas sanitárias de 1970, que visavam garantir a integralidade do acesso à saúde. Ou seja, integralidade enquanto a ótica no problema humano e não na otimização do processo (BRITO-SILVA; BEZERRA; TANAKA, 2012). Entretanto, as consolidações dessas conquistas encontram-se ameaçadas diante do crescimento de medidas que favorecem a privatização dos serviços, as quais reforçam o entendimento da saúde como uma mercadoria (BYDLOWSKI; WESTPHAL; PEREIRA, 2004).

Nesta reflexão, entende-se a garantia da integralidade deste direito enquanto garantia de um direito de "quarta geração", ou seja, enquanto configuração de políticas específicas, tal qual a que orienta o SUS. Para que esta integralidade ocorra sem vazios sociodemográficos, é necessária a articulação do atendimento à saúde na forma de redes, cuja composição e lógica de funcionamento ficam, entretanto, fortemente relacionadas, como sugere Cohn (2013, p. 221), "à mobilização de capital e tecnologia". Para tal, concebese sua abordagem enquanto perspectiva sustentável, ou seja, conceito aplicável a sistemas com necessidade de medidas pró-ativas, conforme pontua Sartori, Latrônico e Campos (2014, p. 11). Sustentabilidade neste sentido não deve ser compreendida enquanto estágio social, leitura clássica aplicada ao tripé Econômico, Ambiental e Social (DE OLIVEIRA et al., 2012, p. 71; NASCIMENTO, 2012, p. 64; SARTORI; LATRÔNICO; CAMPOS, 2014, p. 3), nem tampouco enquanto indicadores isolados (MIKHAILOVA, 2004), ou como uma questão de visão de gestão, de planejamento estratégico (SARTORI; LATRÔNICO; CAMPOS, 2014), mas talvez, como sugere Boff (2017), enquanto noção de unidade, do deslocamento do eixo do desenvolvimento para o da sustentabilidade, de uma sociedade sustentável, autônoma, que supere seus problemas sociais, com cidadãos participativos que tornem concreto o princípio da democracia, previstos, por exemplo, na participação popular nos Conselhos de Saúde, organizados para gerir as políticas do SUS de atendimento à saúde.

\section{AS CONDIÇÕES DE ACESSO À SAÚDE PARA OS POVOS E POPULAÇÕES TRADICIONAIS NA REDES DO TUPÉ}

Notadamente, no âmbito das Ciências Sociais e das Ciências Sociais Aplicadas discute-se a garantia e efetivação do direito à saúde, em particular a partir do Sistema Único de Saúde enquanto política pública de caráter universal, integral e equitativa (DA SILVA, 2012). A importância de políticas públicas na área da saúde, quando relacionada à vulnerabilidade de povos e populações tradicionais, inclui avaliar as condições ambientais diferenciadas em que se desenvolve. No espaço urbano, a proximidade entre as pessoas, a concentração de recursos humanos, materiais e financeiros, e a velocidade e intensidade da troca de informações permitem que o direito à saúde seja efetivado em melhores condições, qualidade e 
quantidade que em espaços rurais, áreas de floresta ou em reservas ambientais. Em áreas isoladas, de difícil equilíbrio biótico, geológico ou hidrológico, especialmente povos e populações tradicionais, todavia, apresentam-se igualmente vulneráveis em um amplo espectro de garantias sociais e direitos constitucionais, particularmente no que se refere ao direito à saúde (VELHO, 1995).

Ora, em toda a área da REDES do Tupé o atendimento de saúde à população é oferecido de modo precário, unicamente na forma de atenção primária, constituída pelas Unidades Básicas de Saúde (UBS) e Equipes de Atenção Básica, Saúde da Família e Controle de Endemias. Níveis de atenção intermediária ficam a cargo do SAMU 192 (Serviço de Atendimento Móvel as Urgência) e das Unidades de Pronto Atendimento (UPA), e o atendimento de média e alta complexidade é feito nos hospitais, todos localizados na área urbana de Manaus.

Os equipamentos de saúde não estão adequadamente distribuídos no território. Na Comunidade Livramento fica localizada uma UBS (Posto de Saúde Rural Nossa Senhora do Livramento), responsável ainda pelo atendimento das comunidades Agrovila e Julião. Na UBS é possível o atendimento básico em Pediatria, Ginecologia, Clínica Geral, Enfermagem, Odontologia e Programas de Assistência Social, mas de forma restrita e insuficiente. A equipe de profissionais é composta por 02 médicos, 03 técnicos de enfermagem, 02 dentistas, 02 agentes de saúde bucal, 06 agentes comunitários de saúde e 03 agentes de endemias, responsáveis pela prestação de inúmeros serviços, tais como: acolhimento, acompanhamento de programas sociais, aferição da pressão arterial e glicemia, atendimento a urgências básicas, consulta médica e de enfermagem, consulta odontológica, curativo, controle de malária e leishmaniose, educação em saúde, imunização (vacina), inalação, planejamento reprodutivo, visitas domiciliares, exame dermatológico, coleta de exames laboratoriais, encaminhamentos para especialidades e fornecimento de medicação básica.

Ao invés de plantonistas, em cada comunidade há apenas um agente comunitário de saúde responsável pelo atendimento de urgência à população, atendimento este que se complementa com a equipe reduzida de profissionais, que atendem de segunda a sexta na comunidade Livramento, nas quartas-feiras na comunidade Agrovila, e nas quintas-feiras na comunidade Julião. Quanto às outras comunidades da REDES do Tupé, Tatulândia e São João do Tupé, o atendimento é feito pelo Posto de Saúde Fluvial, unidade itinerante da Secretaria Municipal de Saúde, que acolhe à população ribeirinha nos mesmos moldes, equipamentos e recursos humanos que a unidade de saúde do Livramento, mas com periodicidade errática, devido a problemas com a manutenção dos equipamentos e barco, pessoal reduzido, e a sazonalidade dos níveis de água dos rios nos locais de acesso às comunidades.

\section{POSSÍvEIS CONTRIBUIÇõES PARA A GARANTIA DO DIREITO À SAÚDE PARA OS POVOS E POPULAÇÕES TRADICIONAIS}

No plano das Ciências Sociais Aplicadas, a atuação do Assistente Social, por exemplo, ocorre também de modo a promover e/ou efetivar a garantia do direito à saúde. Para esta atuação, em 2010, o Conselho Federal de Serviço Social - CFESS (CFESS, 2010 p.30) definiu entre os parâmetros para o Trabalho do Assistente Social as demandas para a área da saúde, orientando-os para "estar articulado e sintonizado ao movimento dos trabalhadores e de usuários que lutam pela real efetivação do SUS", de modo que possam "conhecer as condições de vida e trabalho dos usuários, bem como os determinantes sociais que interferem no processo saúde-doença" e, assim, "facilitar o acesso de todo e qualquer usuário aos serviços de saúde da instituição e da rede de serviços e direitos sociais". A tarefa não é simples, pois implica construir espaços, articulando com outros profissionais de saúde, com o intuito de fortalecer a participação destes e da população nas decisões que serão tomadas sobre assuntos de relevância para suas necessidades, assessorar movimentos sociais e conselhos para fortalecer tal participação, bem como viabilizar para que seja efetuado o controle, fiscalização e elaboração das políticas de saúde, aprofundando, desta forma, os direitos já adquiridos.

Ao examinar as condições locais pelo viés da garantia ao direito à saúde, compreende-se estabelecer relações que entrelaçam "características intrínsecas (perfil demográfico e estilo de vida) e extrínsecas (localização geográfica, acesso aos serviços de saúde e a influência de centros urbanos mais dinâmicos)" (MARIOSA; FERRAZ; SANTOS-SILVA, 2018, p. 1426). Em análises que compreendem regiões de reduzida infraestrutura, cuja garantia de equidade e integralidade de acesso à serviços e a atenção à saúde se tornam um desafio, tem-se um perfil específico de trabalho do profissional para a garantia da manutenção da vida social desta população. Deste modo, o profissional do Serviço Social tem como objeto da intervenção profissional a questão social, onde deve identificar as determinações sociais, econômicas e culturais das desigualdades sociais. 
Por força constitucional, o sistema público de saúde no Brasil deve se fazer presente igualmente em regiões de menor densidade populacional, assegurando mecanismos e formas de prevenção, controle e redução de fatores de risco, tais como entendido em problemas crônicos, como a diabetes, doenças cardiovasculares, alguns tipos de câncer, etc., associadas, por exemplo, ao estilo de vida moderno, "como o sedentarismo, o consumo de alimentos com alto teor de gorduras e açúcares, o tabagismo, a ingestão excessiva de álcool, o sobrepeso e obesidade, níveis alterados de pressão arterial e hiperglicemia" (MALTA et al., 2014).

A compreensão da garantia do direito à saúde deve, então, ser aplicada de modo específico em áreas isoladas a partir de estudos que compreendam suas particularidades, como sugerido por Secchi (2010), que assevera que nem toda iniciativa de identificação do problema é monopólio de atores estatais, cabendo a diversos atores a leitura dos diversos instrumentais analíticos referentes à região. Por sua vez, a compreensão da sustentabilidade do modelo brasileiro de garantia de acesso à saúde, em áreas isoladas enfrenta outra questão: sua compreensão não pode ser estática, uma vez que ocorre em diversos níveis. Há impasses na sua garantia, visto que "regiões diferentes não se utilizam dos mesmos indicadores, dados não são coletados uniformemente"(SARTORI; LATRÔNICO; CAMPOS, 2014, p. 6). Neste sentido, a pesquisa encoraja uma leitura ampliada de sustentabilidade social, amparada em mudanças qualitativas da perspectiva humana sobre as questões ambientais, tal qual uma visão dependente de dados objetivos e provas científicas.

\section{CONSIDERAÇõES FINAIS}

Na saúde, o objeto de trabalho tem um sentido restrito. Pode ser considerada a intervenção sobre o corpo, mas, em uma concepção ampliada, pode ser a produção do cuidado. Assim, quando a situação de saúde do usuário permite, o paciente "corpo" deixa de ser um objeto e passa a ser um protagonista relevante na produção do cuidado.

Essa mudança de atitudes se faz necessária, uma vez que processos políticos e econômicos podem ser agenciados também na esfera de relações individuais. Lima (2003) acredita que a educação para a sustentabilidade desenvolvida sob o signo de mercado "promete muito e realiza pouco". Pensar na questão da saúde enquanto um direito social é buscar refletir sobre a garantia desta igualdade de condições, a partir de uma sociedade mais equitativa, cabendo aos cidadãos o esforço da educação das gerações vindouras para este modelo social almejado.

Boff (2017) alerta sobre a necessidade de se incorporar preocupações sobre o local onde se vive e estimular mudanças na perspectiva humana sobre questões ambientais. Para tanto, é necessário refletir sobre o percurso tomado historicamente a partir da ideia do desenvolvimento pautado no sistema econômico vigente, propagador de desigualdades. Tomando-se por referência a garantia das liberdades individuais, percebe-se que enquanto uns usufruem mais para viver, outros ficam desamparados. Essa desigualdade estruturalmente perpetuada pode ser mitigada, a partir da integração das dimensões da vida individual e social, identificando-se com princípios democráticos e participativos, tendo na sociedade civil organizada o papel predominante no processo de transição para este modelo de sustentabilidade social.

Propõe-se, ainda, que a interlocução entre profissionais e sociedade, a partir da criação e participação em conferências e conselhos, possa devolver ao cidadão seu protagonismo social. A finalidade desta transformação visa garantir a extensão da discussão para outros ambientes sociais. Sugere-se que este paradigma poderia ser incorporado à filosofia dos profissionais que trabalham com questões de saúde da população, levando sua ação conscientizada também pelo viés cultural, ou seja, a partir da compreensão da reprodução da vida social, na redução de problemas ligados a um estilo de vida não comportado na herança cultural de povos tradicionais. Por entender ser essa uma mudança qualitativa, pensa-se que a ação coletiva poderá influir no processo de gestão, levando em última instância a uma mudança lenta, porém gradual do aparato estrutural. Neste sentido, após sua consolidação, pode-se entender a sustentabilidade da garantia do direito à saúde a partir do paradigma de Brown Weiss, ou seja, livre da noção de desenvolvimento (WEISS, 1992). Esse princípio, denominado "curadoria", entende a perpetuação de um legado, que visa a manutenção e a reprodutibilidade de uma vida social sustentável, o que condiz com a condição socioambiental, econômica, social, cultural e política das populações e povos tradicionais. 


\section{REFERÊNCIAS}

[1] Arruda, R. Populações tradicionais. Ambiente \& sociedade, n. 5, 1999.

[2] Ayres, J. R. de C. M. et al. Vulnerability, Human Rights, and Comprehensive Health Care Needs of Young People Living With HIV/AIDS. American Journal of Public Health, v. 96, n. 6, p. 1001-1006, jun. 2006.

[3] Boff, L. Sustentabilidade: o que é-o que não é. São Paulo: Editora Vozes, 2017.

[4] Brasil. Texto consolidado até a Emenda Constitucional no 77 de 11 de fevereiro de 2014. Constituição da República Federativa do Brasil. 11 fev. 2014.

[5] Brasil. Ministério do Meio Ambiente. Lei No 9.985, de 18 de julho de 2000. Sistema Nacional de Unidade de Conservação da Natureza - SNUC. . 19 jul. 2000, Sec. Brasilia - DF.

[6] Brito-Silva, K.; Bezerra, A. F. B.; Tanaka, O. Y. Direito à saúde e integralidade: uma discussão sobre os desafios e caminhos para sua efetivação. Interface - Comunicação, Saúde, Educação, v. 16, n. 40, p. 249-260, 19 abr. 2012.

[7] Bydlowski, C. R.; Westphal, M. F.; Pereira, I. M. T. B. Promoção da Saúde. Porque sim e porque ainda não! Saúde e sociedade, v. 13, p. 14-24, 2004.

[8] Conselho Federal de Serviço Social. Parâmetros para atuação de assistentes sociais na política de saúde. Brasília: CFESS, 2010.

[9] Cohn, A. Saúde, cidadania e desenvolvimento. Centro Internacional Celso Furtado de Políticas para o Desenvolvimento, 2013.

[10] Da Silva, M. V. Políticas públicas de saúde: tendências recentes. Sociologia, Problemas e Práticas, v. 2012, n. 69, 19 out. 2012.

[11] De Lange, H. J. et al. Ecological vulnerability in risk assessment - A review and perspectives. Science of The Total Environment, v. 408, n. 18, p. 3871-3879, ago. 2010.

[12] De Oliveira, L. R. et al. Sustentabilidade: da evolução dos conceitos à implementação como estratégia nas organizações. Production, v. 22, n. 1, p. 70-82, 2012.

[13] Di Giovanni, G. Políticas públicas e política social.Gera Di Giovanni, 22 ago. 2008. Disponível em: <http://geradigiovanni.blogspot.com.br/2008/08/polticas-pblicas-e-poltica-social.html>. Acesso em: 3 mai. 2018

[14] Fiuza, R. A. M.; Costa, M. A. M. F. E. Aulas de teoria do Estado. Belo Horizonte: Del Rey, 2007.

[15] Guizardi, F. L. et al. Políticas de participação e saúde. Recife: Ufpe / Epsjv / Fiocruz, 2014.

[16] Jacobi, P. Educação ambiental, cidadania e sustentabilidade. Cadernos de Pesquisa, n. 118, p. 189-206, mar. 2003.

[17] Lima, Gustavo da Costa. The sustainability discourse and its implications for education. Ambiente \& Sociedade, v. 6, n. 2, p. 99-119, 2003.

[18] Malta, D. C. et al. Doenças crônicas Não transmissíveis e o suporte das ações intersetoriais no seu enfrentamento. Ciência \& Saúde Coletiva, v. 19, n. 11, p. 4341-4350, nov. 2014.

[19] Manaus. Decreto n. 8044, de 25 de agosto de 2005. Cria a Reserva de Desenvolvimento Sustentável do Tupé. Diário Oficial de Manaus.

[20] Mariosa, D. F.; Ferraz, R. R. N.; Santos-Silva, E. N. dos. Influência das condições socioambientais na prevalência de hipertensão arterial sistêmica em duas comunidades ribeirinhas da Amazônia, Brasil. Ciência \& Saúde Coletiva, v. 23, n. 5, p. 1425-1436, maio 2018.

[21] Medeiros, R. Evolução das tipologias e categorias de áreas protegidas no Brasil. Ambiente \& Sociedade, v. 9, n. 1, p. 41-64, 2006.

[22] Mikhailova, I. Sustentabilidade: evolução dos conceitos teóricos e os problemas da mensuração prática. Economia e Desenvolvimento, n. 16, 2004.

[23] Nascimento, E. P. do. Trajetória da sustentabilidade: do ambiental ao social, do social ao econômico. Estudos Avançados, v. 26, p. 51-64, 2012.

[24] Noronha, J. C. de; Lima, L. D. de; Machado, C. V. Sistema Único de Saúde-SUS. In: Políticas e sistemas de saúde no Brasil. Rio de Janeiro: Editora Fiocruz. p. 435-472, 2008.

[25] Paim, J. S.; Silva, L. M. V. DA. Universalidade, integralidade, equidade e SUS. BIS. Boletim do Instituto de Saúde (Impresso), v. 12, p. 109-114, 2010.

[26] Sartori, S.; Latrônico, F.; Campos, L. Sustainability and sustainable development: a taxonomy in the field of literature. Ambiente \& Sociedade, v. 17, n. 1, p. 01-22, 2014. 
[27] Secchi, L. Políticas públicas: conceitos, esquemas de análise, casos práticos. São Paulo: Cengage Learning, v. $133,2010$.

[28] Velho, G. Estilo de vida urbano e modernidade. Revista Estudos Históricos, n. Query date: 2016-02-26, 1995.

[29] Weiss, E. B. Environmental change and international law: new challenges and dimensions. London - UK: United Nations University Press, 1992. 


\section{Capítulo 14}

Comparação entre métodos para identificação de larvas de geohelmintos na Baía do Pontal, Ilhéus, Bahia

\section{Geovanna Carvalho Cardoso Lima \\ Marcelo Fernandes da Silva}

Resumo: Foram observados altos índices de despejo de lixo e de esgoto improvisado em praias zona sul do município de Ilhéus-BA, o que representa risco de contaminação para geohelmintíases. Objetivo: Padronizar método para estudar contaminação de solo por larvas de geohelmintos na região litorânea sul do município de Ilhéus - Bahia. Metodologia: Empregaram-se os método Rugai Adaptado (RA) e o método Harada-Mori Modificado (HMM) atrelado a análises microscópicas e a comparação satisfatória dos resultados entre esses dois métodos, por meio de análise de variância e pós-testes $t$ de Student, Tukey ou Bonferroni. Principais Resultados: Confirmação acerca da contaminação de solo por larvas de geohelmintos, especialmente por Strongyloides stercoralis na praia do Me Ache e de Ancylostoma spp. nas praias da Zona Sul, sendo o método HMM responsável pela identificação de maior quantidade de larvas de $\mathrm{S}$. stercoralis, mas o que apresentou menor sensibilidade para as demais larvas. Também não foi possível identificar larvas ambientais pelo método HMM. Principais conclusões: Ambos os métodos são de valor para quantificação de larvas de geohelmintos a partir de amostras de areia de praia, e que novos protocolos devem ser testados para melhor análise do método HMM.

Palavras-chave: Contaminação; Meio Ambiente; Saúde; Inovação; Racionalidade. 


\section{INTRODUÇÃO}

A areia é reconhecida pela Organização Mundial da Saúde (OMS) como vetor de várias infecções (PEREIRA et al., 2013). As areias das praias estão sujeitas à contaminação frequente por diversos microrganismos patogênicos provenientes de diversas fontes como lixo, animais domésticos e dejetos humanos (PULLAN et al., 2014; SOLO-GABRIELE et al, 2016). Essa contaminação pode ser considerada um risco a saúde dos banhistas, causando-lhes agravos entre os quais, as geohelmintíases, que necessitam do solo para completar seu ciclo evolutivo. Importantes cidades cujo atrativo para o turismo é a exploração de praias e rios devem oferecer balneabilidade para garantir a mínima exposição humana a contaminantes. Nesse sentido, a adoção de medidas de controle da contaminação, não só de rios e praias, mas do solo, deve ser um objetivo da gestão pública. O saneamento precário ou insuficiente é fator contribuinte na contaminação por geohelmintos (PULLAN et al., 2014; SOLO-GABRIELE et al, 2016). Assim, a presença ou não de larvas de geohelmintos na areia das praias depende de condicionantes como as ações antropogênicas e a variabilidade climática (SILVA et al., 2017).

Objetiva-se com o trabalho vigente, a padronização do método HMM para confirmar a presença de geohelmintíases na região litorânea sul do município de Ilhéus localizado no sul da Bahia, em cinco áreas desta região (desde a praia Me Ache até a praia Cururupe); a aplicabilidade do método RA juntamente com o método HMM para processamento em laboratório especializado, atrelado à análise microscópica para fins comparativos, teve a finalidade de atribuir maior reprodutibilidade e precisão nos métodos empregados para diagnosticar a presença dos geohelmintos nos sedimentos das praias, associando ao risco de contaminação na zona sul no município de Ilhéus.

\section{METODOLOGIA}

A definição das áreas de coleta levou em consideração as praias frequentadas por banhistas e moradores da zona urbana de Ilhéus (Baía do Pontal), a proceder à coleta nas praias do Me Ache (Área I), AABB até o Sítio São Paulo (Área II), Jardim Atlântico até o Loteamento Pérola do Mar (Área III), e de lá até condomínio Cidadelle (Área IV) e até praia Cururupe (Área V), sendo coletadas 36 amostras em cada área. Cada área foi dividida em duas subáreas, as quais foram marcadas para remoção do sedimento utilizandose um trado com alcance de $20 \mathrm{~cm}$ de profundidade. Os dados foram analisados inicialmente pelo teste ANOVA e com pós-testes, para comparação entre as médias e desvios-padrão da quantidade de larvas encontradas, como o teste $t$ de Student, o teste $t$ de Tukey e o teste de Bonferroni.

\section{RESULTADOS E DISCUSSÃO}

Na Tabela 1 estão resumidos os resultados em todas as coletas, de acordo com a Área de Estudo, peso bruto (g) da areia, e quantidade larvas dos principais geohelmintos encontrados. Foram obtidas no total 145.934g de areia (35.902g da Área I, 21.837g da Área II, 37.273g da Área III, 31.805g da Área IV e $19.117 \mathrm{~g}$ da área V). Ao processar as amostras coletadas pelo método HMM (Tabela 1a), foram encontradas no total $\mathrm{n}=295$ larvas, sendo $\mathrm{n}=57$ larvas da espécie Ancylostoma spp., $\mathrm{n}=238$ larvas Strongyloides stercoralis e nenhuma larva ambiental.

Assim como foi descrito acima para o método HMM, também foram contabilizados resultados para o método RA (Tabela 1b). Foram encontradas no total $n=634$ larvas, sendo $n=191$ larvas da espécie Ancylostoma spp., $\mathrm{n}=312$ larvas de Strongyloides stercoralis e n=138 larvas ambientais. 
Tabela 1: Quantidade de larvas de geohelmintos e peso das amostras.

\begin{tabular}{|c|c|c|c|c|c|}
\multicolumn{7}{c|}{ a) } & \multicolumn{2}{c|}{ HMM } & $\begin{array}{c}\text { Ancylostom } \\
\text { a spp. }\end{array}$ \\
\hline \multirow{2}{*}{ Área de Estudo sd Peso } & Peso Bruto (g) & \multicolumn{2}{c|}{$\begin{array}{c}\text { Larvas } \\
\text { Totais (n) }\end{array}$} & S stercoralis & 45 \\
\hline I & 35.902 & $804,4 \pm 186,3$ & 255 & 210 & 0 \\
\hline II & 21.837 & $1131,8 \pm 158,9$ & 3 & 3 & 1 \\
\hline III & 37.273 & $849,7 \pm 91,5$ & 1 & 0 & 8 \\
\hline IV & 31.805 & $936,7 \pm 62,2$ & 33 & 25 & 3 \\
\hline V & 19.117 & $1253,3 \pm 187,0$ & 3 & 0 & 57 \\
\hline Total & 145.934 & $1020,2 \pm 229,0$ & $295^{*}$ & 238 & \\
\hline
\end{tabular}

b) RA

\begin{tabular}{|c|c|c|c|c|c|}
\multirow{2}{*}{ Área de Estudo } & Peso Bruto (g) & $\begin{array}{c}\text { X } \pm \text { sd Peso } \\
\text { Amostral (g) }\end{array}$ & $\begin{array}{c}\text { Larvas } \\
\text { Totais (n) }\end{array}$ & S stercoralis & $\begin{array}{c}\text { Ancylosto } \\
\text { ma spp. }\end{array}$ \\
\hline I & 35.902 & $804,4 \pm 186,3$ & 193 & 107 & 48 \\
\hline II & 21.837 & $1131,8 \pm 158,9$ & 151 & 99 & 23 \\
\hline III & 37.273 & $849,7 \pm 91,5$ & 173 & 57 & 70 \\
\hline IV & 31.805 & $936,7 \pm 62,2$ & 79 & 24 & 15 \\
\hline V & 19.117 & $1253,3 \pm 187,0$ & 38 & 25 & 191 \\
\hline Total & 145.934 & $1020,2 \pm 229,0$ & $634^{* *}$ & 312 & \\
\hline
\end{tabular}

A Figura 2 apresenta os resultados da correção da quantidade de larvas de acordo com o peso em gramas $(1000 \mathrm{~g})$ para todas as amostras coletadas. É possível notar que houve maior quantidade larvas de $S$. stercoralis nas amostras I e IV quando processadas pelo método HMM ( $p<0,001$ Teste de Tukey). No método RA, foi possível verificar a presença de larvas de $S$. stercoralis em quase todas as amostras, significativamente nas Áreas I $(p<0,05)$ e III $(p<0,001)$. A quantidade de larvas de Ancylostoma spp. foi maior nas Áreas III e IV quando se utilizou o método RA, principalmente quando a quantidade de larvas foi ajustada para $1000 \mathrm{~g}$ de areia em todas as amostras.

Figura 2: a) Quantidade de larvas considerando a média do peso bruto (g) das amostras coletadas. b) Quantidade de larvas expressas corrigindo-as em função da média de peso das amostras coletadas.

a) Peso Bruto - Método HMM

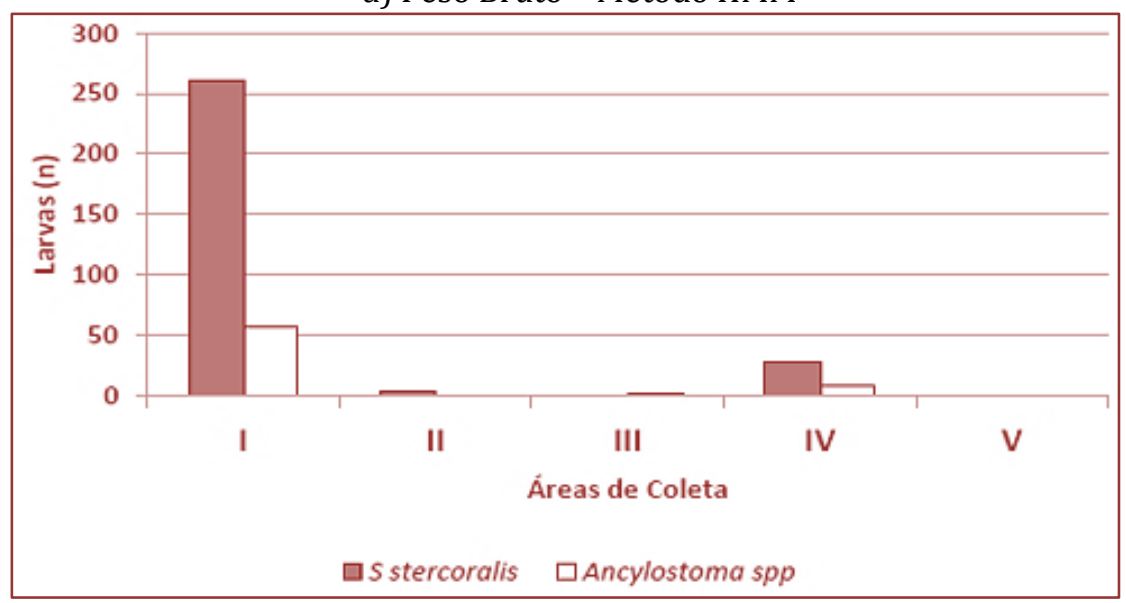


b) Peso Corrigido - Método RA

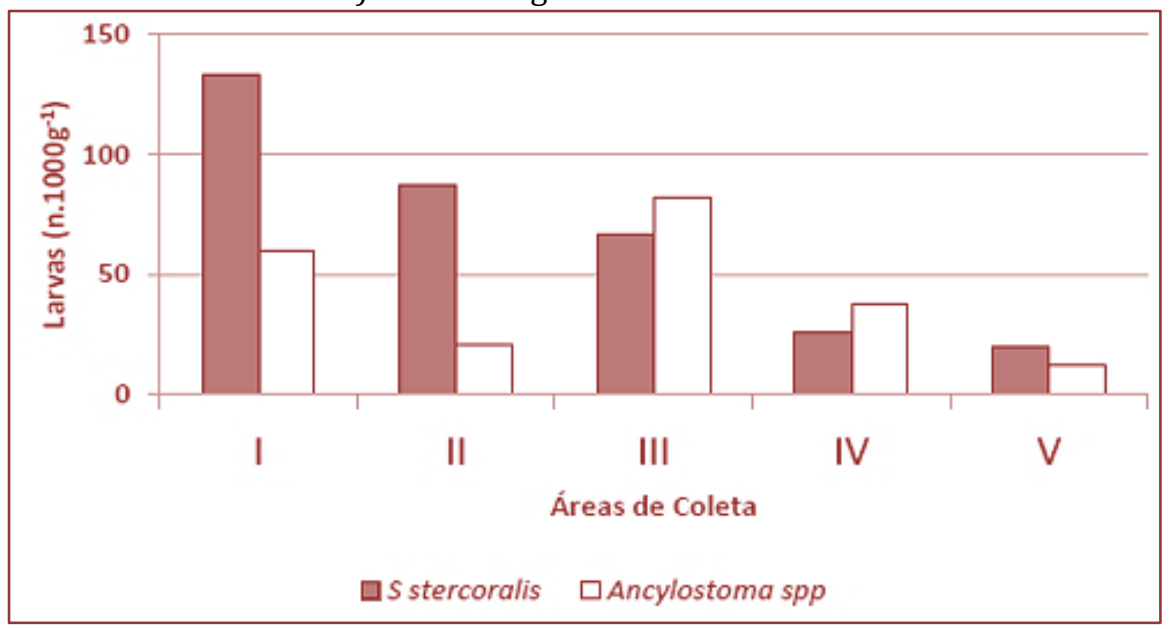

O significado estatístico destas diferenças entre as médias da contagem de larvas em cada área de acordo com cada método pode ser visto na Figura 3. Com isso, foi possível verificar que, independentemente do método empregado, as larvas de S. stercoralis foram mais frequentes na Área I (praia do Me Ache), que tem descarte inadequado de resíduos e esgoto doméstico diretamente na areia (SILVA et al, 2017). Uma maior quantidade de Ancylostoma spp. foi observada nas praias com superfície mais plana, onde maior fluxo de pessoas e animais de estimação já foram encontrados (SILVA et, 2017).

Figura 3: Método RA. Quantidade de larvas de geohelmintos encontrada nas diferentes áreas de coleta. Peso corrigido para $1000 \mathrm{~g}$; Teste $t$ de Student, Tukey e Bonferroni, para comparação entre duas, mais que duas e entre todas as médias encontradas, respectivamente com $5 \%$ de significância.

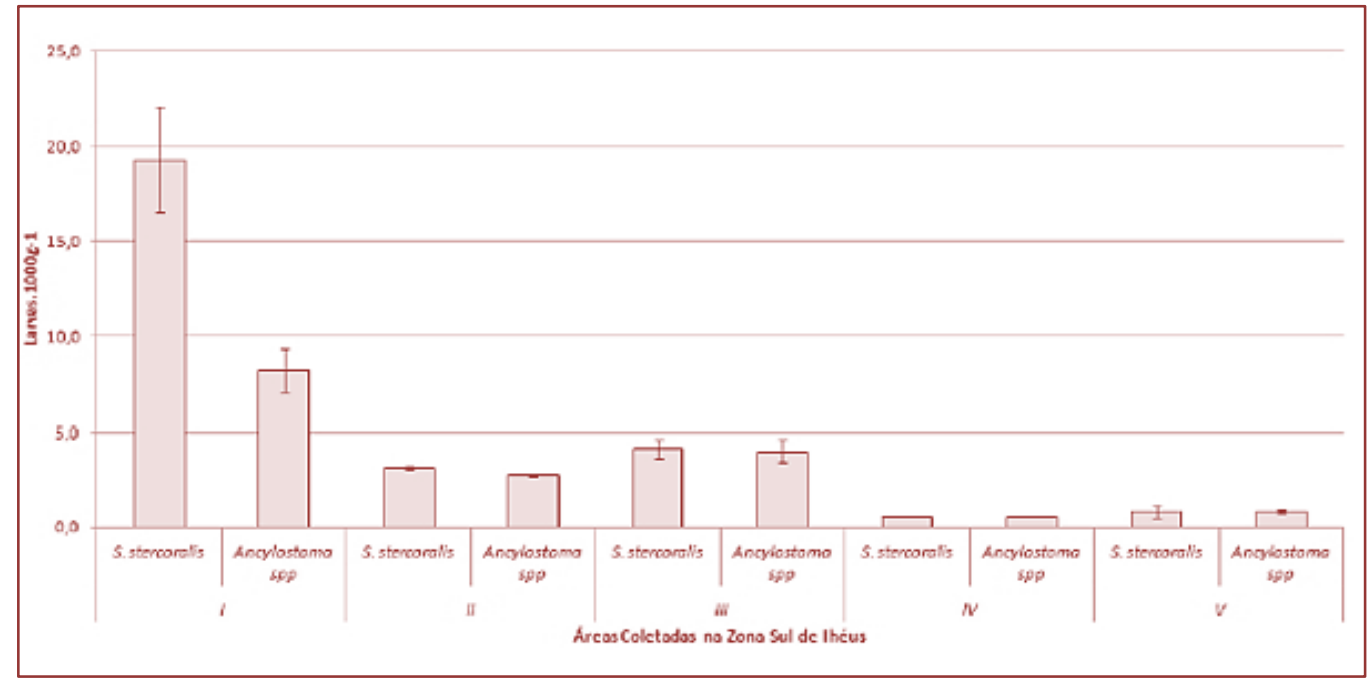

\section{CONCLUSÕES}

Portanto, é possível observar que o método HMM produziu, na Área I, II e III, maior predominância de larvas do gênero Strongyloides stercoralis, enquanto que na Área IV e V, maior predominância de larvas do gênero Ancylostoma spp. A comparação preliminar entre os dois métodos utilizados, revela que o RA foi mais sensível em isolar as larvas de geohelmintos do que o HMM, porém, larvas ambientais somente foram encontradas no RA. 


\section{REFERÊNCIAS}

[1] Pereira E, Figueira C, Aguiar N, Vasconcelos R, Vasconcelos S, Calado G, et al. Microbiological and mycological beach sand quality in a volcanic environment: Madeira archipelago, Portugal. Sci Tot Environ 2013; 461, 469-479.

[2] Pullan RL, Smith JL, Jasrasaria R, Brooker SJ. Global numbers of infection and disease burden of soil transmitted helminth infections in 2010. Parasit Vectors 2014; 7:37-56.

[3] Silva YS, da Silva JMS, Castro RC, Dias SO, Carvalho SMS, Silva MF. Environmental Parasitology: Analysis of the Contamination of Soil By Larvae of Geohelminths in Ilhéus, Bahia. Rev Patol Trop 2017; 46 (3): 253-262.

[4] Solo-Gabriele HM, Harwood VJ, Kay D, Fujioka RS, Sadowsky MJ, Whitman RL et al. Beach sand and the potential for infectious disease transmission: observations and recommendations. J Mar Biol Assoc UK 2016; 96(1): 101-120. 


\section{Capítulo 15}

Uma contribuição na análise de viabilidade econômica, social e ambiental no uso do lodo de esgoto na agricultura do Distrito Federal

\section{Marcos de Lara Maia \\ Gustavo Macedo de Melo Baptista}

Resumo - A destinação final dos resíduos das Estações de Tratamento de Esgoto (ETE) é uma crescente preocupação mundial. O lodo de esgoto é um produto orgânico do sistema de tratamento de esgoto, potencialmente contaminante, mas que pode ser viável sua utilização de maneira benéfica como na reciclagem agrícola. Devido o lodo de esgoto ser fonte de vários nutrientes (nitrogênio, fósforo, potássio, cálcio, magnésio, enxofre e micronutrientes) e matéria orgânica, a sua reciclagem agrícola ganhou importância estratégica como uma alternativa bem viável para a sua disposição final. A reciclagem agrícola reside na incorporação do lodo de esgoto no solo proporcionando níveis mínimos de matéria orgânica necessários no controle de erosão, na manutenção da produtividade, na recuperação de áreas e solos degradados. Contudo, a viabilidade do uso do lodo de esgoto na reciclagem agrícola depende de fatores sanitários, ambientais, agronômicos e, principalmente, de sua aceitação perante os produtores agrícolas e dos consumidores finais de alimentos produzidos com adubo do lodo de esgoto. A identificação precisa e objetiva das questões econômicas, sociais e ambientais deste passivo ambiental chamado lodo de esgoto dará subsídios necessários para o aperfeiçoamento do planejamento e da gestão pública, que, quando bem aplicado, oferece indicadores que ajudam na condução da tomada de decisão. Esse trabalho propõe apresentar uma contribuição na análise da viabilidade econômica, social e ambiental no uso do lodo de esgoto na agricultura do Distrito Federal.

Palavras-chave: lodo de esgoto, aceitação, rejeição, valoração contingente. 


\section{INTRODUÇÃO}

O lodo de esgoto é subproduto do tratamento de esgotos, podendo, em princípio, conter qualquer substância que exista na área de drenagem da Estação de Tratamento de Esgotos (ETE) em que ele foi produzido. A composição dos esgotos varia enormemente em função do local de origem, por exemplo, se de uma área tipicamente residencial ou industrial, da época do ano e do nível social da comunidade (TSUTIYA, 2001).

O destino final dos resíduos das estações de tratamento de esgotos é uma crescente preocupação mundial, com reflexos na disponibilidade e na qualidade da água para consumo e atividades econômicas. 0 lodo de esgoto é um produto orgânico do sistema de tratamento de esgotos que pode ser usado de maneira benéfica por ser rico em matéria orgânica e nutrientes (nitrogênio, fósforo, potássio, cálcio, magnésio, enxofre e micronutrientes), tendo potencial de uso na reciclagem agrícola como condicionador de solo e fonte suplementar de nutrientes e matéria orgânica.

Além de solucionar o atual passivo ambiental, a sua utilização como fonte de nutrientes vem substituir as atuais fontes dos adubos químicos que são provenientes dos recursos naturais. 0 acúmulo desse produto nos pátios das ETEs constitui mais uma ameaça ao ambiente, caso não sejam encontradas alternativas viáveis do ponto de vista social, econômico e ambiental para o seu uso benéfico.

Conforme já afirmavam Tsutya (2001) e Silva et al. (2000), a reciclagem agrícola é uma alternativa muito viável para a disposição final do lodo, mas com as devidas precauções quanto nos quesitos relacionados aos aspectos econômicos, à saúde pública e à proteção ambiental.

Para Corrêa e Corrêa (2001), o lodo de esgoto na reciclagem agrícola traz benefícios como condicionador de solos que auxiliará no controle de erosão, na manutenção da produtividade e na recuperação de áreas e solos degradados. Além do mais, no Bioma Cerrado, as condições de temperatura e de umidade aceleram os processos de decomposição da matéria orgânica resultando em solos com baixos teores deste elemento (PEREIRA et al., 1982).

A identificação precisa e objetiva das questões econômicas, sociais e ambientais deste passivo ambiental chamado lodo de esgoto dará subsídios necessários para o aperfeiçoamento do planejamento e gestão pública, que, quando bem aplicado, oferece indicadores que ajudam na condução da tomada de decisão.

\section{MATERIAIS E MÉTODOS}

A questão econômica do manejo de produtos originados do lodo de esgoto para uso na reciclagem agrícola é mais complexa, porque há uma série de custos a serem mensurados, em contraste com os benefícios econômicos que cada subproduto do lodo de esgoto pode proporcionar. Sob esta ótica, a avaliação da existência de subprodutos com valor agregado do lodo de esgoto torna-se importante por mencionar a existência de opções substitutas como norteador de um cenário futuro.

\subsection{VALORAÇÃO DE MERCADO DE BENS SUBSTITUTOS}

A valoração econômica do lodo de esgoto pelo mercado substituto foi realizada no mês de novembro de 2005, época em que existe uma maior demanda dos insumos agrícolas no DF.

0 método utilizado foi o método de valoração de bens substitutos. Seu emprego obteve-se preços de um mercado substituto e de insumo comercializado. Foram usados preços reconhecidos de mercado de vários insumos comerciais para estimar o valor econômico do lodo de esgoto.

Os insumos cotados para fontes de nitrogênio, fósforo, potássio e matéria orgânica serão uréia, superfosfato triplo, cloreto de potássio, composto de lixo do SLU/DF (Serviço de Limpeza Urbana do Distrito Federal) e cama de frango, insumos que são amplamente utilizados na agricultura. Assim, foram feitos comparações dos percentuais de cada elemento citado do lodo de esgoto com os insumos comerciais, e relacionou-se proporcionalmente com o preço de mercado destes insumos.

\subsection{VALORAÇÃO CONTINGENTE}

Em relação à valoração contingente, o trabalho foi efetuado por meio de questionários. Existem muitas formas de se montar um questionário para obter a declaração da disposição a pagar (DAP) das pessoas entrevistadas, mas, os mais utilizados são: 1- Formato aberto: A pergunta é formulada simplesmente pedindo aos entrevistados que declarem sua DAP. Este formato tem como variante expor certos leques de preços e solicitar ao entrevistado a escolha do preço que represente, de forma mais aproximada a sua DAP. Mas as questões em formato aberto têm maiores problemas estatísticos e aproxima-se menos a 
circunstâncias reais de mercado (BRUGNARO, 2000). 2- Formato de referendo: Desenvolvido por Bichop e Heberlein (1979) é também conhecido como binário, dicotômico ou fechado e é muito usado. É proposto um valor distinto para cada entrevistado, de maneira a obter uma distribuição de respostas afirmativas. As perguntas formuladas são da forma: "Você está disposto a pagar (DAP) R\$ XX?", em que o entrevistado responde com "sim" ou "não", ou manifesta não querer responder por algum motivo.

Para a presente proposta de dissertação, foram adotadas as duas opções tendo em vista que os grupos de produtores rurais conhecem o assunto que foi abordado, portanto usou-se o formato aberto, e já o grupo dos consumidores é praticamente leigo no assunto, usou-se o formato referendo.

O questionário para os produtores rurais do Distrito Federal utilizou-se de formato aberto, pois, muitos deles, já foram usuários do lodo de esgoto na agricultura e têm bastante noção de preço de mercado de adubos orgânicos (esterco de gado, cama de frango e cama de ave poedeira) utilizados na agricultura. Além do preço a pagar em aberto, o questionário abrangeu aspectos sanitários, econômicos, ambientais e de aceitabilidade do produto.

Foi adotado um universo amostral de 400 indivíduos, com margem de erro de 5\%, de uma população de 13.496 produtores do Distrito Federal.

Os questionários foram aplicados pelos técnicos da EMATER, pois estes eram os técnicos responsáveis que recomendavam o lodo de esgoto na agricultura do DF e estão distribuídos na área rural do DF em 16 escritórios (Alexandre de Gusmão, Brazlândia, Ceilândia, Gama, Jardim, Lago Oeste, PAD-DF, Paranoá, Pipiripau, Planaltina, Rio Preto, São Sebastião, Sobradinho, Taquara, Tabatinga e Vargem Bonita). Os técnicos foram orientados para aplicar parte dos questionários com produtores que já utilizaram o lodo de esgoto em suas propriedades e parte em produtores que nunca utilizaram ou mesmo nunca ouviram falar no produto.

O questionário direcionado para os consumidores do DF de frutas e hortaliças utilizou-se em formato de referendo. Este formato de questionário é mais adequado para um público que tem menos conhecimento da problemática pesquisada, pois, admite menor ocorrência de viés estratégico por parte dos entrevistados e avizinha-se da verdadeira experiência de mercado que comumente determina suas ações no consumo frente à utilização de um forte "contaminante" no manejo de produção.

Além da questão relativa à disposição do preço a pagar a mais na conta de esgoto residencial, para que o lodo de esgoto seja devidamente tratado antes de ser utilizado na agricultura ou em outras formas de manejo, o questionário também abrangeu aspectos relativos à aceitabilidade dos alimentos produzidos em solos fertilizados com lodo esgoto, problemas ambientais e econômicos.

Foi adotado um universo amostral de 400 indivíduos, com margem de erro de 5\%, considerando uma população de indivíduos do Distrito Federal. Os questionários foram aplicados no CEASA, em feiras, sacolões e supermercados buscando alcançar todas as áreas administrativas do DF com amostras proporcionais ao universo de domicílios de cada Região Administrativa do DF.

Os questionários definitivos para os consumidores e as devidas entrevistas foram realizadas com a colaboração de 3 (três) estagiários da EMATER, alunos de graduação de Engenharia Agronômica e Engenharia Ambiental da Faculdade da Terra e Universidade Católica de Brasília, respectivamente.

Utilizou-se a entrevista direta, in situ, tanto para os produtores rurais quanto para os consumidores urbanos, por ser a modalidade que se obtém o maior índice de respostas satisfatórias. Os dados foram coletados durantes os meses de fevereiro, março e abril de 2006. Esta fase da pesquisa foi dividida em três partes para o aprimoramento do questionário: (1) inicialmente, o questionário sofreu um pré-teste em dois momentos. Um primeiro questionário foi elaborado para ser aplicado aleatoriamente para 20 consumidores e 20 produtores. 0 pré-teste serviu para testar as questões contidas no questionário e para, após tabulação destes, verificar se as perguntas respondidas não estavam fora dos objetivos propostos por esta dissertação. (2) Após aprimoramento do formato do questionário, este foi aplicado aleatoriamente para mais 20 produtores e 20 consumidores do DF, para detectar eventuais erros e deficiências adicionais. 0 valor aleatório de 20 amostras foi adotado para perfazer $5 \%$ do total amostral, sendo que no total da pré-amostra perfez-se o valor de $10 \%$. (3) Após segunda correção, foi elaborada a versão final do questionário que foi utilizado na coleta de dados para 400 indivíduos de cada grupo. Para reduzir falhas que poderiam surgir no decorrer das entrevistas e, para padronizar os procedimentos a serem adotados, todo o acompanhamento do trabalho foi supervisionado pelo dissertando, desde o treinamento com os entrevistadores, até a fase da entrevista. 
O problema e a metodologia adotada foram apresentados visando à correta interpretação do conteúdo do questionário; adequada seleção (aleatória) de pessoas a serem entrevistadas; e o comportamento durante a abordagem e as entrevistas pessoais. Durante a etapa de levantamento de dados, os entrevistadores mantiveram comunicação constante e ativa visando o monitoramento e recepção dos questionários aplicados.

\subsection{O CÁLCULO DA AMOSTRA}

Para o cálculo da amostra (n), foi utilizada a fórmula: $n=1 / E^{2}$; A fórmula utilizada foi baseada no erro amostral tolerável (E), que foi de $5 \%$ para esta pesquisa. Portanto, não foi levado em conta o tamanho $\mathrm{N}$ da população, para o caso que a população seja muito grande (dezenas de milhares de indivíduos, por exemplo). No caso específico desta pesquisa, como se conhece o tamanho da população de indivíduos, a população de produtores do DF é de 13.496 indivíduos e a população do DF é de 2.000 .000 de habitantes, corrigiu-se em função do seu tamanho $(\mathrm{N})$, fazendo $n=\left(\mathrm{N}^{*} \mathrm{n} 0 / \mathrm{N}+\mathrm{n} 0\right)$, em que n0 é o tamanho da amostra. Sendo que o universo amostral encontrado foi de 400 produtores e 400 consumidores urbanos do DF.

\section{RESULTADOS E DISCUSSÃO}

\subsection{VALORAÇÃO DO LODO DE ESGOTO}

O lodo de esgoto fresco da CAESB, com conteúdo de água de 84\%, apresentou valor de R 25,36 a R\$27,32 por tonelada, considerando, exclusivamente, o custo de reposição dos elementos nitrogênio, fósforo, potássio e matéria orgânica. Esta faixa de preço ocorreu por trabalhar com duas fontes de matéria orgânica, cama de frango (R \$ 3,48) e o adubo do "SLU" (R\$ 1,52). A caracterização química de amostra de lodo de esgoto da ETE-Norte analisada pela CAESB revelou 55 g kg-1 de N, 30 g kg-1 de P e 3 g kg-1 de K, em base seca; os valores de ureia $(0,45 \mathrm{~kg}$ de $\mathrm{N}$ kg-1), do superfosfato triplo $(0,18 \mathrm{~kg}$ de $\mathrm{P} \mathrm{kg}-1)$, do cloreto de potássio (0,58kg de K kg-1) foram respectivamente de $\mathrm{R} \$ 940,00, \mathrm{R} \$ 720,00$ e $\mathrm{R} \$ 676,00$ por tonelada. Esses valores representam a realidade do mercado formal, em 13 de novembro de 2005, consulta a estabelecimentos comerciais do DF.

A caracterização química de amostra de lodo de esgoto da ETE - Norte analisada pela CAESB revelou $525 \mathrm{~g}$ kg-1 de matéria orgânica da matéria seca; pode-se assumir que no lodo fresco ou úmido, o conteúdo de M.O. será de 52,5 g kg-1 (dez vezes menor). Na cama de frango e no adubo do SLU, o conteúdo de matéria orgânica de ambos é $450 \mathrm{~g}$ kg-1 no material fresco; Os valores foram respectivamente de $R \$ 30.00$ e $R \$$ 13.00 por tonelada, independente do poder fertilizante deles.

O valor do lodo estimado pela matéria orgânica é menor do que o da cama de frango e do adubo do SLU. Entretanto, para aplicar no solo a mesma quantidade de matéria orgânica, será necessário transportar um volume nove vezes maior de lodo do que a das outras duas fontes, o que implica em custo nove vezes maior. E, ao analisar o custo do frete pago para o transporte do lodo de esgoto com conteúdo de água de $86 \%$, o produtor rural verificava quanto representaria, em custo, estes $14 \%$ de matéria seca adquirida em relação a outras fontes nestas mesmas quantidades.

Produtores entrevistados afirmaram que muitas vezes deixaram de adquirir o lodo de esgoto como insumo agrícola, por compensar, financeiramente, comprar outra fonte de matéria orgânica. A elevada quantidade de água existente no lodo fresco (86\%) é responsável pelo baixo valor dado à matéria orgânica.

A redução do teor de umidade do lodo de esgoto, obviamente, agregaria valor ao produto, e, consequentemente, reduziria os custos relativos do frete, tornando-se um produto mais atrativo para o agricultor.

\subsection{VALORAÇÃO CONTINGENTE}

\subsubsection{RESULTADO DA ENTREVISTA AO PRODUTOR RURAL}

Conforme dados da EMATER (2005), de um total de 13.496 produtores do DF, 58\% são produtores rurais patronais e $42 \%$ produtores rurais familiares. Como a EMATER-DF vem priorizando os seus trabalhos no processo de organização dos diversos segmentos e no acompanhamento das atividades produtivas gerou 
uma amostragem dos questionários respondidos por $55 \%$ de produtores rurais familiares e $45 \%$ de produtores rurais patronais. 0 nível geral de aceitação do lodo de esgoto por parte dos 410 produtores da região rural do DF foi de 68\%. Quando se questionou, até quanto o produtor estaria disposto a pagar (DAP) por um lodo de esgoto tratado e de melhor qualidade para ser utilizado na agricultura, obtiveramse cinco respostas distintas conforme mostra Tabela 01.

\begin{tabular}{|l|c|c|}
\hline \multicolumn{2}{|c|}{ Tabela 01 - Aceitação / rejeição } & $11 \%$ \\
\hline Não usaria & & $21 \%$ \\
\hline Não respondeu por falta de conhecimento & \multirow{2}{*}{$68 \%$} \\
\cline { 1 - 2 } Conhece o produto, usaria, mas não tem noção do preço. & $8 \%$ & $16 \%$ \\
\cline { 1 - 2 } Usaria, mas não está disposto a pagar. & $44 \%$ & \\
\hline Disposto a pagar & & $100 \%$ \\
\hline \multicolumn{2}{|c|}{ Total } & \\
\hline
\end{tabular}

Conforme resultado de pesquisa, que se baseou na valoração de contingente chegou-se à conclusão que o produtor rural do DF pagaria um valor médio de $\mathrm{R} \$ 18,62$ a tonelada do lodo de esgoto se fosse tratado e seco. Esses valores oscilaram de $\mathrm{R} \$ 1,00$ a $\mathrm{R} \$ 100,00$.

Este preço está em conformidade com outros trabalhos, como por exemplo, Fahy (1990), que, trabalhando com o mesmo método, mostrou que os preços de comercialização de lodos compostados nos Estados Unidos alcançariam valores de mercado de $\mathrm{R} \$ 23,00 / \mathrm{t}$ para horticultura.

0 nível de rejeição total do produto foi de apenas 11\% de modo que se obteve dos entrevistados que $21 \%$ mostraram total falta de conhecimento do uso do lodo de esgoto como adubação na agricultura e estes não se sentiram aptos a opinar quanto ao valor a ser pago por um produto que poderia ser de boa qualidade para ser utilizado na agricultura.

A falta de informação e conhecimento do produto está de acordo com Forste (1994), que para aumentar a confiabilidade do produtor deve-se desenvolver ações de treinamento quanto a utilização do lodo de esgoto, mostrando os benefícios e cuidados do insumo durante o manuseio.

Entre os produtores entrevistados, 33\% já utilizaram o lodo de esgoto em suas propriedades. Quanto ao conhecimento das normas e procedimentos para a expedição, distribuição e uso do lodo de esgoto, 35\% responderam que conheciam a norma em detrimento dos $65 \%$ que desconheciam uma norma de regulamentação.

O que mais o estimulou a fazer uso do produto foram tanto à viabilidade econômica (47\%) quanto a produtividade alcançada (44\%). Com efeito, como a produtividade alcançada está intimamente relacionada à viabilidade econômica, pode-se verificar que o produtor está muito mais preocupado com a sua rentabilidade econômica como fator preponderante nas suas atividades produtivas.

Segundo Lemainski (2003), o uso do lodo de esgoto apresentou vantagem comparativa ao uso dos fertilizantes minerais, com evidências positivas para doses de $30 \mathrm{t} / \mathrm{ha}$ e $45 \mathrm{t} / \mathrm{ha}$ em uma fazenda a $100 \mathrm{~km}$ da ETE Brasília Norte e alcançou o valor por tonelada do produto úmido de $\mathrm{R} \$ 22,98$ a $\mathrm{R} \$ 27,87$, respectivamente, considerando transporte, distribuição e incorporação. Silva et al. (2000) verificaram que, mantido o fornecimento gratuito, a aplicação do lodo de esgoto na dose de $54 \mathrm{t} / \mathrm{ha}$ em área até $100 \mathrm{~km}$ de distância da ETE geradora ocorre com vantagem de R\$ 74,00/ha sobre a aquisição de fertilizantes convencionais com $\mathrm{N}$ e $\mathrm{P}$ em quantidades equivalentes às contidas na dose recomendada de lodo.

Aos produtores rurais entrevistados foi perguntado quanto aos aspectos negativos na utilização do lodo de esgoto na agricultura e o principal fator de restrição foi o mau Cheiro (32\%), contaminação ambiental $(22,4 \%)$ e Doenças $(18 \%)$. A resposta do cheiro - odor como principal aspecto negativo ao uso do lodo de esgoto na agricultura assemelha-se com os trabalhos de outros autores. Andreoli et al. (1999) confirmaram que o mau cheiro incomodaria os produtores vizinhos e ao próprio produtor e Fernandes (2001) afirma que, o potencial de uso do lodo de esgoto está relacionado ao seu odor.

Ao perguntar sobre as doenças possíveis transmitidas pelo lodo de esgoto, ficou evidenciado pela falta de conhecimento do produtor rural quanto ao potencial de inoculo do produto, pois 68\% dos produtores rurais responderam que desconhecem este problema. Os 32\% que responderam ter conhecimento das doenças transmitidas pelo lodo de esgoto, ao serem questionados as quais eram do seu conhecimento, responderam basicamente de problemas intestinais, vermes e hepatite. 


\subsubsection{RESULTADO DA ENTREVISTA AO CONSUMIDOR}

Do total dos entrevistados, $52 \%$ dos consumidores responderam que procuram fazer compras de produtos hortifrutigranjeiros em estabelecimentos onde possam encontrar preço e qualidade. 0 nível total de aceitação do lodo de esgoto por parte dos 424 consumidores entrevistados da região urbana do DF foi de $43 \%$. Os resultados de pesquisa demonstram que os consumidores urbanos apresentaram resistência ao consumo de produtos adubados com lodo de esgoto.

Este resultado difere da pesquisa de Andreoli et al. (1999) que alcançaram 77\% de aceitabilidade dos 43 consumidores urbanos entrevistados da Feira Livre das Mercês, Feira Livre do Capanema, Feira Orgânica do Passeio Público e entre estudantes da graduação do curso de Engenharia Agronômica da Universidade Federal do Paraná - UFPR, região urbana de Curitiba.

0 questionário de pesquisa deste trabalho para o consumidor teve dois momentos distintos de aceitabilidade do consumo de produtos obtidos em solos adubados com lodo de esgoto. Primeiramente, após questionar o que é lodo de esgoto e se o entrevistado sabe se o lodo é utilizado na agricultura, pergunta-se se o consumidor adquiriria alimentos produzidos em solos adubados com lodo de esgoto. Houve apenas $18 \%$ de aceitabilidade por parte dos consumidores urbanos em detrimento de $82 \%$ de rejeição. Aos $82 \%$ dos entrevistados que rejeitaram inicialmente adquirirem produtos adubados com lodo de esgoto foi perguntado qual a razão desta rejeição. A principal resistência ao consumo de produtos produzido com lodo de esgoto como adubação foi tanto o nojo como a falta de informação do produto e suas consequências.

Houve um incremento na aceitabilidade de $139 \%$ quando o entrevistado recebeu um mínimo de informação sobre a utilização do lodo de esgoto na agricultura como sendo uma das melhores maneiras para se resolver o problema de sua destinação final e também que o lodo tratado seria um produto confiável (não provocaria nenhum tipo de doença) para ser utilizado como adubo.

Este resultado está de acordo com Andreoli et al. (1999) quando afirma que a garantia de qualidade do produto reverteria as opiniões positivas quanto à aceitabilidade dos produtos produzidos com lodo de esgoto na adubação.

Foi explicado aos entrevistados, que para se conseguir um lodo seguro e confiável para ser utilizado na agricultura e no meio ambiente, provavelmente haveria um aumento nos custos da conta de esgoto sanitário residencial. Então foi perguntado quanto o entrevistado estaria disposto a pagar a mais na sua conta de esgoto para que o lodo de esgoto se transformasse em um produto confiável e seguro. Obteve-se como resposta que $83 \%$ dos entrevistados não estariam dispostos a pagar nada, pois consideraram que este ônus deveria ser pago pelo produtor rural. A resposta da não disposição a pagar foi bastante coerente com o desconhecimento de quais os custos que estão embutidos numa conta de esgoto residencial. Os mesmos não acreditam que caso o lodo de esgoto fosse vendido como adubo e representasse uma receita para a concessionária que a sua conta de esgoto residencial diminuísse de valor a ser pago.

\section{CONCLUSÕES}

0 valor do custo de reposição dos elementos nitrogênio, fósforo, potássio e matéria orgânica presente em cada tonelada do lodo fresco foi calculado entre $\mathrm{R} \$ 25,36$ a $\mathrm{R} \$ 27,32$. Esta faixa de preço ocorreu por trabalhar com duas fontes de matéria orgânica, cama de frango e o adubo do "SLU".

A elevada quantidade de água existente no lodo fresco (86\%) é responsável pelo baixo valor dado à matéria orgânica. A redução do teor de umidade do lodo de esgoto agregaria valor ao produto o tornaria o produto mais atrativo para o produtor rural.

O produtor rural compara o preço do frete do lodo de esgoto com outras fontes de matéria orgânica existente no mercado e não com outras fontes de fertilizantes químicos.

A aceitabilidade geral por parte dos produtores rurais ao se fazer uso do lodo de esgoto como insumo agrícola foi de $68 \%$ enquanto que a aceitabilidade geral por parte dos consumidores urbanos a consumir alimentos produzidos com lodo de esgoto como insumo agrícola foi de $43 \%$.

O produtor rural do DF pagaria um valor médio de $\mathrm{R} \$ 18,62$ a tonelada do lodo de esgoto se fosse tratado e seco. $O$ aspecto positivo que mais influenciou o uso do lodo de esgoto pelos produtores rurais foi a sua viabilidade econômica e o principal aspecto negativo no uso do lodo de esgoto foi o seu odor. 
Nojo e a falta de informação do lodo de esgoto foram os principais fatores de rejeição por parte dos consumidores urbanos.

Os produtores rurais têm pouco conhecimento sanitário do uso e manuseio do lodo de esgoto na agricultura. Apenas $32 \%$ dos produtores responderam ter conhecimento das doenças transmitidas pelo lodo de esgoto. Houve um incremento de $139 \%$ de aceitabilidade do lodo de esgoto em relação aos que inicialmente haviam rejeitado quando o consumidor urbano recebeu informação sobre a utilização do lodo de esgoto na agricultura.

O consumidor urbano rejeita totalmente a ideia de se ter mais ônus na sua conta de esgoto residencial e não acredita que uma concessionária venha a diminuir o preço da conta caso esta tenha uma receita extra.

Este trabalho de pesquisa apresentou uma tendência de aumento da aceitabilidade dos consumidores urbanos na mesma direção ao aumento ao nível salarial, ao nível de escolaridade e ao nível da faixa etária. Para a gestão do uso do lodo de esgoto na reciclagem agrícola, sugere-se uma maior participação efetiva do produtor rural e do consumidor urbano nas diversas informações tecnológicas, riscos e potencialidades, de forma a dirimir todas as dúvidas, quanto ao uso do lodo de esgoto como insumo agrícola e permitir que os produtores rurais e os consumidores urbanos formem uma opinião fundamentada para se decidir quanto à sua aceitação ou rejeição.

\section{REFERÊNCIAS}

[1] Andreoli, C. V.; Bernet, P. M.; Favarin, F.; Ferreira, A. D. D. Aceitabilidade Pública da Utilização do Lodo de Esgoto na Agricultura da Região Metropolitana de Curitiba. SANARE. Revista Técnica da Sanepar. Curitiba, V.12 № 12 Julho a dezembro 1999.

[2] Bishop, R.C.; Heberlein, T. A. Measuring values of extra market goods: are indirect measured biased? American Journal of Agricultural Economics, v, 61, n.5, 1979. p. 926-930.

[3] Brugnaro, C. Valor atribuído pela população às matas ciliares da bacia do rio Corumbataí, SP. Piracicaba, 2000. 146 p. Tese (Doutorado) - Escola Superior de Agricultura “Luiz de Queiroz”, Universidade de São Paulo. 2000.

[4] Corrêa, R.S.; Corrêa, A S - Valoração de Biossólidos como fertilizantes e condicionadores de solos. In: Sanare Revista Técnica da Sanepar, Companhia de Saneamento do Paraná. Curitiba, 2001. p. 1-7.

[5] Emater-DF - Plano de Ação Local - Produção dos funcionários da Emater-DF. Brasília, DF. Emater - dez. 2005. 1 CD-ROM

[6] Fahy, P. C. Quality of sludge composts and their use in horticulture. In: The agriculture and horticulture use of sewage products. University of Western Australia : The Australian Institute of Agricultural Science, 1990. p. 3-5.

[7] Fernandes, F.; Andreoli, C. V.; Wigert, W.; Bonnet, B.R.P. Land application of sewage sludge: A programme for the state of Paraná. In: First International Exhibition of Environmental Technology - Environtech/95 e Third International Seminar on the Environmental Problems of Urban Centers - Ecourbs/95. Abstracts Volume pp. 66-67. Riocentro, Rio de Janeiro, Brazil, june 19-23, 2001.

[8] Forste, J. B. Gaining public acceptance for biossolids, in CLAPP, C. E. in al. Sewage sludge: land utilization and the environment. S.l.: Misc. Pu-blication, 1994. p. 81- 85.

[9] Lemainski, J. -Biossólido como fertilizante na agricultura do Distrito Federal. 2003. 115p. Dissertação (Mestrado em Ciências Agrárias) - Universidade de Brasília / Faculdade de Agronomia e Medicina Veterinária, Brasília, 2003.

[10] Pereira, J.; KAGE, H. Manejo da Matéria Orgânica em Solos do Cerrado In: Marquetti, D.; Machado, A. D.: Cerrado; Uso e Manejo. Editora Editerra, Brasília, DF, 1982. p. 579 - 595.

[11] Silva, J. E.; Resck, D.V.S.;Sharma,R.D. Alternativa Agronômica para o Biossólido. A experiência de Brasília. In: Bettiol, W; CAMARGO, O. A. Impacto ambiental do uso Agrícola do lodo de esgoto. Jaguariúna, SP: Embrapa Meio Ambiente, 2000. p. 143-151.

[12] Tsutiya, M.T; Comparini, J.B; Sobrinho, P. A; Hespanhol, I; Carvalho, P.C.T; Melfi, A.J; Melo, W.J; MARQUES, M.O; Biossólidos na Agricultura. 1ạ ed. São Paulo: SABESP, Jaboticabal. 2001. 468p. 


\section{Capítulo 16}

\section{A energia solar fotovoltaica no programa Minha Casa Minha Vida}

\section{Dione Vitor dos Santos}

Resumo: Atualmente, o Brasil enfrenta dois grandes desafios socioambientais. 0 primeiro está relacionado ao setor de segurança energética, e o segundo diz respeito ao déficit habitacional. Embora o setor energético suscite a busca pelo aumento da participação de energias limpas e renováveis na matriz energética brasileira, ainda são parcas as ações que atrelem essa necessidade a trabalhos pontuais para as grandes massas populacionais com baixa renda. 0 segundo desafio é o déficit habitacional, que ocasiona o crescimento desordenado das cidades pela falta de planejamento urbano, moradias precárias sem saneamento básico e ocupação irregular do solo - aspectos que contribuem à degradação do meio ambiente e das relações sociais. Este estudo analisou a viabilidade da microgeração de energia fotovoltaica para uso residencial, no contexto do Programa Minha Casa Minha Vida / Programa Morar Bem do Distrito Federal, fazendo uso da coleta de dados primários dos moradores do Conjunto Habitacional do Paranoá Parque, empreendimento destinado às famílias de renda mensal de até $\mathrm{R} \$ 1.600,00$. Os dados foram obtidos com visitas in loco para aplicação de questionários e entrevistas; de análise de documentos do Programa de habitação e da Agência Nacional de Energia Elétrica (Aneel). Utilizando análise dos dados quali-quantitativa da posse e uso dos eletrodomésticos de cada apartamento, da média anual do consumo e do custo da energia dos moradores, foi possível cotar com empresas fornecedoras de sistemas fotovoltaicos completos o custo e o retorno do investimento gasto na microgeração de energia em condomínios de baixa renda. Este estudo identificou que a microgeração fotovoltaica somente é viável se os Programas a incluírem nos itens com direito a subsídios financeiros. 0 investimento inicial é elevadíssimo às famílias, especialmente às de baixa renda, ressalta-se que 31\% dos moradores evitam o uso de chuveiro elétrico devido ao alto consumo de energia. Desta forma, identificaram-se oportunidades de melhoria no Programa Minha Casa Minha Vida / Morar Bem: as casas e apartamentos poderiam ser construídos com sistemas solares de aquecimento d'água e microgeração de energia elétrica fotovoltaica. Os Programas MCMV/MB ofereceriam incremento da qualidade de vida sem custo ambiental causado pela construção de usinas hidroelétricas ou termoelétricas.

Palavras-Chave: energia fotovoltaica, baixa renda, impacto socioambiental 


\section{INTRODUÇÃO}

A segurança energética tornou-se uma preocupação atual da sociedade e dos governos, devido a crescente escassez dos combustíveis fósseis e aos grandes impactos ambientais causados pela intensificação da exploração da natureza, com vistas a suprir o aumento da demanda por consumo de energia. Projeções da Agência Internacional de Energia preveem um crescimento de 45\% no consumo de energia mundial para 2030, (IEA,2016).

Diante desse quadro, cresce o interesse das grandes cidades e municípios por fontes energéticas renováveis, ou seja, fontes de energia geradas por meio de tecnologias limpas, com destaque para a energia solar. No Brasil, país de clima tropical, o sol é uma fonte abundante com uma incidência constante durante o ano todo. Assim, a integração da energia solar à matriz energética seria um grande avanço na busca para a segurança energética.

Um outro desafio é o déficit habitacional um agravante que tem influenciado o crescimento desordenado das cidades e municípios pela falta de planejamento urbano, moradias sem saneamento básico e ocupação irregular do solo são aspectos que contribuem para a degradação do meio ambiente e das relações sociais. O planejamento para construções de moradias com acoplamento de sistemas para uso de energia solar e uso sustentável da água são ações consideradas ambientalmente correta que estão relacionadas com uma das metas, que o Governo Brasileiro estipulou na área ambiental, justamente dobrar a participação de energia renováveis na matriz energética (como a luz solar), práticas que fazem parte dos chamados Objetivo de Desenvolvimento Sustentável (ODS), ações da "Agenda-2030 para o Desenvolvimento Sustentável"1.

Este artigo teve como ponto de partida a caracterização da tecnologia de energia solar fotovoltaica e objetivou a microgeração de energia e o seu potencial de contribuir com o crescimento econômico da população de baixa renda, com a mitigação dos problemas ambientais e com a inclusão social.

0 estudo analisou a viabilidade econômica da instalação de sistema de microgeração fotovoltaico residencial no contexto do Programa Minha Casa Minha Vida- (PMCMV) ${ }^{2}$ do Governo Federal, vinculado ao Programa Morar Bem ${ }^{3}$ do Distrito Federal.

0 gasto financeiro com energia elétrica é um dos grandes problemas para as famílias de baixa renda, pois mesmo com o benefício da tarifa social ${ }^{4}$, o uso de eletrodomésticos como chuveiro elétrico e ferro de passar roupa demandam muita energia elétrica. Desta forma, considera-se a geração de energia solar seria uma alternativa viável para implantação dessa fonte energética renovável em residências beneficiadas pelo PMCMV, sendo uma das formas de diminuir o custo com o gasto de energia elétrica e assim assegurar energia sustentável por meio de ações que possibilitem a eficiência energética e qualidade de vida.

\section{SISTEMAS SOLARES FOTOVOLTAICOS}

O Sol é a principal fonte de energia que pode ser convertida em energia elétrica por sistemas de células fotovoltaicas ${ }^{5}$. No entanto, apesar da fonte de energia solar ser considerada limpa e abundante, um dos grandes desafios para o uso dessa fonte é o elevado custo para a implantação da tecnologia. As principais vantagens do uso energia solar fotovoltaica são: a matéria prima é inesgotável; não há emissão de poluentes durante a geração da eletricidade; e os sistemas podem ser instalados em qualquer ponto do país.

As tecnologias para produção e implantação do sistema solar ainda não está economicamente acessível, mesmo assim, o interesse na utilização dos sistemas de energia solar tem aumentado, tendo em vista a

\footnotetext{
1 Agenda-2030 é um plano de ação para as pessoas, para o planeta e para a prosperidade. Disponível em $<$ https://nacoesunidas.org/pos2015/agenda2030/> Acesso em 29/10/2016

20 Programa MCMV foi incialmente instituído pela MP 459, de 25/03/2009, substituída pela Lei11.977, de 07/07/2009, e regulamentado pelos Decretos 6819, de 13/04/2009 e 6962, de 19/09/2009.

3 O Programa Morar Bem do Distrito Federal, atualmente foi substituído pelo (Habita Brasília). No entanto, este estudo concentra-se apenas no período do Programa Morar Bem do DF, iniciado em 2011.

${ }^{4}$ A Tarifa Social e Energia Elétrica é um benefício instituído pela Lei Federal 10.438/02 para atender às famílias enquadradas na subclasse residencial baixa renda, caracterizada por descontos incidentes sobre a tarifa aplicável à classe residencial. (Disponível em: <http://www.planalto.gov.br/ccivil_03/leis/2002/L10438.htm>. Acesso em $19 / 08 / 2016$

5 Uma célula fotovoltaica é uma unidade básica de um sistema fotovoltaico. É a responsável pela conversão da radiação solar em eletricidade Blue Sol, energia solar. Disponível em <http://www.blue-sol.com.br> Acesso em: $19 / 08 / 2016$.
} 
possibilidade de uma real economia nos gastos de energia elétrica. Os sistemas de microgeração de energia solar podem ser instalados em residências domésticas, autônomos e conectados à rede, por exemplo: os sistemas fotovoltaicos autônomos ou remotos - necessitam quase sempre de um meio de acumulação de energia gerada, normalmente um banco de baterias ${ }^{6}$, para suprir a demanda em períodos quando a geração solar é insuficiente à noite; e os sistemas conectados à rede (on grid) ${ }^{7}$, que são sistemas solares fotovoltaicos que vêm sendo utilizados de forma interligada à rede elétrica pública, como usinas geradoras em paralelo às grandes centrais geradoras elétricas convencionais. Todo potencial gerado de energia solar fotovoltaica é escoado para a rede elétrica de distribuição e essa conexão está condicionada a regulamentação da Agência Nacional de Energia Elétrica - (ANEEL).

A ANEEL publicou em 24 de novembro de 2015, a Resolução Normativa № 687, que traz os Procedimentos de Distribuição de Energia Elétrica no Sistema Elétrico Nacional (PRODIST), para regular o acesso de micro e mini-geradores ao sistema de distribuição pública.

Os sistemas on-grid dependem da regulamentação e legislação favorável, pois usam a rede de distribuição da concessionária para o escoamento da energia gerada. No Distrito Federal, a concessionária responsável pelo fornecimento de energia elétrica é a Companhia de Energética de Brasília (CEB). A Resolução

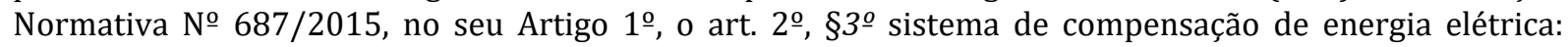
sistema no qual a energia ativa injetada por unidade consumidora com microgeração ou mini-geração distribuída é cedida, por meio de empréstimo gratuito, à distribuidora local e posteriormente compensada com o consumo de energia elétrica ativa.

\section{PROGRAMA HABITACIONAL “MINHA CASA, MINHA VIDA E PROGRAMA MORAR BEM DO DISTRITO FEDERAL}

O Brasil possui uma extrema desigualdade social que se prolonga desde o período de sua colonização. A Constituição Federal de 1988 assegura que habitação adequada é uma necessidade básica para o ser humano. No entanto, a importância sobre o tema que trata da urbanização, favelas e loteamento irregulares entraram definitivamente na agenda política habitacional em 2001, quando foi criado o Estatuto da Cidade com o objetivo de implementar uma política de desenvolvimento urbano, como a política de subsídio à habitação popular. Em 2003 com a criação do Ministério da Cidade a política habitacional foi fortalecida com a implementação do Plano Nacional de Habitação (PlanHab) é uma das ferramentas para garantir a PNH. Ele traça estratégias de curto e longo prazo até 2023 e uma das suas principais ações é o programa Minha Casa, Minha Vida, criado em 2009 pelo governo federal.

O Programa Minha Casa Minha Vida, é uma das ações do Programa de Aceleração do Crescimento (PAC) ${ }^{8}$ criado pelo Governo Federal para alavancar os eixos de infraestrutura logística energética e social urbana do Brasil. Lançado em 2009, o programa MCMV é um programa social de política habitacional tem como objetivo facilitar o acesso à casa própria para famílias de baixa renda que vivem nas grandes cidades ou no meio rural ${ }^{9} \mathrm{e}$ assim melhorar a qualidade de vida da população caracterizada de baixa renda.

O Programa Morar Bem ${ }^{10}$, vinculado ao Programa Minha Casa Minha Vida do Governo Federal, foi criado em 2011 visando a construção de unidades habitacionais no Distrito Federal. A proposta é ofertar moradias com infraestrutura urbana, como abastecimento de água, esgoto sanitário, energia elétrica, iluminação pública, instalações telefônicas, redes de drenagem de águas pluviais, pavimentação asfáltica e equipamentos públicos como escolas, postos de saúde e de polícia. A gestão do Programa Morar Bem é coordenada pela Companhia de Desenvolvimento Habitacional do Distrito Federal (CODHAB-DF). 0 processo de habilitação é realizado pela Caixa Econômica Federal mediante análise de regularidade institucional e qualificação técnica (CAIXA, 2011).

\footnotetext{
${ }^{6}$ Banco de baterias para suprir a demanda em períodos quando a geração solar é insuficiente à noite (Ruther,2004).

7 Os sistemas conectados à rede, também chamados de on-grid, geralmente não utilizam sistemas de armazenamento de energia, e por isso são mais eficientes que os sistemas autônomos, além de, geralmente, serem mais baratos, (Blue Sol, 2015).

8 Programa Minha casa, Minha Vida, dezembro de 2015, foram contratadas 4,16 milhões de moradias em 96\% dos municípios brasileiros e entregues 2,5 milhões de unidades habitacionais (UH), beneficiando cerca de nove milhões de pessoas. Disponível em: <http://www.pac.gov.br/sobre-o pac/publicacoesnacionais> em: 28/05/2016

9 Minha Casa Minha Vida Rural, voltado para agricultores familiares, trabalhadores rurais ou de comunidades tradicionais (como quilombolas, extrativistas, pescadores artesanais, ribeirinhos e indígenas. 0 atendimento permite tanto a construção de novas casas quanto a reforma de unidade já existente.

${ }^{10}$ As condições para participar do Programa Mora Bem estão previstas na Lei 3.877/2006, que dispõe sobre a Política Habitacional do Distrito Federal.
} 
O Programa Morar Bem do DF, assim como o Minha Casa Minha Vida do Governo Federal também possui faixas de classificação de renda familiar mensal que são as seguintes: (Faixa I: 0 a $R \$ 1.600,00$ ); (Faixa II: R\$ 1.600,01 a R\$ 3.275,00); (Faixa III: R\$ 3.275,01 a R\$ 5.000,00); (Faixa IV: R\$5.000,00 até 12 salários mínimos), (Portal da CODHAB,2016). Assim, foram consideradas para o estudo a "Faixa I", beneficiada pelo o PMCMV, e o "Conjunto Habitacional Paranoá Parque", único empreendimento destinado às famílias de baixa renda vinculado ao programa, que atende o propósito do estudo. As outras Faixas 2, 3 e 4 estão vinculadas ao PPP (parceria pública e privada).

\section{CONJUNTO HABITACIONAL PARANOÁ PARQUE: LOCALIZAÇÃO}

O Conjunto Habitacional de interesse social está situado ao lado da Cidade do Paranoá, localizado na entrada da cidade conhecida como Pinheiral. O conjunto é composto por vinte e seis condomínios, cada um possuindo uma área de $1.225 \mathrm{~m}^{2}$ com 15 blocos, um castelo (caixa d'água), um centro comunitário, 253 vagas de garagem, sendo as mesmas de uso comum do condomínio, totalizando 240 unidades autônomas. Cada bloco residencial possui 04 pavimentos (Térreo, $1^{\circ}$, 2ํ e $3^{\circ}$ pavimentos), cada pavimento é composto de 04 apartamentos, com o total de 16 apartamentos em cada bloco. Ao todo o conjunto habitacional possui 390 prédios com o total de 6.240 apartamentos.

Planta das Torres: o bloco possui o formato $\mathrm{H}$; telhado de fibrocimento com $174 \mathrm{~m}^{2}$, com corte de 2 águas e inclinação de 10\%, com platibanda com calha para água pluvial. Planta do apartamento: 2 quartos, circulação, banheiro, sala de estar e jantar conjugadas, cozinha de área de serviços conjugadas, com o total de 5 cômodos, metragem: 46,22 $\mathrm{m}^{2}$, (CODHAB,2016). A Figura 1- apresenta o Mapa de Localização do Condomínio e a planta estruturada.

Figura 1: Mapa de localização do Conjunto Habitacional Paranoá Parque

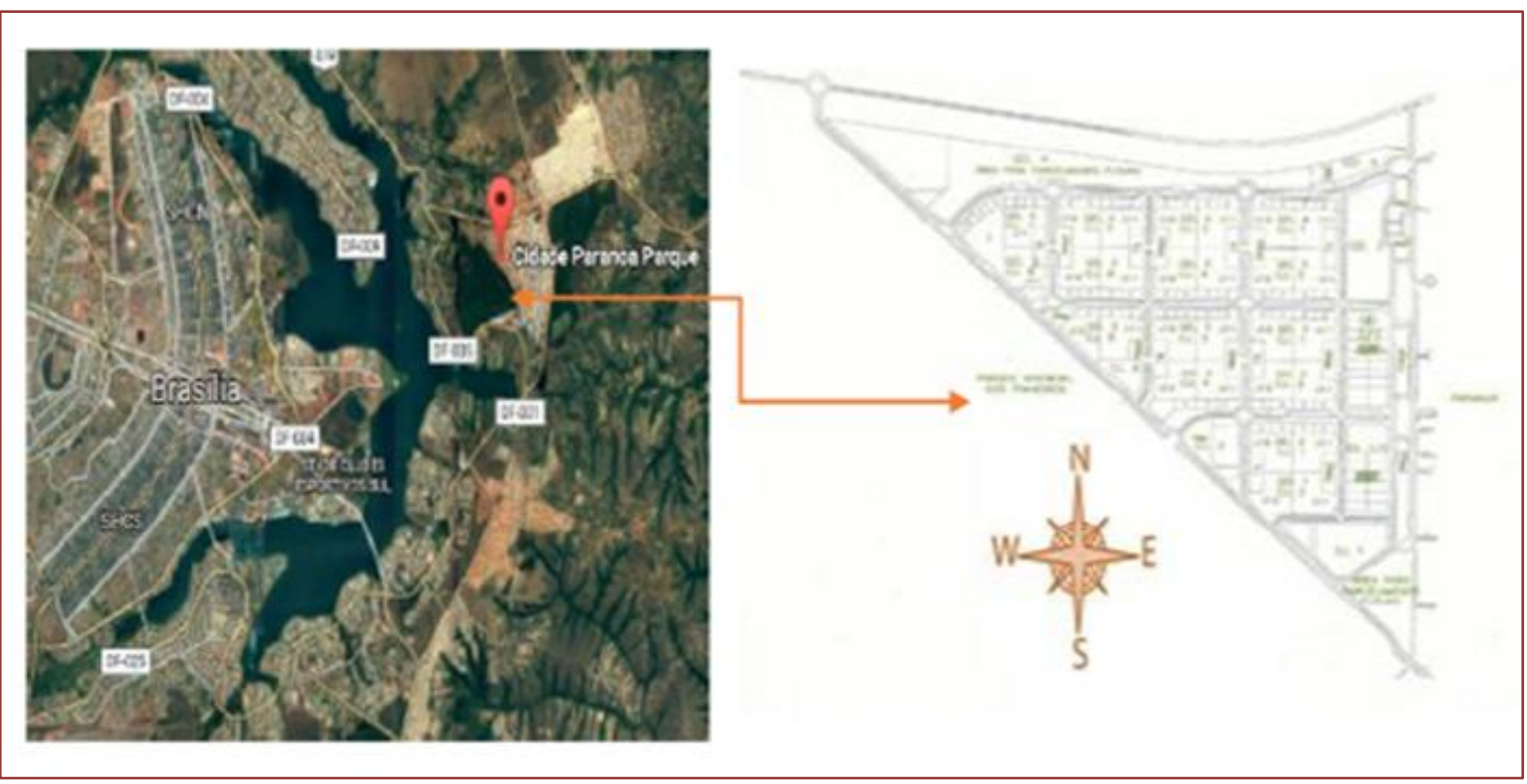

Fonte: Google Maps 
IMAGENS 1 - Conjunto Habitacional Paranoá Parque

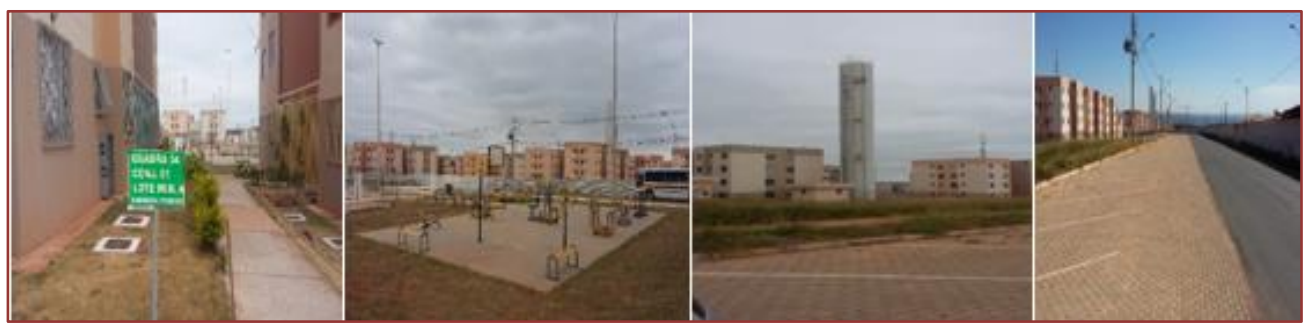

Fonte: (imagens fotografas pela autora em 26 de junho 2016)

Para solicitação dos orçamentos a empresas fornecedoras de painel fotovoltaico foi necessário fazer um levantamento de dados, como local de instalação referente ao Conjunto Habitacional do Paranoá Parque: Localidade: Brasília-DF; Latitude: -015-46'-03"; Longitude: -047--47-11"; Altitude: 1.159m; Albedo: (taxa de reflexão da radiação solar): 29\% (grama seca, asfalto), (Atlas Solamérico Brasileiro, 2016).

\section{METODOLOGIA}

O estudo foi realizado com visitas in loco para entrevistar os 16 moradores de um Condomínio. 0 objetivo foi realizar o censo dos eletrodomésticos, identificar os hábitos de seus usos e o consumo de energia elétrica, principalmente, a média de consumo anual de energia elétrica e seu custo. Para averiguação da quantidade de eletrodomésticos foi confeccionado um questionário baseado na tabela de consumo em kWh de eletrodoméstico domiciliar da Procel, CEB e COPEL. A Tabela (1) apresenta o censo dos eletrodomésticos dos moradores costumam usar no cotidiano domiciliar.

Tabela 1: Censo dos eletrodomésticos dos moradores do conjunto Habitacional Paranoá Parque

\begin{tabular}{|c|c|c|c|c|c|c|c|c|}
\hline \multicolumn{9}{|c|}{ CENSO DE ELETRODOMÉSTICOS } \\
\hline & \multicolumn{2}{|c|}{ Sim } & \multicolumn{2}{|c|}{ Mão } & \multicolumn{2}{|c|}{ Total } & \\
\hline & H & $\%$ cit. & H & $\%$ cit. & II & $\%$ cit. & & \\
\hline Chuveiro_elétrico & 11 & $68,8 \%$ & 5 & $31,3 \%$ & 16 & $100,0 \%$ & & $100,0 \%$ \\
\hline Geladeira & 16 & $100,0 \%$ & 0 & $0,0 \%$ & 16 & $100,0 \%$ & 1000 & $100,0 \%$ \\
\hline Ferro_passar & 13 & $81,3 \%$ & 3 & $18,8 \%$ & 16 & $100,0 \%$ & 28,3 & $100,0 \%$ \\
\hline Forno_elétrico & 7 & $43,8 \%$ & 9 & $56,3 \%$ & 16 & $100,0 \%$ & $43,0 x \sqrt{5,030}$ & $100,0 \%$ \\
\hline Microondas & 9 & $56,3 \%$ & 7 & $43,8 \%$ & 16 & $100,0 \%$ & 50,36 (स, 06 & $100,0 \%$ \\
\hline Liquidificador & 14 & $87,5 \%$ & 2 & $12,5 \%$ & 16 & $100,0 \%$ & 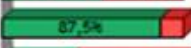 & $100,0 \%$ \\
\hline Batedeira & 6 & $37,5 \%$ & 10 & $62,5 \%$ & 16 & $100,0 \%$ & $\begin{array}{lll}3,5,5,56 \\
\end{array}$ & $100,0 \%$ \\
\hline Sanduicheira & 9 & $56,3 \%$ & 7 & $43,8 \%$ & 16 & $100,0 \%$ & \begin{tabular}{|l|l|l|}
50,30 & 43,00 \\
\end{tabular} & $100,0 \%$ \\
\hline Lavadora_roupa & 15 & $93,8 \%$ & 1 & $6,3 \%$ & 16 & $100,0 \%$ & $3200 \quad 1$ & $100,0 \%$ \\
\hline Ventilador & 9 & $56,3 \%$ & 7 & $43,8 \%$ & 16 & $100,0 \%$ & \begin{tabular}{|l|l|l|}
50,36 & 43,56 \\
\end{tabular} & $100,0 \%$ \\
\hline Làmpada_incandescente & 2 & $12,5 \%$ & 14 & $87,5 \%$ & 16 & $100,0 \%$ & 906 & $100,0 \%$ \\
\hline Lâmpada_fluorescente & 16 & $100,0 \%$ & 0 & $0,0 \%$ & 16 & $100,0 \%$ & 1000 & $100,0 \%$ \\
\hline Aparelho_som & 6 & $37,5 \%$ & 10 & $62,5 \%$ & 16 & $100,0 \%$ & 3,5: 025,5 & $100,0 \%$ \\
\hline TV_tubo & 3 & $18,8 \%$ & 13 & $81,3 \%$ & 16 & $100,0 \%$ & 181,36 & $100,0 \%$ \\
\hline TV_plana & 12 & $75,0 \%$ & 4 & $25,0 \%$ & 16 & $100,0 \%$ & 20 & $100,0 \%$ \\
\hline DVD & 11 & $68,8 \%$ & 5 & $31,3 \%$ & 16 & $100,0 \%$ & 20,06 उ1, & $100,0 \%$ \\
\hline Microcomputador & 3 & $18,8 \%$ & 13 & $81,3 \%$ & 16 & $100,0 \%$ & 181,20 & $100,0 \%$ \\
\hline Secador_cabelos & 6 & $37,5 \%$ & 10 & $62,5 \%$ & 16 & $100,0 \%$ & 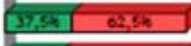 & $100,0 \%$ \\
\hline Chapinha & 5 & $31,3 \%$ & 11 & $68,8 \%$ & 16 & $100,0 \%$ & $31,361 \quad 60,06$ & $100,0 \%$ \\
\hline
\end{tabular}

Fonte: Compilação de dados do levantamento de eletrodomésticos dos moradores do conjunto Habitacional Paranoá Parque realizado no âmbito do estudo

Para complementação ao levantamento de dados da pesquisa, foi solicitado aos 16 moradores de baixa renda que estão cadastrados no programa de tarifa social da CEB, a fatura de energia elétrica domiciliar com o objetivo de averiguar a média anual do consumo de energia e kWh. Além disso, foi avaliada a média do histórico de consumo mensal das contas de energia elétrica de cada apartamento, também foi incluído o consumo de energia do Centro Comunitário e o Castelo D'Água conforme apresentado na Tabela 2. 
TABELA 2 - Histórico de Consumo de Energia Elétrica dos Moradores de um Condomínio do Conjunto Habitacional Paranoá Parque, por unidade residencial

\begin{tabular}{|c|c|c|c|c|c|}
\hline \multirow[t]{2}{*}{ *Aptos. } & \multicolumn{2}{|c|}{ Conta de Energia Elétrica de Maio 2016} & \multicolumn{3}{|c|}{$\begin{array}{l}\text { Histórico de Consumo de Energia } \\
\text { Elétrica }\end{array}$} \\
\hline & Consumo (kWh) & Total a Pagar & Mês & (kWh) & Média Anual \\
\hline 1 & 102 & 38,03 & NOV & 176 & 113 \\
\hline 2 & 206 & 99,11 & $\mathrm{ABR}$ & 224 & 212 \\
\hline 3 & 116 & 45,30 & NOV & 147 & 121 \\
\hline 4 & 188 & 88,77 & NOV & 203 & 177 \\
\hline 5 & 195 & 116,48 & NOV' & 216 & 194 \\
\hline 6 & 104 & 38,97 & AGO & 156 & 124 \\
\hline 7 & 129 & 50,78 & NOV & 144 & 121 \\
\hline 8 & 146 & 169,15 & AGO & 212 & 177 \\
\hline 9 & 135 & 53,62 & JAN & 229 & 149 \\
\hline 10 & 68 & 19,4 & $\mathrm{ABR}$ & 66 & 61 \\
\hline 11 & 102 & 64,86 & JUL & 120 & 90 \\
\hline 12 & 114 & 36,75 & MAR & 149 & 96 \\
\hline 13 & 64 & 33,56 & DEZ & 82 & 57 \\
\hline 14 & 88 & 26,12 & JAN & 100 & 84 \\
\hline 15 & 159 & 64,95 & NOV & 198 & 160 \\
\hline 16 & 135 & 55,53 & MAI & 160 & 137 \\
\hline Caixa da Água & 391 & 250,00 & JAN & 371 & 371 \\
\hline Centro Comunitário & 36 & 55,00 & JUL & 90 & 36 \\
\hline Total & 2.478 & $\mathrm{R} \$ 1.306,38$ & & 3.043 & 2.480 \\
\hline
\end{tabular}

Fonte: Compilação de dados do levantamento da fatura de conta de luz dos moradores do Conjunto do Paranoá Parque realizado no âmbito do estudo.

A Tabela 2, apresenta o Histórico do Consumo de Energia Elétrica, com o consumo médio anual das 16 unidades residenciais, sua Caixa D'água e o Centro Comunitário. Com a média anual: $2.480 \mathrm{kWh} x$ $\mathrm{R} \$ 0,5271 \mathrm{kWh}=\mathrm{R} \$ 1.307,43$, obtém-se a informação necessária ao cálculo do retorno do investimento (quanto se gasta por mês na média para pagar as contas de energia elétrica e que será economizado para se pagar o sistema fotovoltaico). Solicitou-se às empresas fornecedoras do sistema fotovoltaico o orçamento, com as seguintes informações: (i) área do telhado disponível à instalação dos painéis fotovoltaicos necessários para gerar a energia elétrica consumida pelas famílias; (ii) consumo médio de energia elétrica anual em kWh; (iii) localização do condomínio; e (iv) tensão da energia elétrica consumida pelos moradores baixa renda (monofásico/trifásica). Na Tabela 3, apresenta-se a comparação dos orçamentos de três empresas fornecedoras de sistemas fotovoltaicos.

TABELA 3 - Comparativa do Orçamento das Empresas de Painéis Solares

\begin{tabular}{|c|c|c|c|}
\hline Orçamentos & Empresa A & Empresa B & Empresa C \\
\hline Premissas de Geração & \multicolumn{3}{|c|}{ atender ao consumo médio mensal de $2.450 \mathrm{kWh} /$ mês } \\
\hline Potência de Pico do Sistema & $18 \mathrm{KWp}$ & $20 \mathrm{KWp}$ & $18 \mathrm{KWp}$ \\
\hline № Painéis (Módulos) & 58 & 77 & 68 \\
\hline Modelo dos Painéis & Trina Solar TS 310 & Yingli & $\begin{array}{c}\text { All-Black CS6P- } \\
265 \mathrm{M} \\
\end{array}$ \\
\hline Área Ocupada & $135 \mathrm{~m} 2$ & $177 \mathrm{~m} 2$ & $109,5 \mathrm{~m} 2$ \\
\hline Geração de Energia Elétrica do Sistema kWh/mês & 2.393 & 2.450 & 2.393 \\
\hline Porcentual da Média Mensal de 2.480 kWh & $96,50 \%$ & $100,00 \%$ & $96,50 \%$ \\
\hline Economia Estimada por Ano & $\mathrm{R} \$ 15.140,00$ & $\mathrm{R} \$ 22.000,00$ & não informado \\
\hline Retorno do Investimento (Payback) & 7 anos & 6 anos & 7 anos \\
\hline Garantia do Inversor contra Defeitos de Fabricação & & 5 anos & \\
\hline Conta de Energia Elétrica Protegida contra Inflação & & Sim & \\
\hline Valorização do Imóvel & & Sim & \\
\hline Baixo Impacto Ambiental Energia Renovável de Fonte Limpa & & Sim & \\
\hline \multicolumn{4}{|c|}{ Formas de Pagamento } \\
\hline EMPRESA (A) & \multicolumn{3}{|c|}{ 15\% Sinal + 9 X sem juros } \\
\hline EMPRESA (B) & \multicolumn{3}{|c|}{$30 \%$ Sinal $+4 \times$ sem juros } \\
\hline EMPRESA (C) & \multicolumn{3}{|c|}{$30 \%$ Sinal + 4 X sem juros } \\
\hline Empresas: (A); (B); (C); & \multicolumn{3}{|c|}{ Ou financiamento Stander em até $60 \mathrm{x}$ à $1,95 \% \mathrm{am}$. } \\
\hline
\end{tabular}


Objetivos e Escopo da Proposta: Prestar serviços de: (1) Fornecimento do sistema de geração de energia elétrica; (2) Elaboração de Projeto de Engenharia; (3) Instalação do sistema de geração fotovoltaica; e (4) Assessoria para obtenção de autorização da empresa distribuidora - CEB para conexão do sistema de geração à rede de distribuição.

A Tabela 3, apresenta a viabilidade econômico-financeira para implantação do sistema de energia elétrica fotovoltaica: investimento necessário para a instalação do sistema para atender ao consumo das 16 famílias; e a estimativa do tempo de retorno do investimento no contexto do PMCMV. Os cálculos apresentados são referentes ao Valor Presente Líquido (VPL); Taxa Interna de Retorno (TIR) e Payback (tempo de retorno sobre o investimento). Tipo de fonte de energia: painéis solares; tecnologia e tipo de equipamentos de geração; porte da unidade consumidora e da central geradora a ser instalada (potência instalada tanto da carga quanto da geração); localização (rural/urbana); tarifa de energia à qual a unidade consumidora está submetida (monofásica/trifásica); condições de financiamento e pagamento de cada projeto; se existem outras unidades consumidoras que poderão usufruir dos créditos do sistema de compensação de energia elétrica.

Da Tabela 3, destacamos que o gasto financeiro com a fatura de energia elétrica, atualmente, é da ordem de $\mathrm{R} \$ 1.307,43$. E, para a implantação do sistema fotovoltaico os moradores teriam que desembolsar somente de juros por mês a quantia de $\mathrm{R} \$ 2.379,00$ ( $\mathrm{R} \$ 122.000,00$ x 1,95\% a.m.), valor $82 \%$ acima ao gasto mensal de consumo de energia elétrica da CEB.

\section{CONCLUSÃO}

O presente estudo indicou inviabilidade econômica e financeira para implantação do sistema fotovoltaico on grid no Conjunto Habitacional Paranoá Parque do DF (Faixa 1). Como principais pontos destacam-se: (1) implantação do sistema solar fotovoltaico, somente será viável se houver subsídios e ou financiamento com juros baixos do governo e ou organismos institucionais; (2) o Programa Minha Casa Minha Vida (PMCMV) vinculado a ações de eficiência energética, evita a ocupação desordenada do solo e promove o uso racional de recursos de fontes renováveis, uma forma de minimizar o impacto ambiental causado pela exploração de recursos não renováveis para suprimento de energia.

Como recomendações, sugere-se a implantação de sistemas com energia solar por meio de programas e ações de "eficiência energética" do governo, tendo em vista que dos moradores do PMCMV/ Programa Morar Bem DF (PMBDF) (Faixa 1), 31\% dos entrevistados evitam o uso do chuveiro elétrico por não conseguirem pagar a conta de luz por falta de condições econômicas e assim, não fazem uso da energia elétrica em sua plenitude.

Desta forma, identificou-se uma oportunidade de melhoria no Programa Minha Casa Minha Vida / Morar Bem com a implantação de sistemas solares de aquecimento d'água e microgeração de energia elétrica fotovoltaica integrados às construções de casas e apartamentos. Os programas ofereceriam assim, incremento da qualidade de vida sem o custo ambiental causado pela construção de usinas hidroelétricas ou termoelétricas.

Neste estudo, não foram abordados diretamente, cenários de possíveis incentivos ao uso de energia fotovoltaica em residência com a população de baixa renda. No entanto, no Programa de Eficiência Energética (EE) promovido pela Companhia Energética de Brasília (CEB), existem recursos destinados a população de baixa renda que contemplam projetos para implantação de painéis solares destinados ao aquecimento de água. O Programa EE da CEB ainda não contempla projetos para moradores em edificações residenciais de baixa renda.

Considerando ainda o Programa de Eficiência Energética da CEB, regulamentado pela Agência Nacional de Energia Elétrica (ANEEL), tanto a CEB como Governo do Distrito Federal (GDF) poderiam ser proativos com relação aos incentivos à utilização de energia renováveis. 


\section{BIBLIOGRAGIA:}

[1] Aneel. Agência Nacional de Energia Elétrica. Resolução Normativa n.482, de 24 de novembro de 2015. Altera a Resolução 482, de 17 de abril de 2012, e os Módulos I e 3 dos Procedimentos de Distribuição - PRODIST. Disponível em: <www.aneel.gov.br/cedoc/ren2015687.pdf. > Acesso em: 19/05/2015.

[2] Brasil, Governo Federal, Programa Minha Casa Minha Vida. Disponível <http://www.programadogoverno.org/programa-minha-casa-minha-vida/> Acesso em 10 abr. 2016.

[3] Blue Sol. Energia Solar. Disponível em:<http://bluesol.com.br/> Acesso em 13/05/2016

[4] Ceb. Companhia Energética de Brasília. Programa de Eficiência Energética Disponível em: http://www.ceb.com.br/ Acesso em: 30/05/2016

[5] Codhab-DF. Companhia de Desenvolvimento Habitacional do Distrito Federal. Programa Morar Bem Distrito Federal. Disponível em <http://www.codhab.df.gov.br/pagina/1> Acesso em: abr. 2016.

[6] Copel. Companhia Paranaense de Energia. Disponível em< http://www.copel.com/> Acesso em: 05/05/2016

[7] Ecovolts. Energia Solar Gerando Eletricidade. Disponível em <http://www.ecovolts.net.br/> Acesso em $10 / 05 / 2016$.

[8] IEA.Internaional Energy Agency. Disponível em < https://www.iea.org/countries/> Acesso em 01/06/2016

[9] Gil, Antônio Carlos. Métodos e técnicas de pesquisa social. 6a edição. São Paulo: Editora Atlas, 2008.

[10] Marconi, Marina de Andrade; Lakatos, Eva Maria. Fundamentos de metodologia científica.7ª edição São Paulo: Editora Atlas,2010.

[11] Mma. Ministério do Meio Ambiente. Disponível em:<http://mma.gov.br/> Acesso em:20/04/2016

[12] Ministério das Cidades: Política Nacional de Habitação, caderno 4, 2004.Disponível em: s http://www.cidades.gov.br. > Acesso em: 20 de mai.2016

[13] Ministério do Planejamento: Programa de Aceleramento do Crescimento- (PAC). Disponível em: < http://www.pac.gov.br/sobre-o-pac/publicacoesnacionais>Acesso em: 28/05/2016.

[14] Rennove. Engenharia. Disponível em: < http://www.rennoveengenharia.com.br/ > Acesso em: 06/05/2016.

[15] Ruther, Ricardo. Edifícios solares fotovoltaicos. Florianópolis; Editora UFSC,2004.

[16] Ufpe. Universidade Federal de Pernambuco. Atlas Solamérico do Brasil: banco de dados solamérico. 111p.: 2. ed. Recife. UFPE,2000. 


\section{Capítulo 17}

\section{Custos de implantação de uma horta caseira}

\section{Ranieri Queiroz da Costa \\ Ríssia Ribeiro da Silva \\ Maíra Anunciação Brito de Oliveira \\ Silvia Elaine Moreira}

Resumo: A presente pesquisa discorre sobre o custo de implantação de uma horta caseira, investigação motivada pela crescente preocupação com o cuidado do meio ambiente e sua sustentabilidade, associada à qualidade de vida no ambiente urbano, isto do ponto de vista da Ciência Contábil, que tem por objeto o patrimônio, e na perspectiva agroecológica, se destina a redução de gastos e insumos, onde se busca contribuir por meio da ferramenta de Custos para o incentivo e disseminação do presente conceito de hortas caseiras em meio urbano. Utilizando para os fins científicos o método exploratório-descrito, por meio da técnica de pesquisa de campo e estudo de caso, buscando o objetivo de apurar, através da fixação de uma horta caseira na instituição beneficente, intitulada "Lar das Marias", seguido da descrição do processo de formação da plantação de quatro tipos de hortaliças empregadas: coentro, cebolinha, chicória e couve. De forma a permitir que durante todo o desenvolvimento do projeto houvesse a identificação dos elementos de custo e posterior classificação e listagem descriminando item a item dos insumos e da mão-de-obra utilizada. Por fim, dar-se um panorama do levantamento dos custos de implantação de uma horta caseira, bem como, a recomendação pela viabilidade e economicidade do processo.

Palavras Chave: Custos de Implantação, Hortas Caseiras, Hortaliças. 


\section{INTRODUÇÃO}

Cada fez mais se observa a crescente preocupação da sociedade com qualidade de vida no ambiente urbano, qualidade que está associada à nutrição, a saúde, a sustentabilidade e até a economia. Em virtude disso surgem hábitos propiciadores de qualidade de vida, como é o caso das hortas caseiras, objeto de estudo de nossa pesquisa, que encontra correspondência em todos os fatores elencados e não se limitando a eles. Não obstante, a Ciência Contábil como ciência social, também busca repercutir sobre esse fenômeno, delimitando-se a perspectiva patrimonial e gerencial.

Para compor uma horta caseira é necessário, além de conhecimentos relativos ao cultivo, conhecer os custos provenientes da formação de uma cultura de hortaliças; o que leva a indagação: "Quais os custos para a implantação de uma horta caseira?". Destarte, propõe-se como objetivo desta investigação, apurar os custos para implantação de uma horta caseira, alcançados por meio: da definição dos tipos produto/hortaliças que serão plantados, da descrição do processo de formação, e por fim o cálculo dos insumos e a mão-de-obra empregada no processo. Tendo o projeto de implantação, sido realizado em Instituição Beneficente intitulada "Lar das Marias", localizada na cidade de Manaus.

\subsection{CONTABILIDADE AGROPECUÁRIA}

O Brasil historicamente tem como base de sua economia o setor agropecuário, isso como marca do Período Colonial. Hoje o denominado agronegócio é uma dos mais importantes impulsores da economia nacional. A agricultura, não somente pelo ponto de vista econômico, mas pela própria repercussão social é essencial para o desenvolvimento do país.

Por sua vez, a Ciência Contábil como ferramenta gerencial de análise e mensuração do patrimônio, vem contribuir para o planejamento e acompanhamento das atividades rurais, que são essenciais para a manutenção dos negócios (MARQUES et al., 2016). Portanto, Calderelli (2003) conceitua também a nominada Contabilidade Rural como "aquela que tem suas normas baseadas na orientação, controle e registro dos atos e fatos ocorridos e praticados por uma empresa cujo objeto de comércio ou indústria seja agricultura ou pecuária".

Para Crepaldi (apud BORILLI et al., 2005, p. 83), a finalidade da contabilidade agropecuária não seria, a de gerar informações para a Declaração do Imposto de Renda, mas:

[...] medir e controlar o desempenho econômico-financeiro da empresa e de cada atividade produtiva; apoiar as tomadas de decisões no planejamento da produção, das vendas e investimentos; auxiliar nas projeções de fluxos de caixas, permitir comparações à performance da empresa com outras; conduzir as despesas pessoais do proprietário e de sua família; justificar a liquidez e capacidade de pagamento junto aos credores; servir de base para seguros, arrendamentos e outros contratos [...].

Dessa forma, o agronegócio não se limita ao simples trato com a terra ou animais, agricultura e pecuária respectivamente, porém, como bem recordado, ocupa-se ainda das despesas pessoais do proprietário, como no caso das hortas caseiras que inclusive refletem nas finanças pessoais dos seus promotores.

\subsection{CONTABILIDADE AMBIENTAL}

De outro ponto de vista a contabilidade na atualidade tem se empenhado com as questões ambientais, em vista da preocupação latente da sociedade sobre os temas relacionados à sustentabilidade, a ecologia, e aos recursos naturais. Essa atenção, a priori do campo empresarial, resultou no ramo científico que dá origem ao conceito de Contabilidade Ambiental, desenvolvido ainda no final do século XX, o qual ponderam Gonçalves e Heliodoro (2005):

A Contabilidade Ambiental é a Contabilidade dos benefícios e prejuízos que o desenvolvimento de um produto pode originar no meio ambiente. É um conjunto de acções pensadas com vista ao desenvolvimento de um projecto, tendo em conta a preservação do meio ambiente.

Deste conceito se exprimi não só a acepção empresarial, mas a extensão pessoal da contabilidade ambiental, como sendo, o desempenho de ações que favoreçam a preservação ambiental, aqui se salienta o objeto da presente pesquisa, que intenciona ser uma prática associada à preservação e sustentabilidade na 
vida dos indivíduos envolvidos, bem como do meio em que vivem. Posto que, nesse processo a contabilidade mesura os benefícios e prejuízos de um produto, versando assim sobre os custos atribuídos a cada produto, em vista do impacto causado na natureza.

\subsection{CUSTOS DA PRODUÇÃO}

Nota-se, portanto, que outra área da contabilidade é aplicada de forma direta nesse processo produtivo, qual seja, a Contabilidade voltada para os Custos, da qual se extrai da ótica de Reis (2007).

Custo de produção como a soma dos valores de todos os recursos (insumos e serviços) utilizados no processo produtivo de uma atividade agrícola, em certo período de tempo e que podem ser classificados em curto e longo prazos.

Assim sendo, o custo seria o instrumento para a mensuração da produção, seja ela agrícola ou pecuária, e posterior valoração de uso ou precificação do produto de venda. Outra característica do custo seria a variação, como destacado a seguir, por Rámiz (1988):

Os custos de produção podem variar por diversos motivos. Pode-se destacar a utilização intensiva ou não de tecnologia; o uso dos fatores, com maior ou menor eficiência, intensidade ou produtividade; o volume de produção e o preço dos fatores.

Esta característica é preponderante no custo de produção, que o faz tão importante no ramo dos negócios, pois determina o custo-benefício que trazido a quem produz e/ou utiliza esse produto agrícola.

\subsection{HORTAS URBANAS}

De forma divergente ao ambiente originário da produção agrícola, ou seja, a zona rural viu-se surgir um novo conceito de plantação, em zona urbana e de sobremaneira nas zonas metropolitanas. Decorrente do fenômeno social e demográfico da urbanização, que causa a migração da população rural para as cidades, observou-se que alguns hábitos do campo não foram abandonados como é o caso das hortas caseiras, cujo objetivo não seria a produção em larga escala, devido inclusive à limitação do espaço urbano, mas a produção para o consumo próprio ou familiar. Alinhados ao pensamento de Teixeira (2016) temos que:

As hortas urbanas representam, assim, uma das estratégias mais comuns de implementação de agricultura urbana nos países desenvolvidos. São parcelas de terreno, destinadas maioritariamente à produção hortícola, divididas em talhões de pequena dimensão e cultivadas por pessoas ou grupos de pessoas interessadas em produzir os seus próprios alimentos. Mas, para além da função produtiva, as hortas podem ter uma função terapêutica, social, económica ou educativa.

Diferente da produção para a exploração econômica das hortaliças, as hortas urbanas são destinadas a melhoria da alimentação e do meio ambiente, sendo que na produção em grande escala há, na maioria das vezes, aplicação de agrotóxicos, o que não acontece com as hortas caseiras, justificando sua relação, dentre muitas outras práticas, com a qualidade de vida em grandes centros urbanos.

\section{DESENVOLVIMENTO}

\subsection{METODOLOGIA}

O presente estudo, considerando a taxionomia proposta por Vergara (2013) que qualifica as pesquisas em relação seus aspectos: quantos aos fins e quantos aos meios. Trata-se, quanto aos fins ou com base em seus objetivos, pesquisa exploratório, posto que, busca traçar uma maior familiaridade entre o tema e o fenômeno abordado (GIL, 2002). De outro modo, devido aos objetivos norteadores, a investigação conforma-se como descritiva, pois também expõe as características do fenômeno. Sendo assim acomodase melhor no conceito de estudo exploratório-descritivo combinado, de acordo Lakatos (2003), onde estudos exploratórios têm por objetivo descrever completamente determinado fenômeno.

Quantos aos meios ou técnicas, foram utilizados: a Pesquisa de Campo, caracterizado pela observação empírica e diretamente atuante dos autores no fenômeno; isso propiciado pela Pesquisa-Ação, devido associação traçada pelo projeto de implantação dentro de uma instituição beneficente e a finalidade de 
levantamento dos custos envolvidos, ou seja, se intervindo na relação social que origina a investigação; Estudo de Caso, que se refere ao estudo minucioso e profundo do objeto, (horta caseiras/prisma de custo), de maneira que permita o seu amplo e detalhado conhecimento (YIN, 2001).

Do ponto de vista da forma de abordagem do problema, a pesquisa é de formato qualitativo, da vez que destinasse a descrição do fenômeno frente ao ambiente estudado, na qual os autores em atribuem significado aos elementos constitutivos do processo. Contudo, a pesar de no escopo da pesquisa, figurar-se objetivos meramente quantitativos, em caso, a apuração de custos, a pesquisa mantêm preponderantemente seu caráter qualitativa, sendo o formato qualitativo um realce a esse caráter.

\subsection{ANÁLISE E RESULTADOS}

Tendo em vista que a pesquisa parte de um projeto, o qual visava à ajuda a uma instituição beneficente, preliminarmente acentua-se o local onde se realizou a implantação da horta caseira, o Lar das Marias, uma entidade sem fins lucrativos, que tem por missão: abrigar e apoiar mulheres do interior do Amazonas que realizam tratamento de câncer, na Capital - Manaus.

Ao se verificar o local disponível para a instalação da horta, constatou-se a delimitação de espaço, característica típica das casas em áreas urbanas, diante disso optou-se por uma modalidade para a plantação das hortaliças, na qual se escolheu a plantação feita em vasos. Essa modalidade pode ser perfeitamente estabelecida em locais com pouca disponibilidade de espaços inclusive em apartamentos.

Neste caso, dentre o variado universo das hortaliças, sabe-se que nem todas adequam-se a modalidade de plantação em vasos, pois existem alguns tipos de hortaliças que necessitam que uma maior extensão de terra para se desenvolverem e de cuidados específicos. Além desses critérios de escolha, considerou-se o usufruto feito na alimentação das residentes do local, assim por serem objetivamente as hortaliças mais utilizadas na culinária da região, forem escolhidas: o coentro, a cebolinha, a chicória e a couve manteiga.

No processo de preparação para a instalação da horta caseira listam-se as seguintes atividades desempenhadas:

- Consulta a alunos do curso de Agronomia da Universidade Federal do Amazonas;

- Procura e aquisição dos insumos: vasos, terra adubada, mudas e sementes.

- Plantação das mudas e sementes das hortaliças escolhidas.

A primeira etapa, de consulta a estudantes de agronomia foi preliminar, ainda durante planejamento do projeto e deu-se devido limitação técnica de seus executores, essa consulta contribuiu na opção da modalidade de plantação e escolha das hortaliças.

Em seguida, vieram às fases de procura e aquisição no mercado local dos insumos a serem empregados na horta, cumpre destacar que no processo de levantamento dos custos de um produto (horta caseira) devem se levar em consideração não somente o preço dos insumos, mas de igual modo o transporte e outras eventuais despesas que surgem ao longo da aquisição do produto, contudo, não é tarefa fácil aos contadores a mensuração e rateio desses valores, logo para os fins desta pesquisa não foram esses valores que se agregam ao preço dos materiais.

Por última etapa, vieram as fases plantação da mudas e sementes e o estabelecimento da horta, encerando-se assim o ciclo de implantação da horta caseira.

Para a composição do custo, ilustramos a seguir seus elementos, que são classificados entre custos diretos e custos indiretos empregados no processo produtivo.

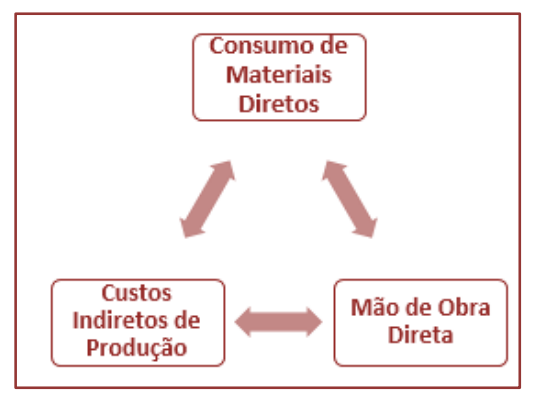


Quanto ao levantamento dos custos desta pesquisa, foi necessária a análise detalhada de todos os custos aplicados em todo o processo de implantação, ressalta-se que pela própria delimitação da pesquisa, no sentido de apuração dos custos na fase de implantação, ou seja, o que é caracterizado como Custo Primário, por excluírem os custos indiretos de produção.

Da análise foi extraída a Tabela 1, onde se apurou como custo total de formação da horta o montante de $\mathrm{R} \$ 92,50$ (noventa e dois reais e cinquenta centavos).

Tabela 1 - Detalhamento dos Custos de Implantação da Horta.

\begin{tabular}{|c|c|c|}
\hline MATERIAIS & QUANTIDADE & VALORES (R\$) \\
\hline Vasos & 4 unid. & $\mathrm{R} \$ 20,00$ \\
\hline Terra Adubada (comprada) & $5 \mathrm{~kg}$ & $\mathrm{R} \$ 10,00$ \\
\hline Terra Adubada (doada) & $10 \mathrm{~kg}$ & $\mathrm{R} \$ 0,00$ \\
\hline Mudas (cebolinhas) & 3 unid. & $\mathrm{R} \$ 10,00$ \\
\hline Mudas (chicória) & 3 unid. & $\mathrm{R} \$ 10,00$ \\
\hline Mudas (couve) & 3 unid. & $\mathrm{R} \$ 15,00$ \\
\hline Coentro (semente) & 1 pacote & $\mathrm{R} \$ 2,50$ \\
\hline Plantação das mudas & 0 & $\mathrm{R} \$ 25,00$ \\
\hline Mão de Obra Direta & 5 & $\mathrm{R} \$ 0,00$ \\
\hline Custo Total & - & $\mathrm{R} \$ \mathbf{9 2 , 5 0}$ \\
\hline
\end{tabular}

Observa-se na Tabela 1 a inexistência de alguns valores, como é o caso da Mão de Obra Direta, isso sucedeu devido o caráter voluntario da iniciativa, por outro lado, aqui é também identifica a ausência de base de mensuração a fim de se valorar o esforço humano empreendido.

\section{CONCLUSÕES}

Verificada a relevância do objeto estudado no atual contexto social, permeado pela preocupação com a sustentabilidade do meio ambiente e a qualidade de vida homem no meio urbano, isso evidenciado pela larga repercussão em diversos campos do conhecimento, bem como sua múltipla abordagem dentro da própria Ciência Contábil, no qual o presente artigo destinou-se à abordagem do objeto sobre o prisma do custo.

Dado o exposto, em atendimento aos objetivos formulados inicialmente de apuração dos custos empregados no processo na implantação de uma horta caseira com a utilização de métodos e técnicas científicas, encontram-se satisfeitos todos a requisitos preestabelecidos que resulta de pesquisa de campo e estudo de caso na Instituição "Lar das Marias". Por consequência, foi identificado que o processo de implantação da horta, caracteriza-se como a fase de Custo Primário de produção, do que se resultou apurado o valor de R\$92, 50, como sendo o custo da implantação.

Por esse motivo, a pesquisa constata que a adoção das hortas caseiras é uma iniciativa viável e que implica em baixos custos de implantação para os seus proprietários, comparado ao retorno causado ao meio ambiente a e qualidade de vida, assim recomendada pela viabilidade e economicidade do processo.

Finalmente, não tendo está pesquisa a pretensão de esgotar o assunto em comento, recomenda-se que futuras contribuições científicas sejam realizadas nesse sentido, como em caso a abordagem do custo na fase de manutenção da horta caseira; em vista, de enriquecimento do arcabouço teórico e prático do tema no campo da Ciência Contábil, e de outras áreas do conhecimento. 


\section{REFERÊNCIAS}

[1] Borilli, Salete Polônia et al. O Uso da Contabilidade Rural como Ferramenta Gerencial: Um Estudo de Caso dos Produtores Rurais no Município de Toledo - PR. Revista de Ciências Empresariais da UNIPAR, Toledo, v. 6, n. 1, p. 77 95, jun. 2005.

[2] Calderelli, Antônio, (2003) - Enciclopédia contábil e comercial brasileira, 28 ed. São Paulo: Cetec.

[3] Gil, Antônio Carlos. Como elaborar projetos de pesquisa. 4. ed. - São Paulo: Atlas, 2002.

[4] Gonçalves, Sidalina Santos; Heliodoro, Paula Alexandra . A Contabilidade Ambiental como um novo paradigma. Revista Universo Contábil , Blumenau, v. 1, n. 3, p. 81-93, dez. 2005.

[5] Lakatos, E. M.; Marconi, M. de A. Fundamentos de metodologia científica. 5. ed. - São Paulo: Atlas, 2003.

[6] Marques, André Júnio. et al. A Importância da Contabilidade Rural para o Produtor Rural no Brasil. Centro Universitário de Belo Horizonte - UNIBH. 2016.

[7] Rámiz, Antônio Argandona. Os custos. In: Enciclopédia prática de economia: questões da teoria econômica. São Paulo: Nova Cultural, 1988.

[8] Reis, Ricardo Pereira. Fundamentos de economia aplicada. Lavras: Ufla/Faepe, 2007.

[9] Teixeira, Diana Margarida da Costa Leite. Hortas Urbanas: O contributo da arquitetura para a integração das hortas urbanas na (re)qualificação da cidade. Universidade de Coimbra, 2016. Dissertação.

[10] Vergara, Silvya Constant. Projetos e relatórios de pesquisa em administração, 14ạ Ed. - São Paulo: Atlas, 2013.

[11] Yin, R. K. Estudo de caso: planejamento e métodos. 2. ed. Porto Alegre: Bookman, 2001. 


\section{Capítulo 18}

\section{A leitura em espaços não formais como estratégia pedagógica na educação ambiental*}

\section{Quemuel Alves da Silva \\ José Cavalcante Lacerda Junior \\ Evelyn Lauria Noronha \\ Maria Inês Gasparetto Higuchi}

Resumo: Com o objetivo de conhecer a relevância da prática de leituras em um espaço não formal na Educação Ambiental, o presente artigo parte do seguinte questionamento: em que medida atividades de leitura desenvolvida em um espaço não formal evidencia estratégias pedagógicas na Educação Ambiental? Como instrumento metodológico, a pesquisa tomou como ponto de partida a pesquisa bibliográfica e as rodas de conversas realizadas com crianças em um projeto pedagógico. Os resultados apontam a diversidade de espaços da cidade - ruas, praças, feiras, por exemplo - como vias apropriadas no que diz respeito ao processo educacional, principalmente, no processo de ensino-aprendizagem ocorrido na Educação Ambiental. E ainda, utilização dos espaços não formais, atravessado pela prática de leitura, oportuniza aos educandos a interação com outros sujeitos e a socialização de conhecimento, a partir de suas trocas, favorecendo aos mesmos um olhar sobre sua própria realidade.

Palavras-chave: Ambiente. Educação. Leitura. 


\section{INTRODUÇÃO}

A diversidade de espaços da cidade pode ser apropriada pelas crianças no que diz respeito ao processo educacional, principalmente, na relação de ensino-aprendizagem ocorrida nas escolas. Nesse sentido, ruas, praças, escolas, feiras, shoppings podem se constituir como lócus do processo educativo.

No campo da educação, teóricos como Chassot (2006), Jacobucci (2008), Rocha e Fachín-Terán (2010) apontam pelo menos dois modos espaciais para configurar a educação: o formal e o não formal. 0 ambiente da sala de aula diz respeito ao âmbito formal e convencionado que se tem de pensar tal processo e o não formal, que são os locais que extrapolam "os muros" da sala de aula. Tal perspectiva encontra ressonância na contribuição de Freire (2003), que entende que o conhecimento "brota" da experiência de leitura do mundo. Ler significa representar, isto é, a afirmação do sujeito, de sua história como produtor de linguagem e de sua singularização como intérprete.

Construindo uma interação entre os espaços não formais e a leitura, destaca-se que o processo ensinoaprendizagem deve estar alicerçado em espaços significativos para a vivência do conhecimento por parte do educando. Nesse sentido, o artigo parte do seguinte questionamento: em que medida atividades de leitura desenvolvida em um espaço não formal podem se configurar como estratégia pedagógica na Educação Ambiental?

Buscou-se, dessa forma, conhecer a relevância dos espaços não formais no processo educacional, bem como identificar o conceito de leitura mediante a abordagem freireana. Enquanto instrumento metodológico, a pesquisa tomou como ponto de partida a pesquisa bibliográfica, a qual está voltada para a compreensão do contexto teórico dos espaços não formais e a leitura, e, as rodas de conversa como espaço de verbalização e produção de sentidos acerca da leitura e dos elementos socioambientais presente nas atividades pedagógicas.

Nessa perspectiva, o texto está organizado em três tópicos, a saber: 1) A relevância dos espaços não formais e a leitura: fundamentação teórica; 2) 0 projeto Tarrafa na Cidade de Maraã: sujeitos e métodos; 3) A Educação Ambiental: resultados.

Assim, o processo educacional não se ocupa somente de formas de investigação da realidade, por meio de métodos que encapsulam saberes definidos e prontos. Mas, deve se originar do contexto em que o sujeito está inserido e como tal refletir sua finalidade e utilidade, reconhecendo as urgências do seu tempo. Acredita-se que os dados advindos do estudo possibilitam uma reflexão acerca da problemática da leitura, objetivando investigar os fatores que colaboram na Educação Ambiental.

\section{A RELEVÂNCIA DOS ESPAÇOS NÃO FORMAIS E A LEITURA: FUNDAMENTAÇÃO TEÓRICA}

A complexidade de nosso tempo tenciona sua discussão sobre o ser humano e sua relação com o ambiente, a qual traz em seus meandros a interdisciplinaridade como tessitura de tal conjuntura (MORIN, 2005). Assim, a compreensão da Educação Ambiental articula-se na relação com a complexidade planetária e isso "toca" suas práticas pedagógicas, as quais podem compartilhar significados e reflexões que transcendam seu escopo epistemológico, seja em seu processo de construção teórica seja no ensino-aprendizagem.

A escola não pode mais ser considerada o recinto exclusivo de todo o saber que advém do processo educativo. Outros espaços constituem-se como possibilidades e devem ser apropriados para a construção da Educação Ambiental. A apropriação desses novos espaços emana uma reflexão pautada em novas metodologias que visam um maior empenho na aproximação maior e real dos fenômenos ora estudado com a realidade do educando. Daí, reside a importância dos espaços não formais.

Jacobucci (2008) destaca que espaços não formais são entendidos como aqueles, diferentes da escola, que possibilitam uma prática educativa. Para tal existem os locais que são institucionalizados, os quais disponibilizam uma estrutura, planejamento e organização e os locais não institucionalizados que não possuem uma estrutura voltada para a finalidade educativa.

Dessa maneira, a construção de processos educativos em espaço não formal caracteriza-se por sua dinamicidade, pois, incluem em seu repertório estudos do meio, visitas externas, excursões, passeios, mostras pedagógicas, etc. São processos que não são estáticos, mas sempre abertos as variáveis que podem advir do contexto no qual está inserido, bem como a diversidade com a qual se pode entender e captar a Educação Ambiental.

Diferentes atividades podem ser realizadas fora do ambiente da sala de aula. No entanto, ressalta-se que o estabelecimento das estratégias determina a intensidade e o significado com que a atividade terá para com 
os educandos. Daí a necessidade, de planejar a execução de tal atividade, tendo como pressuposto que nenhum planejamento é fechado em si mesmo, mas que se adapta de acordo com as variáveis que surgem no decurso do processo.

É nesse sentido, que o desenvolvimento de rodas de conversas por meio do estímulo à leitura pode encontrar profícuo terreno na Educação Ambiental. A utilização dos espaços não formais aliado ao desenvolvimento de hábitos de leitura pode despertar uma atenção às diferentes variáveis que interferem no processo de ensino-aprendizagem.

Para Freire (2003) educar não é apenas uma transferência da inteligência do objeto ao educando, mas uma provocação no sentido de que, como sujeito cognoscente, torne-se capaz de inteligir e comunicar o inteligido, isto é, possa conhecer a realidade e conhecendo transmita ao outro a dinâmica da história que constrói a vida. Essa perspectiva freireana (2003) ressalta uma educação fundada na ética, no respeito à dignidade e à própria autonomia do educando, a qual possibilita a capacidade de construir, reconstruir, constatar e mudar em relação realidade.

Por esta via, nota-se que pela leitura pode haver uma emancipação do ser humano, isto é, da condição de mero espectador do mundo, onde a submissão é uma característica, para agente ativo e transformador.

Educar é construir, é libertar o ser humano das cadeias do determinismo neoliberal, reconhecendo que a história é um tempo de possibilidades. É um 'ensinar a pensar certo' com quem 'fala com a força do testemunho'. É um 'ato comunicante, co-participado', de modo algum produto de uma mente 'burocratizada'. No entanto, toda a curiosidade de saber exige uma reflexão crítica e prática, de modo que o próprio discurso teórico terá de ser aliado à sua aplicação prática (FREIRE, 1996, p.52).

Tal transformação germina da própria realidade concreta demonstrando, assim, a construção dialética de uma nova história. Ora, a consequência desta perspectiva é a construção de um processo educacional democrático, livre, atuante e, acima de tudo, que possibilita a autonomia. Assim, o ser humano, seja ele educador ou educando, atua na história não apenas como objeto na massa, mas como sujeitos participantes da história, ocasionando, assim, a desalienação. Para tal conjuntura, a visão freireana possui uma natureza construtivista no sentido que se configura como um projeto de vida, de esperança, donde há uma busca continua pela dignidade e negação direta de toda e qualquer forma de opressão e injustiça.

A leitura para Freire (2003) consiste em ler a realidade com um aguçado olhar e lançar-se as mudanças, tendo em vista que nosso mundo hodierno é marcado pelo abismo da desigualdade. Conhecer é ler e ler é transformar. E ainda, a leitura instiga o educando a sair do simples papel "engolidor" de ideias para a desafiante tarefa de interpretar e reinventar o mundo buscando a verdade e libertando-se dos grilhões do não-mundo. 0 leitor deve ser sujeito.

Isto significa que é impossível um estudo sério se o que estuda se Poe em face do texto como se estivesse magnetizado pela palavra do autor, à qual emprestasse uma força mágica. Se se comporta passivamente, 'domesticadamente', procurando apenas memorizar as afirmações do autor. Se se deixa 'invadir' pelo que afirma o autor. Se se transforma numa 'vasilha' que deve ser enchida pelos conteúdos que ele retira do texto para pôr dentro de si mesmo (FREIRE, 1987, p.10).

Nesse contexto, não basta entender somente o que está impresso ou o que se depreende dos signos linguísticos. A concepção de leitura e de ser humano freireano são utópicos? A resposta pode ser encontrada na própria maneira de viver do educador da libertação. "Freire é um realista por que é utópico, e utópico e esperançoso por que, para além dos textos sabe ler a realidade" (DAMKE, 1998, p.41). Em outro texto continua "só os utópicos [...] podem ter esperança, só os oprimidos podem libertar-se a si mesmos e libertar seus opressores" (TORRES, 1979, p.8). A perspectiva freireana perpassa, a partir do ato de ler, pela epifania de um novo tipo de sociedade e cidadão.

Ler é uma operação inteligente, difícil, exigente, mas gratificante. Ninguém lê ou estuda autenticamente se não assume, diante do texto ou do objeto da curiosidade a forma crítica de ser ou de estar sendo sujeito da curiosidade, sujeito da leitura, sujeito do processo de conhecer em que se acha. Ler é procurar buscar criar a compreensão do lido; daí, entre outros pontos fundamentais, a importância do ensino correto da leitura e da escrita. É que 
ensinar a ler é engajar-se numa experiência criativa em torno da compreensão. Da compreensão e da comunicação (FREIRE, 2001, p. 261).

Assim, o educando, enquanto sujeito de sua ação, deságua numa perspectiva libertadora, que tende, consequentemente, ao desvelamento de um ser utópico e ético, que ao ler a realidade se descobre e transforma o meio que o circunda. Nesta acepção, a relação entre o espaço não formal e a leitura da realidade torna-se imprescindível para a construção de uma perspectiva em que a Educação Ambiental, enquanto processo, aproprie-se da dinâmica social, construindo assim, condições que oportunizem a leitura dos códigos linguísticos que efetuam as relações sociais, assim, como ler os meandros ideológicos que perpassam os enlaces sociais. Assim, passaremos a conhecer como é possível articular a leitura e o espaço não formal na composição do Projeto Tarrafa.

\subsection{PROJETO TARRAFA NA CIDADE DE MARAÃ: SUJEITOS E MÉTODOS}

O Projeto Tarrafa é uma proposta pedagógica do Departamento de Cultura da Secretaria Municipal de Educação de Maraã que visa fomentar o desenvolvimento de atividades pedagógicas em espaços não formais mediante práticas lúdicas aos educandos da rede municipal de ensino desta cidade. Segundo dados do IBGE (2016), Maraã é um dos 62 municípios do Estado do Amazonas localizado na margem esquerda do Rio Japurá com uma distância via fluvial da capital, Manaus, de $920 \mathrm{~km}$. Possui um uma população estimada de 18.477 habitantes para 2016.

Figura 1 - Tarrafa - símbolo do projeto

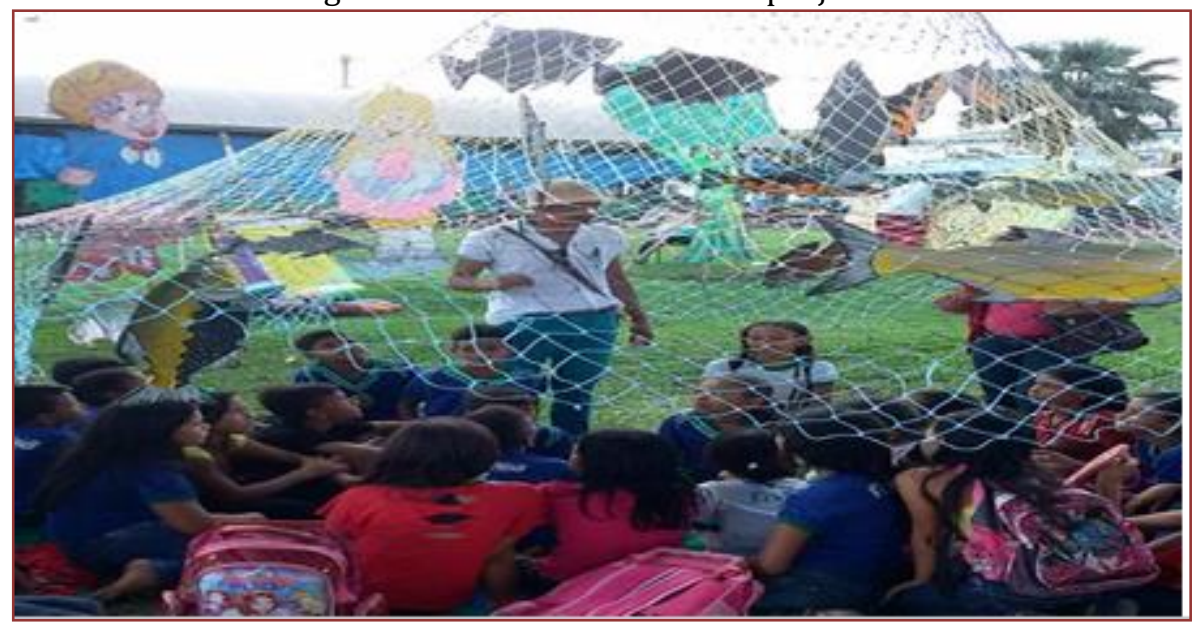

Fonte: QUEMUEL, Alves da Silva, 2016

O nome dado ao projeto é uma homenagem aos pescadores ribeirinhos da Amazônia que utilizam a Tarrafa (Fig. 1), isto é, utensílio de pesca circular como pesos nas extremidades e um cabo no centro que facilita o manuseio pelo pescador. Essa prática é muito conhecida pelos ribeirinhos de Maraã, pois utilizam tarrafa para pescar a variedade de espécies de peixes nos rios e lagos amazônico.

Partido dessa prática ribeirinha, o Projeto Tarrafa em suas metas busca alcançar as crianças, adolescentes e jovens da comunidade maraaense, levando em consideração os aspectos socioambientais, suas particularidades, seus valores, seus costumes, suas falas, seus modos. Reconhecendo o processo educativo possui um caráter diverso e plural no que diz respeito aos seus conteúdos, formas e atores. E ainda, o referido projeto surge pela necessidade de espaços pedagógicos que favorecessem a interação dos educandos com os espaços da cidade de Maraã.

Como metodologia, o projeto funciona mediante mostras pedagógicas realizadas nos espaços públicos da cidade de Maraã, tendo as rodas de conversas como momento de produção de sentidos, socialização e avaliação das atividades pedagógicas desenvolvidas. Com efeito, como o projeto se orienta por meio das rodas de conversas que possuem a finalidade de desvelar, por meio das vozes dos educandos, os sentidos e significados das atividades pedagógicas desenvolvidas pelo projeto. Enquanto método, a roda de conversa (Fig. 2) é um momento de ressonância coletiva desenvolvida a partir de um espaço de diálogo, autonomia e construção de conhecimentos. 


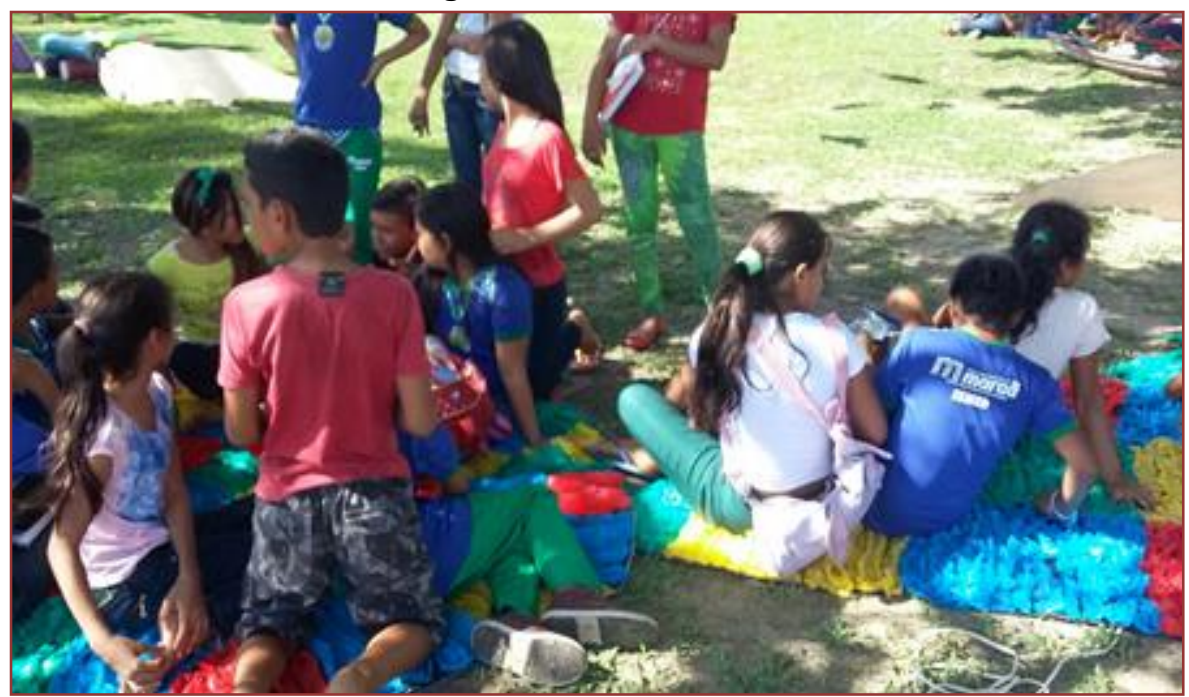

Fonte: QUEMUEL, Alves da Silva, 2016

Diferentemente de Leporo e Dominguez (2009), que consideram as rodas de conversas como um momento marcado por regras, silêncio e outras normas. Entende-se que as rodas de conversas, consoante a De Angelo (2011), são atividades significativas em que os educandos, como sujeitos da fala, desempenham um papel ativo nos diálogos e trocas de ideias. Dessa forma, as rodas de conversas aconteciam quando o contexto solicitava uma abertura de discussões e combinados acerca de cada procedimento que seria desenvolvido no processo de investigação, mas também, em momentos espontâneos em que as crianças verbalizaram no espaço.

A roda de conversa pode se dar em diferentes momentos ou situações. Nos momentos instituídos (itálico do autor), aparece como parte do planejamento realizado pela educadora e tem por grande objetivo a construção de ideias em torno de um tema gerador e das atividades necessárias para o desenvolvimento do processo, ou também como momento de partilha de informações, vivências e experiências pessoais. [...] Contudo, a roda de conversa pode se configurar nos momentos em que determinadas situações surgem e precisam ser resolvidas, conflitos precisam ser geridos, precisam ser tomadas, idéias mais complexas precisam ser discutidas. Nos momentos exigidos a educadora, como alguém que identifica as tensões que vão surgindo no interior do grupo, propõe a realização de uma conversa, em que a situação é confrontada por todos e em torno da qual se vão dando variações que são a contribuição de cada um. (De Angelo, 2011, p. 62-63).

Para esse artigo, será apresentado os resultados da primeira mostra pedagógica do Projeto Tarrafa realizada em junho ano 2016, tendo a Praça da Igreja Imaculada Conceição como espaço não formal. A razão da escolha desse espaço se deu pelo fato de tal praça concentrar nas suas proximidades a maioria das instituições educativas como creches, instituições religiosas, departamento de assistência social, conselho tutelar, secretarias municipais de meio ambiente, educação saúde e escolas estaduais e municipais dentre outros órgãos.

0 espaço é arborizado e fica próximo ao rio (Fig. 3), às matas e às atividades ribeirinhas. Ele concentra uma aglomeração de pessoas pelo fato de ficar próximo ao mercado municipal da cidade, onde os pescadores e feirantes se reúnem para a venda de peixes e verduras, tendo assim varias características das atividades regionais uma vez que o projeto objetiva aproximar os educandos do ambiente que os cerca. 


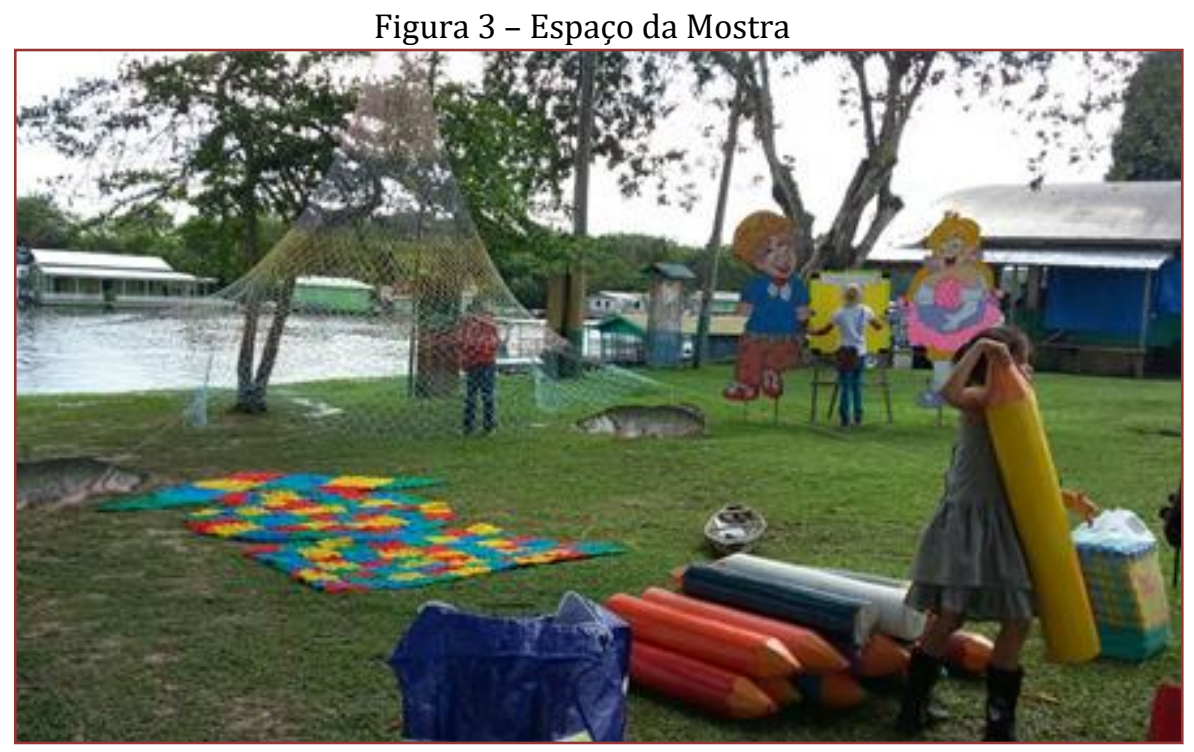

Fonte: QUEMUEL, Alves da Silva, 2016

Por conta de ser a primeira mostra pedagógica, participaram 36 alunos do 5o ano da Escola Municipal Darcy Barbosa Littaif. A escolha da referida série é resultado de um levantamento prévio a realização da mostra pedagógica. Após o diagnóstico percebeu-se que havia lacunas e fragmentações no que diz respeito à aprendizagem dos educandos, bem como o não uso dos espaços não formais no planejamento das atividades escolares. Dessa maneira, realizou-se as seguintes atividades pedagógicas:

1) Apresentação do projeto Tarrafa: com o objetivo refletir o seu significado, em uma roda de conversa. As crianças puderam expressar e discutir sobre a importância da leitura e como essa prática se dava no quotidiano de cada um, logo após pediu que todos escrevem numa folha de papel o que significava para eles "leitura".

2) Ditado de palavras: a atividade usou figuras representativas do seu dia-a-dia, como malhadeira, remo, rio, lago, árvore, floresta, peixe, cuia, chapéu, canoa, caniço, isca, curral, folha, fogo, fauna, flora", dentre outras palavras para aproximar a escrita do contexto socioambiental dos educandos.

3) Produção de frases: esse momento teve a finalidade de organizar e selecionar frases que continham o nome dos peixes amazônicos, como pirarucu e tambaqui por exemplo. Em seguida teriam que produzir um pequeno texto sobre os peixes amazônicos e teriam que escolher um colega para fazer a leitura do texto.

4) Tenda do cinema: nesse espaço as crianças assistiram um documentário a respeito do lixo. Nesta atividade teriam que discutir entre si e juntos produzirem uma carta para fixar no mural da escola com o tema, "o mundo é meu quintal".

5) Montagem de quebra cabeça das palavras: os educandos deveriam organizar as letras para composição de uma palavra e em seguida escrevê-las em um quadro branco. Nesse espaço tinha o cantinho da leitura, onde foi montado em um tronco de uma árvore, todos ficaram encantados com o lugar.

Assim, após as atividades, os educandos foram conduzidos para o gramado para realizar a roda de conversa com o intuito de alcançar os assuntos correlatos a Educação Ambiental, transformando-as em um suporte para o entendimento e construção das atividades pedagógicas, como Leituras de histórias infantis, jogos de memória, cine educação, gincana ambiental e produções textuais. Por fim, ressalta-se que tais atividades pedagógicas foram desenvolvidas de acordo com os conteúdos programáticos da série dos educandos.

\section{A EDUCAÇÃO AMBIENTAL: RESULTADOS}

Fundamentalmente, o Projeto Tarrafa compreende que é impossível conceber as questões ambientais apartadas das questões humanas. Como tal, essa perspectiva ancora-se no reconhecimento de uma Educação Ambiental que vislumbre a compressão da organicidade do meio. 
Acredita-se em uma Educação Ambiental como uma nova filosofia de vida e que deve permear o nosso fazer científico e acadêmico. Não como uma educação apenas ecológica que busca, no conhecimento das relações entre seres vivos e seu ambienta natural, explicações parciais para fatos observáveis. Não como atividades esporádicas que coloquem as pessoas em contato com a natureza por um tempo limitado da vida. Não como disciplina a ser inserida nos currículos escolares e que pode se perder em mais um dos compartimentos de nossa prática cartesiana (LINDNER, 2012, p. 15).

Nessa esteira, Marques; Carniello; Guarim Neto (2010) observam que a Educação Ambiental busca não só a conservação dos meios naturais, mas a valorização dos seres que neste meio vivem, desde valorizar sua importância social a respeitar sua cultura. Nessa mesma perspectiva, Dias (2004) compreende a Educação Ambiental como o processo por meio do quais o indivíduo e a coletividade constroem valores sociais, conhecimentos, habilidades, atitudes e competências voltadas para a conservação do ambiente e o reconhecimento cultural.

Dessa forma, a prática da leitura em espaços não formais pode se configurar numa singular estratégia em Educação Ambiental à medida que a mesma se torna uma ferramenta para a posição do educando diante da realidade socioambiental que o cerca, inclusive, quando emerge dificuldades no hábito de leitura por parte dos educandos participantes da mostra, como era referendado pelos professores que acompanharam os educandos no projeto.

Dessa necessidade, a leitura em espaços não formal por meio do Projeto Tarrafa buscou apresentar uma estratégia que aproximasse os educandos ao universo dos signos por intermédio do espaço não formal. Por isso, discutir a importância da leitura através do uso dos espaços não formais, envolvendo os aspectos socioambientais é, acima de tudo, respeitar as particularidades dos educandos tendo em vista a valorização do ambiente e o processo de aprendizagem dos códigos linguísticos. 0 planejamento para se trabalhar fora da sala de aula usando os símbolos e os instrumentos da leitura dão uma maior relevância no diz respeito à leitura e sua interpretação em um contexto geral.

Nesse sentido, o processo de ensino-aprendizagem apresenta a característica da dinamicidade e para que se torne de fato significativa para o aluno o professor deverá: "mais do que o simples resultado de atribuição de um significado a uma informação nova" (VALADARES, 2011, p.38) deverá ter consciência de que o processo educativo ambiental é um processo dinâmico, onde as atividades serão planejadas com o intuito de aprofundar seus conhecimentos prévios e ampliar novas ancoragens cognitivas. É importe frisar que, o conhecimento atribuído pelos educandos é de suma importante para a efetivação de suas identidades na construção de sujeito onde se insere.

Desse modo, ao serem questionados sobre quem gostava de ler, poucos levantaram as mãos e alguns diziam que não tinham tempo para essa prática. Nesse sentido, foi questionado se a leitura possuía alguma importância para eles. Conforme o Jaraqui11: "para mim a leitura me faz conhecer novos lugares e também pessoas tipo, os caras das histórias, o universo e várias coisas". Pode-se observar na verbalização acima a associação da leitura a capacidade de imaginativa. Aspecto que é reforçado pela voz de o Tambaqui quando diz: "acho que leitura me faz viajar. Tipo ir a Paris e outros lugares e voltar, acho que também, faz a gente conhecer as históricas bíblicas e outras coisas, na verdade, leio pouco".

Nota-se que o exercício da pela leitura favorece o desenvolvimento e a construção de imagens e representações da realidade. Sabe-se que as imagens constituem-se em um vasto campo de simbolização do humano, o qual sinaliza uma interpretação do mundo que está ao seu entorno. Em relação a leitura, as imagens representam uma forma de captar aquilo que está ao redor e integrá-lo às vivências individuais. Movimenta-se dessa forma, hábitos, referências e sentidos para coadunar diante daquilo que aparece, uma vez que de acordo com Wulf (2013) a capacidade imagética é parte indubitável da condição humana: "podemos ver a imaginação e sua capacidade de conceber imagens em ação no processo pelo qual um pedaço da natureza é transformado em um instrumento esteticamente concebido". (WULF, 2013, p.24)

Em uma das falas dos educandos, a leitura está associada à condição de libertação, conforme expressa a Pirarucu: "a leitura também liberta, sempre ouço minha mãe falar isso pra mim. Eu não entendo o que ela quer dizer". Percebendo a necessidade de explicar tal sentido, veio à baila outro questionamento devolvido aos educandos: "a leitura ajuda entender o mundo? Sim ou não?". Muitos responderam: "acho que sim" e outros "acho que não". Diante dos interpelamentos, pode-se explicitar que a leitura, também, é

110 nome dado aos educandos contempla o nome dos peixes amazônicos! Antes dos nomes, será indicado o artigo a para as meninas e o artigo o para os meninos. 
libertadora e nos levar a viajar e conhecer o desconhecido nos desprendendo das amarras. Essa perspectiva encontra assento na visão freireana (1987), onde a leitura de um texto provoca muito mais que o ato de decifrar do significado das palavras, mas deve evocar um espírito investigador, criativo e autônomo.

O uso do espaço não formal oportunizou estabelecer um vínculo entre a escola e a cidade. 0 projeto possibilitou que os educandos tivessem acesso a diferentes métodos, formas, símbolos e signos que possibilitassem vivenciar momentos de aprendizagem, entretenimento e de reflexão crítica, valorizando e reconhecendo sua cultura regional. No ditado de palavras, por exemplo, quando foi perguntado se sabiam identificar os peixes fixados na tarrafa, a maioria respondeu de forma afirmativa: "eu sei, é um surubim", diz o Tucunaré.

Nesse caso, a aproximação dos educandos com os elementos da cultura oportuniza uma conexão com o ambiente constituído de possibilidades metodológicas que visam às circunstâncias do educando. Nessa esteira, o ponto de partida para uma Educação Ambiental significativa é o encontro dos educandos com determinado fenômeno em um espaço. As causas, os efeitos, as descobertas e suas sistematizações conduzem o aprender e o significado dos conceitos e revelam suas percepções construídas a partir de sua ontologia com o meio ambiente.

Outro elemento, destacado na roda de conversa é a relação de pertencimento para o com o espaço visitado. 0 espaço da praça da matriz, constituído como espaço de ensino-aprendizagem torna-se atraente para o estudo do meio ambiente e de aspectos ecológicos, como o estudo da biodiversidade - fauna e flora por exemplo -, análise do tipo de solo: permeável ou não-permeável e sobre a coleta e seleção do lixo existente no ambiente, conforme destaca a Aruanã: "ainda bem, que a praça está limpa hoje! A cidade deveria ter mais lugares para as pessoas jogarem lixo. [...] vou guardar o meu (lixo) pra jogar na em casa. Essa compreensão coloca em cena a percepção do espaço da cidade e sua percepção acerca do ambiente integrado a perspectiva da relação como um organismo vivo, que se regula a partir do bom funcionamento de suas partes, interligadas em um dinâmico processo, revelando aquilo que Maturana e Varela (2001) chamam de autopoiesis.

E ainda, a utilização dos espaços oportunizou aos educandos a interação com outros sujeitos e a socialização de conhecimento, a partir de suas trocas, favorecendo aos mesmos, a leitura crítica e dinâmica do mundo mediante o uso de sua própria realidade. "Achei legal vir pra praça porque aqui a gente não fica parado. A gente pode fazer as coisas e ficar conversando", diz o Matrinxã. Durante o desenvolvimento de todas as atividades, por intermédio da leitura, as crianças puderam reconhecer o real, ao mesmo tempo em que o representava através de signos e outras formas simbólicas para apropriação do conhecimento.

A relação da criança com o meio ambiente postula as crianças como atores sociais, que na interação com seus pares evidenciam os significados emergentes na relação com o ambiente. Tal sentido, encontra aporte nas ideias de Toren (2013, p.175) que dizia: "cada criança precisa dar significado por si mesma ao mundo habitado". A Educação Ambiental deve aproximar a conexão dos educandos com o ambiente para realizar uma ancoragem na realidade próxima da vivência da criança, onde o mesmo se apropria e recria tal conhecimento em seu contexto, estabelecendo, também, um vínculo cognitivo e afetivo que emerge desse contato.

Com efeito, ao passo que muitos educandos compreendiam os símbolos e sabiam transcrever pela escrita os enunciados, alguns possuíam dificuldades de representá-los graficamente: "professor eu não sei escrever surubim", como a Pacu. Tal situação ilustra o que Salles e Parente (2012, p. 323) evidenciam: "a compreensão da leitura requer capacidades cognitivas, como a elaboração de inferências, e lingüísticas, como conhecimento do vocabulário, da sintaxe, entre outras".

Observa-se que a interação das crianças com o ambiente promoveu uma ampla leitura de mundo, o espaço fora da sala de aula e o contato com formas representativas vivenciadas pelas crianças possibilitaram uma agregação e apropriação de conhecimentos eficaz, conforme destacou a Bodó: "Professor eu conseguir fazer a palavra que parecia ser tão difícil", que apresentava dificuldade na produção da escrita. Muitas crianças ficam limitadas dentro de uma sala de aula ou da escola o que destoa da característica exploratória que as mesmas possuem.

Muitas das crianças de Maraã estão acostumadas com uma rotina de interação com vizinhos, com outras crianças, parentes, colegas, idosos dentre outros, e com essa socialização constrói a sua personalidade se apropriando de outros tantos conhecimentos, participando ativamente, de seus valores, sua cultura, seus jeitos de ser, suas falas, seus saberes, sua compreensão como ser participativo de modo que esse 
multiculturalismo (SANTOS, 2003), sociável e interativo, reflita na sua construção da identidade dos sujeitos.

Por fim, um outro elemento a ser destacado é que na realização das práticas pedagógicas na mostra estabelece uma relação direta com os conteúdos e podem facilitar o entendimento de mundo dos educandos. Estar fora da sala de aula e trabalhar inúmeros conteúdos onde os educandos possam expressar suas falas possibilitam a valorização dos direitos de um ensino participativo, integrador e dinâmico. A relação entre o espaço não formal e a leitura da realidade torna-se imprescindível para a construção de uma perspectiva em que o processo de ensino-aprendizagem se aproprie da dinâmica social, possuindo assim, condições de ler códigos linguísticos que efetuam as relações sociais, assim, como ler os meandros ideológicos que perpassam os enlaces sociais (FREIRE, 2003).

\section{CONSIDERAÇÕES FINAIS}

As últimas décadas inúmeras mobilizações com o intuito buscar soluções que viessem melhorar a relação do ser humano com o ambiente. Reuniões e Assembleias, como a Eco 92 e a assinatura do Protocolo de Kioto em 1997, por exemplo, movimentam tanto a esfera pública como a privada a pensar sobre a situação ambiental do planeta.

Alicerçado nessa perspectiva, a Educação Ambiental aponta para um contexto, onde inúmeros elementos criam e recriam formas de conhecimentos e expressões indicando possibilidades de como pensar e desenvolver práticas para com ambiente, mas, fundamentalmente, de reconhecer a integralidade na relação ser humano com o ambiente.

Enquanto processo é possível pensar e reconhecer por intermédio dessa percepção modos alternativos de pensar, abrindo-se a modos e maneiras diferentes de conceber e produzir práticas sustentáveis, transfigurada numa realidade polifônica que harmoniza as diferentes nuances que atravessa o contexto contemporâneo em face de uma visão holística.

É nesse sentido, que durante todas as atividades os educandos demonstraram interesse para participar, mesmo encontrando dificuldades na realização dos comandos. Acredita-se que com as atividades apresentadas, pode-se auxiliar as crianças no encontro com a realidade, possibilitando inúmeras leituras e interpretações. Durante a programação destacou-se a importância do ambiente e seu reflexo na vida de cada um, sensibilizando-os assim, para preservação e valorização do meio natural que é ofertado ao ser humano, e, que esse humano precisa cuidar e saber viver com o ambiente criando uma relação saudável.

Assim, nessa esteira, o processo educativo ambiental deve apontar para um contexto atravessado por múltiplos cenários, por uma pluralidade de aspectos que se entrelaçam, criando uma teia complexa e dinâmica que circulam influências, interesses e ideologias, constituindo-se como espaço da diversidade, onde inúmeros elementos criam e recriam formas de conhecimentos e expressões indicando possibilidades de como pensar e desenvolver práticas sustentáveis para com o ambiente.

\section{REFERÊNCIAS}

[1] Chassot, Attico. Alfabetização Científica: questões e desafios para a Educação. 4. ed. Ijuí: Ed. Unijuí, 2006.

[2] Damke, Ilda Righi. Paulo Freire: o pensador que teorizou a prática, questionou a educação e sistematizou uma teoria do conhecimento. Revista de Educação AEC, São Paulo, n.o 107, p. 31-48, 1998.

[3] De Angelo, Adilson. O espaço-tempo da fala na Educação Infantil: a roda de conversa como dispositivo pedagógico. In.: Rocha, Eloisa Acires Candal; Kramer, Sonia (Orgs.). Educação Infantil: enfoques em diálogo. Campinas, SP: Papirus, 2011.

[4] Dias, G. F. Educação ambiental: princípios e práticas. São Paulo: Gaia, 2004.

[5] Freire, Paulo. A importância do ato de Ler: em três artigos que se completam. 44. Ed. São Paulo: Cortez, 2003. . Pedagogia da Autonomia: Saberes necessários a prática educativa. São Paulo: Paz e Terra, 1996. . Ação Cultural para Liberdade. 8aㅡ ed. Rio de Janeiro: Paz e Terra, 1987.

[8] _ Carta de Paulo Freire aos professores. In.: Estudos Avançados 15 (41) 2001. Disponível em: http://www.e-educador.com/index.php/artigos-mainmenu-100/160-carta-de-paulo-freire-aos-professores. Acessado no dia 02 de set. de 2016. 
[9] Instituto Brasileiro de Geografia e Estatística - $\quad$ IBGE. Maraã. In.:<http://cidades.ibge.gov.br/xtras/perfil.php?lang=\&codmun=130280\&search=||infogr\%E1ficos:informa\%E7\%F5Bes-completas>. Acessado no dia 15 de agosto de 2016.

[10] Jacobucci, Daniela Franco Carvalho. Contribuições dos espaços não formais de educação para a formação da cultura científica. Em extensão, Uberlândia, V.7, p. 55-66, 2008.

[11] Lindner, Edson Luiz. Refletindo sobre o Ambiente. In.: Lisboa, Cassiano Pamplona; Kindel, Eunice Aita Isaia. Educação Ambiental: da teoria à prática. Porto Alegre: Mediações, 2012.

[12] Leporo, Natalia; Dominguez, Celi Rodrigues Chaves. Rodas de Ciências na Educação Infantil: as negociações de sentidos. VII ENPEC, 2009.

[13] Maturana, Humberto R.; Varela, Francisco J. A árvore do conhecimento: as bases biológicas da compreensão humana. São Paulo: Palas Athena, 2001.

[14] Morin, Edgar. Ciência com Consciência. 8. ed. Rio de Janeiro: Bertrand Brasil, 2005.

[15] Marques, L. M.; Carniello, M. A.; Guarim Neto, G. A percepção ambiental como papel fundamental na realização de pesquisa em educação ambiental. Projeto Saber. Revista Travessias. Vol. 4, N 3, 2010.

[16] Rocha, Sônia Claudio Barroso da. Fachín-Terán, Augusto. 0 uso de espaços não formais como estratégias para o Ensino de Ciências. Manaus: Uea/Escola Normal Superior/Ppgeeca, 2010.

[17] Salles, Jerusa Fumagalli de; PARENTE, Maria Alice de Mattos Pimenta. Processos Cognitivos na Leitura de Palavras em Crianças: Relações com Compreensão e Tempo de Leitura. IN.: Psicologia: Reflexão e Crítica, 2002, 15(2), pp. 321-331.

[18] Santos, Boaventura de Souza. Dilemas do nosso tempo: globalização, multiculturalismo e conhecimento (entrevista com Boaventura de Souza Santos). Currículo sem fronteiras, v.3, n.2, pp. 5-23, Jul/Dez, 2003.

[19] Toren, Christina. Uma antropologia além da cultura e da sociedade: entrevista com Christina Toren. IN.: Revista Habitus. Vol.11. n.1. Ano 2013.

[20] Torres, Carlos Alberto. Diálogo com Paulo Freire. São Paulo: Loyola, 1979. (Coleção Paulo Freire, v.II).

[21] Valadares, Jorge. A teoria da aprendizagem significativa como teoria construtivista. Aprendizagem Significativa em Revista/Meaningful Learning Review - V1(1), pp. 36-57, $2011 . \quad$ In: http://www.if.ufrgs.br/asr/artigos/Artigo_ID4/v1_n1_a2011.pdf. Acessado no dia 04 de abril de 2016.

[22] Wulf, Cristoph. Homo Pictor: imaginação, ritual e aprendizado mimético no mundo globalizado. Tradução de Vinícius Spricigo. São Paulo: Hedra, 2013. 


\title{
Capítulo 19
}

\section{Interdisciplinaridade no saber: Uma proposta de educação e cidadania}

\author{
Maiara de Souza Nunes Ávila \\ André Niedersberg de Ávila \\ Michele Pantoja Duque \\ Suziane Araújo Amorim \\ Aderlany Laranjeira \\ Jorney Moreira Barbosa
}

Resumo: 0 projeto Interdisciplinaridade no saber: uma proposta de educação e cidadania propôs uma relação orgânica entre obras assistenciais que atendem a comunidades carentes e a comunidade acadêmica. A Obra Assistencial Chico Xavier, localizada no Bairro Jardim Amanda, em Itacoatiara, AM, desenvolve trabalhos voluntários na comunidade de forma contínua, contribuindo para a formação religiosa e cidadã das pessoas envolvidas. A função desse projeto foi aliar a esse trabalho voluntário, o saber acadêmico, com a realização de oficinas teórico-práticas: de conscientização e promoção de alimentação saudável e cultivo de hortas urbanas, de compostagem doméstica, de produção de tintas naturais e orgânicas, a partir de plantas, de reciclagem de garrafas pet na horta e de arte e artesanato. As oficinas serviram como instrumentos de transformação de percepção e realidade e possibilitou a interação entre pessoas da comunidade, estudantes da Universidade e os trabalhadores voluntários da Instituição, havendo troca de experiências e educação intercultural. Os encontros foram semanais, distribuídos entre as oficinas de arte e as atividades com a compostagem, com a produção de substratos e mudas e o cultivo da horta comunitária. Ao final, os objetivos propostos foram alcançados, o projeto promoveu a interdisciplinaridade na formação de cidadãos que vivem nesta comunidade carente. Proporcionou também uma interação e integração entre a comunidade que expôs suas necessidades e a Universidade que levou o conhecimento e perspectivas futuras.

Palavras Chave: Educação ambiental, compostagem doméstica, artes plásticas. 


\section{INTRODUÇÃO}

De acordo com os Parâmetros Curriculares Nacionais para a Educação Básica (1997): “O ser humano que não conhece arte tem uma experiência de aprendizagem limitada, escapa-lhe a dimensão de sonho, da força comunicativa, dos objetos a sua volta, das cores e formas dos gestos e luzes que buscam o sentido da vida." Ações voltadas para a formação plena dos cidadãos podem colaborar com o reconhecimento e consciência de seu papel na sociedade.

O ensino de arte melhora a autoestima, desperta e desenvolve potencial criativo. É fundamental para desenvolver aspectos cognitivos, sensíveis e culturais. 0 ensino de artes significa articular os três campos conceituais, o fazer artístico, apreciação e reflexão.

A interdisciplinaridade consiste em uma abordagem em que duas ou mais disciplinas intencionalmente estabelecem nexos e vínculos entre si para alcançar um conhecimento mais abrangente, diversificado e unificado (Coimbra, 2017). Nesse ínterim, coadunar as artes plásticas com educação ambiental, permite estimular a criatividade, a autoestima e percepção e a consciência do indivíduo na sociedade.

A produção doméstica e orgânica de olerícolas e plantas medicinais aproxima o indivíduo da natureza e de seus saberes. As hortas em escolas têm demonstrado a sua importância sócio-educacional, em que a associação da teoria e prática torna-se mais estimulante no aprendizado, melhorando o entendimento dos alunos em relação aos conteúdos vistos (Mousinho et al., 2014). Desenvolve o senso de responsabilidade e cooperação em busca da preservação ambiental (Morais et al., 2014), socializa esse conhecimento junto aos seus familiares (Santos e Lima, 2014). Diversifica e estimula alimentação saudável (Santos et al., 2014).

No cultivo de hortaliças, é comum o uso de agrotóxicos e isso tem levado a uma demanda cada vez maior por produtos orgânicos, por isso há necessidade de se produzir alimentos com técnicas que respeitem os processos ecológicos e promovam a segurança alimentar (Sediyama et al., 2014). Atualmente, é crescente a busca por mais conhecimento sobre horta doméstica e sobre produção de alimentos de forma segura e sustentável. Algumas técnicas de cultivo orgânico podem ser adaptadas à dimensão urbana, como é o caso da compostagem doméstica, que alia o reaproveitamento de restos de alimentos, como cascas de frutas e verduras e a adubação da horta e produção caseira de hortaliças.

O composto é um tipo de adubo utilizado como fonte de matéria orgânica e que melhora as propriedades físicas do solo, como textura e estrutura. Além disso, melhora a fertilidade e garante a capacidade de troca catiônica, disponibilizando os nutrientes para as plantas, como nitrogênio, fósforo e potássio. A compostagem é o processo de transformação biológica de materiais orgânicos, de origem vegetal em fertilizantes utilizáveis na agricultura. Esse processo garante que parte do material seja mineralizado, o que disponibiliza os elementos essenciais e parte do material fique humificado. Bons resultados no processo de estabilização da matéria orgânica tem sido encontrados com a vermicompostagem, por exemplo (Dores-Silva et al., 2013).

O ensino de técnicas de produção orgânica e cultivo doméstico pretende estimular o consumo e a produção de alimentos sadios e de qualidade, e esses conhecimentos podem ser perpetuados para as famílias dos participantes. O Ministério de Desenvolvimento Agrário, junto ao INCRA e FIO CRUZ, buscam estimular a adoção dessas técnicas orgânicas de produção junto à agricultura familiar, para reduzir o uso de defensivos agrícolas e produzir alimentos seguros para a população. Sendo assim, esse é mais um motivo à execução desse projeto.

Sendo assim, o intuito do presente projeto foi envolver os voluntários e a comunidade atendida pela Instituição Obras Assistencial Chico Xavier, em oficinas de arte e educação ambiental. Buscando também a inter-relação entre as áreas para a melhoria da realidade e formação como cidadão.

\section{DESENVOLVIMENTO}

O Bairro Jardim Amanda fica localizado em uma região longínqua do centro da cidade, quase na zona limítrofe da cidade de Itacoatiara. É um bairro populoso e as famílias que habitam são notoriamente carentes, com uma qualidade de vida questionável. As obras Assistenciais Chico Xavier localizada no bairro, oferece atividades à comunidade, como: reforço escolar às crianças, distribuição de alimentos e atenção emocional.

As atividades propostas nesse projeto foram realizadas no período de agosto a dezembro de 2017, no espaço físico da Instituição de caridade. A propriedade da Instituição possuía espaço físico adequado para 
as atividades propostas nesse projeto e é um local conhecido pelo atendimento às pessoas carentes do bairro.

Primeiramente foram providenciadas as necessidades para a instalação de uma horta comunitária: escolha do local, preparação dos canteiros, garrafas PET para delimitar os canteiros, que foram construídos seguindo as formas orgânicas, com inspirações na natureza, em forma de folhas e flores, sendo essa uma característica diferenciada (Figura 1), seguindo depois com a preparação dos substratos e adubação orgânica dos canteiros, tudo com a participação da comunidade e dos discentes do projeto.

As hortas comunitárias têm um papel aglutinador, a participação das pessoas da comunidade em um projeto comum reflete em união, resgate da cultura e de saberes. Por isso, além de olerícolas tradicionais, como tomate, couve, coentro, cebolinha, chicória, manjericão e alface, foram inseridas no contexto da horta, plantas medicinais comumente utilizadas pela população como corama (Bryophylum pinnatum (Lam.) Oken), babosa (Aloe vera), erva-cidreira (Lippia alba Mill. N.E. Br.), mangarataia (Zingiber officinale [Willd.] Roscoe), gengibre amargo (Zingiber zerumbet L. Smith), boldo (Plecthrantuhus barbatus Andr.), óleo elétrico (Piper callosum Ruiz \& Pav) e citronela (Cymbopogon sp.). A utilização de plantas alimentícias locais, também foi considerada e espécies como jambú (Spilanthes acmella (L.) L.), foram propagadas na horta. 0 jambú é classificado como planta alimentícia não convencional e é muito apreciada em pratos regionais, como tacacá, em refogados e em saladas (Kinupp; Lorenzi, 2014).

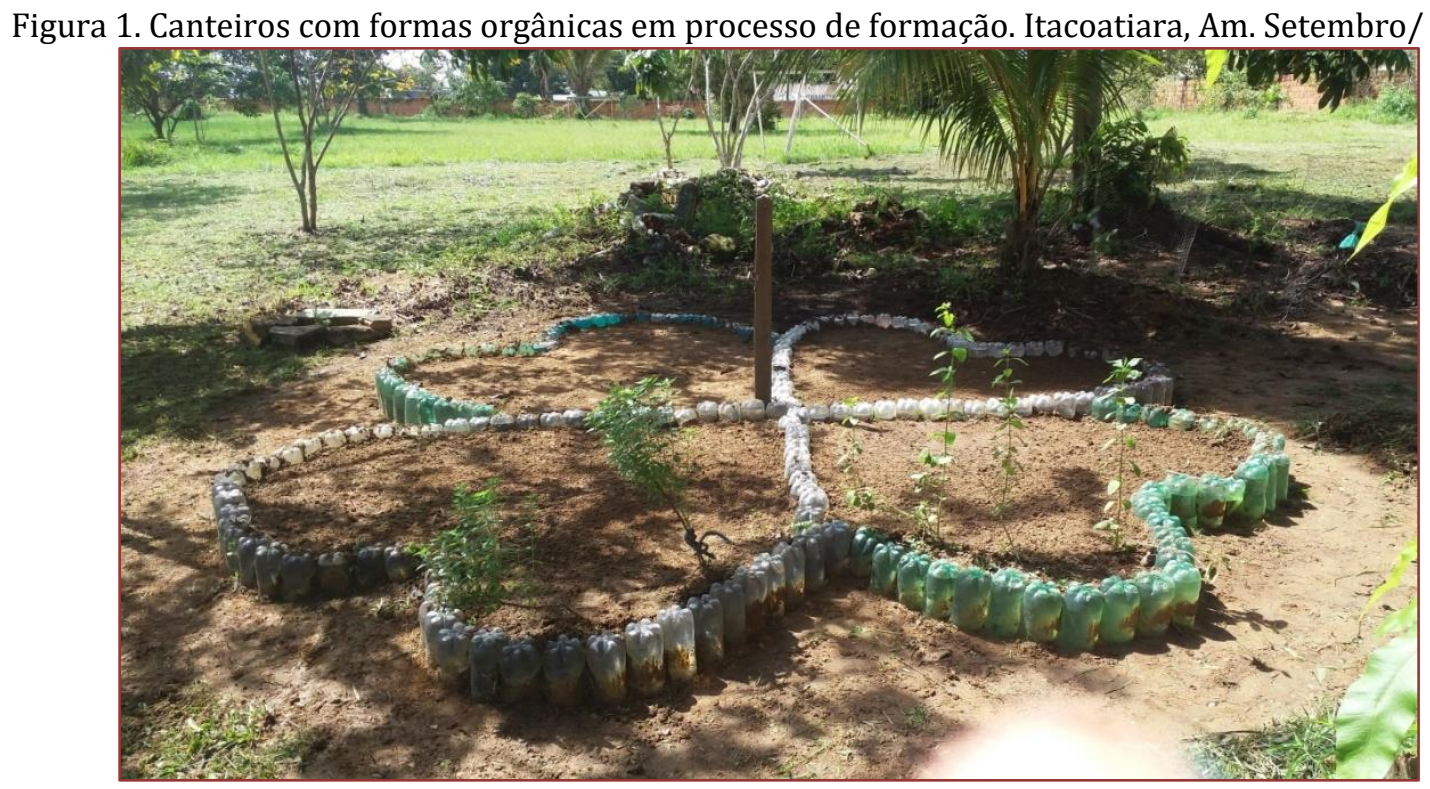

Essas ações incentivam a utilização de materiais de origem nativa ou ocorrente na região e que são adaptados às condições edafo-climáticas locais, apresentam rusticidade e mantém a cultura alimentar. A presença de plantas medicinais na horta estimulou a identificação das espécies pelos participantes, que se sentiram à vontade para explicar que parte era utilizada por suas avós e mães no preparo de remédios naturais e as formas de uso. Esses valores e saberes trocados constituem em uma rica fonte de conhecimento para trabalhos futuros na área de etnobotânica.

Muitas plantas medicinais apresentam alelopatia e podem prevenir/combater o ataque de insetos e/ou microrganismos nas olerícolas da horta. Algumas substâncias têm ação repelente, a exemplo da citronela. Outras podem ter atividade antimicrobiana, sendo de fundamental importância a diversificação de espécies em uma horta, promovendo um ambiente agroecológico e evitando assim o uso de defensivos agrícolas.

Iniciativas que transcendam o ambiente escolar, com a inclusão de pais e comunidade, é o caminho para potencializar as informações e atividades relacionadas à educação ambiental e alimentar e é nesse contexto, que se deve enfatizar sobre a importância da Universidade junto às comunidades levando o conhecimento científico (Morgado, 2006).

As oficinas realizadas seguiram o seguinte cronograma: 
1. Oficinas sobre compostagem doméstica: confecção de compostores alternativos, feitos de garrafas PET para pequenos espaços e compostores comerciais, abordagem dos resíduos domésticos que podem ser utilizados no processo.

2. Preparo do composto orgânico: envolveu os aprendizes nessa atividade pela separação do lixo orgânico doméstico e foi feito o acompanhamento do processo de mineralização da matéria orgânica.

3. Semeadura de olerícolas, produção de mudas e preparo de substrato orgânico. Nessa oficina também foram realizados o transplantio de mudas de plantas medicinais e alimentícias não convencionais, que se propagam de forma vegetativa. As mudas foram oriundas da horta medicinal e aromática do Instituto de Ciências Exatas e Tecnologia, ICET/UFAM.

4. Oficinas sobre aproveitamento de material reciclável: foram utilizadas garrafas PET no preparo de canteiros suspensos para o cultivo de temperos e hortaliças, que podem ser utilizadas em pequenos espaços.

5. Oficinas teórico-práticas em arte, segundo a metodologia da abordagem triangular: os alunos aprenderam sobre a técnica de papietagem. Foram confeccionados vasos decorativos com pinturas em estilo grego.

6. Oficina de preparo de tintas naturais: a partir de plantas foram extraídos pigmentos para a coloração de papéis.

7. Acompanhamento do crescimento das plantas, apoiando-se em conceitos teóricos e práticos e também acompanhamento do processo de compostagem orgânica.

Os encontros semanais foram marcados por palestras teóricas e práticas. As atividades relacionadas à compostagem foram realizadas utilizando garrafas PET e em composteiras comerciais, com o intuito de mostrar diferentes formas de fazer a compostagem. Os discentes também foram orientados a fazer pesquisa sobre hortas, cultivos orgânicos e compostagem, pois, além de aprendizes também puderam exercer atividades de orientação com os participantes.

As oficinas de reciclagem e artísticas foram direcionadas por palestras e ajustes individuais, coordenados pelo bacharel em artes plásticas.

O projeto foi desenvolvido conforme previsto, os encontros foram semanais e na instalação da horta foi necessário mais de um encontro semanal, essa meta foi alcançada com êxito. A instalação de uma horta exige trabalho físico e nem todos apreciam esse trabalho, mas ainda assim todos ajudaram e se dispuseram a preparar os canteiros e o substrato. Assim, os encontros semanais com a comunidade conseguia transcorrer como programado. Os estudantes foram assíduos e proativos. Além de aprendizes também puderam praticar a arte de educar os participantes.

Lared et el. (2011) identificaram cinco fatores interferentes na implementação de um projeto de horta escolar: adesão voluntária das professoras, envolvimento da comunidade escolar, responsável pelo cuidado diário com as plantas, assim como finais de semana e feriados, recursos de materiais e sobrecarga de tarefas. No caso do presente trabalho, poderia ser aplicado à adesão voluntária dos discentes, que já entram no projeto de forma voluntária, havendo a preocupação da continuidade de sua participação até o final das atividades. Houve um pouco de dificuldade para definir um horário que fosse de comum acordo com todos. Logo, foi escolhido o sábado. Ainda assim, alguns estudantes tiveram dificuldades de estar presente em todas as atividades, pois, na Universidade, o sábado é considerado dia letivo e houve a desistência de um estudante no projeto.

Outra dificuldade apontada pelos autores acima e que foi enfrentado nesse projeto foi encontrar um responsável pelo cuidado diário da horta. Esse foi um fator relevante, pois, as plantas são muito exigentes em água no seu crescimento inicial. Na tentativa de minimizar os danos que poderiam ser causados, foi confeccionado um sistema de gotejamento com garrafas PET e 'kits' de soro, seguindo a ideia do grupo do Programa UFBA em Campo, desenvolvido na Atividade Curricular em Comunidade da Universidade Federal da Bahia (UFBA), 2017.

O sistema apresentou alguns problemas, como entupimento da saída de água e consequente proliferação de microalgas. Além disso, a quantidade de água nas garrafas PET era insuficiente para abastecer a horta durante toda a semana. Seria necessário que alguém fizesse a reposição, pelo menos duas vezes durante a semana. 0 sistema tornou-se inviável, mas como estava em início de período chuvoso na região, as plantas conseguiram se estabelecer. 
Figura 2. Processo de confecção de tintas naturais e coloração de papel. Itacoatiara, AM. Outubro de 2017.

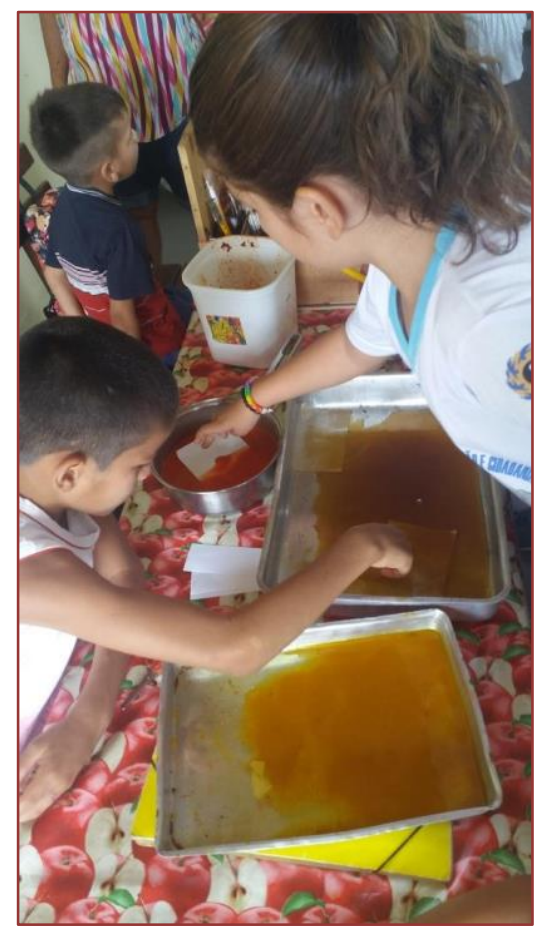

O ensino de arte melhorou a autoestima, despertou e desenvolveu o potencial criativo, possibilitou o desenvolvimento de aspectos cognitivos, sensíveis e culturais. Assim, o ensino de artes articulou os três campos conceituais, o fazer artístico, apreciação e reflexão.

Figura 3. Vasos confeccionados por meio da técnica de papietagem. Itacoatiara, AM. Novembro de 2017.

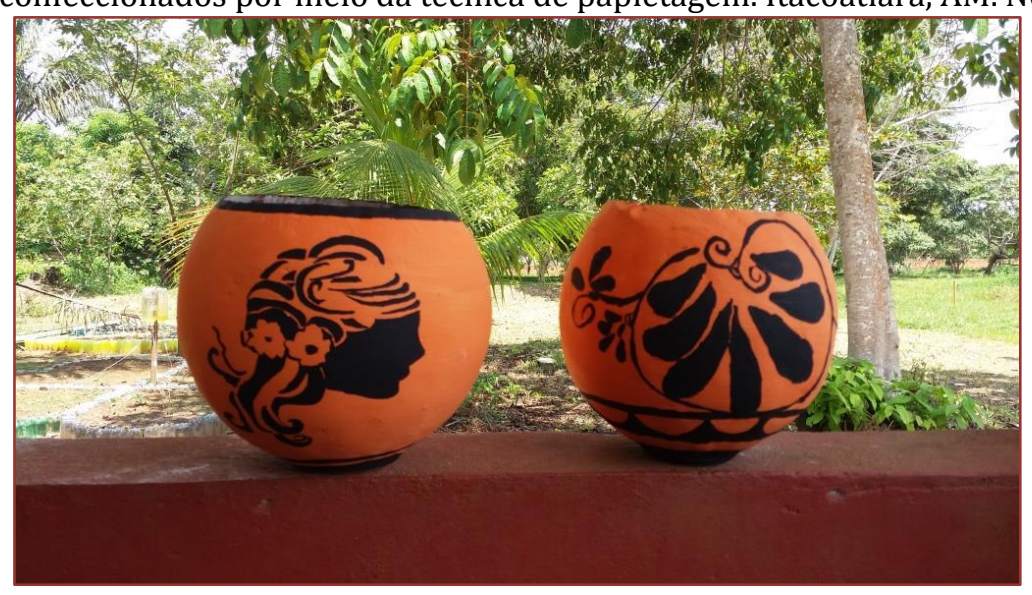

Ao final do trabalho, o público-alvo questionou a coordenação sobre a continuidade do projeto e foi notório o interesse e a satisfação de todos.

\section{CONCLUSÕES}

As ações propostas nesse projeto promoveram a interdisciplinaridade na formação de cidadãos que vivem nesta comunidade carente, em Itacoatiara, Amazonas.

A interdisciplinaridade entre as áreas de artes plásticas e meio-ambiente estimulou a alimentação saudável, através da prática e cultivo na horta, e ampliou suas percepções de mundo através da arte, estimulando assim o aprendizado em outras áreas. 
A produção orgânica realizada poderá se estender até o ambiente doméstico, pois, o cultivo de algumas espécies pode ser feito em pequenos espaços e com reaproveitamento do lixo orgânico de casa.

Foi notório também a aproximação dos estudantes universitários com as comunidades carentes, influenciando dessa forma na sua formação consciente sobre a sociedade.

\section{REFERÊNCIAS}

[1] Parâmetros Curriculares Nacionais: Arte. Secretaria de Educação Fundamental. Brasília: MEC-SEF; 1997

[2] Barbosa, A.M, Cunha F.P.. A abordagem triangular no ensino de artes e culturas visuais. São Paulo: Cortez, 2010.

[3] Coimbra, J. de A. A. Considerações sobre a interdisciplinaridade. Disponível em: http://www.ft.unicamp.br/vitor/processo-seletivo-2014/texto-avila.pdf. Acessado em 25 de abril de 2017.

[4] Kinupp V. F; Lorenzi H; Plantas Alimentícias não convencionais (PANC) no Brasil: guia de identificação, aspectos nutricionais e receitas ilustradas. São Paulo: Instituto Plantarum de Estudos da Flora, 2014.

[5] Lared, V.G.; Thiemann, F. T.; Oliveira, H. T. de; Tullio, A.Di.; Franco, G. M. M. Hortas escolares: desafios e potencialidades de uma atividade de educação ambiental. Educação Ambiental em Ação, n. 36, 2011. Disponível em: https://s3.amazonaws.com/academia.edu.documents/38316249/Iared_et_al_Hortas.pdf?AWSAccessKeyId=AKIAIWO WYYGZ2Y53UL3A\&Expires=1522441277\&Signature=vvY\%2F\%2FMdo4\%2BZboRILdmKJsVTP6E0\%3D\&responseco ntentdisposition=inline\%3B\%20filename\%3dhortas_Escolares_Desafios_E_Potencialida.pdf. Acessado em: 30 de março de 2018.

[6] Morais, L. P. S.; Cunha, B. de D.; Alves, A. C.; Bueno, V. R.; Matsuo, E.; Ferreira, S. da C. Plantas Medicinais: semeando conhecimento, colhendo cidadania. Congreso LXV Congresso Nacional de Botânica XXXIV Erbot - Encontro Regional de Botânicos - MG, BA, ES. Botânica na América Latina: conhecimento, interação e difusão, Bahia: Salvador, 2014.

[7] Morgado, F. da S. A horta escolar na educação ambiental e alimentar: experiência do Projeto Horta Viva nas escolas municipais de Florianópolis. Relatório de conclusão de graduação apresentado ao Curso de Agronomia da Universidade Federal de Santa Catarina, para obtenção do título de Engenheira Agrônoma. 2006.

[8] Mousinho, M.B.da; Araújo, J.S.; Reis, K. J. B. Produção de Horta Escolar com alunos de Ensino Fundamental da Escola Municipal Getúlio Vargas, Floriano, PI. Congreso LXV Congresso Nacional de Botânica XXXIV Erbot - Encontro Regional de Botânicos - MG, BA, ES. Botânica na América Latina: conhecimento, interação e difusão, Bahia: Salvador, 2014.

[9] Santos, C.A. dos; Lima, R. A. Construção de uma Horta Suspensa para o Ensino de Botânica em uma Escola Pública em Porto Velho - RO. Congreso LXV Congresso Nacional de Botânica XXXIV ERBOT - Encontro Regional de Botânicos - MG, BA, ES. Botânica na América Latina: conhecimento, interação e difusão, Bahia: Salvador, 2014.

[10] Santos, C.F. dos; COSTA, F.das C. R. da; Silva, D. dos S. R. da; Albino, A. M.; Lima, R. A. Restauração da Horta na Escola: Vivenciando a Prática no Ensino de Ciências em uma Escola Pública em Porto Velho - RO. Congreso LXV Congresso Nacional de Botânica XXXIV Erbot - Encontro Regional de Botânicos - MG, BA, ES. Botânica na América Latina: conhecimento, interação e difusão, Bahia: Salvador, 2014.

[11] Sediyama, M. A. N.; Santos, I.C.dos; Lima, P.C. de Cultivo Orgânico de Hortaliças. Revista Ceres, Viçosa, v.61, p.829-837, 2014.

[12] Sistema DE Gotejamento EM Garrafas Pet. Disponível em: http://www.ecodesenvolvimento.org/voceecod/faca-voce-mesmo-sistema-de-gotejamento-com-garrafa. Acessado em: 26 de agosto de 2017. 


\section{Capítulo 20}

Análise dos fragmentos florestais remanescentes em uma paisagem com cultivo de dendê, na bacia hidrográfica do Rio Moju - Amazônia

\section{Thais Gleice Martins Braga \\ João Ubiratan Moreira dos Santos \\ Maria de Nazaré Martins Maciel \\ Paula Fernanda Viegas Pinheiro \\ Orleno Marques da Silva Junior}

Resumo: As alterações no uso e cobertura do solo causam vários impactos sobre o meioambiente. Uma maneira de caracterizar tais alterações de uso e cobertura da terra é analisando as métricas da paisagem. Este trabalho teve como objetivo caracterizar e analisar, por meio de métricas de paisagem, os fragmentos florestais remanescentes em uma paisagem com cultivo de dendê, na Bacia Hidrográfica do Rio Moju sob a ótica da conservação da biodiversidade local, fazendo um comparativo entre os anos de 2005 e 2017. A paisagem analisada encontra-se bastante fragmentada, caracterizada pela presença de um número elevado de fragmentos pequenos, demonstrando o forte impacto da atividade humana na área. 0 comprometimento ambiental da paisagem da bacia hidrográfica do rio Moju no que tange à integridade ecológica tornou-se notório, uma vez que mais de $50 \%$ da sua área de vegetação densa com até 50 ha é constituída de ambiente de borda, fator que afeta significativamente a qualidade dos ecossistemas ali existentes. Considerando o contexto em que se encontra a bacia hidrográfica do rio Moju, fazem-se necessárias medidas de planejamento estratégico vinculado à gestão e manejo deste, para contribuir no processo de recuperação e conservação dos fragmentos remanescentes. 


\section{INTRODUÇÃO}

Conforme apontado pelo Núcleo de Assuntos Estratégicos da Presidência da República (2004), o país apresenta enorme potencial para a expansão da produção do dendê, já que conta com cerca de 70 milhões de hectares considerados aptos para o plantio desta oleaginosa, dos quais cerca de $40 \%$ teriam alta aptidão (NAE, 2004). Ou seja, estas áreas aptas ao plantio do dendê superam as áreas disponíveis nos principais países produtores - Indonésia e Malásia - que possuem apenas $617 \mathrm{mil} \mathrm{km}^{2}$ e $110 \mathrm{mil} \mathrm{km}{ }^{2}$, respectivamente.

Nas décadas de 1980 e 1990, a cadeia do biodiesel se consolida no Pará, sendo considerado prioritário para o desenvolvimento econômico regional (HOMMA, 2010). Com o crescimento do mercado de alimentos e o lançamento dos programas brasileiros de Agroenergia e Biodiesel em 2004 e 2010, instalase um novo ciclo econômico no setor agrícola do Pará denominado de "fronteira agrícola da bioenergia" (NAHUM; SANTOS, 2015).

Para a perda da biodiversidade e o desmatamento de florestas intactas - ao invés do plantio em áreas degradadas - como sendo possíveis impactos ambientais da expansão do dendê na Amazônia. Sendo assim, Daronco et al. (2012) sugere que diversas transformações estão ocorrendo nos biomas amazônico, devido a necessidade de produção e desenvolvimento, como é o caso da consolidação da produção da cultura do Dendê.

Esta fragmentação florestal, resultante do processo de substituição da cobertura vegetal por áreas de uso antrópico, é a principal causa da perda da biodiversidade, uma vez que contribui para a extinção de espécies (DARONCO et al., 2012).

Embora esse processo de fragmentação vegetal seja um processo natural, tem se agravado devido as ações antrópicas, de forma que o uso da cobertura vegetal em bacias hidrográficas resulta em processos de perda e fragmentação de habitats, o que altera os processos biológicos e fragiliza o ecossistema, resultando na perda de biodiversidade (REZENDE et al., 2011).

A fragmentação também altera as relações ecológicas entre as espécies vegetais e interfere diretamente na conservação da biodiversidade florística. Bem como interfere diretamente no processo de dispersão e polinização, afetando consequentemente, as comunidades vegetais dependentes dos vetores locais (HANSKI, 2011). Além disso, diminui a troca de material genético, o que aumenta a possibilidade de extinção das espécies vegetais.

Uma forma de mitigar tal processo de impacto na vegetação e garantir a proteção da biodiversidade, bem como dos ecossistemas é por meio da viabilização de áreas protegidas, áreas de preservação permanentes, conectadas, quando possível, através de corredores ecológicos, para reduzir o isolamento destas áreas de preservação, e manter a biodiversidade local (MUCHAILH et al., 2010). Portanto, segundo Muchailh et al. (2010), a análise da cobertura vegetal, direcionada para distribuição espacial dos remanescentes florestais, é uma importante ferramenta que subsidiam propostas que pretendem reduzir os impactos provenientes deste processo de fragmentação de habitats.

Alves et al. (2014) afirma que o Pará é o maior produtor de óleo de palma do Brasil, sendo que a maior parte desta produção é direcionada para as indústrias alimentícias e de cosméticos (DURÃES, 2011). Isto significa que a cadeia do biodiesel ainda não está totalmente implantada no Estado do Pará, mas há a perspectiva de que a dendeicultura avance na região nos próximos anos.

Decorridos cerca de dez anos desde a criação da política da dendeicultura na região, estudos têm evidenciado alguns riscos da expansão desses cultivos, tais como o uso de remanescentes florestais (LEES et al., 2015), a contaminação dos rios e do solo por agrotóxicos (BRANDÃO; SCHONEVELF, 2015), a desapropriação das populações tradicionais (NAHUM; MALCHER, 2012), a legitimação do uso da terra pelo setor agroindustrial do óleo de palma (green grabbing) (BACKHOUSE, 2013), a insegurança alimentar e o empobrecimento da biodiversidade (ALMEIDA, 2015).

Na Amazônia, os estudos de modelagem têm sido utilizados nas avaliações das mudanças de uso da terra relacionadas à intensificação do desmatamento, à expansão agrícola (BRONDIZIO; MORAN, 2012), à urbanização (ZHANG; SETO, 2011); à ocorrência de queimada, aos arranjos institucionais de áreas indígenas e de conservação (ROCHA, 2014) e às mudanças climáticas (SOUSA; ROCHA, 2014). 0 programa internacional Land Use and Cover Change (LUCC) tem contribuído significativamente na consolidação de tal temática (BRONDIZIO, 2014).

Desta forma, a referida pesquisa é de fundamental importância para evidenciar através do estudo dos fragmentos florestais remanescentes em região de bacias hidrográficas com áreas de consolidação do 
Dendê, pois evidenciará dados inéditos relacionados ao comportamento do desflorestamento na área de estudo, mapeará a dinâmica de alterações na paisagem com cultivo do dendê com base nas transições, permanências e vulnerabilidades das classes de vegetação, representará por meio do mapeamento a distribuição espacial dos remanescentes florestais gerados pela fragmentação de uma paisagem com cultivo de dendê na bacia hidrográfica do rio Moju, e indicará áreas com maior potencial de conectividade entre os fragmentos na bacia hidrográfica do rio Moju para formação de corredores ecológicos e manutenção da biodiversidade.

O objetivo deste trabalho é caracterizar e analisar, por meio de métricas de paisagem, os fragmentos florestais remanescentes em uma paisagem com cultivo de dendê, na Bacia Hidrográfica do Rio Moju sob a ótica da conservação da biodiversidade local, fazendo um comparativo entre os anos de 2005 e 2017.

\section{METODOLOGIA}

\section{1 ÁREA DE ESTUDO}

A bacia do rio Moju apresenta extensão territorial de 15.662,097 km² é constituída predominantemente pelo município de Moju, estar presente a montante os municipais de Breu Branco e Jacundá. Segundo Freitas e Silveira (2012) a referida bacia hidrográfica é $4^{\mathrm{a}}$ ordem, apresenta forma geométrica alongada, o que favorece a ação da drenagem sobre o relevo, sendo dividida da seguinte forma, Baixo Moju (BMj), Médio Moju (MMj) e Alto Moju (AMj).

\subsection{DELIMITAÇÃO DA BACIA HIDROGRÁFICA DO RIO MOJU-PA}

A delimitação da área da bacia hidrográfica foi efetuada utilizando-se o arquivo digital em formato shapefile da base hidrográfica ortocodificada disponibilizado pela Agência Nacional da Águas - ANA. Baseada em dados georreferenciados do relevo da área em questão, derivados de produtos SRTM, por meio da utilização da ferramenta Hidrology, pertencente ao programa ArcGis 10.2.

\subsection{PROCESSAMENTO DIGITAL DE IMAGEM}

0 trabalho teve início com o levantamento e aquisição dos dados e informações sobre as áreas da bacia hidrográfica do rio Moju, sucessivamente foi feito a seleção de imagens de satélite dos sensores Landsat 5 e 8, nos anos de 2005 e 2017, além das imagens, utilizou-se mapas básicos e topográficos de escalas e temas distintos para subsidiar o estudo. Toda a base planialtimétrica utilizada foi computada por meio de cartas topográficas do IBGE.

O processamento digital e as análises das imagens utilizadas, foram efetuados nos softwares Envi e ArcGis, disponíveis no Laboratório de Sensoriamento Remoto e Geoprocessamento da Universidade Federal Rural da Amazônia - UFRA, onde foram armazenados no sistema informações geográficas de todos os dados presentes nas imagens de satélite (VENTURIERI, 2011).

O banco de dados foi criado a partir das imagens de satélite, dos anos de 2005 e 2017 foram processadas, bem como analisadas por etapas distintas, de maneira que foram geradas todas as informações referentes à cobertura vegetal e fragmentação remanescentes, levando em consideração as mudanças históricas ocorridas na área de estudo relacionados a cobertura vegetal a partir da expansão da monocultura do dendê na bacia hidrográfica do rio Moju. Permitindo obter informações como a quantificação de áreas das classes temáticas e a dinâmica da cobertura vegetal e dos fragmentos remanescentes após a consolidação da área de cultivo.

\subsection{ANÁLISE DOS DADOS}

A configuração da paisagem e dos fragmentos de vegetação remanescente foram analisados utilizando-se a extensão Patch Analyst do software ARCGIS 10.2. Segundo Almeida et al. (2011), este programa é frequentemente utilizado para análises do padrão espacial, como suporte para o estudo da conservação da biodiversidade e manejo florestal, uma vez que possibilita calcular diversas métricas em nível de mancha (patch), classe (class) e paisagem (landscape). 
Através desta ferramenta foi possível analisar descritivamente as inúmeras métricas que quantificam a composição e/ou a configuração da paisagem, que afetam de forma significativa os processos ecológicos, tanto independente, quanto simultaneamente, da biodiversidade da flora da bacia hidrográfica do rio Moju. As métricas referente aos fragmentos de vegetação remanescentes analisadas no presente estudo são as seguintes:

Quadro 1: Variáveis métricas que quantificam a composição e/ou a configuração da paisagem referente aos fragmentos de vegetação remanescentes.

\begin{tabular}{|c|c|c|c|}
\hline $\begin{array}{l}\text { Tipo de } \\
\text { Métrica }\end{array}$ & Métrica & Unidade & Descrição \\
\hline \multirow{5}{*}{$\begin{array}{l}\text { Índice de } \\
\text { Forma }\end{array}$} & AWMSI & Adimensional & $\begin{array}{l}\text { Relação entre os perímetros dos fragmentos, circularidade e } \\
\text { o número de fragmentos, ponderado pela área. }\end{array}$ \\
\hline & MSI & Adimensional & $\begin{array}{l}\text { Relação entre os perímetros dos fragmentos, circularidade e } \\
\text { o número de fragmentos. }\end{array}$ \\
\hline & MPAR & $\mathrm{m} / \mathrm{ha}$ & $\begin{array}{l}\text { Somatório da razão perímetro/área divido pelo número de } \\
\text { fragmentos. }\end{array}$ \\
\hline & MPFD & Adimensional & $\begin{array}{l}\text { Valores próximos de } 1 \text { indicam formas regulares e próximos } \\
\text { a } 2 \text { aumento na complexidade. }\end{array}$ \\
\hline & AWMPFD & Adimensional & $\begin{array}{l}\text { Valores próximos de } 1 \text { indicam formas regulares e próximos } \\
\text { a } 2 \text { aumento na complexidade, ponderados pela área. }\end{array}$ \\
\hline \multirow{3}{*}{$\begin{array}{l}\text { Índices de } \\
\text { Borda }\end{array}$} & TE & $\mathrm{m}$ & Total de borda (perímetro) dos fragmentos. \\
\hline & ED & $\mathrm{m} / \mathrm{ha}$ & Quantidade de borda relativa à área da paisagem. \\
\hline & MPE & $\mathrm{m} /$ fragmento & Média da quantidade borda por fragmento. \\
\hline \multirow{5}{*}{$\begin{array}{c}\text { Índices de } \\
\text { Densidade e } \\
\text { tamanho }\end{array}$} & MPS & ha & Tamanho médio dos fragmentos de uma classe. \\
\hline & NumP & Quantidade & Número total de fragmentos de uma classe. \\
\hline & MedPS & ha & Mediana do tamanho do fragmento. \\
\hline & PSCoV & $\%$ & Coeficiente de Variação dos fragmentos. \\
\hline & PSSD & ha & Desvio padrão das áreas dos fragmentos. \\
\hline \multirow{2}{*}{ Índice de Área } & TLA & ha & Somatório das áreas de todos os fragmentos da paisagem. \\
\hline & $\mathrm{CA}$ & ha & Somatório das áreas dos fragmentos de cada classe. \\
\hline
\end{tabular}

Fonte: Junior et al. (2015) 


\section{RESULTADOS E DISCUSSÃO}

\subsection{ANÁLISE ESTATÍSTICA DAS MÉTRICAS REFERENTE AOS FRAGMENTOS DE VEGETAÇÃO REMANESCENTES, NOS ANOS 2005 E 2017, APÓS A EXPANSÃO DA MONOCULTURA DO DENDÊ NA BACIA HIDROGRÁFICA DO RIO MOJU.}

Quanto à forma (tabela 1) da paisagem da bacia hidrográfica do rio Moju, o índice de forma (MSI) foi 2,8 em 2005 e aumentou para 3.0 em 2017, ou seja foi mais regular em 2005 para áreas de até 50 hectares. Para áreas com 250 a 500 hectares, as formas se mostraram mais regulares em 2017 com MSI igual a 11.2. Na análise ponderada AWMSI, esse padrão se manteve, mesmo com a distribuição de pesos de acordo com o tamanho das áreas, diferenciando apenas para áreas com até 50ha, onde o índice de forma média ponderada pela área (AWMSI) aponta que em 2005 o índice foi de 4.4 e em 2017 aumentou para 4.7, o que tornou a forma da área mais irregular. No geral, tanto para MSI como para AWMSI, as áreas entre $1000 \mathrm{e}$ 2000 ha apresentaram formas mais irregulares, enquanto que áreas com até 50ha apresentaram formas mais regulares.

Quanto ao tamanho médio das manchas, verifica-se que para áreas com até 50ha, o Índice Médio do Perímetro pela Área (MPAR) para os fragmentos foi de 81.4 no ano de 2005 e aumentou para 82.6 no ano 2017, o que significa uma menor relação área interna/área externa, portanto menor relação com os efeitos externos. Na opinião de Silva e Souza (2014), é preciso esclarecer que mesmo apresentando formatos irregulares, os fragmentos maiores estão sob menor efeito de borda que os pequenos efetivamente em função de seu tamanho.

Ainda por meio da visualização da Tabela 1 pode-se verificar a dimensão fractal (MPFD) encontrada em torno de 1,31 para áreas com até 50ha, tanto no ano 2005 como em 2017, denotando que tais fragmentos apresentam pouca complexidade em suas bordas, tendendo a apresentar formas regulares, o que evidencia a forte presença humana na paisagem do município. Este valor mostra que os fragmentos desta classe possuem uma forma próximo da regular o que teoricamente seria bom, caso sua área não fosse tão reduzida (áreas com até 50ha). Mediante o exposto torna-se importante ressaltar que quanto mais distante o fragmento estiver da forma básica, mais recortado ele se torna, sendo mais propicio ocorrer o efeito de borda na paisagem. Na análise ponderada AWMPFD, esse padrão se manteve, mesmo com a distribuição de pesos de acordo com o tamanho das áreas.

Em síntese, em relação à complexidade (AWMSI, MSI, MPAR, MPFD e AWMPFD) da formação florestal foi possível constatar que a bacia hidrográfica do rio Moju apresentou os menores valores para áreas com até 50ha (Tabela 2), exceto no caso do MPAR, onde classes de menores hectares apresentaram os valores mais elevados, ou seja, as classes de menor hectare possuem maior regularidade em suas formas, devido a menor relação área interna/área externa. Isso pode indicar menor acesso oriundo de seu entorno e um efeito de borda menos intenso para áreas menores.

Tabela 1: Teste para comparação de médias das métricas referente aos fragmentos de vegetação remanescentes, nos anos 2005 e 2017, após a expansão da monocultura do dendê na bacia hidrográfica do rio Moju.

\begin{tabular}{|c|c|c|c|c|c|c|c|c|c|c|}
\hline \multirow{2}{*}{ Classes / Métrica / Ano } & \multicolumn{2}{|c|}{ AWMSI } & \multicolumn{2}{|c|}{ MSI } & \multicolumn{2}{|c|}{ MPAR } & \multicolumn{2}{|c|}{ MPFD } & \multicolumn{2}{|c|}{ AWMPFD } \\
\hline & 2005 & 2017 & 2005 & 2017 & 2005 & 2017 & 2005 & 2017 & 2005 & 2017 \\
\hline Até 50ha & 4.37 & 4.70 & 2.79 & 3.0 & 81.39 & 82.6 & 1.31 & 1.3 & 1.33 & 1.3 \\
\hline 50 a 100ha & 7.63 & 8.10 & 7.83 & 8.4 & 33.57 & 33.9 & 1.36 & 1.4 & 1.35 & 1.4 \\
\hline 100 a 250 ha & 11.60 & 10.39 & 11.03 & 10.2 & 34.51 & 26.7 & 1.39 & 1.4 & 1.39 & 1.4 \\
\hline 250 a 500ha & 20.40 & 11.15 & 20.40 & 11.2 & 37.12 & 22.1 & 1.43 & 1.4 & 1.43 & 1.4 \\
\hline 500 a 1000 ha & 21.58 & 0.00 & 21.58 & 0.00 & 33.27 & 0.00 & 1.43 & 0.00 & 1.43 & 0.00 \\
\hline 1000 a 2000 ha & 31.00 & 0.00 & 31.00 & 0.00 & 25.80 & 0.00 & 1.44 & 0.00 & 1.44 & 0.00 \\
\hline$>2000 \mathrm{ha}$ & 29.52 & 29.49 & 29.52 & 29.5 & 18.29 & 20.0 & 1.42 & 1.4 & 1.42 & 1.4 \\
\hline
\end{tabular}


Figura 1: Boxplot para comparação de médias das métricas referente aos fragmentos de vegetação remanescentes, nos anos 2005 e 2017, após a expansão da monocultura do dendê na bacia hidrográfica do rio Moju.
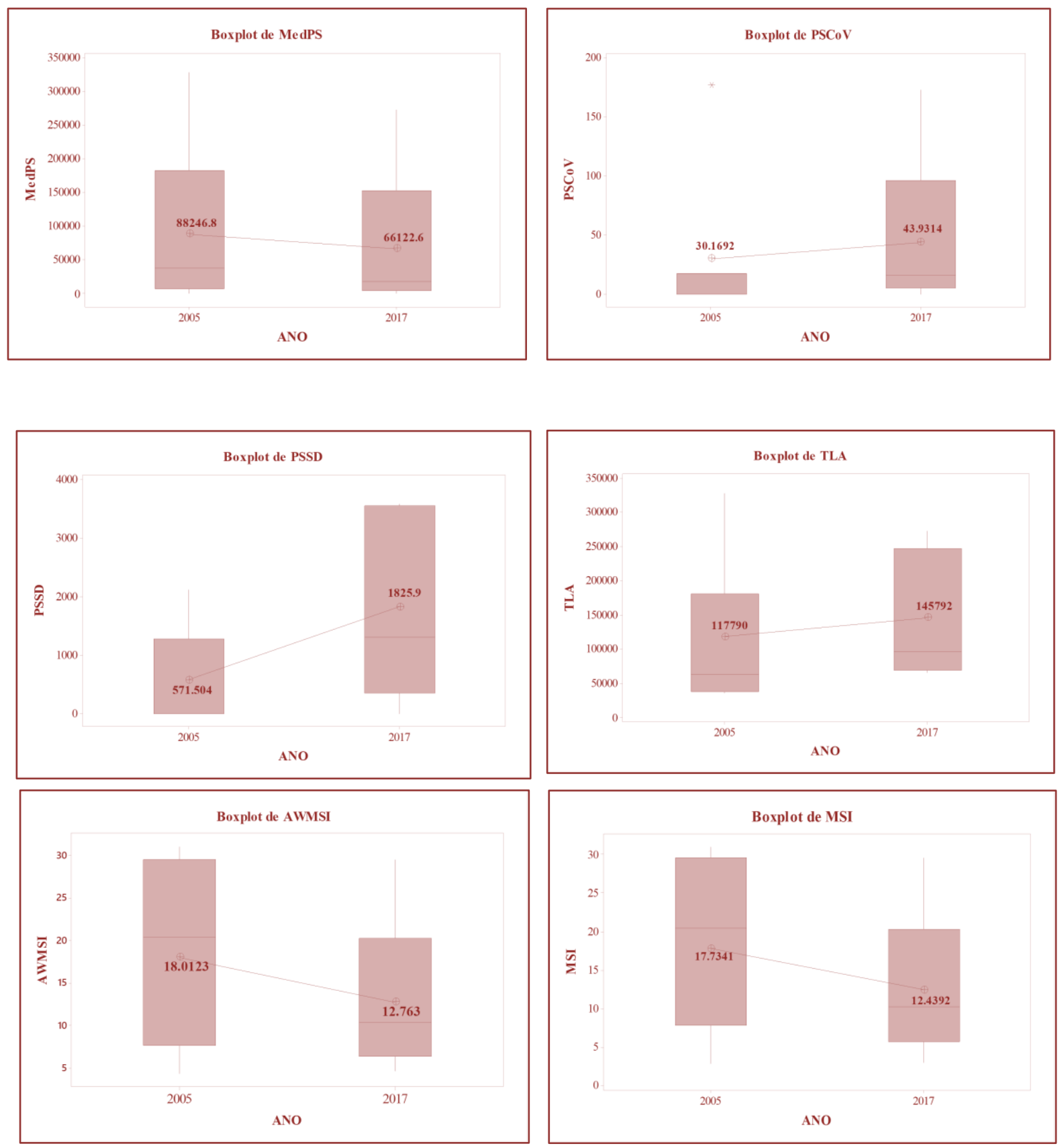

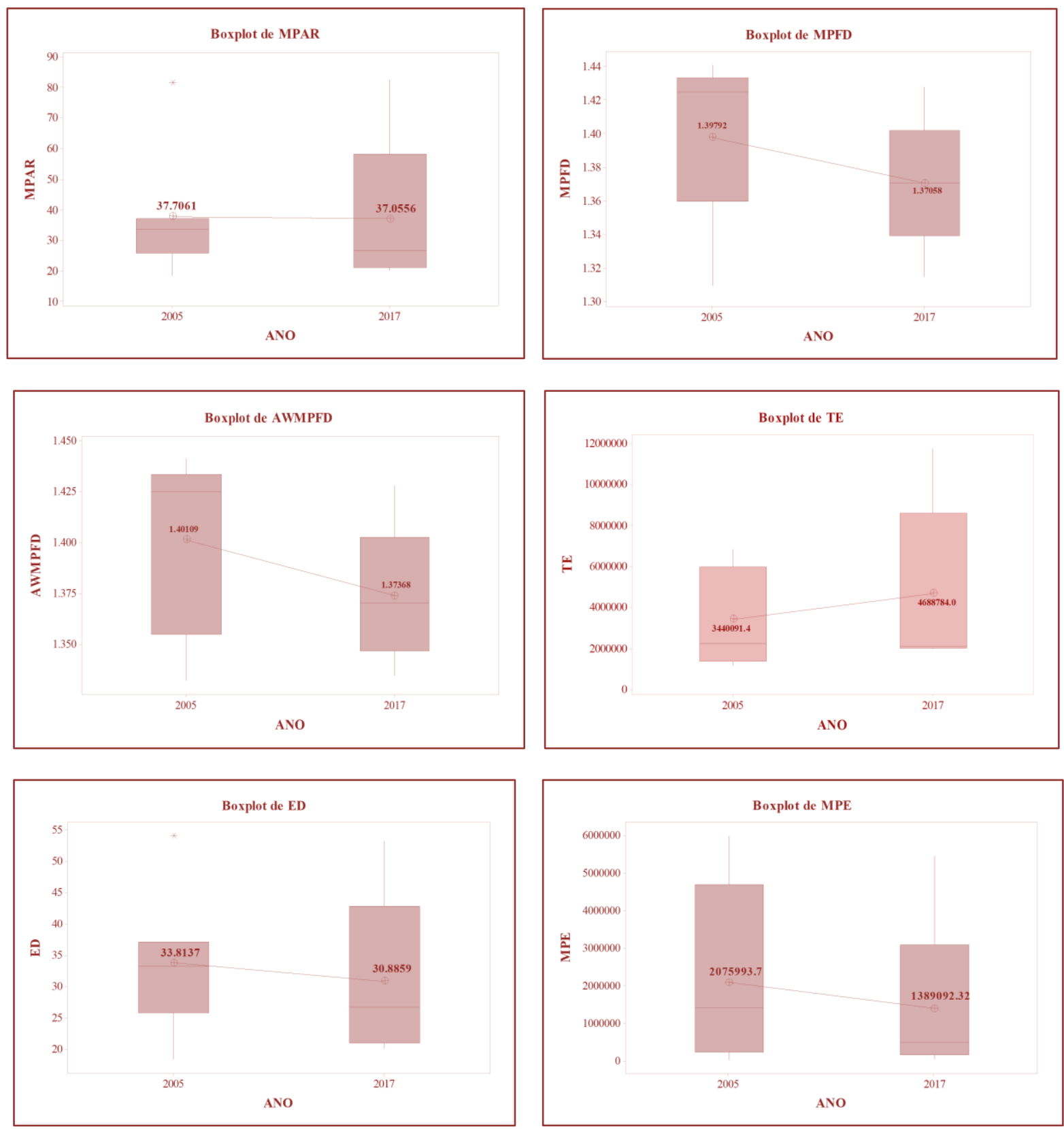
Na tabela 2, verifica-se que as bordas dos fragmentos (TE) para todos os tamanhos de áreas apresentaram aumento em 2017, se comparado com o ano de 2005, com exceção das áreas com 100 a 250 ha que em 2005 tinha $2.230,86 \mathrm{~km}^{2}$ e reduziu para $1.972,74 \mathrm{~km}^{2}$, o que enfatiza o elevado grau de fragmentação na paisagem em 2005, pois quanto maior for o total de margens, maior a fragmentação da paisagem, assim sendo a quantidade total de margens é um excelente indicador da configuração da paisagem. A importância das margens é muito relevante, pois há uma importante interação da flora e da fauna nestas áreas de margem, que podem constituir habitats por si só, além de serem claramente frentes de interface: predação e refúgio, dispersão de sementes e re-colonização, proteção do vento, etc. (HOLANDA et al., 2010).

Segundo Pires (1995), a forma dos fragmentos florestais é um importante parâmetro a ser considerado, pois está diretamente relacionado ao efeito de borda, determinando o grau com que esse efeito age sobre o fragmento e a maior ou menor influência dos fatores externos sobre a sua biodiversidade.

A densidade das bordas de áreas com até 50ha apresentou redução, visto que em 2005 a densidade foi de $54.1 \mathrm{~m} /$ ha e em 2017 foi de $53.4 \mathrm{~m} /$ ha. Ressalta-se que quanto maior o valor de densidade da borda, maior é o efeito da borda, portanto maléfica. A redução da densidade de borda (ED), para a maioria das classes, também comprova a redução da fragmentação florestal no intervalo de tempo avaliado (2005 a 2017).

Quanto maior o número de fragmento de determinada classe, maior a densidade de borda (comprimento total de borda por hectare). Assim, é natural entender que, quanto maior esse valor, maior a fragmentação da paisagem. Aumento da densidade de borda também foi observado por Tonial (2003), o qual citou valores de 55,7; 50,0; 56,0; e 57,2 m/ha nos anos de 1984, 1989, 1994 e 1999, respectivamente.

Na região Centro-Leste do Pará, Pereira et al. (2001) observaram crescimento significativo da densidade de borda de 1973 para 1997, passando de 3 para $25 \mathrm{~m} /$ ha para a paisagem (classes floresta, pasto e capoeira), o que atribuíram ao aumento do número de fragmentos. 0 aumento da densidade de bordas da classe floresta implicou maior degradação desse ambiente, associada aos maléficos efeitos de borda.

O comprimento médio das bordas (Média do Comprimento da Borda - MPE) apresentou aumento na maioria das classes, exceto para a classe de 250 a 500ha que em 2005 tinha $1.408 .020,0 \mathrm{~m}$ e em 2017 reduziu para $709.400,0 \mathrm{~m}$. Da mesma forma ocorreu para a classe maior que 2000ha que reduziu de 5.989.380,0m em 2005 para 5.459.580,0m em 2017.

Para classe com até 50ha, o MPE foi de 18.639,90m em 2005 aumentando para 21.433.60m em 2017. Assim, quanto mais se aproxima da borda, maiores serão os efeitos sentidos no meio biofísico, havendo maior incidência na propagação de espécies invasoras, as quais inibem a regeneração das espécies nativas (ZILLER, 2005). Essa situação se agrava a partir dos usos estabelecidos no entorno dos fragmentos, tais como: pastagens, cultivos, áreas industriais e de extração de minérios, aquicultura, adensamentos urbanos, solos expostos dentre outros.

Tabela 2. Índices de borda da área ocupada por fragmentos de vegetação densa distribuídos por classe de tamanho na paisagem da bacia hidrográfica do rio Moju.

\begin{tabular}{|c|c|c|c|c|c|c|}
\hline \multirow{2}{*}{ Classes / Métrica / Ano } & \multicolumn{2}{|c|}{$\mathrm{TE}\left(\mathrm{km}^{2}\right)$} & \multicolumn{2}{|c|}{$\mathrm{ED}(\mathrm{m} / \mathrm{ha})$} & \multicolumn{2}{|c|}{ MPE (m/fragmento) } \\
\hline & 2005 & 2017 & 2005 & 2017 & 2005 & 2017 \\
\hline Até 50ha & $6.859,50$ & $11.788,50$ & 54.1 & 53.4 & $18.639,9$ & $21.433,6$ \\
\hline 50 a 100ha & $1.153,92$ & $2.094,90$ & 32.3 & 32.3 & $230.784,0$ & $261.863,0$ \\
\hline 100 a 250 ha & $2.230,86$ & $1.972,74$ & 35.8 & 26.7 & $446.172,0$ & $493.185,0$ \\
\hline 250 a 500 ha & $1.408,02$ & $2.128,20$ & 37.1 & 22.0 & $1.408 .020,0$ & $709.400,0$ \\
\hline 500 a $1000 \mathrm{ha}$ & $1.758,78$ & 0.00 & 33.3 & 0.0 & $1.758 .780,0$ & 0.00 \\
\hline 1000 a $2000 \mathrm{ha}$ & $4.680,18$ & 0.00 & 25.8 & 0.0 & $4.680 .180,0$ & 0.00 \\
\hline$>2000$ ha & $5.989,38$ & $5.459,58$ & 18.3 & 20.0 & $5.989 .380,0$ & $5.459 .580,0$ \\
\hline
\end{tabular}

Na tabela 3 também é possível verificar a distribuição da área ocupada pelos fragmentos. A subdivisão dos fragmentos por classes de tamanhos possibilitou uma análise estrutural mais pontual para cada tipologia de classes, tendo em vista a diversidade de tamanhos dos fragmentos (Tabela 3 e Figura 2H e 2I).

Os dois maiores fragmentos da paisagem (área maior que 181.423,0 km²) pertencem á classes de 1000 a 2000ha e maior que 2000ha. Estes fragmentos da bacia encontram-se nas áreas menos povoadas, evidenciada pelo menor número de localidades e vilarejos, o que em consequência acarreta um menor 
impacto ambiental. Eles representam aproximadamente $61.7 \%$ da área de vegetação densa em 2005, ou seja, da matriz da paisagem.

Em geral, os maiores fragmentos possuem maior biodiversidade, uma vez que possibilitam espacialmente o desenvolvimento e perpetuação das espécies. Assim, quanto maior o fragmento, maior a possibilidade do desenvolvimento de populações mais complexas e plurais (EWERS \& DIDHAM, 2006).

Pode-se observar que grande parte dos fragmentos de tipologia florestal está localizada junto aos recursos hídricos, por isso apresenta formas mais alongadas, formando corredores denominados de mata ciliar (Figura 2C).

Verifica-se na tabela 3 que todas as classes de fragmentos apresentaram aumento das áreas ocupadas, exceto a classe maior que 2000 ha. Apesar disto, esses fragmentos são importantes e devem ser conservados, pois auxiliam na conexão entre os fragmentos maiores, pois de acordo com Metzger (2003), os fragmentos com área superior a 0,72 ha têm condições de assumir uma importante função na conexão florestal, pois são úteis à locomoção de animais e dispersão de sementes na paisagem.

O número de fragmentos das classes com até 50ha aumentou de 368 em 2005 para 550 em 2017, bem como a área dos fragmentos $\left(\mathrm{km}^{2}\right)$ que em 2005 era de $12.6715,0 \mathrm{~km}^{2}$ aumentando para $220.729,0 \mathrm{~km}^{2}$. Em 2005, a área dos fragmentos com até 50ha representava $15.4 \%$ do total da vegetação densa e aumentou para $30.3 \%$ em 2017, um aumento de $97 \%$ na área dos fragmentos.

Nas classes com 50 a 100ha, o número de fragmentos aumentou de 5 em 2005 para 8 em 2017, bem como a área dos fragmentos $\left(\mathrm{km}^{2}\right)$ que em 2005 era de $35.708,5 \mathrm{~km}^{2}$ aumentando para $64.870,7 \mathrm{~km}^{2}$. Em 2005, a área dos fragmentos representava $4.3 \%$ do total da vegetação densa e aumentou para $8.9 \%$ em 2017, um aumento de $105.5 \%$ na área dos fragmentos.

Para classes com mais de 2000 ha, o número de fragmentos não sofreu alterações, contudo a área dos fragmentos $\left(\mathrm{km}^{2}\right)$ sofreu redução, visto que em 2005 era de $327.523,0 \mathrm{~km}^{2}$ diminuindo para $272.733,0$ $\mathrm{km}^{2}$. Desta forma, em 2005, a área dos fragmentos representava $39.7 \%$ do total da vegetação densa e reduziu para $37.4 \%$ em 2017, uma redução de 5.8\% na área dos fragmentos.

Tabela 3. Área ocupada por fragmentos de vegetação densa distribuídos por classe de tamanho na paisagem da bacia hidrográfica do rio Moju.

\begin{tabular}{|c|c|c|c|c|c|c|}
\hline \multirow{2}{*}{ Classes / Métrica / Ano } & \multicolumn{2}{c}{ № de fragmentos } & \multicolumn{2}{c|}{ Área de fragmentos $\left(\mathrm{km}^{2}\right)$} & \multicolumn{3}{c|}{ Área dos fragmentos (\%) } \\
\hline Até 50ha & 2005 & 2017 & 2005 & 2017 & 2005 & 2017 \\
\hline 50 a 100ha & 5 & 550 & $126.715,0$ & $220.729,0$ & 15.4 & 30.3 \\
\hline 100 a 250ha & 5 & 4 & $35.708,5$ & $64.870,7$ & 4.3 & 8.9 \\
\hline 250 a 500ha & 1 & 3 & $37.361,2$ & $73.797,5$ & 7.6 & 10.1 \\
\hline 500 a 1000ha & 1 & 0 & $52.868,6$ & 0 & 6.6 & 13.3 \\
\hline 1000 a 2000ha & 1 & 0 & $181.423,0$ & 0 & 22.0 & 0.0 \\
\hline >2000ha & 1 & 1 & $327.523,0$ & $272.733,0$ & 39.7 & 37.4 \\
\hline Total & 382 & 566 & $824.527,4$ & $728.958,9$ & 100.0 & 100.0 \\
\hline
\end{tabular}

Fonte: Dados resultantes da pesquisa (2018).

Para classes menores (com até 250ha), o tamanho médio dos fragmentos (MPS) aumentou. Na paisagem de classe com até 50ha aumentou de 344.34 em 2005 para 401.33 em 2017, bem como a mediana do tamanho do fragmento da classe que em 2005 era de 139ha aumentando para 150ha. Do tamanho médio dos fragmentos, obtiveram-se 327.523 ha (MPS) para paisagem com mais de 2000 ha; o desvio-padrão (PSSD) foi de 327.523 ha e o coeficiente de variação (PSCov), 0\%, visto que há apenas 1 fragmento nesta classe. 0 valor de MPS relaciona-se à variabilidade do tamanho dos fragmentos já apontada no desviopadrão (PSSD) e ao coeficiente de variação (PSCov). 
Tabela 4. Índices de Densidade e tamanho da área ocupada por fragmentos de vegetação densa distribuídos por classe de tamanho na paisagem da bacia hidrográfica do rio Moju.

\begin{tabular}{|c|c|c|c|c|c|c|c|c|}
\hline \multirow{2}{*}{ Classes / Métrica / Ano } & \multicolumn{3}{c}{ MPS (ha) } & \multicolumn{2}{c}{ MedPS (ha) } & \multicolumn{4}{c|}{ PSCoV (\%) } \\
\hline Até 50ha & 2005 & 2017 & 2005 & 2017 & 2005 & 2017 & 2005 & 2017 \\
\hline 50 a 100ha & 744.34 & 401.33 & 139.50 & 150.0 & 176.34 & 173.2 & 607.20 & 695.1 \\
\hline 100 a 250ha & 12472.70 & 8108.84 & 6755.76 & 8180.5 & 17.87 & 16.2 & 1276.19 & 1311.3 \\
\hline 250 a 500ha & 37928.10 & 32276.20 & 37928.10 & 32369.3 & 0.00 & 11.1 & 0.00 & 3583.0 \\
\hline 500 a 1000ha & 52868.60 & 0.00 & 52868.60 & 0.00 & 0.00 & 0.00 & 0.00 & 0.00 \\
\hline 1000 a 2000ha & 181423.00 & 0.00 & 181423.00 & 0.00 & 0.00 & 0.00 & 0.00 & 0.00 \\
\hline >2000ha & 327523.00 & 272733.00 & 327523.00 & 272733.0 & 0.00 & 0.00 & 0.00 & 0.0 \\
\hline
\end{tabular}

Fonte: Dados resultantes da pesquisa (2018).

\subsection{PADRÕES ESPACIAIS DOS FRAGMENTOS DE VEGETAÇÃO DENSA REMANESCENTES, NOS ANOS 2005 E 2017, APÓS A EXPANSÃO DA MONOCULTURA DO DENDÊ NA BACIA HIDROGRÁFICA DO RIO MOJU.}

Os estudos sobre avaliação dos serviços ecológicos não podem ser reduzidos ao impacto em ecossistemas isoladamente, devendo ser considerado efeitos como a fragmentação da paisagem (FRANK et al. 2012). A fragmentação ocasiona consequências sobre o provimento de serviços ambientais, sendo que as métricas de paisagem são as medidas de aspectos estruturais da paisagem inter-relacionando medidas de área, comprimento de borda e distâncias (HARGIS et al. 1998).

Neste contexto, a compreensão espacial da cobertura vegetal apresenta-se como importante ferramenta para a gestão dos recursos naturais e subsídio para estudos referentes a serviços ambientais.

Por meio das figuras 2A e 2B também é possível verificar a distribuição espacial dos fragmentos menores que 50 hectares presentes na bacia hidrográfica do rio Moju. É importante ressaltar que $30.3 \%$ dos fragmentos desta classe apresentam áreas menores que 1 ha, não sendo um bom indicativo para a sustentação e manutenção de muitas espécies de fauna.

Segundo Lima (1997), a ocorrência de aumento e grande quantidade de pequenos fragmentos florestais é comum em paisagens muito antropizadas, como a observada na microrregião do Nordeste do Pará. 0 principal problema deste padrão é que quanto mais área florestada estiver contida em pequenos fragmentos, mais intensamente estão sujeitas ao efeito de borda (RODRIGUES; ADAMI, 2005). Conforme pode ser observado na Tabela 3, para o intervalo de classe entre 250 e 500 ha existia apenas um fragmento de $37.928,1 \mathrm{~km}^{2}$ (figuras $2 \mathrm{~N}$ ) em 2005, o que o caracteriza como de valor médio na conservação da biodiversidade, de acordo com a classificação de Laurence e Vasconcelos (2009).

Dada a capacidade de métricas espaciais para caracterizar a estrutura da paisagem, essas métricas podem ser um instrumento valioso para identificar padrões de crescimento em áreas urbanas e rurais e avaliar possíveis opções de crescimento urbano, com base em características espaciais (AGUILERA; VALENZUELA; BOTEQUILHA-LEITÃO, 2011).

Os efeitos de borda podem ser sentidos até 500 metros adentro da floresta. Todavia, são muito mais notados nos primeiros 35 metros (RODRIGUES, 1998). Percebe-se nas figuras 2D e 2E que vários fragmentos estão totalmente envolvidos pelo efeito de borda, principalmente nas margens do Rio Moju, correndo risco de serem extintas da paisagem caso não sejam constituídas medidas de conectividade florestal, principalmente para reestabelecer as APPs. É possível visualizar nas figuras $2 \mathrm{~F}$ e $2 \mathrm{G}$ que as áreas de vegetação densa diminuíram em detrimento da ampliação de áreas antropizadas e de vegetação secundária. 
Figura 2: Fragmentos da vegetação densa da bacia hidrográfica do rio Moju, por classe de tamanho em hectares (ha).
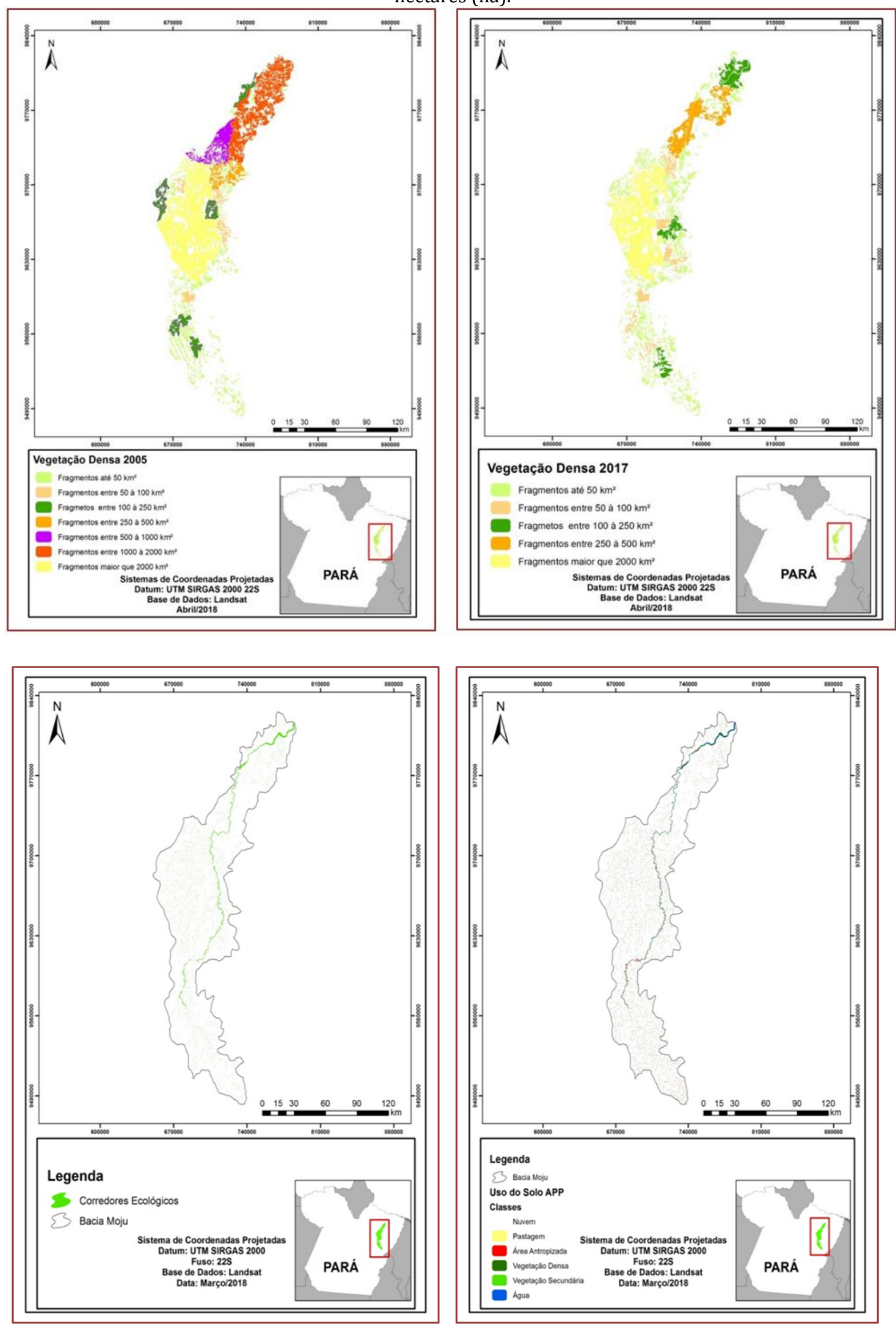

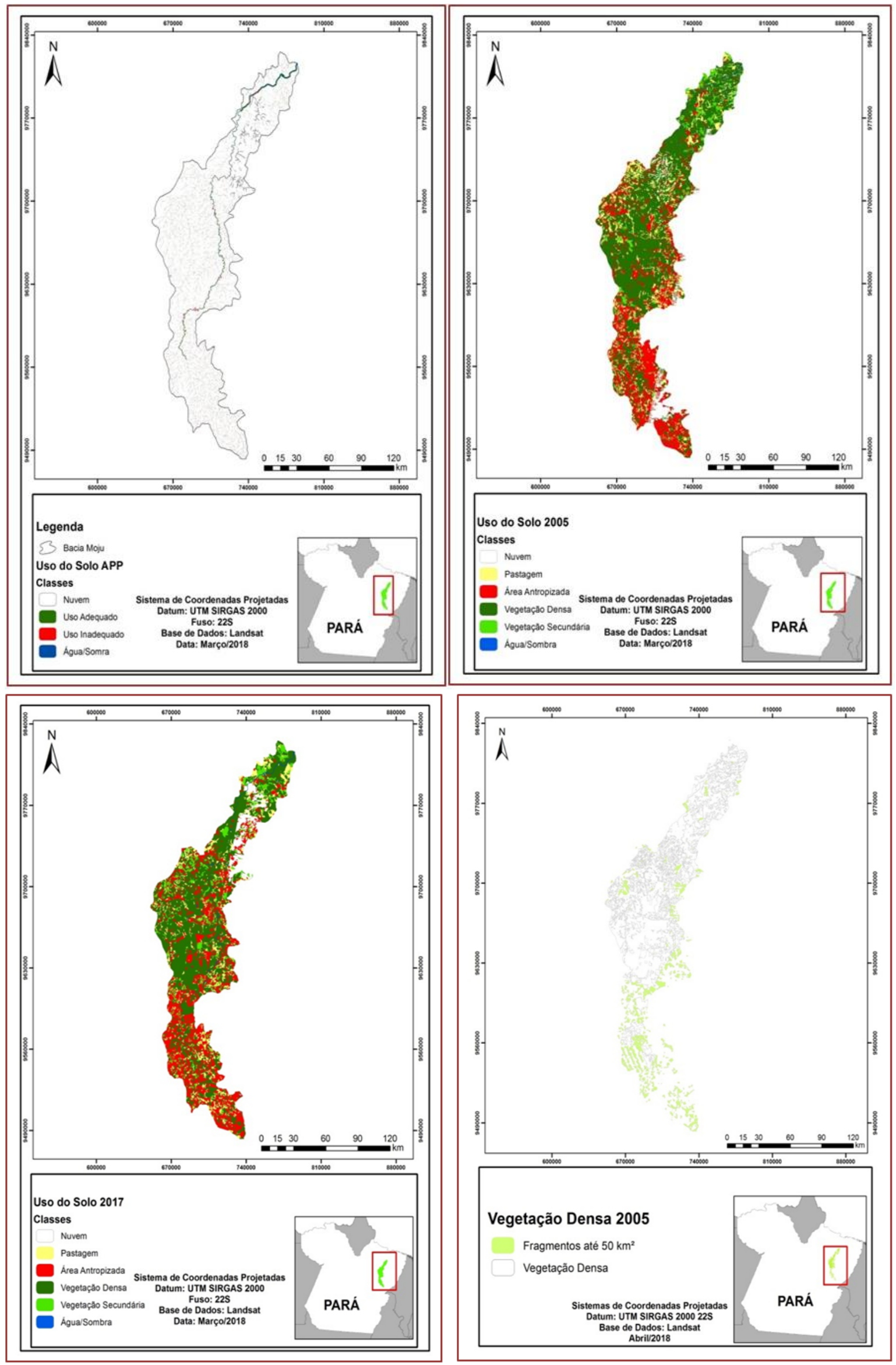

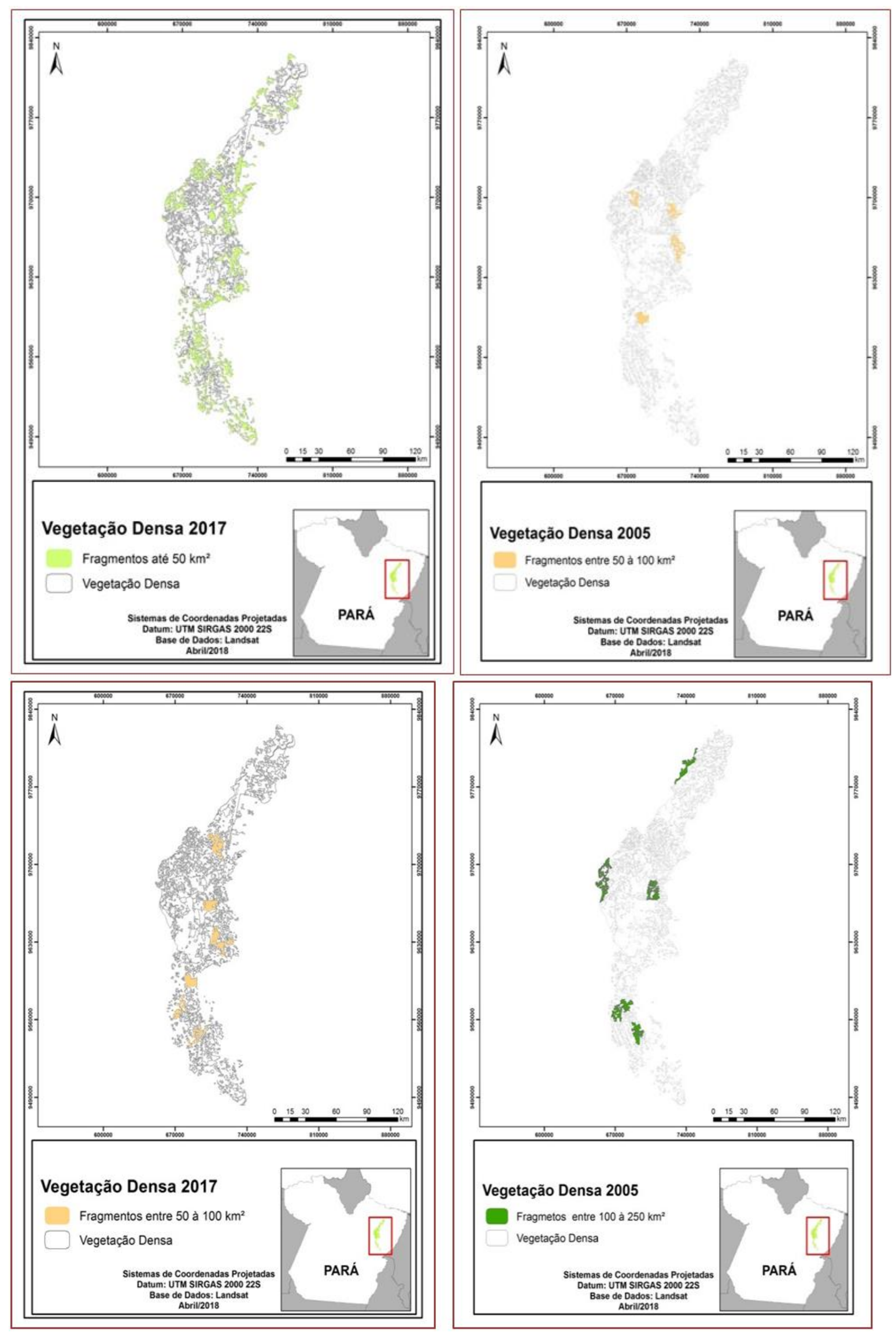

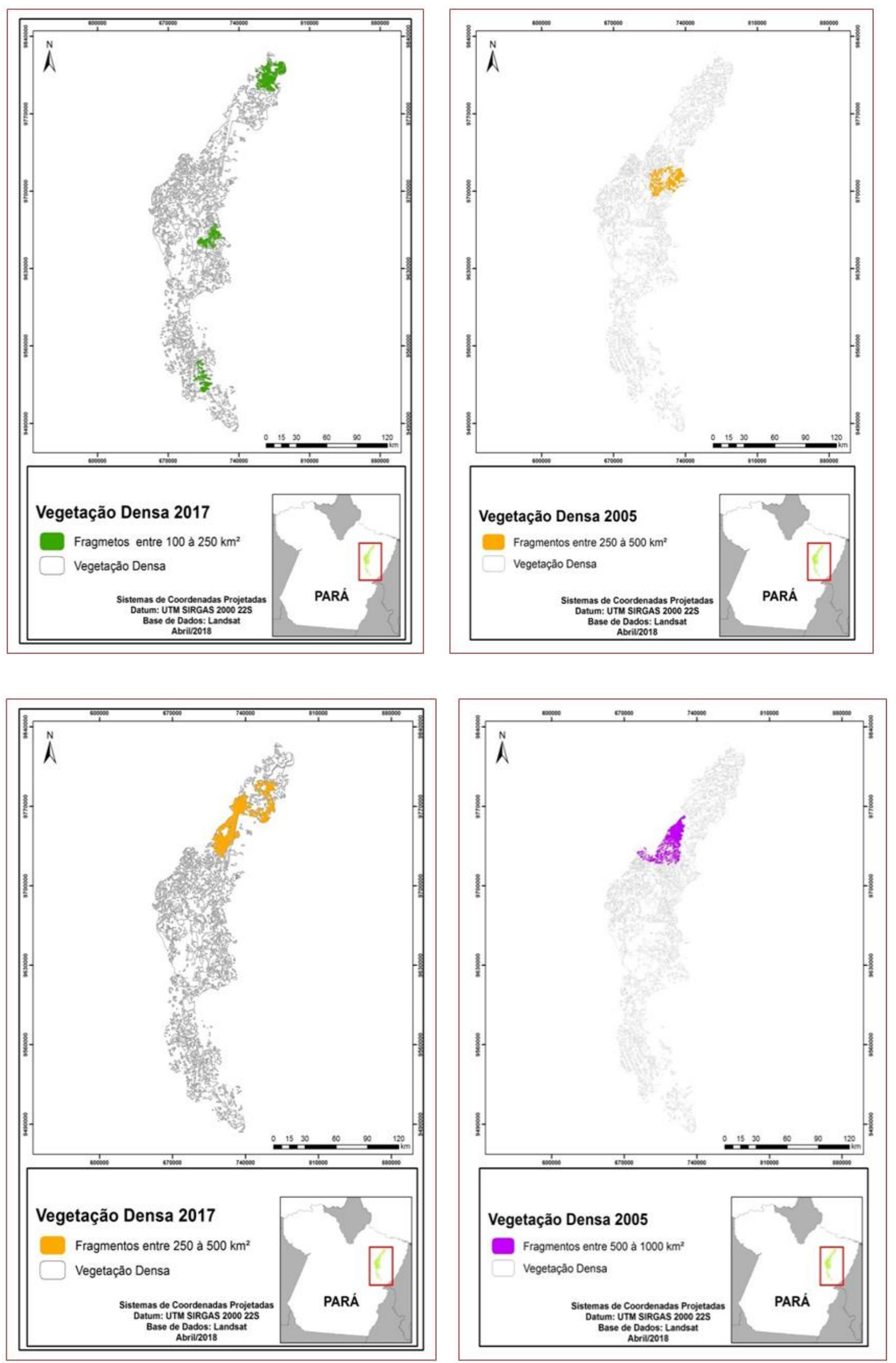

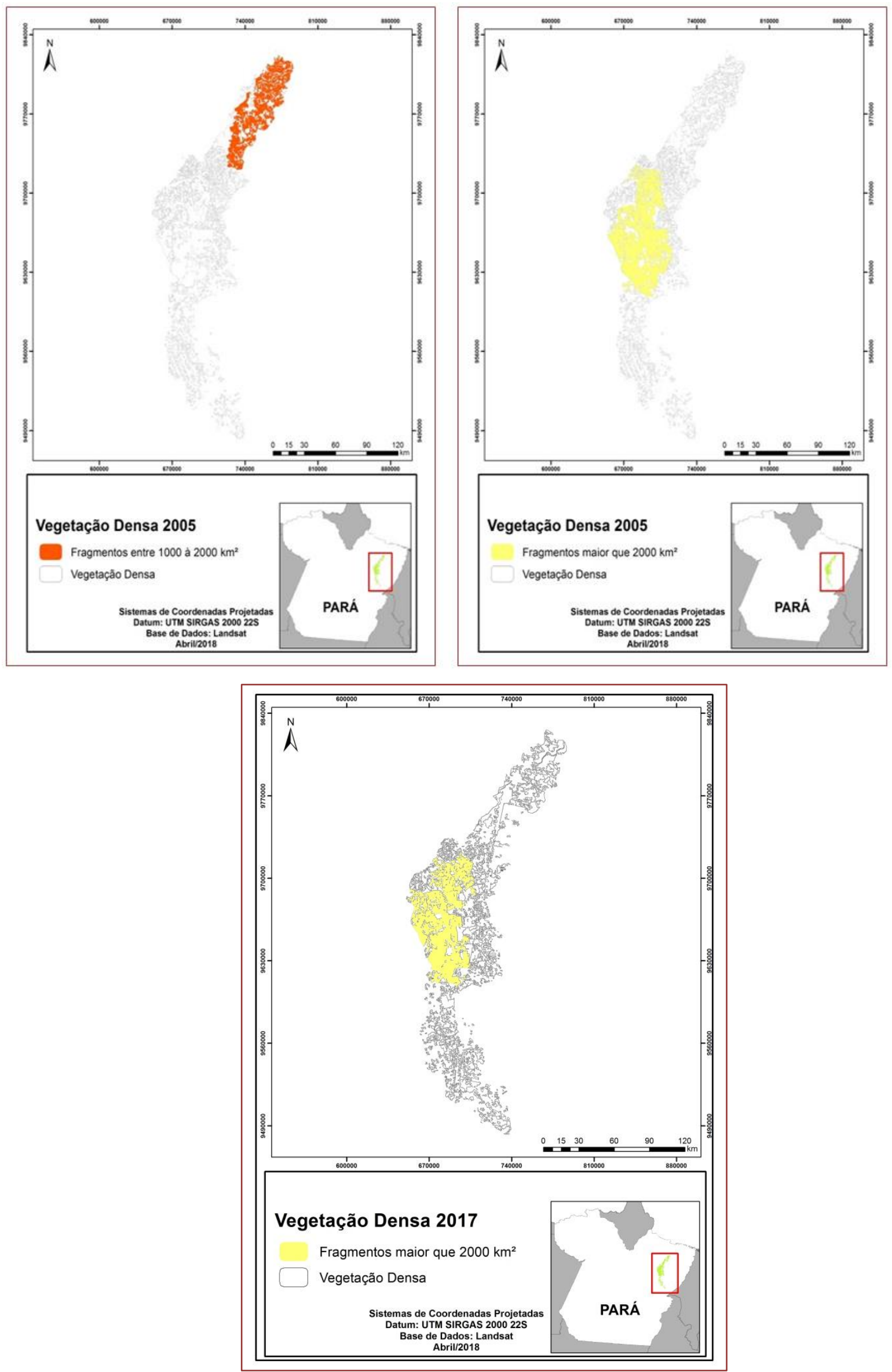


\section{CONCLUSÕES}

0 emprego de produtos e técnicas de sensoriamento remoto e de geoprocessamento permitiram realizar a caracterização e a análise dos elementos estruturais da paisagem da bacia hidrográfica do rio Moju, por meio da avaliação quantitativa e qualitativa dos fragmentos de vegetação densa encontrados na área do mesmo.

A paisagem analisada encontra-se bastante fragmentada, caracterizada pela presença de um número elevado de fragmentos pequenos, demonstrando o forte impacto da atividade humana na área. Verificouse uma elevada quantidade de fragmentos pequenos (com até 50 ha), o que indica que ocorreu um forte impacto da atividade humana na área da bacia hidrográfica do rio Moju, após a expansão da monocultura do dendê, conduzindo a um aumento do índice de dimensão fractal com o aumento da área no período de 2005 a 2017. Dessa forma, os fragmentos maiores tenderam a possuir formas mais complexas, ficando assim mais expostos aos efeitos de borda.

O comprometimento ambiental da paisagem da bacia hidrográfica do rio Moju no que tange à integridade ecológica tornou-se notório, uma vez que mais de $50 \%$ da sua área de vegetação densa com até 50 ha é constituída de ambiente de borda, fator que afeta significativamente a qualidade dos ecossistemas ali existentes.

A existência de alguns fragmentos mais conservados, com expressivas áreas centrais e bem conectados, são muito importantes para a conservação da biodiversidade na área de estudo, apesar de não serem em grande número, cumprindo um importante papel na manutenção da estabilidade da biodiversidade local.

Considerando o contexto em que se encontra a bacia hidrográfica do rio Moju, fazem-se necessárias medidas de planejamento estratégico vinculado à gestão e manejo deste, para contribuir no processo de recuperação e conservação dos fragmentos remanescentes e com isso viabilizar a manutenção dos ecossistemas e sua biodiversidade.

\section{REFERÊNCIAS}

[1] Almeida FS, Gomes DS, Queiroz JM. Estratégicas para a conservação da biodiversidade biológica em florestas fragmentadas. Ambiência 2011; 7(2): 367-382.

[2] Almeida, A. S. de. Mudanças de usos da terra em paisagens agrícolas com palma de óleo e implicações para a biodiversidade arbórea na Amazônia oriental. Tese(doutorado em ciências ambientais). Universidade federal do Pará/ Embrapa Amazônia Oriental/ Museu Paraense Emílio Goeldi, Belém, 2015.

[3] Alves, D. S. Pesquisa interdisciplinar em estudos ambientais. In: Vieira, I. C. G. et al.(Orgs.). Ambiente e sociedade na Amazônia: uma abordagem interdisciplinar. 1 ed. Rio de Janeiro. Ed. Garamond, 2014. p. 53-77.

[4] Brandão, F.; Schoneveld, G. The state of oil palm development in the Brazilian Amazon: trends, value chain dynamics, and business models. Working Paper 198. Bogor, Indonesia: CIFOR, 2015, 41p.

[5] Brondizio, E. S. Abordagens teóricas e metodológicas para o estudo de mudança de usos da terra. In: Vieira, I. C. G.; Toledo, P. M.; Santos JR. R. A. O. (org.)Ambiente e sociedade na Amazônia: uma abordagem interdisciplinar. 1 ed. Rio de janeiro: Garamond, 2014, p. 149-191.

[6] Brondizio, E. S.; Moran, E. F. Level-dependent deforestation trajectories in the Brazilian Amazon from 19702001. Population and Environment. Amsterdam, v. 104, 2012, p. 185-228.

[7] Daronco C, Melo ACG, Machado Jar. Consórcio de espécies nativas da floresta estacional semidecidual com mandioca (Manihot suculenta Crant) para restauração de mata ciliar. Revista Árvore 2012; 36(2): 291-299.

[8] Durães, F. O. M. Requerimentos de PD\&I na Agroindústria de Palma de Óleo no Brasil: O papel da Embrapa. Agroenergia em Revista. Edição 2. Maio 2011.

[9] Ewers, R. M.; Didham, R. K. Confounding factors in the detection of species responses to habitat fragmentation. Biological Reviews of the Cambridge Philosophical Society, v. 81, n. 1, p. 117-142, 2006. http://dx.doi.org/10.1017/S1464793105006949. PMid:16318651.

[10] Fitzherbert, Emily B.; Struebig, Matthew J.; Morel, Alexandra; Danielsen, Finn; Bruhl, Carsten A.; DONALD, PAUL F.; PHALAN, BEN. 2008 How will oil palm expansion affect biodiversity? Review in Trends in Ecology and Evolution Vol.23 No.10. 2008.

[11] Frank, S.; Fürst, C.; Koschke, L.; Makeschin, F. A contribuition towards a transfer of the ecosystem service concept to landscape planning using landscape metrics. Ecological Indicators, 21, 30-38, 2012. 
[12] Hanski I. Habitat LOSS, the dynamics of biodiversity, and a perspective on conservation. Ambio 2011; 40(3): 248-255.

[13] Holanda, A. C.; Feliciano, A. L. P.; Marangon, L. C.; Santos, M. S.; Melo, C. L. S. M. S.; Pessoa, M. M. L. Estrutura de espécies arbóreas sob efeito de borda em um fragmento de floresta estacional semidecidual em Pernambuco. Revista Árvore, v. 34, n. 1, p. 103-114, 2010. http://dx.doi.org/10.1590/S0100-67622010000100012.

[14] Homma, A. Agroenergia: a entrada de um novo ciclo na Amazônia? In: GOMES JÚNIOR, R. A. (Ed.). Bases técnicas para a cultura da palma de óleo integrado na unidade produtiva da agricultura familiar. Belém: Embrapa Amazônia Oriental, 2010, p. 3-5.

[15] Lees, A. C., Moura, N.G, Almeida, A. S. de., Vieira, I. C. G. Poor prospects for avian biodiversity in Amazonian oil palm. PLOS ONE, v. 10, n. 5. 2015.

[16] Muchailh, M.C.; Roderjan, C.V.; Campos, J.B.; Machado, A.L.T.;Curcio, G.R. (2010) Metodologia de planejamento de paisagens fragmentadas visando a formação de corredores ecológicos. Floresta, Curitiba, PR, v. 40, n.1, p. 147-162.

[17] Nahum, J. S.; Malcher, A. T. C. Dinâmicas territoriais do espaço agrário na Amazônia: a dendeicultura na microrregião de Tomé-Açu (PA). Revista Confins, Vol. 16, 2012, 15p.

[18] Nahum, J. S.; Santos, C. B dos. Uma interpretação geográfica da dendeicultura na Amazônia paraense. Revista da Associação Nacional de Pós-graduação e Pesquisa em Geografia (Anpege). v.11, n. 15, p.309-331, 2015.

[19] Rocha, G. de M. Ambientalização do território na Amazônia brasileira e a gestão ambiental. In: Vieira, I. C. G. et al., (Orgs.). Ambiente e sociedade na Amazônia: uma abordagem interdisciplinar. 1 ed. Rio de Janeiro: Garamond, 2014, p. 461-487.

[20] Silva, Maria do Socorro Ferreira da; Souza, Rosemeri Melo e. Padrões espaciais de fragmentação florestal na Flona do Ibura-Sergipe. Mercator-Revista de Geografia da UFC, v. 13, n. 3, 2014.

[21] Sousa, E. B.. M. L; Rocha, J. P. da. Climatologia, variabilidade e tendências do clima atual na Amazônia e em cenários futuros de mudanças climáticas. In: Vieira, I. C. G.; Toledo, P. M.; Santos JR. R. A. O. (org.) Ambiente e sociedade na Amazônia: uma abordagem interdisciplinar. 1 ed. Rio de Janeiro: Garamond, 2014, p. 295-312.

[22] Venturieri, A. Zondendê x Amarelecimento Fatal: Mapeamento de áreas com potencial de expansão e de ocorrência de amarelecimento fatal em palma de óleo (dendê) na Amazônia Legal, com ênfase no Estado do Pará. Agroenergia em Revista, (2). 2011.

[23] Zarin, D. J.; Davidson, E. A.; Brondizio, E. S.; Vieira, I. C. G.; Sá, T.; Feldpausch, T.; Schuur, E. A. G.; Mesquita, R.; Moran, E.; Delamonica, P.; Ducey, M. J.; Hurtt, G. C.; SALIMON, C.; Denich, M. Legacy of fire slows carbon accumulation in Amazonian forest regrowth. Frontiers in Ecology and Environment, v. 3. 2005, p. 365-369.

[24] Zhang, Q.; Seto, K. C. Mapping urbanization dynamics at regional and global scales using multi-temporal Dmsp/OLS nighttime light data. Remote Sensing of Environment, 2011.

[25] Ziller, S. R. A Estepe Gramíneo-Lenhosa no segundo planalto do Paraná: diagnóstico ambiental com enfoque à contaminação biológica. Tese (Doutorado em Engenharia Florestal) Universidade Federal do Paraná, Curitiba, 2005. 


\section{Capítulo 21}

Arborização do IFMT - Campus Cuiabá Bela Vista: Utilizando espécies nativas com potencial para sistemas agroflorestais

\section{Fabiana Farias de Araújo}

Gabriele Vitória Queiroz da Costa

Adaiane Catarina Marcondes Jacobina

Resumo: O IFMT - campus Cuiabá Bela Vista, passará por uma expansão da sua infraestrutura que intensificará os problemas já existentes no campus, sendo este a baixa cobertura vegetal do solo que acarreta processos de lixiviação, e acentuará ou criará ilhas de calor. Os sistemas agroflorestais (SAF's) surgem como forma alternativa de recuperação, uma vez que este propõe o consorcio de plantas nativas com culturas agrícolas para restabelecer a funções ecológicas. 0 objetivo desse trabalho será a arborização de 635,64 $\mathrm{m}^{2}$ de área verde do local, utilizando espécies nativas do cerrado sendo estas Cagaita- Eugenia dysenterica, Lobeira - Solanum lycocarpum, LixeiraCuratella americana, inibir ou amenizar o efeito das Ilhas de calor urbanas - ICU. O SAF é uma forma de integrar e utilizar as especificidades de cada espécie para restaurar áreas degradadas, paisagem rural e também a consorciação com lavouras visando assim pontos econômicos e ambientais interligados. Serão feitas covas de $40 \mathrm{~cm}$ nas 3 dimensões, e com espaçamento de $5 \times 5$ entre elas, cada cova receberá um substrato diferente. Espera-se que o percentual de crescimento da cagaita aumente devido a estar consorciada a lobeira, durante o período de germinação a lobeira exercerá um processo de inibição da lixeira e de favorecimento da Cagaita, mas que este processo desaparecerá durante o crescimento das plântulas. Aspira - se o cumprimento da lei municipal de número 5.144 de fevereiro de 2012, que estabelece a proporção de $80 \%$ das mudas a serem plantadas em área verde devem ser nativas da região. 


\section{INTRODUÇÃO}

As características locais precisam ser levadas em consideração quando falamos em infraestrutura, pois esta é imprescindível no controle do meio ambiente. À vista disso a percepção do meio natural deve ocorrer antes da urbanização. Em municípios de clima rigoroso, por ex emplo, não podemos mudar o clima regional, mas podemos utilizar dispositivos microclimáticos para criar espaços mais agradáveis (Duarte, 2000).

O desmatamento e o processo de lixiviação do solo fazem com que este perca a sua capacidade de produção e seus nutrientes. Os sistemas agroflorestais (SAF's) surgem como forma alternativa de recuperação, uma vez que este propõe o consorcio de plantas nativas com culturas agrícolas para restabelecer a funções (RIBASKI; MONTOYA; RODIGHERI, [20--]). O Instituto Federal de Mato Grosso, IFMT- campus Cuiabá Bela Vista, passará por uma expansão da sua infraestrutura e este crescimento intensificará os problemas já existentes no campus, sendo estes: a baixa cobertura vegetal que acarreta no processo de lixiviação do solo, e criará ilhas de calor.

Este trabalho tem como objetivo especifico arborizar $635,64 \mathrm{~m}^{2}$ do IFMT- campus Cuiabá Bela Vista, através da metodologia do SAF utilizando as plantas nativas do cerrado: Cagaita- Eugenia dysenterica, Lobeira -Solanum lycocarpum, Lixeira- Curatella americana, obedecendo a lei municipal de Cuiabá de número 5.144/ colocar o ano da lei.

\section{METODOLOGIA}

O plantio será realizado em uma área verde com extensão de 635,64 $\mathrm{m}^{2}$, do IFMT - Campus Cuiabá Bela Vista (-15.580593, -56.060696). 0 clima, segundo a classificação de Köppen-Geigerano, é do tipo Aw., tropical quente subúmido, de verão quente e chuvoso. 0 solo do campus é composto em sua maioria por areia, argila, slite e apresenta baixa disponibilidade de matéria orgânica (Pedralino, 2013).

A terra será gradeada, antes do plantio será utilizada a técnica da adubação verde, que Consiste em adicionar plantas leguminosas na superfície do solo com a finalidade de enriquecê-lo com nitrogênio e com o aumento deste melhorar a produção de biomassa vegetal. Em seguida será feita a retirada destas leguminosas, deixando o resto da cultura sob o solo formando uma cobertura para este, após isto serão feitas as covas medindo $40 \mathrm{~cm}$ nas 3 dimensões, cada cova terá o espaçamento de $5 \mathrm{x} 5 \mathrm{~m}$, as plantas serão intercaladas para dificultar a proliferação de pragas entre as culturas, os substratos serão diferentes para cada muda, as covas serão feitas seguindo o Instituto Brasileiro de Florestas - IBF (2012). As covas onde serão plantadas as lobeiras receberão os seguintes substratos: $30 \%$ de areia saibro (vermelha) e cerca de 5 a 6 pás de composto orgânico, isso 3 meses antes do plantio. Para Cagaita convém misturar $30 \%$ de areia $+30 \%$ de matéria orgânica e $500 \mathrm{~g}$ de cinzas de madeira aos $30 \mathrm{~cm}$ de terra da superfície da cova, não foi encontrado na literatura o substrato ideal para o plantio da Lixeira.

\section{RESULTADOS E DISCUSSÃO}

Almeja-se que o percentual de crescimento da cagaita aumente, devido a estar consorciada a lobeira, durante o período de germinação. A lobeira exercerá um processo de inibição da lixeira e de favorecimento da Cagaita, acredita-se que o crescimento e a taxa de germinação sejam maior que o do apresentado por Damasco (2011) uma vez que o experimento dele ocorreu em uma antiga área de mineração.

\section{CONCLUSÕES}

Espera-se que a Lobeira não afete de modo significativo o crescimento da cagaita e da lixeira e também que o percentual de crescimento da cagaita aumente devido está a estar consorciada a lobeira, durante o período de germinação a lobeira exercerá um processo de inibição da lixeira e de favorecimento da cagaita, mas que este processo desaparecerá durante o crescimento das plântulas. Aspira - se o cumprimento da lei municipal de número 5.144 de fevereiro de 2012, que estabelece a proporção de $80 \%$ das mudas a serem plantadas em área verde devem ser nativas da região. 


\section{REFERÊNCIAS}

[1] Damasco, Gabriel; Corrêa, Rodrigo Studart. Germinação e desenvolvimento de duas espécies de cerrado semeadas em consórcio com Solanum lycocarpum. St.-HIL. em uma cascalheira no Distrito Federal. Estudo Biologia, Brasília, v. 33, n. 32, p.76-81.2011. Disponível em: file://C:/Users/gabby/Desktop/Arborização do Campus/bs5943.pdf>. Acesso em: 01 jun. 2018.

[2] Duarte, Denise Helena Silva; Serra, Geraldo Gomes. Padrões de ocupação do solo e microclimas urbanos na região de clima tropical continental brasileira: Correlações e proposta de um indicador. Ambiente Construído, Porto Alegre, v. 3, n. 2, p.7-20, 2003. Trimestral. Disponível em: <file:///C:/Users/IFMTBLV374718/Downloads/344711839-1-PB.pdf>. Acesso em: 25 de maio 2018.

[3] Manual de Plantio IBF- Instituto Brasileiro de Florestas. Disponível em:<https://www.ibflorestas.org.br/news/manual.de.plantio.pdf> .Acesso em: 26 de junho de 2018.

[4] Martinotto, Fernando; Martinotto, Cristiano; Coelho(, Maria de Fatima Barbosa. Sobrevivência e crescimento inicial de espécies arbóreas nativas do Cerrado em consórcio com mandioca. Pesquisa Agropecuária Brasileira, Brasília, v. 47, n. 1, p.22-29.2012. Disponível em: \&lt;http://www.scielo.br/pdf/pab/v47n1/47n01a04.pdf\&gt;. Acesso em: 01 de junho

[5] Pedralino, Francielly de Oliveira; Barbosa, Bruno da Silva; CABRAL, Ian Felipe.Indicadores Ambientais de Solos do Instituto Federal de Mato Grosso, Campus Cuiabá-Bela Vista. In: Congresso Brasileiro de Gestão Ambiental, 4., 2013, Salvador. Anais...Salvador: Ibeas - Instituto Brasileiro de Estudos Ambientais, 2013. p. 1 - 5. Disponível em: \&lt;http://www.ibeas.org.br/congresso/Trabalhos2013/I-032.pdf\&gt;. Acesso em: 01 jun. 2018.

[6] Sais, A. C.; Oliveira, R. E. Distribuição de Sistemas Agroflorestais no Estado De São Paulo: apontamentos para restauração florestal e produção sustentável. 2018.132f. Dissertação (Mestrado em Desenvolvimento Regional). Universidade de Santa Cruz do Sul. Santa Cruz do Sul. 2018.

[7] Ribaski, Jorge; Montoya, Luciano Javier; Rodigheri, Honorino Roque. Sistemas Agroflorestais: aspectos ambientais e sócio-econômicos. Ambiente Brasil, [s.i.], v. 1, n. 1, p.2-6, jul. [20--]. Disponível em: \&lt;http://ambientes.ambientebrasil.com.br/agropecuario/artigo_agropecuario/sistemas_agroflor estais:_aspectos_ambientais_e_socio-economicos.html\&gt;. Acesso em: 01 jul. 2018.

<http://ambientes.ambientebrasil.com.br/agropecuario/artigo_agropecuario/sistemas_agroflor estais:_aspectos_ambientais_e_socio-economicos.html>. Acesso em: 01 jul. 2018. 


\section{Capítulo 22}

Estoque de c do solo sob cultivo do feijão-caupi em sistema de plantio direto no brejo paraibano

\section{Mary Anne Barbosa de Carvalho}

Ewerton da Silva Barbosa

Adailson Pereira de Souza

Helton de Souza Silva

Valeria Borges da Silva

Maria Idaline Pessoa Cavalcanti

Resumo: A passagem de ecossistemas naturais para uso com fins agrícolas pode exercer uma grande influência no destino do carbono (C) estocado nos solos. Este trabalho teve por objetivo, avaliar o potencial de preservação de C em um Latossolo Amarelo distrófico, nas profundidades de $0-10$ e $10-20 \mathrm{~cm}$, cultivado com feijão-caupi em sistema de plantio direto. 0 experimento foi conduzido na área experimental Chã-deJardim pertencente ao CCA da UFPB, no município de Areia, PB, seguindo um delineamento experimental em blocos casualizados, com 11 tratamentos (cinco doses de N, 2,5; 15; 25; 35 e 47,5 kg ha-1 e cinco doses de K, 3; 18; 30; 42 e $57 \mathrm{~kg}$ ha-1, acrescido de uma testemunha) e 4 repetições. 0 estoque de carbono foi determinado nas profundidades de 0 - 10 e $10-20 \mathrm{~cm}$ de cada parcela, o teor de carbono do solo foi determinado pelo método de oxidação da matéria orgânico com dicromato potássio, para realizar a conversão do teor de C do solo para Mg ha-1 determinou-se a densidade do solo nas duas profundidades pelo método do anel volumétrico. Os estoques de C orgânico nas camadas de 0 - 10 e 10 - 20 cm não foram influenciados significativamente pela adubação com diferentes doses de $\mathrm{N}$ e $\mathrm{K}$. $\mathrm{O}$ estoque de $\mathrm{C}$ orgânico do solo, em sistema de plantio direto, decresceu com a profundidade. Os maiores teores foram obtidos na camada superficial $(0-10 \mathrm{~cm})$ com 26,20 Mg ha-1. Este valor indica a elevada contribuição dos sistemas radiculares no aporte de $\mathrm{C}$ aos solos.

Palavras chave: Resíduos Vegetais; Nitrogênio; Potássio. 


\section{INTRODUÇÃO}

A remoção da cobertura vegetal natural do solo, altera o equilíbrio entre as entradas e saídas de resíduos na superfície causando, normalmente mais perdas do que ganho da matéria orgânica do solo (MOS), implicando na redução do $\mathrm{C}$ ao longo do tempo. 0 cultivo intensivo do solo para fins agrícolas, leva ao decréscimo da fertilidade e da capacidade produtiva. Acrescenta-se aos sistemas de cultivo convencional, além do revolvimento do solo a utilização de fertilizantes sintéticos, principalmente como fontes de $\mathrm{N}$, apontado como a grande responsável pela produção antrópica de $\mathrm{N}_{2} \mathrm{O}$, um dos principais gases do efeito estufa (GEE) (BERGSTROM et al., 2001).

Nesse sentido o conceito de agricultura sustentável tem se apresentado como uma solução para os problemas ambientais e econômicos decorrentes do mau uso do solo. Assim, tem aumentado a procura por alternativas para restabelecer as propriedades do solo dentro de níveis que permitam a sua restauração, sem afetar a produtividade e com o mínimo de danos ao meio ambiente, como a manutenção da matéria orgânica do solo (MOS) (ZOTARELLI, 2012).

A matéria MOS é um componente fundamental na qualidade dos sistemas agrícolas em razão do seu conteúdo e qualidade, compondo os fatores mais importantes que mantêm a fertilidade e a sustentabilidade agrícola (SANTOS et al., 2013). Ao ser decomposta, a matéria orgânica, libera nutrientes e forma os húmus, os quais em conjunto formam um fertilizante organomineral de alto valor agrícola (KIEHL, 1993) com capacidade de manter a produtividade dos solos em geral e o armazenamento de carbono no solo (ROMANO et al., 2013).

Além de trazer benefícios e atuar sobre alguns atributos, como o fornecimento de energia para o crescimento microbiano, aumentando a ciclagem de nutrientes (SILVA et al., 2011), o aumento da CTC e da fertilidade do solo (CAETANO et al., 2013), estruturação do solo (DAL FERRO et al., 2012) e complexação de elementos tóxicos (CAMPOS, 2010), a matéria orgânica do solo é de suma importância na avaliação da qualidade do mesmo (LOSS et al., 2010).

No Brasil, em especial as regiões nas regiões Norte e Nordeste, a produção de feijão se destaca pela sua grande importância socioeconômica e ambiental. Por serem capazes de fixar o nitrogênio atmosférico ajudam a reduzir o uso de fertilizantes sintéticos, diminuindo os custos de produção, além de reduzir a emissão de gases de efeito estufa na atmosfera (CONAB, 2017).

Para atender as necessidades de aumentar a produtividade, porém com atenção a sustentabilidade, práticas conservacionistas que visam manter ou reestabelecer a MOS, como adubação verde, rotação de culturas, plantio direto, consórcio de culturas, têm introduzido mudanças importantes na dinâmica do C no solo e favorecido seu sequestro. Sistemas que promovam a cobertura do solo, bem como o cultivo de as espécies que promovam a manutenção da matéria orgânica do solo, podem ser estratégias eficientes para utilização sustentável do uso dos solos.

\section{OBJETIVO}

Objetivou-se com este trabalho avaliar o potencial de preservação de $\mathrm{C}$ em um Latossolo Amarelo distrófico, nas profundidades de $0-10$ e $10-20 \mathrm{~cm}$, submetido a um sistema de plantio direto com a cultura do feijão-caupi.

\section{METODOLOGIA}

0 experimento foi conduzido na área experimental Chã-de-Jardim pertencente ao Centro de Ciências Agrárias da Universidade Federal da Paraíba (UFPB), no município de Areia, PB.

A área experimental apresenta relevo plano (<3\%), com Latossolo Amarelo distrófico, bem drenado, o qual foi caracterizado quimicamente (Tabela 1). 0 clima da região é definido como subtipo climático As' que corresponde ao clima tropical sub-úmido (quente úmido, com chuvas de outono-inverno) (Koppen e Geiger, 1936). 
Tabela 1. Características químicas do solo, na camada de $0-20 \mathrm{~cm}$ antes da instalação do experimento. (Ano 2016)

\begin{tabular}{|c|c|c|c|c|c|c|c|c|c|c|c|}
\hline $\mathrm{pH}$ & $\mathrm{P}$ & $\mathrm{S}-\mathrm{SO}_{4}^{-2}$ & $\mathrm{~K}^{+}$ & $\mathrm{Na}^{+}$ & $\mathrm{H}^{+}+\mathrm{Al}^{+3}$ & $\mathrm{Al}^{+3}$ & $\mathrm{Ca}^{+2}$ & $\mathrm{Mg}^{+2}$ & SB & CTC & M.O. \\
\hline Água(1:2,5) & ------- & $\mathrm{mg} / \mathrm{dm}^{3}$ & ------- & & - & $\mathrm{cmol}$ & $\mathrm{dm}^{3-}$ & 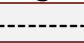 & --- & & -g/kg- \\
\hline 5,5 & 1,73 & - & 34,87 & 0,04 & 7,01 & 0,40 & 1,88 & 1,07 & 3,08 & 10,10 & 36,18 \\
\hline
\end{tabular}

P, K, Na: Extrator Mehlich 1

$\mathrm{H}+\mathrm{Al}$ : Extrator Acetato de Cálcio 0,5 M, pH 7,0

$\mathrm{Al}, \mathrm{Ca}, \mathrm{Mg}$ : Extrator $\mathrm{KCl} 1 \mathrm{M}$
SB: Soma de Bases Trocáveis.

CTC: Capacidade de Troca Catiônica

M.O.: Matéria Orgânica - Walkley-Black

O cultivo do feijão-caupi foi conduzido, seguindo um delineamento experimental em blocos casualizados, com 11 tratamentos e quatro repetições. Os tratamentos foram dispostos conforme a matriz Plan Puebla III (ALVAREZ, 1985), que consiste da combinação de cinco doses de $\mathrm{N}$, na forma de uréia $(2,5 ; 15 ; 25 ; 35$ e 47,5 $\mathrm{kg} \mathrm{ha}^{-1}$ ) e cinco doses de $\mathrm{K}$ na forma de cloreto de potássio (3; 18; 30; 42 e $57 \mathrm{~kg} \mathrm{ha}^{-1}$ ), acrescido de uma testemunha absoluta (não adubado) (Quadro 1).

Quadro 1. Combinação das doses de $\mathrm{N}$ e $\mathrm{K}\left(\mathrm{K}_{2} \mathrm{O}\right)$ segundo a matriz Plan Puebla III

\begin{tabular}{|c|c|c|}
\hline Tratamento & $\mathrm{N}$ & $\mathrm{K}$ \\
\hline 1 & 15 & 18 \\
\hline 2 & 15 & 42 \\
\hline 3 & 35 & 18 \\
\hline 4 & 35 & 42 \\
\hline 5 & 25 & 30 \\
\hline 6 & 2,5 & 18 \\
\hline 7 & 47,5 & 42 \\
\hline 8 & 15 & 3 \\
\hline 9 & 35 & 57 \\
\hline 10 & 2,5 & 3 \\
\hline 11 & 0,0 & 0,0 \\
\hline
\end{tabular}

Para realizar a amostragem do solo da área experimental utilizou-se trado holandês, sendo amostradas as camadas do solo de $0-10$ e $10-20 \mathrm{~cm}$ de cada parcela, em cada unidade experimental foi retirada três amostras simples de solo para formar uma composta. A coleta das amostras indeformadas, para determinação da densidade, foi realizada utilizando anel volumétrico acoplado ao trado de Uhland, considerando as mesmas profundidades.

As amostras deformadas foram secas ao ar, destorroadas e passadas em peneiras de malha 2,0 $\mathrm{mm}$ para obtenção da fração terra fina seca ao ar (TFSA) e, consequentemente, encaminhadas para fins de análises químicas do solo.

Foi determinado o teor de carbono orgânico (CO) do solo de cada amostra deformada e a densidade do solo (Ds) das amostras indeformadas, ambos, seguindo a metodologia sugerida em Embrapa (1997).

Parte das análises foram determinadas no Laboratório de Química e Fertilidade do Solo e as demais no Laboratório de Biotecnologia, ambos, do Departamento de Solos e Engenharia Rural do CCA, da Universidade Federal da Paraíba. 
O estoque de carbono (Est C) do solo, foi calculado em massa equivalente do solo. Com base no teor do carbono determinou-se o estoque de carbono na profundidade estudada, através da expressão (FERNANDES; FERNANDES 2008):

$$
\text { Est } \mathrm{C}=(\operatorname{COT} \times \text { Ds } \mathrm{x} \text { e) } / 10 \quad \text { equação } 1
$$

Onde:

Est $\mathrm{C}=$ estoque de $\mathrm{C}$ orgânico em determinada profundidade $\left(\mathrm{Mg} \mathrm{ha}^{-1}\right)$

COT = teor de C orgânico total na profundidade amostrada $\left(\mathrm{g} \mathrm{kg}^{-1}\right)$

Ds = densidade do solo $\left(\mathrm{kg} \mathrm{cm}^{-3}\right)$,

$\mathrm{e}=$ espessura da camada considerada $(\mathrm{cm})$.

Os dados foram submetidos a análise de variância e a diferença entre os tratamentos foram determinadas de acordo com a significância do teste de F a 5\% de probabilidade, utilizando o software SAEG versão 9.1 (Saeg, 2007).

\section{RESULTADOS E DISCUSSÃO}

Os estoques de C orgânico nas camadas de 0 - 10 e 10 - $20 \mathrm{~cm}$ não foram influenciados significativamente pela adubação com diferentes doses de N e K em relação a testemunha absoluta (N. adubado) (Figura 1).

Sistemas de cultivo com leguminosas como cultura principal, ou seu uso como cobertura do solo, pode aumentar os estoques de C, e a ciclagem de nutrientes no solo (XAVIER et al., 2013). A presença do sistema radicular ramificado e de raiz pivotante, confere às leguminosas a capacidade de reciclar, em maiores taxas os nutrientes das camadas mais profundas do solo, os quais retornam para o solo pelo aporte dos resíduos (SILVA, 2008).

Devido ao potencial de fixação de N, leguminosas podem reduzir a necessidade de adições de fertilizantes nitrogenados, diminuindo os impactos negativos nas emissões de gases de efeito estufa e mantendo a produtividade das culturas. Essa prática pode aumentar a eficiência do uso da terra e o rendimento total, garantindo a sustentabilidade das culturas (LUO et al., 2016).

Figura 1. Estoque de carbono (Est C) $\left(\mathrm{Mg} \mathrm{ha}^{-1}\right)$, nas camadas de 0 - 10 e $10-20 \mathrm{~cm}$, de um Latossolo Amarelo distrófico cultivado com feijão-caupi em sistema de plantio direto com diferentes doses de $\mathrm{N}$ e $\mathrm{K}$ (Adubado) e uma testemunha absoluta (N. Adubado), barras com as mesmas letras não diferem entre si pelo teste de $\mathrm{F}$ à $\% 5$ de probabilidade.

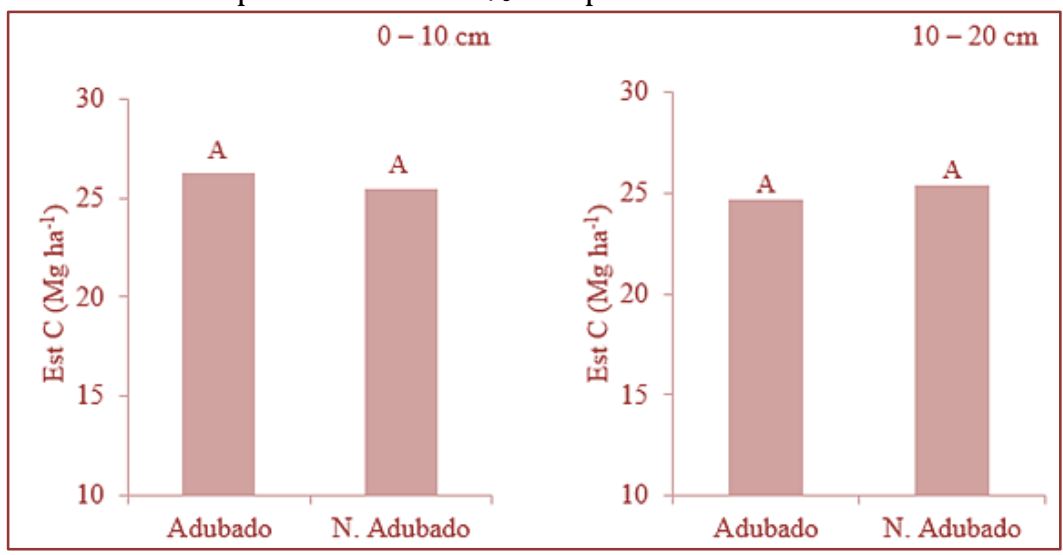

ElaboraçãoMary Anne B de Carvalho (2018) 
O estoque de $\mathrm{C}$ orgânico do solo, em sistema de plantio direto, decresceu com a profundidade. Os maiores

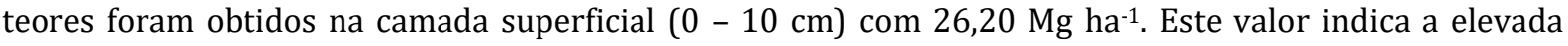
contribuição dos sistemas radiculares no aporte de $\mathrm{C}$ aos solos.

O maior armazenamento de matéria orgânica do solo, nas camadas superficiais, pelo aporte constante dos materiais na superfície também promove o aumento no teor de carbono orgânico do solo; e eleva a capacidade de fornecimento e retenção de nutrientes essenciais na rizosfera (SILVA, 2008).

A combinação entre cobertura de superfície do solo com resíduos de culturas e a diminuição da perturbação do solo contribui, diretamente, em redução da taxa de decomposição dos resíduos agrícolas pelo menor acesso pelos micro-organismos, resultando em diminuição da mineralização da MOS e, consequente, aumento do conteúdo de carbono do solo (CARBONELL-BOJOLLO et al., 2011; VIEIRA, 2007).

Figura 2. Estoque de carbono (Est C) $\left(\mathrm{Mg} \mathrm{ha}^{-1}\right)$, nas camadas de 0 - 10 e $10-20 \mathrm{~cm}$, de um Latossolo Amarelo distrófico cultivado com feijão-caupi em sistema de plantio direto, barras com as mesmas letras não diferem entre si pelo teste de $\mathrm{F}$ à $\% 5$ de probabilidade

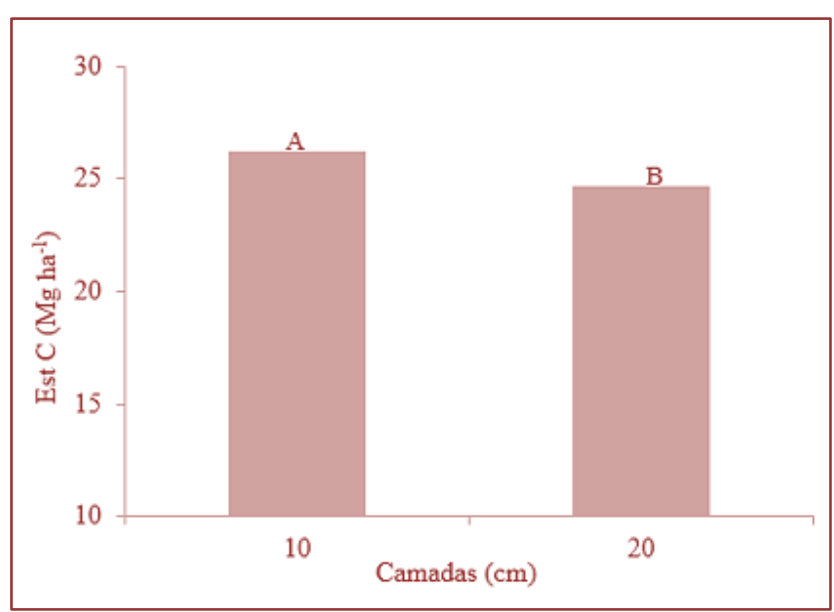

. Elaboração Mary Anne B. de Carvalho (2018).

O sistema de plantio direto (SPD) pode ser considerado uma atividade com potencial para sequestrar C no solo. Siqueira Neto et al. (2009) e Costa et al. (2008), avaliando o sequestro de C num Latossolo Vermelho distroférrico de textura argilosa e Argissolo Vermelho no sul do país, respectivamente, verificaram que o SPD associado à inclusão de culturas com alta adição de resíduos vegetais ricos em C e $\mathrm{N}$ e rotação com o uso de leguminosas reduziram a mineralização da matéria orgânica, o que favoreceu o acúmulo de C no solo.

\section{CONCLUSÃO}

$\mathrm{O}$ uso da adubação não representou ganhos no estoque de $\mathrm{C}$ do solo cultivado com feijão-caupi.

$\mathrm{O}$ acúmulo de $\mathrm{C}$ no solo com deposição de resíduos de feijão-caupi foi maior em superfície do que nas camadas mais profundas do solo. 


\section{REFERÊNCIAS}

[1] Alvarez Venegas, V.H. Avaliação da fertilidade do solo: superfície de resposta; modelos aproximativos para expressar a relação fator resposta. Viçosa: UFV, 1985. 75p.

[2] Bergstrom, D. W., Tenuta, M.; Beauch Amp, E. G. Nitrous oxide production and flux from soil under sod following application of different nitrogen fertilizers. Communications in Soil Science and Plant Analysis, Nova York, v. 32, p. 553-570, 2001.

[3] Caetano, J. O.; Benites, V. M.; Silva, G. P.; Silva, I. R.; Assis, R. L.; Filho, A. C. Dinâmica da matéria orgânica de um neossolo quartzarênico de cerrado convertido para cultivo em sucessão de soja e milheto. Revista Brasileira de Ciência do Solo, v.37 p.1245-1255, 2013.

[4] Campos, M. C. C. Atributos dos solos e riscos de lixiviação de metais pesados em solos tropicais. Ambiência Guarapuava, v.6 n.3, p. $547-565,2010$.

[5] Carbonell-Bojollo, R.; Gonzalezsanchez, E. J.; Veroz-Gonzalez, O.; Ordonez-FERNANDEZ, R. Soil management systems and short term $\mathrm{CO}_{2}$ emissions in a clayey soil in southern Spain. Science of the Total Environment, 2011.

[6] Companhia Nacional de Abastecimento. Acompanhamento da safra brasileira de grãos. v.1, n.1. 2017.

[7] Costa FS, Bayer C, Zanatta JA, Mielniczuk J. Estoque de carbono orgânico no solo e missões de dióxido de carbono influenciadas por sistemas de manejo no sul do Brasil. Revista Brasileira de Ciência do Solo, v.32, p. 323-32, 2008.

[8] Dal Ferro, N.; Berti, A.; Francioso, O.; Ferrari, e.; Matthews, G.P.; Morari, F. investigating the effects of wettability and pore size distribution on aggregate stability: the role of soil organic matter and the humic fraction. European Journal of Soil Science, v.63, p. 152-164, 2012.

[9] Embrapa. Centro Nacional de Pesquisa de Solos. Manual de métodos de análise de solo. 2. ed. rev. atual. Rio de Janeiro: EMBRAPA Solos, p. 212, 1997.

[10] Fernandes, F. A.; Fernandes, A. H. B. M. Cálculo dos estoques de carbono do solo sob diferentes condições de manejo. Corumbá: Embrapa Pantanal, 2009. 4 p. (Embrapa Pantanal. Comunicado Técnico, 69).

[11] Kiehl, Edmar José. Fertilizantes organominerais. Piracicaba: 0 autor, 1993. 189p.

[12] Köppen, W.; Geiger, R. Classificação climática de Köppen-Geiger. 1936.

[13] Loss, A.; Pereira, M. G.; Schultz, N. Quantificação do carbono das substâncias húmicas em diferentes sistemas de uso do solo e épocas de avaliação. Bragantia, v. 69, n. 4, p913-922, 2010.

[14] Luo, S.; YU, L.; Liu, Y.; Zhang, Y.; Yang, W.; LI, Z.; Wang, J. Effects of reduced nitrogen input on productivity and $\mathrm{N}_{2} \mathrm{O}$ emissionsin a sugarcane/soybean intercropping system. Europ. J. Agronomy, v.81, p.78-85, 2016.

[15] Santos, H. G.; Jacomine, P. K. T.; Anjos, L. H C.; Oliveira, V. A.; Lumbreras, J. F.; Coelho, M. R.; Almeida, J. A.; Cunha, T. J. F.; Oliveira, J. B. Sistema Brasileiro de Classificação dos Solos. 3. ed. Brasília: Embrapa, 2013, 353 p.

Silva, C. A. Uso de resíduos na agricultura. In: Fundamentos da matéria orgânica do solo: ecossistemas tropicais e subtropicais. 2. Ed. Porto Alegre: Metropole, 2008.

[16] Silva, T. R.; Menezes, J. F. S.; Simon, G. A.; Assis, R. L.; Santos, C. J. L.; Gomes, G. V. Cultivo do milho e disponibilidade de P sob adubação com cama-de-frango. Revista Brasileira Engenharia Agrícola e Ambiental, v.15, n.9, p.903-910, 2011.

[17] Siqueira Neto M, Venzke Filho SP, Piccolo MC, Cerri Cep, Cerri CC. Rotação de culturas no sistema plantio direto, em Tibagi (PR). I - Sequestro de carbono no solo. Revista Brasileira de Ciência do Solo, v.33, p.1013-22, 2009.

[18] Romano, R. A.; Milori, D. M. B. P.; Santos, C. H.; Nicolodelli, G.; Xavier, A. S. A. A. P.; Otaviani Junior, P. L.; VillasBoas, P. R. Avaliação do grau de humificação da matéria orgânica usando espectroscopia de plasma induzido por laser (libs). X Encontro Brasileiro de Substancias Húmicas. Embrapa, Brasília 2013.

[19] Vieira, F.C.B. Estoques e labilidade da matéria orgânica e acidificação de um argissolo sob plantio direto afetados por sistemas de cultura e adubação nitrogenada. 2007. 139 f. Tese (Doutorado) - Programa de Pós Graduação em Ciência do Solo, Faculdade de Agronomia, Universidade Federal do Rio Grande do Sul, Porto Alegre, 2007.

[20] Xavier, F. A. S.; Maia, S. M. F.; Ribeiro, K. A.; Mendonça, E. S.; Oliveira, T. S. Effect of cover plants on soil C and N dynamics in different soil management systems in dwarf cashew culture. Agriculture Ecosystems Environment, Amsterdan, v. 165, p. 173-183, 2013.

[21] Zotarelli, L. Influence of no-tillage and frequency of a green manure legume in crop rotations for balancing $\mathrm{N}$ outputs and preserving soil organic C stocks. Field Crops Research, v.132, p.185-195, 2012. 


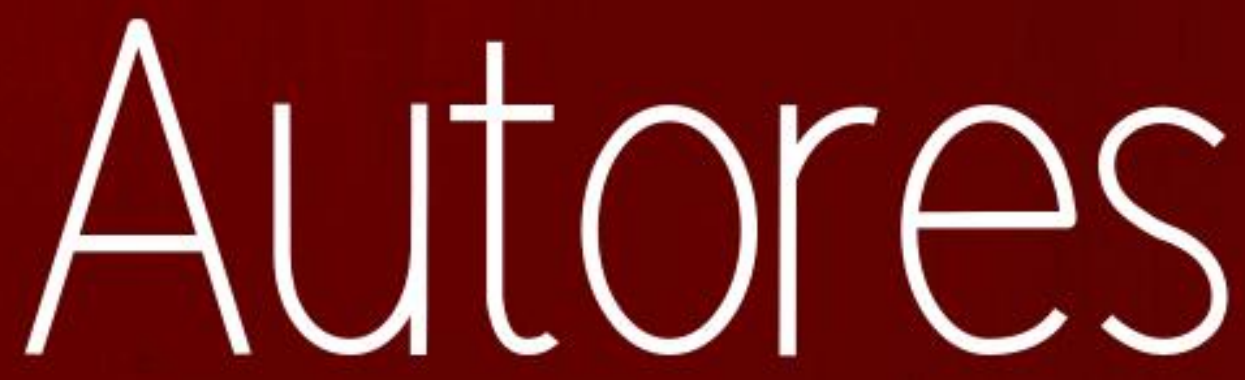




\section{FABIANE DOS SANTOS TOLEDO (Organizadora)}

Mestre em geografia pela Universidade Federal de Uberlândia, na área de planejamento ambiental, atuante em geociências, com ênfase em ambiental - áreas verdes, índice de áreas verdes, espaços públicos livres e parques urbanos. Possui graduação em Geografia (Licenciatura e Bacharelado) pela Universidade Federal de Uberlândia, mestrado em geografia pela Universidade Federal de Uberlândia. Tem experiência na área de Geociências, com ênfase em Geografia ambiental, atuando principalmente nos seguintes temas: áreas verdes, índice de áreas verdes, espaços públicos livres e parques urbanos.

\section{ADAIANE CATARINA MARCONDES JACOBINA}

Possui graduação em Ciências Biológicas pela Universidade Federal de Mato Grosso (UFMT), mestrado em Zoologia pelo Programa de Pós-Graduação em Zoologia da Universidade Federal de Mato Grosso, UFMT. Atualmente como Professora temporária do Instituto Federal de Mato GrossoCampus Bela Vista (IFMT-BLV) (2017/2-).

\section{ADAILSON PEREIRA DE SOUZA}

Possui graduação em Agronomia pela Universidade Federal da Paraíba (1990), mestrado em Solos e Nutrição de Plantas pela Universidade Federal de Viçosa (1993) e doutorado em Fitotecnia pela Universidade Federal de Viçosa (1998). Atualmente é professor associado do Departamento de Solos e Engenharia Rural da Universidade Federal da Paraíba. Tem experiência na área de Agronomia, com ênfase em Microbiologia e Bioquímica do Solo, atuando principalmente nos seguintes temas: nutrição mineral de plantas, fitorremediação, poluição e adubação mineral e orgânica.

\section{ADEID RODRIGUES SANTOS SILVA}

Graduada em Engenharia Ambiental pelo IFBA Campus Vitória da Conquista. Pós Graduada em Engenharia de Segurança do Trabalho pela UNIGRAD e Pós graduanda Docência em Biologia pela UNIVASF. Foi membro de grupo de pesquisa com ênfase em análise de água de corpos hídricos da bacia do Rio Verruga pela FAPESB. Foi membro da EAmbJr na área de licenciamento Ambiental. Atualmente é Engenheira Ambiental da Prefeitura Municipal de Jacaraci-BA, atuando nas áreas de Análise de Licenças Ambientais, Recuperação de Nascentes, Educação Ambiental e Plano de Gerenciamento de Resíduos Sólidos.

\section{ADERLANE LARANJEIRA}

Estudante do curso de licenciatura em Química e Biologia pela Universidade Federal do Amazonas

\section{ADRIELLI CRISTINA PERES DA SILVA}

Cursou Química pela Universidade Estadual Paulista “Júlio de Mesquita Filho" pela Faculdade de Ciências de Bauru Concluiu três projetos de Iniciação Científica na Área de Química Analítica, voltado para remediações de Áreas contaminadas por Metais Pesados; Mestrado em Biotecnologia pelo Programa de Pós Graduação oferecido pelo Instituto de Biociências de Botucatu, com enfoque em Ambiental; Atualmente Doutoranda também pelo referido Programa.

\section{ALEX BASSO}

Trabalhou com pesquisa na EMBRAPA e na Universidade Federal de Santa Catarina, onde já publicou 9 artigos em revistas internacionais e mais de 50 artigos em congressos nacionais e internacionais. Possui experiencia em Engenharia química, Agroecologia, processos químicos. É graduado em engenharia de Bioprocessos e Biotecnologia pela UERGS, Mestre em Agroecossistemas e esta concluindo o Doutorado em engenharia química pela UFSC. É revisor 
voluntário de diversos periódicos internacionais. É um profissional com conhecimento multidisciplinar.

\section{ALINE AGUIAR DOURADO}

Graduanda em Engenharia Ambiental pelo IFBA, campus Vitória da Conquista. Foi membro de grupo de pesquisa com ênfase em análise de água de corpos hídricos da bacia do Rio Verruga pela FAPESB. É membro-fundador da Empresa Júnior de Engenharia Ambiental - EAmbJr e membrofundador do Centro Acadêmico de Engenharia Ambiental - CAAMB. Atuou como assessora da área de Levantamento topográfico na EAmbJr e diretora da área de Gestão e Gerenciamento de Resíduos Sólidos e como Diretora de Pesquisa e Extensão do CAAMB.

\section{ÁLVARO MAGALHÃES LESSA}

Graduando em Arquitetura e Urbanismo pela Faculdades Santo Agostinho - FASAVIC

\section{ANDRÉ NIEDERSBERG DE ÁVILA}

Possui graduação em Artes Plásticas pela Universidade Federal da Bahia (2016) e Engenharia Agronômica pela Universidade Federal da Bahia(2000). Atualmente é professor de artes na galeria Marina Penalber no município de Itacoatiara ,na obra assistencial Chico Xavier e também ministra aulas de arteterapia no Caps de Itacoatiara além de prestar eventualmente serviços como responsável técnico na Empresa Alfama ,de fumigação em embarcações.Tem experiência na área de Artes, com ênfase em Artes Plásticas mas também atua como Engenheiro Agrônomo.

\section{ANDRÉIA GALVÃO SOARES}

Graduação em Gestão Ambiental. Instituto Federal de Educação Ciência e Tecnologia do Norte de Minas Gerais, IFNMG, Brasil.

\section{ANDRESA SAMPAIO SANTOS SOARES}

Graduada em Engenharia Ambiental pelo Instituto Federal da Bahia - IFBA, campus Vitória da Conquista. Foi membro de pesquisa com ênfase em Modelagem Matemática e computacional aplicado a sistemas ambientais durante três anos. É membro fundador do Centro Acadêmico de Engenharia Ambiental - CAAMB e da EAmbJr - Empresa Júnior de Engenharia Ambiental. Atualmente desenvolve pesquisa na área de poluição atmosférica, na qual foi contemplada com o $2^{2}$ lugar do Prêmio Arlindo Fragoso de Inovação e Tecnologia no ano de 2018.

\section{BRUNA MARIA DA HAMANO}

Graduada em Biomedicina pelo no Centro Universitário Sudoeste Paulista, UniFSP. Possui trabalhos e projetos acadêmicos nas áreas de Imunologia, Patologia e Microbiologia e Análises Ambientais.

\section{CAMILA FERREIRA BANNWART CASTRO}

É docente do Centro Universitário Sudoeste Paulista dos cursos de Biomedicina, Farmácia, Enfermagem, Fisioterapia, Odontologia e Medicina Veterinária. Atualmente é pós-doutoranda do Departamento de Patologia da Faculdade de Medicina de Botucatu, onde possui pós-doutorado pelo Departamento de Ginecologia e Obstetrícia. É doutora em Biologia Geral e Aplicada pelo Instituto de Biociências da Unesp- Botucatu- área de concentração: Biologia Celular, Estrutural e Funcional, com doutorado-sanduíche desenvolvido na Universidad de León, Espanha (2009). Mestre em Doenças Tropicais pela Universidade Estadual Paulista Júlio de Mesquita Filho (2006). Possui bacharelado em Ciência Biológicas com iniciação científica (2004) e treinamento técnico (2005) no Departamento de Microbiologia e Imunologia da Unesp, Botucatu. Possui experiência na área de Imunologia, especialmente em monócitos, vias de sinalização de células imunológicas como 
NF-kappa B, bem como, pré-eclâmpsia, doenças infecciosas e parasitárias, paracoccidiodomicose e silimarina.

\section{CATIA ROSANA LANGE DE AGUIAR}

Possui graduação em Engenharia Química pela Universidade Regional de Blumenau (1995), mestrado em Engenharia Química pela Universidade Federal de Santa Catarina (2004) e doutorado em Engenharia Química pela Universidade Federal de Santa Catarina (2014). É especialista em Processos Têxteis pela Universidade Federal de Santa catarina (2001) e especialista em Administração de Produção pelo Instituto Catarinense de Pós Graduação (2007). Já atuou em indústrias têxteis como supervisora, gerente e vendedora técnica durante 15 anos e meio. Professora Emérita do Centro Universitário Leonardo da Vinci - UNIASSELVI. Experiência de 5 anos em ensino fundamental e Professora de cursos de ensino superior desde 2003. Atualmente é professor adjunto da Universidade Federal de Santa Catarina. Tem experiência na área de Engenharia Química, com ênfase em Engenharia Têxtil, atuando principalmente nos seguintes temas: moda, desenvolvimento de produto, beneficiamento, cálculo e tratamento de efluentes.

\section{CINDY CAROLINA BENEDETTI FEDOCCI}

Bacharel em Serviço Social. Pontifícia Universidade Católica de Campinas - PUC-Campinas.

\section{CLAUDIO NAHUM ALVES}

Possui graduação em Licenciatura e Bacharelado em Química pela Universidade Federal do Pará (UFPA), especialização em Estatística pela UFPA-USP, mestrado em Química pela UFPA em 1998. Doutor em Ciências (Química) pela Universidade de São Paulo-IQSCar em 2001. Realizou estágio pós-doutoral nas Universidades de Valencia e Jaume I na Espanha (2005-2007) e Universidade da Florida nos Estados Unidos (2013-2014). Atualmente é Professor Associado IV da UFPA e coordenador do programa de Pos-Graduação em Ciências e Meio Ambiente do Instituto de Ciências Exatas e Naturais da UFPA.

\section{DÉBORA ROSA MIRANDA}

Ensino Médio completo - Colégio Estadual Nossa Senhora da Conceição - Miguel Calmon - BA ( Conclusão em 2011). 2011 - Curso de Informática Básica, Linux Metasys, Editor de Texto Openoffice. Org Writer, Planilha Eletrônica Openoffice. Org Cal e Internet. Carga horária de 48h. Programa de Inclusão Digital Telecentro Comunitário. 2011 - Curso "Como conseguir e Manter um Bom Emprego", carga horária de 240 minutos. Imega Cursos e Entretenimentos.

\section{RICARDO JORGE AMORIM DE DEUS}

Professor Adjunto no Instituto de Ciências Biológicas/ICB e no Instituto de Tecnologia/ITEC da Universidade Federal do Pará/UFPA, Professor Permanente no Programa de Pós-Graduação em Ciências e Meio Ambiente/PPGCMA da UFPA. Doutorado em Química com ênfase em Modelagem Ambiental Integrada pela Universidade Federal do Pará/UFPA (2012) e Doutorado Complementar no Departamento de Engenharia do Ambiente da Universidade Técnica de Lisboa/UTL-Portugal (2010-2012). Atualmente, Coordenador do Laboratório de Pesquisa em Meio Ambiente e Conservação/LaPMAC/CNPQ da UFPA e Pesquisador Associado do Marine Environment Technology Center/MARETEC da Universidade Técnica de Lisboa/UTL-Portugal.

\section{DIONE VITOR DOS SANTOS}

Curso de mestrado em Planejamento, Gestão Ambiental, Universidade Católica de Brasília, (UCBDF,2012), ênfase em política ambiental, educação ambiental, recursos hídricos e desenvolvimento sustentável. Especialização Política de Gestão de Ciência, Tecnologia, InovaçãoCentro de Desenvolvimento Sustentável (CDS), Universidade de Brasília (UNB-DF,2007). 
Graduação, Curso de Licenciatura Plena em História, Centro Universitário de Brasília (UNICEUB,1989). Analista em Ciência e Tecnologia, Ministério da Ciência, Tecnologia, (MCTIC).

\section{KÁTIA VIANA CAVALCANTE}

Doutorado em Desenvolvimento Sustentável pela Universidade de Brasília, Brasil(2013). Professora da Universidade Federal do Amazonas. Área de interesse: Gestão Ambiental; Indicadores de Desenvolvimento Sustentável

\section{DUARCIDES FERREIRA MARIOSA}

Sociólogo. Doutor em Sociologia, Investigador Integrado ao Centro de Investigações OBSERVARE da Universidade Autônoma de Lisboa - UAL - Portugal. Integrante do Grupo de Pesquisa Biotupé, Instituto Nacional de Pesquisas da Amazonia.

\section{EDILSON LUIZ CÂNDIDO}

Atualmente é docente no Instituto Federal de Educação, Ciência e Tecnologia do Sul de Minas, Campus Avançado Três Corações- IFSULDEMINAS. Graduado em Ciências Biológicas pelo Centro Universitário de Lavras - UNILAVRAS, Especialista em Gestão Ambiental de Sistemas Florestais pela Universidade Federal de Lavras - UFLA e Mestre em Educação Agrícola pela Universidade Federal Rural do Rio de Janeiro. Leciona disciplinas relacionadas com as Biológicas e Temas Ambientais no Ensino Profissional Integrado ao Ensino Médio, na Pós Graduação em Ensino em Ciências Naturais e Matemática e também na Pós em Gestão Estratégica em Negócios. Interesse em extensão e pesquisa na Grande área da Educação e Educação em Biologia.

\section{ELTON ALVES DE SOUZA FILHO}

Mestre em Gestão e Regulação de Recursos Hídricos da UEA/PROFÁGUA. Graduado em Tecnologia em Processos Químicos no Instituto Federal de Educação, Ciência e Tecnologia do Amazonas (IFAM). Formação de Nível Técnico Profissionalizante em Química formado pelo IFAM. Empregado da Petróleo Brasileiro S. A, lotado na Refinaria de Manaus (REMAN) no Laboratório de Qualidade de Produtos e Departamento de Águas Industriais e Efluentes.

\section{EMANUELLE DOS SANTOS LEMOS}

Graduanda em Arquitetura e Urbanismo pela Faculdades Santo Agostinho - FASAVIC

\section{VALDINEY FERREIRA DE ALMEIDA}

Mestrando em Ciências do Ambiente e Sustentabilidade na Amazônia do PPGCASA 2018 na Universidade Federal do Amazonas - UFAM; Especialista em Metodologia do Ensino Superior pela Faculdade Católica de Rondônia - FCR (2012); Graduação em Administração Geral pela Faculdade de Ciências Humanas Exatas e Letras de Rondônia (2006) e graduação em Matemática pelo Centro Universitário Claretiano de Batatais (2009); Docente de Administração do Instituto Federal de Educação, Ciência e Tecnologia do Amazonas - IFAM/Campus Eirunepé.

\section{EVELYN LAURIA NORONHA}

Doutora em Educação na Área de Ciências Sociais na Educação da FE/UNICAMP. Mestre em Educação e Especialista em Psicopedagogia ambos pela Universidade Federal do Amazonas. Bacharel em Filosofia pela Universidade Federal do Rio de Janeiro, em Teologia pelo Instituto de Teologia - São Paulo, e, em Direito pela Universidade do Estado do Amazonas (UEA/AM). Docente do Programa de Pós-Graduação em Educação e Ensino de Ciências na Amazônia na Universidade do Estado do Amazonas, desempenhando atividades de orientação junto ao Programa. Professora da graduação na Universidade do Estado do Amazonas. 


\section{EWERTON DA SILVA BARBOSA}

Técnico em Agropecuária pela Universidade Estadual da Paraíba. Graduando em Agronomia na Universidade Federal da Paraíba, com previsão de término para 2019. Tem experiencia com temas transversais em Agronomia e Agroecologia. Atualmente é bolsista de Iniciação Científica.

\section{FABIANA FARIAS DE ARAÚJO}

Aluna egressa do curso técnico de meio ambiente integrado ao ensino médio do Ifmt.Ingressante na Universidade Federal de Mato Grosso no ano de 2019.

\section{GRACIETE DA SILVA FIGUEIREDO}

Mestra em Ciências e Meio Ambiente pelo Programa de Pós Graduação pelo Instituto de Ciências Exatas e Naturais - ICEN da Universidade Federal do Pará- UFPA. Especialista em Psicopedagogia pela Universidade Vale do Acaraú (UVA); Educação Especial e Inclusiva, Docência do Ensino Básico e Superior (Instituto Carreira); Gestão Pública com ênfase em Gestão por Competência (UFPA/Universidade Federal Rural da Amazônia- UFRA); Gestão em Saúde (UFPA). Graduação em Pedagogia pela UFPA. Técnica Administrativa da Universidade Federal do Pará, lotada no Hospital Universitário João de Barros Barretos. Professora Participante do Programa de Extensão da UFPA em Educação Ambiental. Professora da Educação Básica do município de Ananindeua/Pará; foi professora de Educação Básica no município de Acará/Pará.

\section{GABRIELE VITÓRIA QUEIROZ DA COSTA}

Aluna egressa do curso técnico de meio ambiente integrado ao ensino médio do IFMT. Ingressante na Universidade Federal de Mato Grosso no ano de 2019.

\section{GABRIELI COELHO DE SOUZA HEIMOSKI RIBEIRO}

Aluna do curso de Engenharia Têxtil da Universidade Federal de Santa Catarina. Bolsista de Iniciação Científica, com bolsa Pibiq do CNPq.

\section{GEOVANNA CARVALHO CARDOSO LIMA}

Discente na Universidade Estadual de Santa Cruz, no curso de Enfermagem Bacharelado. Apresenta experiência em métodos laboratoriais para especiação de larvas de geohelmintos e outros parasitas encontrados em sedimentos de solos.

\section{HELTON DE SOUZA SILVA}

É bacharel em agronomia pela Universidade Federal de Campina Grande. Atualmente é acadêmico do Programa de Pós-Graduação em Ciência do Solo da Universidade Federal da Paraíba.

\section{HUMBERTO JORGE JOSÉ}

Possui graduação em Química pela Universidade Federal de Santa Catarina (1977), mestrado em Físico-Química pela Universidade Federal de Santa Catarina (1984) e doutorado em Química pela Universidade de Aachen-RWTH Aachen, Alemanha(1989), com ênfase na área de Engenharia Química. É Professor Titular da Universidade Federal de Santa Catarina, atuando no Programa de Pós-Graduação em Engenharia Química.

\section{IGOR OTÁVIO MINATEL}

Possui Graduação em Biomedicina (2006), Especialização em Imunopatologia (2009), Mestrado (2011) e Doutorado (2015) em Patologia pela Faculdade de Medicina de Botucatu - UNESP. Realizou doutorado sanduíche no Jean Mayer USDA - Human Nutrition Research Center on Aging, 
USA. Atualmente é pós-doutorando na área de Química e Bioquímica. Tem experiência na área de Compostos bioativos, Estresse oxidativo, Inflamação, Bioquímica, Imunologia e Microbiologia, atuando principalmente nos seguintes temas: Identificação de compostos bioativos, Bioquimica aplicada, Bioacessibilidade, Biodisponibilidade, Fitonutrientes, Cultura celular e Células tronco mesenquimais

\section{ITANI SAMPAIO DE OLIVEIRA}

Possui graduação em Geologia pela Universidade Federal do Amazonas - UFAM, pós-graduação em Perícia, Auditoria e Gestão Ambiental pela Faculdade Metropolitana de Manaus - FAMETRO, especialização em Didática do Ensino Superior pela Universidade Nilton Lins e mestrado em Ciências e Meio Ambiente pela Universidade Federal do Pará - UFPA. Técnica em Geociências no Serviço Geológico do Brasil (Companhia de Pesquisa de Recursos Minerais - CPRM), tem experiência na área de Recursos Hídricos, Resíduos Sólidos, Educação e Meio Ambiente, Mineração.

\section{JOÃO UBIRATAN MOREIRA DOS SANTOS}

Possui graduação em Licenciatura em Ciências Biológicas pela Universidade Federal do Pará (1975), graduação em Ciências Biológicas - Modalidades Médicas pela Universidade Federal do Pará (1974), mestrado em Biologia Vegetal pela Universidade Estadual de Campinas (1984) e doutorado em Biologia Vegetal pela Universidade Estadual de Campinas (1992). Atualmente é Professor Associado da Universidade Federal Rural da Amazônia. Tem experiência na área de Botânica, com ênfase em Taxonomia de Fanerógamos, atuando principalmente nos seguintes temas: restinga, amazônia, taxonomia, heliantheae e compositae

\section{JORNEY MOREIRA BARBOSA}

Atualmente graduando do Curso de Agronomia no Instituto de Ciências Exatas e Tecnologia (ICETUFAM)

\section{JOSÉ CARLOS MIERZWA}

Pós-doutorado na Escola de Engenharia e Ciências Aplicadas de Harvard (2011), livre docência na Escola Politécnica da USP (2009), doutorado em Engenharia Civil [Sp-Capital] pela Universidade de São Paulo (2002), mestrado em Tecnologia Nuclear pela Universidade de São Paulo (1996). Professor pesquisador da Universidade de São Paulo, desde maio de 2013, Vice chefe do Departamento de Engenharia Hidráulica e Ambiental, Coordenador do Curso de Engenharia Ambiental da Escola Politécnica e Coordenador do Programa Poli-USP Recicla.

\section{JOSÉ CAVALCANTE LACERDA JUNIOR}

Graduado em Filosofia, Teologia e Psicologia. Mestre em Educação em Ciências na Amazônia pelo Programa de Pós-Graduação em Educação e Ensino de Ciências na Amazônia - PPGEECA da Universidade do Estado do Amazonas - UEA. Doutor em Ciências do Ambiente e Sustentabilidade na Amazônia pelo Programa de Pós-Graduação em Ciências do Ambiente e Sustentabilidade na Amazônia - PPGCASA da Universidade Federal do Amazonas - UFAM. Pesquisa atualmente temas relacionados a infância, crianças, Amazônia, culturas e ciências. Atua como psicólogo na Secretaria de Estado de Saúde do Amazonas e como professor de Filosofia e Psicologia na rede pública e particular de ensino.

\section{JOSÉ DA SILVA JUNIOR}

Aluno do curso de Fisioterapia em uma faculdade particular como bolsista. 
Licenciando e Bacharelando em Ciências Sociais. Pontifícia Universidade Católica de Campinas PUC-Campinas.

\section{MAIARA DE SOUZA NUNES ÁVILA}

Professora Adjunta do Instituto de Ciências Exatas e Tecnologia, da Universidade Federal do Amazonas, Engenheira Agronôma, Mestre em Ciências Agrárias pela Universidade Federal da Bahia e Doutora em Biotecnologia pela Universidade Estadual de Feira de Santana. Lecionou nos cursos de Engenharia Agronômica e Engenharia de Pesca na Universidade Federal da Bahia (2005 - 2006) e no curso de Bacharel em Farmácia na Faculdade Maria Milza, em Cruz das Almas, Bahia (20072008). Atua nos cursos de graduação em Licenciatura em Ciências: química e biologia, Engenharia Sanitária e Agronomia. É responsável pelas disciplinas: Anatomia e Morfologia vegetal, Biologia Celular, Sistemática vegetal e Fisiologia Vegetal, do eixo básico do curso de agronomia e leciona disciplinas afins em outros cursos de graduação. Na área administrativa, atuou como membro do colegiado (2014 a 2018), do núcleo docente estruturante do curso de agronomia (2014 a 2019) e Coordenadora do Curso de Agronomia (2016 -2018). Desde 2014, coordena projetos de extensão universitária nas áreas de educação, meio-ambiente e ciências agrárias e projetos de iniciação científica nas áreas cultivo orgânico e bioprodutos de plantas medicinais. Têm experiência nas áreas de biotecnologia, cultivo orgânico, sementes oleaginosas para produção de biocombustíveis, produção vegetal, produção de mudas, fisiologia vegetal e microbiologia.

\section{MAÍRA ANUNCIAÇÃO BRITO DE OLIVEIRA}

Acadêmica do curso de Ciências Contábeis da Universidade Federal do Amazonas. Pesquisadora na área de Ciências Contábeis.

\section{MARCELO FERNANDES DA SILVA}

Bacharel em Ciências Biológicas pela Universidade Estadual Paulista Júlio de Mesquita Filho (1990), mestre em Imunologia Básica e Aplicada (1993) e doutor em Imunologia Básica e Aplicada pela Faculdade de Medicina de Ribeirão Preto, Universidade de São Paulo (1998). Exerceu a gestão acadêmica dos cursos de Biomedicina e do Curso Tecnológico de Gestão em Biotecnologia e foi docente permanente do Programa de Mestrado em Odontologia da Universidade de Uberaba. Foi professor substituto do Centro de Formação Especial em Saúde - CEFORES da Universidade Federal do Triângulo Mineiro e docente dos cursos de graduação em Medicina, Enfermagem. Fisioterapia, Educação Física, Fonoaudiologia, Odontologia e Psicologia além de ex-coordenador da Pós-graduação e da Comissão Própria de Avaliação da Universidade de Uberaba/MG (1997-2011). Atualmente é professor titular da Universidade Estadual de Santa Cruz/BA, docente permanente do Programa de Mestrado em Ciências da Saúde, com experiência em projetos interdisciplinares em biologia e saúde com ênfase em imunologia e parasitologia básica e clínica, biotecnologia, saúde pública, modelos de atenção à saúde.

\section{MARCOS DE LARA MAIA}

Possui graduação em Engenharia Agronômica pela Universidade Federal de Viçosa (1984), graduação em Direito pelo Instituto de Educação Superior de Brasília-IESB (2013), mestrado em Planejamento e Gestão Ambiental pela Universidade Católica de Brasília (2006) e Pós-Graduação em Geoprocessamento pela Universidade de Brasília-UnB (2007). Foi professor na Secretaria de Educação do DF (1992 a 2014) e atualmente é extensionista rural pela Empresa de Assistência Técnica e Extensão Rural - EMATER-DF (1995 até os dias de hoje). Tem experiência na área de Agronomia, com ênfase em Agronomia, atuando principalmente nos seguintes temas: licenciamento ambiental, adequação da propriedade rural conforme exigência da legislação ambiental. Os trabalhos na EMATER-DF tem ênfase na Agricultura Familiar. Na área do Direito tem ênfase no Direito Ambiental com experiência na defesa administrativa de propriedades autuadas por órgãos ambientais, participação de grupos de trabalhos para elaboração de Leis ambientais no DF e no Direito Agrário 


\section{MARCUS VINICIUS SILVA SANTOS}

Professor do Instituto Federal de Educação, Ciência e Tecnologia da Bahia (2012-presente) Licenciado em Ciências Biológicas (UEFS 2003-2008). Especialista em Biologia Celular ((UEFS 2010-2011). Mestre em Ciências Ambientais (UEFS 2013-2015). Doutorando em Geoquímica: Petróleo e Meio Ambiente (UFBA 2016-presente

\section{MARIA DE NAZARÉ MARTINS MACIEL}

Graduada em Agronomia e Engenharia Florestal pela Universidade Federal Rural da Amazônia, mestrado em Ciências Florestais pela Universidade Federal Rural da Amazônia (1989) e Doutorado em Engenharia Florestal pela Universidade Federal do Paraná (2002). Atualmente é professora associada IV da Universidade Federal Rural da Amazônia. Tem experiência na área de Recursos Florestais e Engenharia Florestal, com ênfase em Inventário e Manejo Florestal, com os ferramentais de sensoriamento remoto e sistemas de informações geográficas. A linha investigativa de pesquisa e aplicações envolve o tratamento de dados espaciais no levantamento e monitoramento da cobertura vegetal, modelagem e análise espacial do meio ambiente.

\section{MARIA IDALINE PESSOA CAVALCANTI}

Possui graduação em Agronomia pela Universidade Federal da Paraíba (2013) e mestrado em Ciências Agrárias pela Universidade Estadual da Paraíba (2016), onde desenvolveu pesquisas no Laboratório de Microbiologia do Solo da Embrapa Semiárido com ênfase em microbiologia do solo , trabalhando na seleção de bactérias promotoras de crescimento e na Fixação Biológica do Nitrogênio. Atualmente cursando Doutorado em Ciência do Solo-UFPB

\section{MARIA INÊS GASPARETTO HIGUCHI}

Possui graduação em Psicologia pela Pontifícia Universidade Católica do Paraná (1979), mestrado em Ecologia Humana - Michigan State University (1986) e doutorado em Antropologia Social Brunel University of London (1999). Atualmente é pesquisadora titular do Instituto Nacional de Pesquisas da Amazônia, coordenando o Laboratório de Psicologia e Educação Ambiental. Também atua como professora membro permanente dos cursos de Mestrado em Psicologia e do Programa de Pós Graduação em Sustentabilidade Ambiental na Amazônia (mestrado e doutorado) da Universidade Federal do Amazonas. Atua nas áreas de Psicologia Social do Ambiente, Educação Ambiental e Antropologia Social.

\section{MARY ANNE BARBOSA DE CARVALHO}

Possui graduação em Engenharia Agrícola e Ambiental pela Universidade Federal Rural do SemiÁrido (2012), com ênfase em Recursos Hídricos e Ambientais. Mestra em Ciências Florestais pela Escola Agrícola de Jundiaí, Universidade Federal do Rio Grande do Norte (2014), com ênfase em Manejo e Utilização dos Recursos Florestais. Doutoranda em Ciência do Solo pelo Centro de Ciências Agrárias, Campus II, Universidade Federal da Paraíba, com ênfase no manejo da matéria orgânica em solos tropicais e adubação orgânica, caracterização e uso agronômico de resíduos orgânicos; compostagem e sequestro e emissão de carbono em agroecossistemas.

\section{MICHELE PANTOJA DUQUE}

Graduanda em Ciências: Química e Biologia na Universidade Federal da Amazônia, Instituto de Ciências Exatas e Tecnologia (UFAM/ICET). Experiência em ações de extensão junto a escolas do ensino médio e a comunidade, com atividades envolvendo: gravidez na adolescência, fortalecimento do ensino da química na escola e sustentabilidade ambiental. Atualmente desenvolve pesquisa cientifica (bolsista PIBIC/CNPq) em biodiversidade, área zoologia de invertebrados, com ênfase em ácaros (Arthropoda: Acari) associados a plantas nativas e cultivadas na região do Médio Amazonas. 


\section{CARLOS HENRIQUE RODRIGUES GOMES}

Mestre em Educação para Ciências Ambientais pela Universidade Federal do Amazonas (UFAM); Especialista em Educação Ambiental com Ênfase na Diversidade pelo Instituto Federal de Educação Ciência e Tecnologia do Ceará (IFCE); Graduado em Pedagogia pela Universidade Estadual Vale do Acaraú (UVA); Licenciaturas Plenas em História e Geografia pela Universidade Estadual Vale do Acaraú (UVA); Docente de Geografia e História desde 1994. Docente de Geografia do quadro efetivo do Instituto Federal de Educação, Ciência e Tecnologia do Amazonas (IFAM).

\section{DELSINEI VIEIRA DA COSTA}

Mestrado no Ensino de Ciências ambientais, UFAM/USP,PROFCIAM; Especialista em Leitura e Produção de textos, pela Pontifícia Universidade Católica - MG; Graduação em Letras - Inglês pela Universidade Vale do Rio Verde de Três Corações (2006); Tem experiência na área de Letras, com ênfase em Línguas Estrangeiras Modernas; Professor EBTT - Lingua Inglesa do Instituto Federal de Ciências e Tecnologias do Amazonas.

\section{WILLIAM VIEIRA DE LIMA}

Graduado em Análise e Desenvolvimento de Sistemas pela Universidade do Estado do Amazonas (UEA, 2011); Especialista em Tecnologias Digitais para Sala de Aula (Unyleya, 2017); Mestre em Ensino de Ciências Ambientais (UFAM, 2018); Docente EBTT de Informática do INstituto Federal de Educação, Ciência e Tecnologia do Amazonas (IFAM/Campus Eirunepé).

\section{NATAFIA DEIZE NASCIMENTO PASSOS}

Técnica em Meio Ambiente pelo Instituto Federal de Educação, Ciência e Tecnologia da Bahia IFBA, traz no seu histórico profissional trabalhos sócio/ambiental em comunidades carentes, trabalhando a educação ambiental com oficinas e os 3Rs. Ingressou no serviço público municipal em 2017, na função de Técnica em meio ambiente, função que desenvolve até a presente data, ocupando-se com programas de educação ambiental, fiscalizações, licenciamento, monitoramento de recuperação de áreas degradadas, ênfase em busca de qualidade, respeito e melhoria para o meio ambiente.

\section{NELCINDA CLETO FERNANDES}

Bacharel em Estatística, com especialização em Gestão Ambiental com ênfase em Perícia e Auditoria e Mestre em Ciências e Meio Ambiente. Atualmente Chefe da Divisão de Monitoramento Ambiental da Secretaria Municipal de Meio Ambiente e Sustentabilidade- SEMMAS.

\section{ORLENO MARQUES DA SILVA JUNIOR}

Doutor em Planejamento Energético do Instituto Alberto Luiz Coimbra de Pós-graduação e Pesquisa de Engenharia (COPPE) - Universidade Federal do Rio de Janeiro. Mestre em geografia pela Universidade Federal do Pará, especialista em Geotecnologias (Sensoriamento Remoto e Geoprocessamento) pelo Instituto de Ensino Superior da Amazônia, graduado em Engenharia Ambiental pela Universidade do Estado do Pará e Técnico em Sensoriamento Remoto - Instituto Federal do Pará-IFPA. Atua na área análise de riscos ambientais, sensoriamento remoto, geoprocessamento e gestão ambiental.

\section{PAULA FERNANDA VIEGAS PINHEIRO}

Possui graduação em Engenharia Ambiental pela Universidade do Estado do Pará (2006) e mestrado em Geografia pela Universidade Federal do Pará (2010). Doutoranda no Programa de Pós Graduação em Biodiversidade e Biotecnologia - Rede BIONORTE. Atualmente é Docente na Universidade Federal Rural da Amazônia. Tem experiência em análises espaciais e gestão de Unidades de Conservação. Avaliação de Impacto Ambiental e Análise de Riscos Ambientais. Já elaborou diversos Planos de Gerenciamento de Resíduos Sólidos e Plano de Gestão Municipal de 
Resíduos Sólidos. Participa de grupos de pesquisas sobre Planejamento e Modelagem Ambiental na Amazônia. É Conselheira do Conselho Regional de Engenharia e Agronomia - CREA/PA e Perito Ambiental Judicial.

\section{PAULO S. M. MASCARENHAS}

Graduado em engenharia agronômica pela UFBA. Licenciado em Química pela UFSC. Especialização em Psicopedagogia Clínica e Institucional pela Faculdade Einstein, FACEI, Brasil. Mestre em Manejo e Conservação de Solos pela UFPB. Docente na Faculdade Independente do Nordeste - FAINOR, em Vitória da Conquista - BA

\section{PEDRO PAULO CONSUL KASSARDJIAN}

Engenheiro ambiental, graduado pela Escola Politécnica da USP em julho de 2016. Experiência em coordenação e desenvolvimento de projetos de engenharia sanitária, especialmente nas áreas de tratamento de água, esgoto e efluentes. Atualmente é engenheiro ambiental da Sharewater, onde atua como coordenador de projetos, execução, start up e operação de sistemas de tratamento. Experiência internacional de um ano na University of New South Wales, Austrália. Inglês avançado. Espanhol básico. Domínio do pacote Microsoft Office.

\section{PHILIPE SOUZA DA SILVA}

Técnico em Meio Ambiente (IFBA) Instituto Federal de Ciências e Tecnologia da Bahia. Atualmente, cursando 7aㅗ semestre de Engenharia Ambiental e Sanitária (UNIJORGE) Centro Universitário Jorge Amado.

\section{QUEMUEL ALVES DA SILVA}

Acadêmico do Curso de Pedagogia da Universidade do Estado do Amazonas - UEA. Coordenador do Departamento de Cultura da Secretaria Municipal de Educação do Município de Maraã/AM. Manaus, Amazonas, Brasil.

\section{RANIERI QUEIROZ DA COSTA}

Possui graduação em Gestão Pública pela Universidade do Estado do Amazonas (2014) e especialização em Gestão Pública pela Escola Superior Batista do Amazonas(2016). Acadêmico do curso de Ciências Contábeis da Universidade Federal do Amazonas. Tem experiência na área de Administração, com ênfase em Administração Pública.

\section{REGINA DE FÁTIMA PERALTA MUNIZ MOREIRA}

Possui graduação em Engenharia Química pela Universidade Estadual de Maringá (1982), mestrado em Química pela Universidade Federal de Santa Catarina (1987), doutorado em Química pela Universidade Federal de Santa Catarina (1994) e pós-doutorado na Universidade do Porto (1999). Atualmente é professor titular da Universidade Federal de Santa Catarina. Foi professora visitante na Universidade Federal de Minas Gerais $(2015,2015)$ e coordenadora do Comitê Assessor do CNPq da área de Engenharia Química.Tem experiência na área de Engenharia Química, com ênfase em Tratamentos e Aproveitamento de Rejeitos, atuando principalmente nos seguintes temas: tratamento de efluentes, adsorção, fotocatálise, processos oxidativos avançados.

\section{RENATO ALVES FERREIRA DE JESUS}

Bacharelado em Administração de Empresas (UNOPAR) Universidade Norte do Paraná. Técnico em Meio Ambiente (IFBA) Instituto Federal de Ciências e Tecnologia da Bahia. Atualmente, atua como Diretor Ambiental na Prefeitura Municipal de Várzea Nova - BA. Praça José Araújo S/N, Centro, Várzea Nova - BA. 


\section{RÍSSIA RIBEIRO DA SILVA}

É acadêmica do curso de Ciências Contábeis da Universidade Federal do Amazonas. Pesquisadora na área de Contabilidade.

\section{ROBERTO CARLOS FIGUEIREDO}

Mestre em Saúde, Sociedade Endemia Amazônia pela Universidade Federal do Amazonas, 2011 /2013. MBA Gestão Educacional e Docência do Ensino Básico e Superior pelo Instituto Carreira 2013 / 2014. MBA em Gerências Contábeis (Auditoria Controladoria e Pericia) pelo Instituto Brasileiro Pós graduação e Extensão (IBPEX), 2007/2008. Especialistas em Epidemiologia e Controle de Infecção Hospitalar pela Universidade Federal do Pará, 2008/2009, Enfermagem do Trabalho pelo (IBPEX), 2009/2010. Enfermagem Pediátrica e Neonatologia pela Escola Superior da Amazônia, 2011/2012. Gestão em Enfermagem pela Universidade Federal de São Paulo (UNIFESP), 2009/2010 MBA Gestão e Auditoria nos Serviço de Saúde Público pelo Instituto Carreira, $2011 / 2013$.

\section{RODRIGO CEREGATTI FRANCO}

Cientista Social, pesquisador em nível de Iniciação Científica, bolsista do Programa Institucional de Bolsas de Iniciação Científica (PIBIC) do CNPq (Conselho Nacional de Desenvolvimento Científico e Tecnológico). Pontifícia Universidade Católica de Campinas - PUC-Campinas.

\section{RONNY DA SILVA DUARTE}

Possui graduação em Física pela Universidade Estadual do Sudoeste da Bahia(2007). Tem experiência na área de Química.

\section{SAMARA BEATRIZ DA SILVA MENDONÇA ALVES}

Possui Graduação em Direito pela Universidade Paulista (2018). Experiência na área de Direito Ambiental e Direito Administrativo com ênfase em Saneamento Básico, Lei $n^{\circ}$ 11.445/07, Qualidade de Água e Licitações e Contratos Jurídicos

\section{SILVIA ELAINE MOREIRA}

É Mestra em Contabilidade e Controladoria pela Universidade Federal do Amazonas; Especialista em Auditorias Interna e Externa e Bacharel em Ciências Contábeis; Professora do Departamento de Ciências Contábeis da Universidade Federal do Amazonas e Pesquisadora nas áreas de Contabilidade, Controladoria e Gestão do Desenvolvimento Socioambiental.

\section{SIMONNY DO CARMO SIMÕES R. DE DEUS}

Doutora em Química com ênfase em Geotecnologias pela Universidade Federal do Pará/UFPA. Pesquisadora do Laboratório de Pesquisa em Meio Ambiente e Conservação LaPMAC/UFPA e do Laboratório de Simulação Computacional em Meio Ambiente LSCMAM/UFPA. Possuo Mestrado em Ciências e Meio Ambiente com ênfase em Modelagem Ambiental (2014), Especialização em Tecnologias Computacionais Aplicadas ao ensino de Ciências (2010) e graduação em Química (2008) pela Universidade Federal do Pará. Atualmente, participo de pesquisas em Modelagem Ambiental no LSCMAM e no Marine Environment \& Technology Center/MARETEC do Instituto Superior Técnico/IST da Universidade Técnica de Lisboa/UTL.r 


\section{SOLANGE BATISTA DAMASCENO}

Graduada em Ciências Biológicas (UNINORTE). Especialização e Desenvolvimento Sustentável da Amazônia (FSDB). Mestrado em Gestão e Regulação de Recursos Hídricos (UEA/PROFÁGUA). Conselheira Titular do Conselho Regional de Biologia de 6a Região (CRBIO-06). Conselheira Titular do Conselho Estadual de Recursos Hídricos do Amazonas (CERH/AM), Presidente do Comitê de Bacia Hidrográfica do Rio Tarumã-Açu (CBHTA), Consultora e Assessora Ambiental (BIOCAA).

\section{SUZIANE ARAÚJO AMORIM}

Estudante do curso de licenciatura em Química e Biologia pela Universidade Federal do Amazonas (UFAM), com conclusão prevista para 2019. Possui experiência da área de educação ambiental com atividades desenvolvidas com o público infantil. Atualmente atual como estagiária (bolsista IC/FAPEAM) na área de zoologia de invertebrados, com ênfase em ácaros (Arthropoda: Acari) associados a plantas cultivadas e nativas no estado do Amazonas.

\section{TÁCIO LUÍS DE ANDRADE CONCEIÇÃO}

Graduado em Engenharia Agronômica pela Universidade Estadual do Sudoeste da Bahia (1989); mestre em Ciências da Computação pela UFPE (2003). Doutorando em História das Ciências Agrárias pela UFBA e Professor efetivo do Instituto Federal da Bahia.

\section{THAÍS GLEICE MARTINS BRAGA}

Docente da Universidade Federal Rural da Amazônia - UFRA, Engenheira Ambiental e de Energias Renováveis - UFRA, mestrado em ciências ambientais - PPGCA/UFPA, doutoranda do programa de pós-graduação rede de biodiversidade e biotecnologia da Amazônia legal - BIONORTE/UFPA, atua no âmbito da física do clima, geotecnologias ( sensoriamento remoto, geoprocessamento, processamento digital de imagens, modelagem ambiental ), habilidades e competências em licenciamento ambiental urbano e rural ( plano de controle ambiental - PCA, plano de gerenciamento de resíduos sólidos - PGRS, licença prévia, de operação e instalação, atua em pericia ambiental, gestão ambiental, avaliação de impacto ambiental, avaliação de riscos ambientais, biodiversidade e biotecnologia.

\section{VALERIA BORGES DA SILVA}

Professora efetiva do Instituto Federal de Educação, Ciência e Tecnologia do Piauí - IFPI Campus Paulistana, onde ministra disciplinas do Eixo de Recursos Naturais. Possui graduação na Área de Ciências Agrárias, Mestre em Manejo de Solo e Água pela Universidade Federal da Paraíba - UFPB. Atualmente é Doutoranda do Programa de Pós Graduação Em Ciência do Solo da Universidade Federal da Paraíba - UFPB.

\section{VIVIANE MATTOS PASCOTTO}

Possui graduação em Ciências Biológicas (2005). Concluiu Aprimoramento em Análises Clínicas (2008), Mestrado em Patologia (2011) e Doutorado em Patologia (2015) pela Faculdade de Medicina de Botucatu- UNESP, com doutorado-sanduíche desenvolvido na Universidad Nacional del Litoral, Santa Fe Argentina . Tem experiência na área de Medicina com ênfase em Patologia, atuando principalmente nos seguintes temas: Patologia toxicológica, toxicologia da reprodução e desregulação endócrina. Atuou na Área Politica como Assessora de Agricultura e Meio Ambiente da prefeitura de São Manuel-SP. Atualmente é docente no Centro Universitário Sudoeste Paulista de Avaré. 


\section{WELSON GONÇALVES BARBOSA JUNIOR}

Formado em Comunicação Social pela FAAP-Fundação Armando Álvares Penteado, com especificação em Rádio e TV, onde se especializou em trabalhos comunitários relacionados ao meio ambiente. Especialização: MBA pela USP em Tecnologia da Qualidade. Atua desde 2006 como Gestor e membro da Comissão do programa Poli Recicla, onde implantou a Gestão de Resíduos da Escola Politécnica da USP. Organizador de Treinamentos para funcionários de laboratórios, equipes de apoio e administrativas da Escola Politécnica. Membro de comitês e comissões da USP relacionados a Gestão de Resíduos.

\section{YARA LAUREANO FRANCISCO}

Graduada em Biomedicina pelo no Centro Universitário Sudoeste Paulista, UniFSP. Possui trabalhos e projetos acadêmicos nas áreas de Imunologia, Patologia e Microbiologia e Análises Ambientais. 


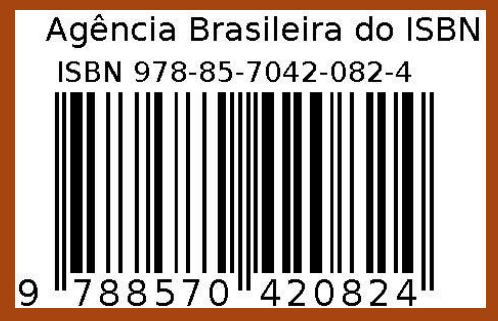

